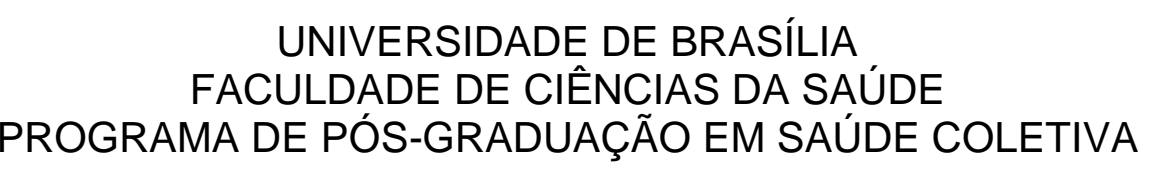

KIMIELLE CRISTINA SILVA

ACESSO ÀS FÓRMULAS NUTRICIONAIS PARA USUÁRIOS DO SUS:

PERCEPÇÕES DOS ATORES DO SISTEMA DE JUSTIÇA FRENTE À JUDICIALIZAÇÃO 
KIMIELLE CRISTINA SILVA

ACESSO ÀS FÓRMULAS NUTRICIONAIS PARA USUÁRIOS DO SUS:

PERCEPÇÕES DOS ATORES DO SISTEMA DE JUSTIÇA FRENTE À JUDICIALIZAÇÃO

Dissertação apresentada como requisito para a obtenção do título de Mestre em Saúde Coletiva do Programa de Pós-Graduação em Saúde Coletiva da Universidade de Brasília - Mestrado Profissionalizante.

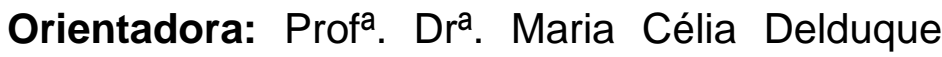
Nogueira Pires de Sá 
KIMIELLE CRISTINA SILVA

\section{ACESSO ÀS FÓRMULAS NUTRICIONAIS PARA USUÁRIOS DO SUS: \\ PERCEPÇÕES DOS ATORES DO SISTEMA DE JUSTIÇA FRENTE À JUDICIALIZAÇÃO}

Dissertação apresentada como requisito para a obtenção do título de Mestre em Saúde Coletiva do Programa de Pós-Graduação em Saúde Coletiva da Universidade de Brasília - Mestrado Profissionalizante.

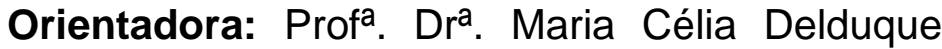
Nogueira Pires de Sá.

Aprovada em: 27 de abril de 2016

\section{BANCA EXAMINADORA}

Prof. ${ }^{\text {D }}$ Dr. ${ }^{a}$ Maria Célia Delduque Nogueira Pires de Sá Presidente

Prof. ${ }^{\text {a }}$ Dr. ${ }^{\text {a }}$ Silvia Badim Marques

Examinadora Externa

Prof. ${ }^{\text {a }}$ Dr. ${ }^{\text {a }}$ Inês Rugani Ribeiro de Castro

Examinadora Externa

Prof. ${ }^{a}$ Dr. ${ }^{\text {a }}$ Ana Valéria Machado Mendonça

Examinadora Suplente 
A minha vó, Laura, por todos os momentos em que rimos e choramos a imcompreensão dos obstáculos que surgiam. Que as lágrimas de saudade tragam também a sabedoria de compreender os designios desta nossa vida.

A minha mãe, Eliane (Lili), prova da grandeza do amor que transpõe tempo e espaço. 


\section{AGRADECIMENTOS}

A Deus, aos Amigos Espirituais e à minha amada vó Laura que me deram força, coragem e resignação para chegar até o fim. Quantas vezes minhas orações feitas a vocês abrandaram o meu coração.

À minha orientadora Prof ${ }^{a}$. Dra . Maria Célia Delduque que acreditou e apostou na minha ideia desde o começo e que com sua experiência, visão crítica e conhecimento instigava-me e desafiava a cada dia, despertando em mim a vontade de fazer sempre o melhor.

À Silvia Badim pelos encontros no Sebinho para ajuda no uso do Qualiquantisoft e, também, pela disponibilidade em participar da minha banca. Agradeço também à Inês Rugani pelo carinho em aceitar a fazer parte da minha banca.

À minha "ex chefe" e amiga Janete pelo carinho e profissionalismo que levo para toda minha vida.

Aos ex e atuais colegas da Secretaria Municipal de Saúde de Belo Horizonte, exemplos de gestão do SUS que me orgulha: Angeliquinha, Dra - Susana, Márcia Parizzi, Ana Pitchon, Luzia, Janete, Soninha Gesteira, Sheila, Claudinha, Dr. Helvécio.

Aos colegas de trabalho da CGAN/DAB: Carol Lucena, Tati, Bruna, Lorena, Ana Luisa, Sarah, Eduardo e Renata pelo apoio e carinho e aos atuais colegas da CGGAB/DAB: Marcelo Pedra, Alyne, Kátia, Lari, Olivia, Mônica, Cris, Fábio, Rosana, Marcinha, Mônica, Webster, Mélquia que fazem meus dias mais "leves". E ao Dirceu pela oportunidade de trabalhar com o que gosto e acredito! Gratidão!

Aos meus colegas de mestrado: Ari, Dani, Carol e Patrícia pela força e cumplicidade.

Agradeço enormemente à Patricia Jaime pela oportunidade e confiança junto à sua gestão na CGAN/DAB na agenda das "necessidades alimentares especiais" e que por ser uma agenda de muitas lacunas e desafios inquietou-me em realizar esse trabalho. Grata! 
À minha amigona, Roberta, que longe e perto sempre me faz feliz! À Ana Paula Bortoleto pela ajuda e disponibilidade nos temas de conflito de interesse. À Jana, mesmo não estando nem aí para mim, amo muito!

À minha família de Brasilia: Mara, Renata, Lorena e Vivi pelo companheirismo. Obrigada por tudo!

À Juliana Casemiro pela disponibilidade em ler meu trabalho e dar uma luz para o que faltava. À Kelly pela leitura cuidadosa e pela "coorientação". E à Nágila, um anjinho que ajudou muito na normatização desse trabalho. Valeu!

À minha amiga-irmã, Carol, por sempre me ouvir, falar o que deve e o que não deve, pela sintonia, rir das minhas piadas e, agora, por disponibilizar sua casa no Rio de Janeiro. Adoro-te demais!

Aos meus colegas do NASF de Belo Horizonte por permitir a rica experiência de estar com vocês e aprender diversas formas de cuidado.

Aos entrevistados do Sistema de Justiça em que tive o prazer de conhecer o trabalho e que me receberam com muito carinho. Obrigada!

Aos trabalhadores e gestores do SUS que diariamente produzem saúde e saber, mas que também enfrentam grandes desafios nos seus cotidianos. 
"Todas as formas de governo caem diante da necessidade por pão. Para o homem com sua família faminta, o pão passa em primeiro lugar - antes de seu sindicato, de sua pátria, de sua religião".

(John L. Lewis, líder trabalhista dos EUA) 


\section{RESUMO}

Introdução: A saúde e a alimentação são considerados direitos sociais pela Constituição e a solicitação de fórmulas nutricionais por meio de ações judiciais contra as três esferas de gestão tem aumentado, constituindo-se como um problema para o Poder Público. Objetivo: Conhecer e analisar as percepções do Sistema de Justiça sobre a judicialização do acesso às formulas nutricionais no Sistema Único de Saúde. Métodos: Foi utilizada a abordagem quali-quantitativa, de caráter exploratório e descritivo, com realização de entrevista semiestruturada com representantes do Sistema de Justiça. Utilizou-se a técnica do Discurso do Sujeito Coletivo para a análise dos dados. Resultados e discussão: A partir da análise dos discursos foi possível perceber que o Sistema de Justiça reconhece o direito à alimentação na Constituição e a sua efetivação é realizada por meio de políticas públicas que garantem alimentos, demonstrando uma percepção reduzida sobre as políticas de alimentação e nutrição; o conceito de Segurança Alimentar e Nutricional (SAN) está distante do processo de trabalho, principalmente dos magistrados; o direito à alimentação deve ser executado de forma diferente no campo da SAN e na saúde; para a garantia do direito à alimentação são necessárias ações intersetoriais, mas os advogados, defensores e promotores, julgam esses pleitos como direito à saúde; incompreensão sobre à análise técnica das fórmulas nutricionais, comparando-as com medicamentos; o lobby do mercado e da indústria é a razão mais relevante para a judicialização da saúde; diálogos institucionais são a estratégia mais precisa para o enfrentamento da judicialização. Considerações Finais: É necessário que o Sistema de Justiça seja inserido na discussão da SAN e do Direito Humano à Alimentação Adequada, seja por meio do Conselho Nacional de Segurança Alimentar e Nutricional ou das Câmaras Intersetoriais de Segurança Alimentar e Nutricional, de forma a discutir o papel do Sistema Único de Saúde na garantia desses produtos alimentícios.

Palavras-chave: Direito à saúde; Direito à alimentação; Judicialização; Políticas de alimentação e nutrição. 


\begin{abstract}
Introduction: Health and nutrition are considered social rights by the Brazilian Constitution. The request for nutritional formulas through lawsuits against the three levels of government has increased, establishing itself as a State problem. Objectives: This study aims to understand and analyze the perceptions of the justice system on the judicialization of the access to nutritional formulas in the Public Health System. Methods: For this, we used a quali-quantitative methodology with an exploratory and descriptive approach. We conducted semi-structured interviews with representatives of the justice system. For the data analysis, we used the technique of the "Collective Subject Discourse". Results and discussion: Based on the analysis of the discourses, it was revealed that the Justice System: recognizes the right to food in the Constitution, but its enforcement is carried out by public policies that guarantee food, demonstrating a reduced perception of the policies on food and nutrition. The concept of Food and Nutritional Security (SAN) is distant from their work process, especially the magistrates. The right to food should be guaranteed differently in the field of SAN and health; to guarantee the right to food intersectoral actions are required, but the lawyers, public defenders and prosecutors strategically judge these claims as a right to health. There is inconsistency on the technical analysis of the legal processes requesting drugs and those requesting nutritional formulas. The lobby of the market and the industry is the most important reason for the judicialization of health and the institutional dialogue is the more accurate strategy to face the problem. Final considerations: It is necessary that the justice system is inserted in the discussion of SAN and the Human Right to Adequate Food, either through the National Council for Food and Nutrition Security or the Food and Nutrition Security Intersectoral Chambers in order to discuss the role of the Public Health System in ensuring these food products.
\end{abstract}

Keywords: Right to Health; Right to food; Judicialization; Food and nutrition policies. 


\section{LISTA DE FIGURAS}

Figura 1 - Incidência das Ideias Centrais: pergunta $n^{0} 1 \ldots \ldots \ldots \ldots \ldots \ldots \ldots \ldots \ldots \ldots \ldots \ldots \ldots . . . .55$

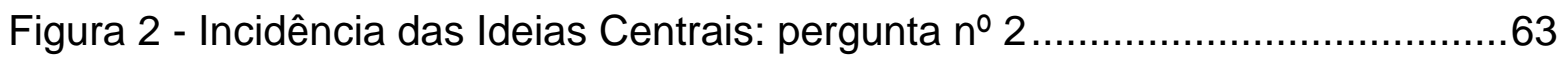

Figura 3 - Incidência das Ideias Centrais: pergunta $n^{\circ} 3 \ldots \ldots \ldots \ldots \ldots \ldots \ldots \ldots \ldots \ldots \ldots \ldots \ldots . . .68$

Figura 4 - Incidência das Ideias Centrais: pergunta $n^{0} 4 \ldots \ldots \ldots \ldots \ldots \ldots \ldots \ldots \ldots \ldots \ldots \ldots \ldots . . .73$

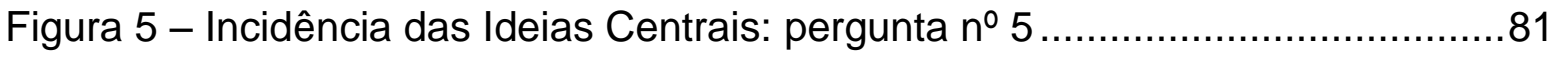




\section{LISTA DE TABELAS}

Tabela 1 - Caracterização dos sujeitos, Brasília, 2016 53 


\section{LISTA DE QUADROS}

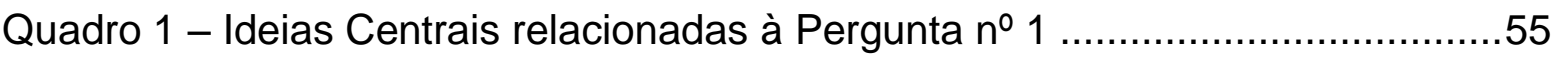

Quadro 2 - Ideias Centrais relacionadas à Pergunta ํo 2 ….................................63

Quadro 3 - Ideias Centrais relacionadas à Pergunta ํo 3 .....................................68

Quadro 4 - Ideias Centrais relacionadas à Pergunta ํo 4 ….................................73

Quadro 5 - Ideias Centrais relacionadas à Pergunta ํㅡ 5 .....................................80 


\section{LISTA DE ABREVIATURAS E SIGLAS}

\begin{tabular}{|c|c|}
\hline AC & Ancoragens \\
\hline ADCT & Ato das Disposições Constitucionais Transitórias \\
\hline AGU & Advocacia-Geral da União \\
\hline ANVISA & Agência Nacional de Vigilância Sanitária \\
\hline CAISAN & Câmara Intersetorial de Segurança Alimentar e Nutricional \\
\hline CDESC & Comitê de Direitos Econômicos, Sociais e Culturais \\
\hline CEAF & Componente Especializado da Assistência Farmacêutica \\
\hline CF & Constituição Federal \\
\hline CGAN & Coordenção-Geral de Alimentação e Nutrição \\
\hline CNJ & Conselho Nacional de Justiça \\
\hline CNSAN & Conferência Nacional de Segurança Alimentar e Nutricional \\
\hline CONITEC & Comissão Nacional de Incorporação de Tecnologias \\
\hline CONSEA & Conselho Nacional de Segurança Alimentar e Nutricional \\
\hline DAB & Departamento de Atenção Básica \\
\hline DHAA & Direito Humano à Alimentação Adequada \\
\hline DSC & Discurso do Sujeito Coletivo \\
\hline EC & Emenda Constitucional \\
\hline E-Ch & Expressão Chave \\
\hline ECOSOC & Conselho Econômico e Social \\
\hline FAO & Food and Agriculture Organization \\
\hline FioCruz & Fundação Oswaldo Cruz \\
\hline IBFAN & International Baby Food Ection Network \\
\hline IC & Ideia Central \\
\hline LOAS & Lei Orgânica da Assistência Social \\
\hline LOSAN & Lei Orgânica de Segurança Alimentar e Nutricional \\
\hline MDS & Ministério do Desenvolvimento Social \\
\hline MP & Ministério Público \\
\hline MS & Ministério da Saúde \\
\hline NAT & Núcleos de Assessoramento Técnico \\
\hline OMS & Organização Mundial da Saúde \\
\hline PCDT & Protocolo Clínico e Diretrizes Terapêuticas \\
\hline Phe & Fenilalanina \\
\hline $\begin{array}{l}\text { PIDESC } \\
\text { PKU }\end{array}$ & $\begin{array}{l}\text { Pacto Internacional sobre os Direitos Econômicos, Sociais e Culturais } \\
\text { Fenilcetonúria }\end{array}$ \\
\hline PLANSAN & Plano Nacional de Segurança Alimentar e Nutricional \\
\hline PNAN & Política Nacional de Alimentação e Nutrição \\
\hline PNSAN & Política Nacional de Segurança Alimentar e Nutricional \\
\hline PNTN & Programa Nacional de Triagem Neonatal \\
\hline PPA & Plano Plurianual \\
\hline PRODISA & Programa de Direito Sanitário \\
\hline RENAME & Relação Nacional de Medicamentos \\
\hline SAN & Segurança Alimentar e Nutricional \\
\hline SISAN & Sistema Nacional de Segurança Alimentar e Nutricional \\
\hline SUAS & Sistema Único de Assistência Social \\
\hline
\end{tabular}


SUN Scaling Up Nutrition

SUS Sistema Único de Saúde

TAC Termo de Ajustamento de Conduta

TCLE Termo de Consentimento Livre e Esclarecido

UBS Unidade Básica de Saúde

UnB Universidade de Brasília

UTI Unidade de Terapia Intensiva 


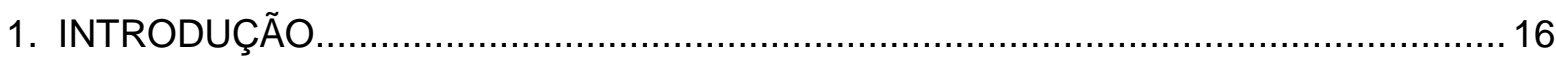

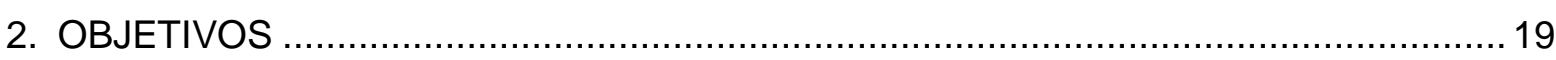

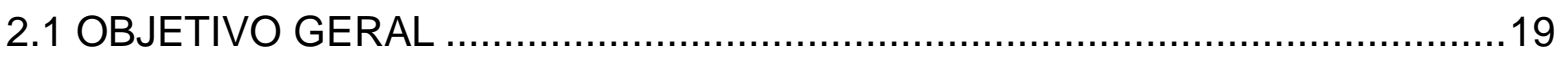

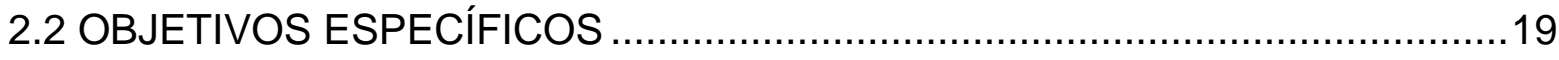

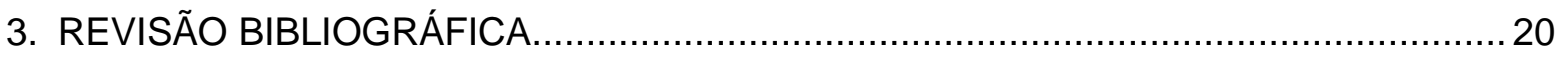

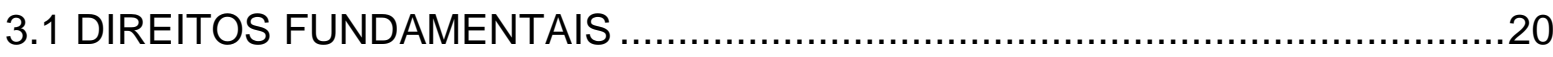

3.1.1 Histórico dos Direitos Fundamentais ….............................................20

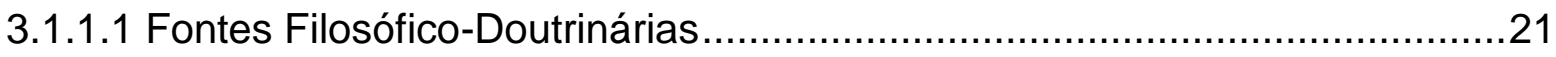

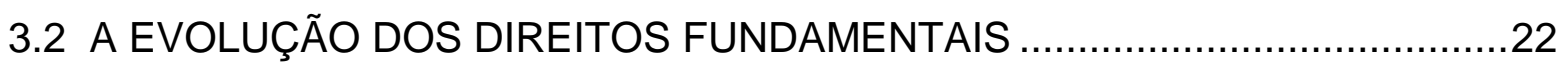

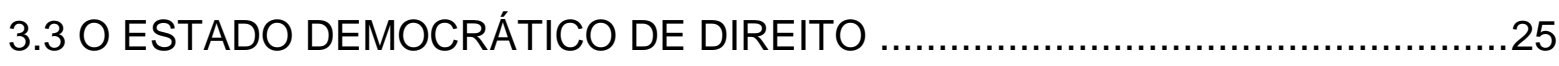

3.3.1 Evolução do Estado Democrático de Direito ……...................................25

3.4 EVOLUÇÃO CONSTITUCIONAL BRASILEIRA E OS DIREITOS SOCIAIS

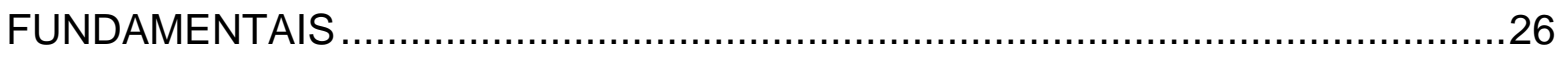

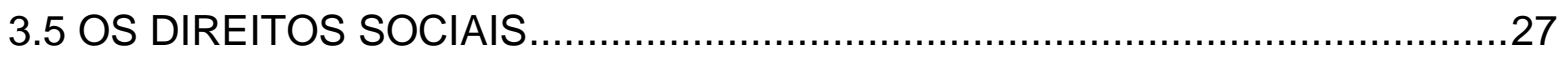

3.5.1 Os Direitos Sociais na Constituição de 1988 .....................................27

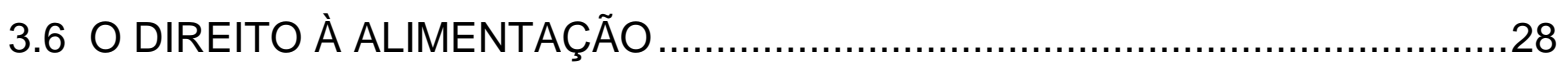

3.6.1 O Direito à Alimentação no Contexto Internacional ................................28

3.6.2 O Direito à Alimentação no Contexto Nacional .......................................32

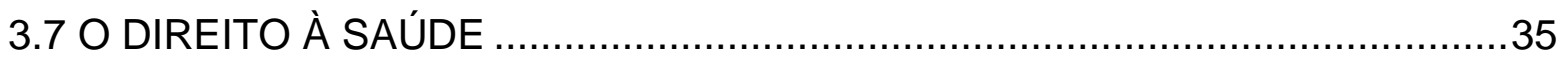

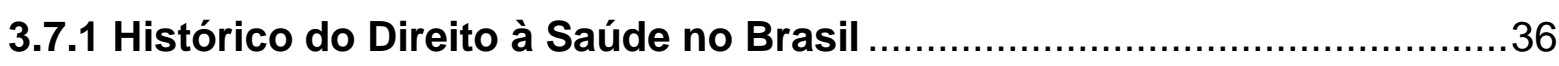

3.7.1.1 Carta Magna de 1988: Garantia da Saúde como Direito Fundamental.......38

3.8 A JUDICIALIZAÇÃO DAS POLITICAS PÚBLICAS …...................................40

3.8.1 A Judicialização do Direito à Alimentação.............................................41

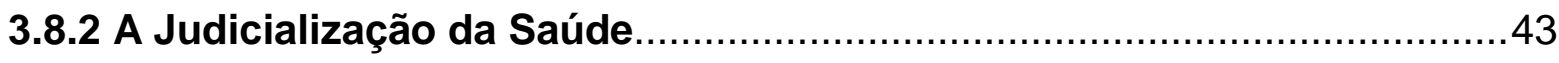

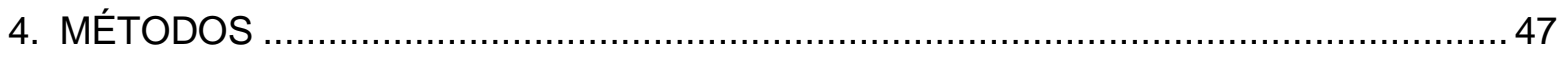

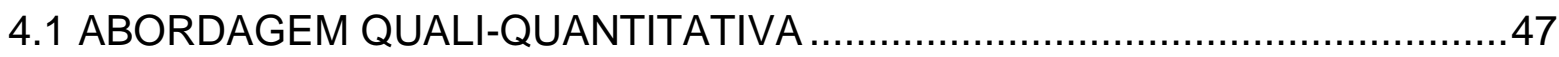


4.1.1 Pesquisa Exploratória

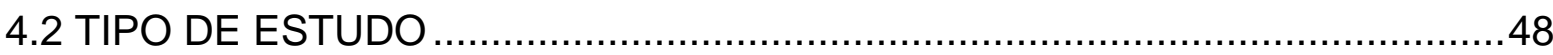

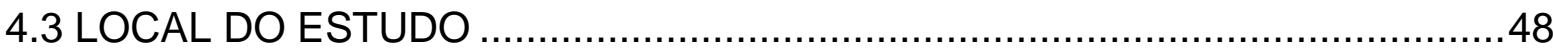

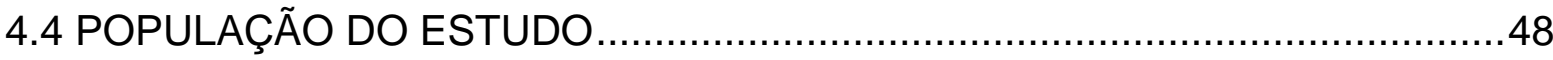

4.5 INSTRUMENTO DE COLETA DE DADOS …………............................................ 49

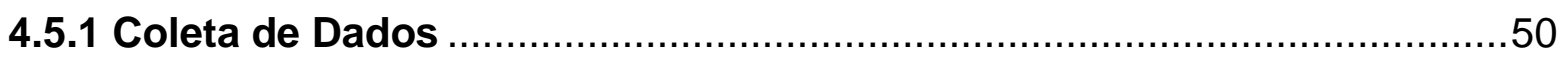

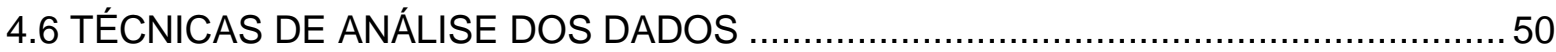

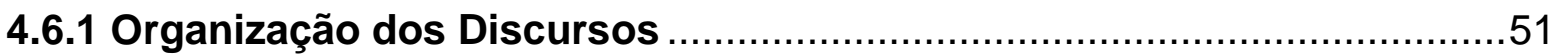

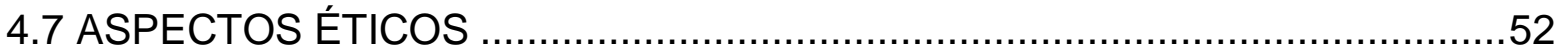

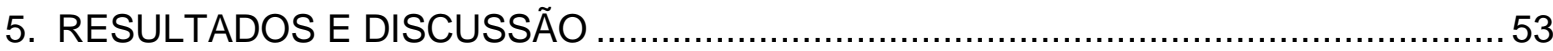

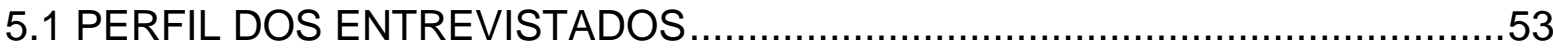

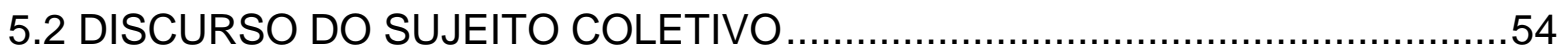

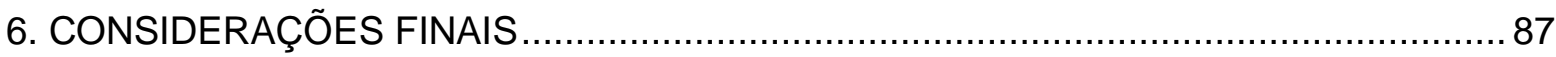

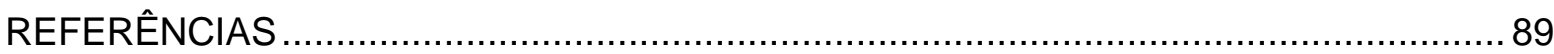

APÊNDICES

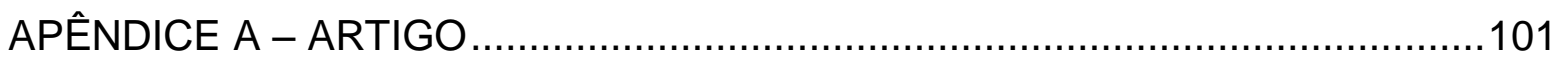

APÊNDICE B - ROTEIRO SEMIESTRUTURADO PARA ENTREVISTAS.............123

APÊNDICE C- TERMO DE CONSENTIMENTO LIVRE E ESCLARECIDO .........124

APÊNDICE D- PARECER CONSUBSTANCIADO DO COMITÊ DE ÉTICA E

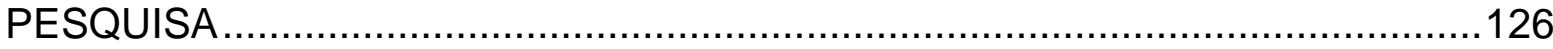

APÊNDICE E- RESUMOS E IDEIAS: PERGUNTA № 1 …................................131

APÊNDICE F- RESUMOS E IDEIAS: PERGUNTA № 2 ….................................140

APÊNDICE G- RESUMOS E IDEIAS: PERGUNTA № $3 \ldots \ldots \ldots \ldots \ldots \ldots \ldots \ldots \ldots \ldots . . . . . . . . . . . . . . . . . . . .147$

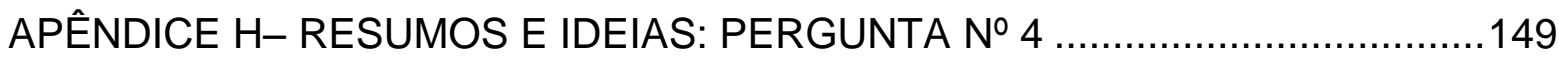

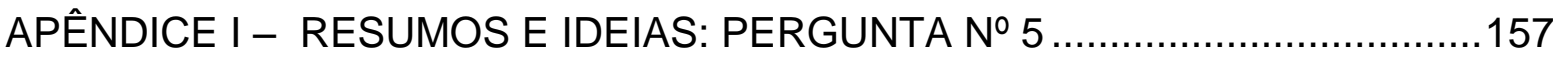




\section{INTRODUÇÃO}

No Brasil, as demandas judiciais relacionadas a procedimentos, insumos e assistência à saúde contra entes públicos cresceram exponencialmente nos últimos dez anos. Esse fenômeno, denominado judicialização da saúde, envolve aspectos políticos, sociais, éticos e sanitários que vão além do componente jurídico e de gestão de serviços públicos, produzindo alterações significativas nas relações sociais e institucionais (VENTURA et al, 2010, p. 96).

Tal fato vai de encontro à democratização dos direitos humanos e sociais, em que uma sociedade excludente e estratificada cujo padrão de proteção social privilegie apenas alguns grupos, caminhe para um modelo de proteção social inclusiva e igualitária (FLEURY e FARIA, 2014, p. 99).

A incorporação do direito à saúde na Constituição Federal (CF) brasileira de 1988 como um direito social fundamental, situando-se ao lado do da educação, do trabalho, da moradia, da segurança, foi um marco na democratização dos direitos sociais no Brasil. Além de se constituir como instrumento legal capaz de assegurar que os direitos fundamentais sejam concretizados.

O Direito Humano à Alimentação Adequada (DHAA) é indispensável para a sobrevivência. As normas internacionais reconhecem 0 direito de todos à alimentação adequada e o direito fundamental de toda pessoa a estar livre da fome. No Brasil, desde 2010, este direito está assegurado entre os direitos sociais da Constituição Federal, com a aprovação da Emenda Constitucional (EC) ํㅜ 64, de 2010 (ABRANDH, 2013).

O direito à alimentação é, em uma das suas dimensões, o combate à fome, observando a quantidade regular e permanente de alimentos para à manutenção das necessidades essenciais, a qualidade nutricional, além do respeito à realidade cultural, social e econômica. Nesse sentido, a alimentação extrapola sua faceta meramente química e física. Assim, o processo de alimentação de qualidade, em todos os seus aspectos e dimensões, garante qualidade de vida (VALENTE, 2002, p. 38-39). 
Como a saúde e a alimentação são consideradas direitos sociais pela Constituição Federal, a solicitação de fórmulas nutricionais e alimentos por meio de ações judiciais contra as três esferas de gestão do Sistema Único de Saúde (SUS) tem crescido, constituindo-se como um problema para o Poder Público. A necessidade de financiamento e a elaboração de protocolos, diretrizes terapêuticas e fluxos são demandas recorrentes em diversos espaços de pactuação e congressos regionais e nacionais que contam com a presença dos gestores (CONASEMS, 2013).

Alguns indivíduos com necessidades alimentares especiais alimentam-se por uma via alternativa, geralmente sondas nasoentéricas, nasogástricas e gastrostomias, e necessitam de fórmulas para nutrição enteral. Essas fórmulas são definidas pela Agência Nacional de Vigilância Sanitária (ANVISA), como:

\begin{abstract}
Alimento para fins especiais industrializado apto para uso por tubo e, opcionalmente, por via oral, consumido somente sob orientação médica ou de nutricionista, especialmente processado ou elaborado para ser utilizado de forma exclusiva ou complementar na alimentação de pacientes com capacidade limitada de ingerir, digerir, absorver ou metabolizar alimentos convencionais ou de pacientes que possuem necessidades nutricionais específicas determinadas por sua condição clínica (BRASIL, 2015).
\end{abstract}

Além das fórmulas para nutrição enteral, há as fórmulas infantis para necessidades dietoterápicas especificas, definidas como:

Aquelas cuja composição foi alterada com 0 objetivo de atender às necessidades específicas decorrentes de alterações fisiológicas e/ou patológicas temporárias ou permanentes (BRASIL, 2011).

Essas fórmulas para nutrição são fabricadas por grandes indústrias farmacêuticas e alimentícias multinacionais e possuem custo elevado para compra. Segundo Ferreira (2009), o consumo de 2 litros de fórmula para nutrição enteral líquida acarreta em um custo mensal de 3 salários mínimos.

Essas fórmulas são geralmente de alto custo e, até o presente momento, não possuem financiamento específico no SUS, exceto no âmbito hospitalar e no caso daquelas destinadas aos indivíduos com fenilcetonúria (BRASIL, 2009; BRASIL, 2012; BRASIL, 2013). Mesmo sem o financiamento e a obrigatoriedade de oferta, algumas Unidades da Federação e municípios possuem uma rede assistencial para acompanhamento de indivíduos com necessidades alimentares especiais, contando 
com protocolos, fluxos e diretrizes clínicas, normatizando o fornecimento de fórmulas nutricionais industrializadas (FINK et al, 2010).

Este tema tem sido objeto das minhas inquietações desde julho de 2012, ano no qual ingressei como consultora técnica da Coordenação-Geral de Alimentação e Nutrição do Departamento de Atenção Básica do Ministério da Saúde (CGAN/DAB/MS), trabalhando especificamente com a pauta das necessidades alimentares especiais, quando pude vivenciar as lacunas políticas, técnicas e ideológicas relacionadas às formulas nutricionais no âmbito do SUS. Pude também perceber que apenas a resposta técnica aos processos não produzia nenhuma mudança na relação entre os dois sistemas: saúde e justiça.

Enquanto sujeito implicada neste processo, reafirmo minha entrada em cena como um ser político e dirigente dessa agenda. E, nesse caso, autora de uma dissertação que me provoca a ficar cada vez mais inquieta na busca de caminhos possíveis ao enfrentamento da questão em estudo. Logo, o encontro entre o mundo teórico e o real me faz sentir esse embricamento e indissociação entre o sujeito político e sua prática militante, que atua no âmbito da gestão, e o sujeito epistêmico que busca o conhecimento e a investigação, embora um opere sobre o outro por meio da busca de saberes que fundamentem uma práxis. Segundo Minayo (2006, p. 42), toda investigação social deve contemplar uma característica básica do seu objeto, o aspecto qualitativo e, também, a implicação do sujeito no estudo.

Assim, pretende-se, com esta dissertação, analisar as percepções do Sistema de Justiça sobre a judicialização do acesso às fórmulas nutricionais no SUS e que seus achados possam contribuir para o conhecimento científico, técnico e social, para a gestão no âmbito do SUS e guiar a construção de ferramentas efetivas e eficazes para a concretização do Direito à Saúde e do Direito à Alimentação. 


\section{OBJETIVOS}

\subsection{OBJETIVO GERAL}

- Conhecer e analisar as percepções dos atores do Sistema de Justiça sobre a judicialização do acesso às formulas nutricionais no Sistema Único de Saúde (SUS).

\subsection{OBJETIVOS ESPECÍFICOS}

- Conhecer as percepções do Sistema de Justiça sobre o direito à alimentação, e o papel do Poder Executivo na efetivação desse direito;

- Conhecer a percepção do Sistema de Justiça quanto ao assessoramento técnico na área de saúde para análise dos processos judiciais que demandam fórmulas nutricionais;

- Conhecer a percepção do Sistema de Justiça quanto às análises técnicas dos processos judiciais sobre fórmulas nutricionais e medicamentos;

- Conhecer a percepção do Sistema de Justiça sobre as possíveis causas da judicialização para o acesso às fórmulas nutricionais no SUS;

- Conhecer a percepção do Sistema de Justiça sobre o seu papel na resolução dos problemas relacionados à judicialização para o acesso às fórmulas nutricionais. 


\section{REVISÃO BIBLIOGRÁFICA}

\subsection{DIREITOS FUNDAMENTAIS}

Os direitos fundamentais são considerados essenciais à pessoa humana, necessários para uma existência digna, livre e igualitária. Tais direitos concretizaram-se sistemática e normativamente na passagem do Estado Liberal para o Estado de Bem-Estar Social no início do século XX (MORAES, 2003).

É importante destacar que nem sempre os direitos fundamentais foram considerados relevantes. A evolução histórica desses direitos provocou a compreensão coletiva para alcance da dignidade humana e possibilitou a sua consolidação na Constituição brasileira.

\subsubsection{Histórico dos Direitos Fundamentais}

A garantia dos direitos fundamentais foi assegurada por meio de instrumentos e mecanismos históricos que possibilitaram normas de caráter público, capazes de se manifestar em condições para desenvolver ações efetivas.

Na segunda metade da Idade Média, há o reconhecimento do registro de direitos em documentos. Na Europa, os registros de direitos de comunidades locais e corporações de senhores feudais concediam direitos próprios e específicos aos membros de grupos, por meio de cartas de franquia e forais, para que fossem respeitados e conhecidos por todos (SILVA, 2000, p.155).

Embora existindo instrumentos de defesa do indivíduo desde a Antiguidade, o marco histórico das declarações dos direitos fundamentais deu-se com a Magna Carta Inglesa, registrada em 15 de junho de 1215, na Inglaterra, por João SemTerra, a qual garantia privilégios a todos os súditos da monarquia, elencando garantias no caso de violação e limitando o poder do rei. Tal documento assegurava a liberdade de ir e vir; a propriedade privada; a exigência de pena de acordo com o delito e o julgamento na forma da lei. Esse e outros documentos, bem como a legislação inglesa, conceberam o rule of law ${ }^{1}$, ou seja, a submissão de todos ao

\footnotetext{
${ }^{1}$ O rule of law é uma expressão do Common Law, que inclui o direito judiciário inglês. Foi desenvolvido no século XII quando as cortes reais passaram a estabelecer o direito consuetudinário, dando origem ao law of de land (FERREIRA FILHO, 2009, p. 11).
} 
Império do direito que se desenvolveu a partir do século XII (FERREIRA FILHO, 2009).

\subsubsection{Fontes Filosófico-Doutrinárias}

A existência de um direito superior concedido aos homens pelos deuses era marcante na Antiguidade. A compreensão de um direito não resultante da vontade humana prevaleceu durante a Idade Média até o final do século XVIII (SABADELL, 2002, p. 21).

A suma teológica de Tomás de Aquino no século XIII demostrava uma hierarquia de leis. Nessa hierarquia, a lei suprema é a lei concedida por Deus, abaixo está a lei divina (anunciada por Deus ou declarada pela Igreja), lado a lado está a lei natural inerente ao homem e manifestada pela razão e abaixo de todas está a lei humana, editada pelo legislador (BANDERA, 1993, p. 638).

A doutrina do pensamento iluminista foi concebida pela Escola do Direito Natural e das Gentes. Hugo Grócio, fundador do jusnaturalismo, compreendia que determinados direitos procederam da natureza humana e não são delegados e idealizados pelo legislador, são identificados pela razão (FERREIRA FILHO, 2009).

O termo "direitos fundamentais" originou-se na França ${ }^{2}$ em 1770. A partir de então, instituiu-se a relação jurídica entre cidadãos e Estado, em termos de direitos e garantias individuais. Assim, foi estabelecido que os direitos fundamentais são aqueles assegurados no texto constitucional dos Estados (LEAL, 2009, p. 28).

Já no final do século XVII é instituída a primeira geração (ou dimensão ${ }^{3}$ ) dos direitos fundamentais: as liberdades públicas ${ }^{4}$. A segunda geração desses direitos

\footnotetext{
${ }^{2}$ A França vivia sobre a égide do movimento político que conduziu à Revolução de 1789.

${ }^{3}$ Alguns doutrinadores têm dissentido a respeito da terminologia mais correta para se denominar o evento de evolução histórica dos direitos fundamentais, e isto acontece principalmente entre as expressões gerações e dimensões. Paulo Bonavides faz referência expressa ao termo gerações dos direitos fundamentais para explicar a inserção histórica deles nas constituições dos países, sendo este posicionamento seguido por vários outros constitucionalistas. Para Bonavides: "os direitos fundamentais passaram na ordem institucional a manifestar-se em três gerações sucessivas, que traduzem sem dúvida um processo cumulativo e quantitativo". Ressalta-se que parte dos doutrinadores têm se levantado contra o posicionamento acima firmado, uma vez que, para eles, o termo "gerações" é impróprio para definir esta evolução dos direitos fundamentais. Fundamentam seus argumentos no fato de que o termo gerações poderia desencadear a falsa idéia no seguinte sentido: conforme fossem evoluindo, ocorreria uma substituição de uma geração por outra, o que como sabemos, jamais poderá acontecer. Tal posicionamento doutrinário defende que o mais correto
} 
surgiu após a Primeira Guerra Mundial: os chamados direitos sociais. Já a terceira geração é a dos direitos da solidariedade (BOBBIO, 2004; FERREIRA FILHO, 2009).

No final do século XVIII desponta o Estado Contemporâneo com o propósito de coibir a autoridade dos governantes. Os direitos fundamentais, por sua vez, vêm constituir limitação e associação com o poder do Estado. É a baliza entre o que o Estado pode ou não fazer (SPARAPANI, 2012).

\subsection{A EVOLUÇÃO DOS DIREITOS FUNDAMENTAIS}

No século XVIII, a ideologia dos Direitos do Homem foi base para a reformulação das instituições políticas. O processo de desenvolvimento da sociedade e o Estado de Direito (ressalta-se que os direitos fundamentais precedem a este) induziram a precaução com a proteção dos indivíduos e do meio que vivem gerando normativas que consagraram direitos comuns aos homens, chamados de direitos fundamentais (BOBBIO, 2004, p. 93).

A expressão "direitos fundamentais" possui vários sinônimos, dentre eles os termos liberdades públicas, direitos humanos e direitos subjetivos públicos. Ainda assim, a expressão "direitos fundamentais" é a mais clara pela sua abrangência, pois o termo "direito" indica tanto a situação em que se deseja a defesa do cidadão perante o Estado como os interesses jurídicos de caráter social, político ou difuso, protegidos pela Constituição. E o termo "fundamental" destaca a precisão desses direitos à condição humana (ARAUJO, 2001, p. 109-110).

Observa-se que há autores que utilizam a expressão "direito do homem", mas a nomenclatura mais adequada é direitos humanos, direitos humanos fundamentais ou direitos fundamentais ${ }^{5}$ (FERREIRA FILHO, 2009).

seria a expressão "dimensão", e não geração, pelos motivos acima detalhados. BONAVIDES, 2006, p. 563).

4 Expressão instituída aos direitos declarados em 1789, na Declaração dos Direitos do Homem e do Cidadão e em outras declarações de principio liberal, todavia é pouco adequada num ambiente que reconhece entre as prerrogativas de direitos no plano econômico e social que vão mais longe que meras liberdades. Ainda modernamente é empregada como sinônimo de direitos fundamentais. FERREIRA FILHO, 2009).

${ }^{5}$ No Brasil, a terminologia utilizada nas constituições foi alternada entre direitos e garantias individuais, direitos e garantias fundamentais e direitos fundamentais do homem. Na Constituição Federal de 1988 refere-se, no titulo II, direitos e garantias fundamentais, cujo Capítulo I enuncia 
Apesar de algumas pessoas retratarem as diferenças entre direitos humanos e direitos fundamentais, percebe-se que, em muitos conceitos e teorias, são utilizadas de forma semelhantes. Alguns afirmam que existe um ponto em comum entre os direitos humanos e os direitos fundamentais no aspecto material, ou seja, os dois reconhecem os valores de liberdade e igualdade e pretendem proteger e promover a dignidade da pessoa humana, mas divergem no aspecto formal, que se refere a sua posição dentro da ordem jurídica. Quando são reconhecidos no direito interno denominam-se direitos fundamentais e, quando legitimados em tratados internacionais (no direito internacional), denominam-se direitos humanos (OLIVEIRA, 2008).

Coelho (2008) descreve que os direitos humanos são inerentes à própria natureza humana e por isso são invioláveis, intemporais e universais. Já os direitos fundamentais são os direitos ordenados e presentes numa ordem jurídica concreta.

Comparato (2010) relata a distinção entre direitos fundamentais e humanos na perspectiva da doutrina germânica:

É ai que se põe a distinção, elaborada pela doutrina jurídica germânica,
entre os direitos humanos e direitos fundamentais (Grundrechte). Estes
últimos são os direitos humanos reconhecidos como tais pelas autoridades
às quais se atribui o poder político de editar normas, tanto no interior dos
Estados quanto no plano internacional; são os direitos humanos positivados
nas Constituições, nas leis, nos tratados internacionais. Segundo outra
terminologia, fala-se de direitos fundamentais típicos e atípicos, sendo
esses os direitos humanos ainda não declarados em textos normativos
(2010. p. 70-71).

Ainda que exista uma discussão teórica sobre a distinção conceitual entre os direitos humanos e direitos fundamentais, é necessário ressaltar que, no Brasil, cabe ao Estado Democrático de Direito proteger tanto os direitos fundamentais, positivados no texto constitucional, quanto os direitos humanos positivados nos tratados internacionais e referenciados pelo Congresso. Logo, os dois conceitos são protegidos pelo ordenamento jurídico brasileiro (GOMES, 2008).

Os direitos fundamentais apresentam as seguintes características: a) historicidade, pois são direitos históricos que se desenvolvem de forma progressiva; b) inalienabilidade, visto que não são alienáveis; c) imprescritibilidade, porque não

direitos individuais e coletivos e o Capítulo II, direitos sociais. Já no artigo 17 inclui a expressão direitos fundamentais da pessoa humana e no artigo $6^{\circ} \S 4^{\circ}$, IV, direitos e garantias individuais. 
prescrevem por não serem exercidos; d) irrenunciabilidade, pois nenhum indivíduo pode renunciá-los; e) relatividade, visto que em um conflito de direitos fundamentais o que prevalece é o direito mais benéfico para o sujeito; f) universalidade, porque os direitos fundamentais são aplicados a todos os brasileiros e estrangeiros residentes no Brasil e; g) imediatos, pois devem ser aplicados e ser efetivos de modo imediato (PINHO, 2011, p. 97).

Nota-se que a evolução dos direitos fundamentais possui uma classificação progressiva, chamada de dimensão ou geração ${ }^{6}$, em que aos poucos foram reconhecidos constitucionalmente, sendo esses divididos em direitos fundamentais de primeira, segunda e terceira geração.

Os direitos fundamentais de primeira geração surgiram no Estado Liberal e correspondem aos direitos de liberdade, compreendendo os direitos individuais e políticos dentro do modelo clássico da Constituição. São impostos limites à atuação do Estado protegendo direitos considerados indispensáveis a cada pessoa humana. Exemplos de direitos individuais: liberdade de locomoção e inviolabilidade do domicílio (PINHO, 2011, p. 98).

$\mathrm{Na}$ implantação do Estado Social são reconhecidos os direitos de segunda geração, os quais têm por fundamento a preocupação com as necessidades mínimas do ser humano para uma vida digna. Significam uma prestação do Estado em favor dos menos favorecidos pela ordem social e econômica. Surgem os direitos sociais, que exigem a atuação ativa do Estado na redução dos problemas sociais, acentuando o princípio da igualdade. São exemplos de direitos sociais: salário mínimo, aposentadoria e férias remuneradas (NETTO, 2010; PINHO, 2011, p. 98).

Os direitos de terceira geração referem-se aos direitos de fraternidade e/ou solidariedade. São voltados para a coletividade em massa e surgiram em razão dos processos de industrialização e urbanização, em que os conflitos sociais não eram resolvidos satisfatoriamente dentro da antiga tutela jurídica que era voltada apenas para a defesa dos direitos individuais. São exemplos: direito ao meio ambiente

\footnotetext{
${ }^{6} \mathrm{O}$ autor dessa distinção em dimensões ou gerações de direitos foi Karel Vazak em 1979, mas foi Norberto Bobbio quem publicou essa distinção (A Era dos Direitos). No Brasil o principal autor que trata desse assunto é Paulo Bonavides. Quando se fala em geração dá a entender que uma substitui a outra, entretanto, elas coexistem, assim muitos dizem que são dimensões e não gerações.
} 
saudável, à paz, à saúde, à alimentação e à educação pública (COELHO, 2008; PINHO, 2011, p. 99).

Observa-se que, com a evolução dos direitos fundamentais, esses foram gradativamente ampliados e associados a valores de igualdade, fraternidade e cidadania, além da proteção dos direitos da coletividade. Os direitos fundamentais são de singular importância para o Estado de Direito e estrutural no ordenamento jurídico, informando e justificando o Estado Constitucional:

O Estado Constitucional, vertebrado pelos princípios da juridicidade, da democracia e da solidariedade, pode ser designado Estado de Direitos Fundamentais, considerando-se a centralidade assumida pelos direitos fundamentais como fim e medida de estruturação, organização e atuação do Estado e do seu relacionamento com a sociedade e com seus indivíduos (NETTO, 2010, p. 34).

\subsection{O ESTADO DEMOCRÁTICO DE DIREITO}

O Estado Democrático de Direito é um aperfeiçoamento do tradicional conceito de Estado de Direito. É regido por leis e gerido por representantes legitimamente eleitos pelo povo, além de reconhecer os direitos humanos (PINHO, 2011, p. 90).

\subsubsection{Evolução do Estado Democrático de Direito}

No século XVII, com a Revolução Inglesa, desponta o Constitucionalismo Ocidental, que é quando nasce a ideia de um governo respaldado em leis.

A Revolução Francesa, com ideologias liberais baseadas na liberdade, fraternidade e igualdade, tem na separação dos poderes e na justiça o seu ponto de partida e acrescenta a universalidade dos direitos fundamentais. Os indivíduos passam a ser sujeitos de direitos e garantias (AMARAL JUNIOR, 2010).

Já a Revolução Estaduniense manteve a legalidade e universalidade dos direitos, as garantias fundamentais e a separação dos poderes, mas rompeu com a Monarquia e criou a noção de República. Consolida-se o Constitucionalismo Moderno, que rompe com o Estado de Política e cria o Estado de Direito (LOPES, 2002, p. 322). 


\subsection{EVOLUÇÃO CONSTITUCIONAL BRASILEIRA E OS DIREITOS SOCIAIS FUNDAMENTAIS}

A Constituição de 1824 foi a mais duradoura da história brasileira e foi influenciada pela doutrina liberal, com os princípios de liberdade, igualdade e fraternidade, apesar da existência de relações sociais, políticas e econômicas marcadas pela desigualdade. O status de cidadão era concedido apenas aos homens ricos e livres e o imperador detinha todos os poderes (IURCONVITE, 2010).

Na Constituição de 1891 surge o modelo republicano, o presidencialismo, a forma federativa de Estado. Adotou-se a tripartição dos poderes, na concepção de Montesquieu, formada pelos poderes Executivo, Legislativo e Judiciário (VAINER, 2010).

Em 1930 chega ao fim a Primeira República e o Brasil começa a viver, por quatro anos, um período de ditadura (VAINER, 2010). Em 1934, uma nova Constituição trouxe inovações sociais e trabalhistas e estabeleceu o Estado Social no Brasil. O Estado passou a desempenhar condutas voltadas à proteção do cidadão, desempenhando um papel mais intervencionista na economia e susceptível às demandas sociais (IURCONVITE, 2010).

Em 1937 o país sofre um golpe de Estado e passa a ser governado por meio de decretos-leis, findando, de certa forma, a tripartição dos poderes e reduzindo os direitos e as garantias individuais (VAINER, 2010).

A Constituição de 1946, bastante avançada para a época, destaca-se como um avanço da democracia e das liberdades individuais do cidadão. A atenção aos direitos sociais ressurge e o rol de direitos e garantias individuais amplia-se (BASTOS, 2002, p. 200).

Após 20 anos, surge a Constituição de 1967, que tem sua atenção voltada à proteção da indústria e ao comércio em detrimento do homem. $E$, com isso, novamente os direitos individuais foram limitados (ARAUJO e SERRANO, 2008).

Por fim, a Constituição de 1988 rompe o período político anterior e busca diminuir as injustiças sociais que visa pelo modelo de produção capitalista, no qual o Estado desempenha o papel de agente normativo e regulador. O novo texto constitucional dá ênfase e garante os direitos sociais. Legitima-se, então, o Estado 
Democrático de Direito que tem como princípios a soberania, a cidadania, os valores sociais de trabalho e da livre iniciativa e o pluralismo político (VAINER, 2010).

Nota-se que a Constituição da República Federativa de 1988, Constituição Cidadã, é a que ampliou os direitos sociais e teve por objetivo fundamental a efetivação de tais direitos (IURCONVITE, 2010).

\subsection{OS DIREITOS SOCIAIS}

Os direitos sociais, direitos de toda a sociedade, visam a melhora das condições de vida e de trabalho e devem ser garantidos e protegidos pelo Estado. $O$ Estado é conhecido por ser um Estado Social de Direito e deve garantir a igualdade social a todos, inclusive aos hipossuficientes.

Para Moraes (2010):

Direitos sociais são direitos fundamentais do homem, caracterizando-se como verdadeiras liberdades positivas, de observância obrigatória em um Estado Social de Direito, tendo por finalidade a melhoria de condições de vida aos hipossuficientes, visando à concretização da igualdade social, e são consagrados como fundamentos do Estado Democrático, pelo art. 1ํㅡ, IV, da Constituição Federal (MORAES, 2010, p. 197).

Os direitos sociais estão apresentados no artigo $6^{\circ}$ da Constituição da República Federativa do Brasil, de 05 de outubro de 1988, e a garantia desses direitos está explicitada por todo o ordenamento jurídico. Assim, a proteção dos direitos sociais deve ser concretizada pelo Estado.

\subsubsection{Os Direitos Sociais na Constituição de 1988}

Os direitos sociais encontram-se em aspectos constitucionais e expressamente disciplinados no artigo 6º, caput, da Constituição Cidadã brasileira. 0 referido artigo em seu texto atual expõe que:

São direitos sociais a educação, a saúde, a alimentação, o trabalho, a moradia, o lazer, a segurança, a previdência social, a proteção à maternidade e à infância, a assistência aos desamparados, na forma desta Constituição. 


\subsection{O DIREITO À ALIMENTAÇÃO}

Dentro do contexto da internacionalização dos direitos humanos, uma das primeiras contribuições para o processo de entendimento do direito à alimentação iniciou-se a partir do discurso Four Freedoms ${ }^{7}$, declarado por Franklin Delano Roosevelt, presidente americano em 1941. No discurso, a "liberdade de não passar necessidade" (freedom from want) foi destacada como uma das quatro liberdades básicas (liberdade de expressão; liberdade de culto; liberdade de não sentir medo; e liberdade de não passar necessidade). Esse conceito está diretamente relacionado ao direito à alimentação, ou seja, de estar livre da fome (FERRAZ, 2013).

Em 1944, no discurso State of the Union, foi intensificado pelo presidente o conceito de liberdade de não passar necessidade, afirmando que os homens necessitados não seriam livres e que pessoas com fome e desempregadas constituíam matéria-prima para ditaduras:

We have come to a clear realization of the fact that true individual freedom cannot exist without economic security and independence.Necessitous men are not free men. People who are hungry and out of a job are the stuff of which dictatorships are made (ROOSEVELT, 1944).

Assim, a Carta das Nações Unidas de 1945 deu início ao movimento de internacionalização dos direitos humanos e, apesar de não consagrar expressamente o direito à alimentação, faz referências ao favorecimento pelas Nações Unidas de níveis mais alto de vida, trabalho efetivo e condições de progresso e desenvolvimento econômico e social (FERRAZ, 2013).

\subsubsection{O Direito à Alimentação no Contexto Internacional}

O direito fundamental à alimentação constitui um direito de segunda dimensão, denominado de direito social, e não deve ser entendido apenas como uma obrigação local ou regional. A responsabilidade pelo direito fundamental à

\footnotetext{
${ }^{7}$ In the future days, which we seek to make secure, we look forward to a world founded upon four essential human freedoms. The first is freedom of speech and expression - everywhere in the wold. The second is freedom of every person to worship God in his own way - everywhere in the world. The third is freedom from want - which, translated into world terms, means economic understandings which will secure to every nation a healthy peacetime life for its inhabitants - everywhere in the world. The fourth is freedom from fear - which, translated into world terms, means a world-wide reduction of armaments to such a point and in such a thorough fashion that no nation will be in a position to commit an act of physical aggression against any neighbor - anywhere in the world. That is no vision of a distant millennium. It is a definite basis for a kind for world attainable in our own time an generation. That kind of world is the very antithesisof the socalled new order of tyranny which the dictators seek to create with the crash of a bomb (ROOSEVELT, 1944).
} 
alimentação aparece em vários instrumentos internacionais ${ }^{8}$ de proteção dos direitos fundamentais, de âmbito global e regional (LAFER, 1988, p. 127).

Ele constitui um direito fundamental básico, firmado e legitimado em vários documentos internacionais, tais como declarações, pactos e convenções ao assumirem a premissa de que todos os direitos fundamentais são universais, indivisíveis, interdependentes e interrelacionados e cuja validade é perene.

A Declaração Universal dos Direitos Humanos validada pela AssembleiaGeral das Nações Unidas em 1948 apresenta uma referência do direito à alimentação, no artigo 25:

Toda pessoa tem direito a um padrão de vida capaz de assegurar a si e a sua família saúde e bem-estar, inclusive alimentação, vestuário, habitação, cuidados médicos e os serviços sociais indispensáveis, e direito à segurança em caso desemprego, doença, invalidez, viuvez, velhice ou em outros casos de perda de outros meios de subsistência fora de seu controle (ONU, 1948, n.p).

A Declaração Universal de Direitos Humanos é compreendida como interpretação autorizada da expressão "direitos humanos e liberdades fundamentais" incluída na Carta das Nações Unidas, tendo em si força jurídica, embora seja apenas uma recomendação das Nações Unidas, aceita sob a forma de resolução de sua Assembleia-Geral (CARVALHO, 2012).

8 Destacam-se alguns instrumentos internacionais (declarações, pactos e convenções) de incontestável importância, a saber: além da Declaração Universal dos Direitos Humanos (1948) e do Pacto Internacional dos Direitos Econômicos, Sociais e Culturais (1966), tem-se a Declaração das Nações Unidas dos Direitos dos Portadores de Deficiência (1975), que proclamou o tema da alimentação como direito. Nas previsões da Convenção sobre a Eliminação de Todas as Formas de Discriminação contra as Mulheres (1979), na Declaração sobre o Direito ao Desenvolvimento (1986) que assegurou o direito à alimentação. A Declaração dos Direitos da Criança (1959) e a Convenção das Nações Unidas sobre os Direitos da Criança (1989) reconheceram o direito de toda a criança ter um padrão de vida adequado ao seu desenvolvimento físico, mental, espiritual, moral e social. A Convenção no 169 da Organização Internacional do Trabalho (1989) concernente aos povos e às tribos indígenas em países, também proclama o direito à alimentação. Outras reuniões, documentos e cúpulas internacionais também trataram do tema: Conferência Mundial sobre Alimentação (1974), Declaração de Princípios e Programas de Ação da Conferência Mundial sobre Reforma Agrária e Desenvolvimento Rural (1979), Conferência Internacional sobre Nutrição (1992), Declaração e Programa de Ação de Viena da Conferência Mundial sobre Direitos Humanos (1993), Declaração e Programa de Ação da Cúpula Mundial para o Desenvolvimento Social-Copenhague (1995), Conferência de Pequim sobre a Mulher (1995), Declaração de Roma sobre Segurança Alimentar e o Plano de Ação da Cúpula Mundial de Alimentação (1996) e a Declaração do Milênio das Nações Unidas (2000). No plano regional tem-se o Protocolo de San Salvador, protocolo adicional à Convenção Americana sobre Direitos Humanos (1969), que no art. 12 estabelece que "todos têm direito à adequada nutrição que garanta possibilidade de gozar do maior nível de desenvolvimento físico, emocional e intelectual". Por sua vez, no espaço eurocomunitário tem-se a Carta Social Europeia que foi revista em 1996. 
O direito à alimentação tem duas linhas no direito internacional: o direito a uma alimentação adequada e o direito fundamental de estar livre da fome. Essas duas vertentes foram consideradas no Pacto Internacional sobre os Direitos Econômicos, Sociais e Culturais (PIDESC) em 1966, no artigo 11:

\begin{abstract}
Os Estados-Parte do presente Pacto reconhecem o direito de toda pessoa a um nível de vida adequado para si próprio e sua família, inclusive à alimentação, vestimenta e moradia adequadas, assim como a sua melhoria contínua de sua condição de vida. Os Estados- Parte tomarão medidas apropriadas para assegurar a consecução desse direito, reconhecendo, nesse sentido, a importância essencial da cooperação internacional fundada no livre consentimento.

Os Estados-Parte do presente pacto, reconhecendo o direito fundamental de toda pessoa de estar protegida contra a fome, adotarão, individualmente e mediante cooperação internacional, as medidas, inclusive programas concretos, que se façam necessárias para:

a. Melhorar os métodos de produção, conservação e distribuição de gêneros alimentícios pela plena utilização dos conhecimentos técnicos e científicos, pela difusão de princípios de educação nutricional e pelo aperfeiçoamento e pela reforma dos regimes agrários, de maneira que se assegurem a exploração e a utilização mais eficazes dos recursos naturais;

b. Assegurar uma repartição equitativa dos recursos alimentícios mundiais em relação às necessidades, levando-se em conta os problemas tanto dos países importadores quanto os exportadores dos gêneros alimentícios (BRASIL, 1992, p. 8715).
\end{abstract}

O Brasil foi um dos Estados-Parte do PIDESC, aderindo ao pacto em 24 de janeiro de 1992 que foi incluído à legislação nacional pelo Decreto n 591, de 06 de julho de 1992.

O Comitê de Direitos Econômicos, Sociais e Culturais (CDESC) ${ }^{9}$ das Nações Unidas, responsável por monitorar e gerar efeito ao PIDESC, em seu Comentário Geral de ํㅜ 12, de 12 de maio de 1999 (em sua vigésima sessão), abordou sobre o direito a uma alimentação adequada em seu documento, propiciando as bases conceituais e constituindo os meios para a sua realização e utilização. O Comitê estabeleceu que "o direito humano à alimentação adequada é de importância crucial para a fruição de todos os direitos" (CARVALHO, 2012).

Em 1996, na Cúpula Mundial sobre Alimentação presidida pela Organização das Nações Unidas para Agricultura e Alimentação (Food and Agriculture Organization of the United Nations - FAO), foi discutida a fome no mundo e, num ato

\footnotetext{
${ }^{9}$ O Comitê de Direitos Econômicos, Sociais e Culturais (CDESC) é o órgão que supervisiona o cumprimento do Pacto Internacional de Direitos Econômicos, Sociais e Culturais (PIDESC) por meio da elaboração de relatórios ou pareceres com conclusões e recomendações para os Estados. Não está previsto no Pacto, senão que foi criado pela Resolução 1985/17, de 28 de Maio de 1985, do Conselho Econômico e Social (ECOSOC) das Nações Unidas para o desempenho das funções apresentadas na parte IV do Pacto (artigos 16 a 25).
} 
protocolar, todos os 185 países presentes e a Comunidade Europeia comprometeram-se a erradicar a fome de todos os países, estabelecendo a Declaração de Roma sobre Segurança Alimentar e reafirmando o direito à alimentação adequada e o direito básico de todos estarem livres da fome (MANIGLIA, 2009, p.125).

Cinco anos depois ${ }^{10}$, em 2002, em Roma, ocorreu a Cúpula Mundial de Alimentação, ocasião em que os Chefes de Estado e Governo convidaram o Conselho da FAO a estabelecer um grupo de trabalho para elaborar, com a participação das partes interessadas, um conjunto de diretrizes voluntárias para apoiar os Estados Membros na realização do direito à alimentação adequada. Assim, a FAO adotou a resolução denominada "Diretrizes Voluntárias em Apoio à Realização Progressiva dos Direitos à Alimentação Adequada no Contexto da Segurança Alimentar e Nutricional"11, aprovada em novembro de 2004 pelos 151 países que compõem a FAO. Tais diretrizes enfatizam as obrigações do governo, fundamentando-se nas constituições nacionais e na legislação internacional dos direitos humanos que preveem o direito de estar livre da fome e o acesso sustentável à alimentação adequada (FERRAZ, 2013).

Para Ferraz (2013), o Direito Humano à Alimentação Adequada passa a ser tratado de acordo com suas diversas dimensões e considera a interdependência com outros direitos humanos. Por exemplo: o DHAA de um bebê menor de seis meses passa pelo direito da mãe de praticar aleitamento materno e o DHAA da população urbana depende da acessibilidade física e econômica (preços justos) e da informação sobre os alimentos.

\footnotetext{
${ }^{10}$ FAO. Declaração Aprovada na Cúpula Mundial de Alimentação: cinco anos depois. World Food Summit: five years later. FAO Heardquarters, Rome, Italy, 10-13 June 2002. Paragrafo 10. Disponível em: http://www.fao.org/worldfoodsummit/english/infocirc-e.pdf. Acesso em: 28 de março de 2016.

${ }^{11}$ COMITE DE SEGURANÇA ALIMENTAR MUNDIAL. Sessão (30: 2004; Roma Itália). Diretrizes Voluntárias em Apoio à realização progressiva do direito humano à alimentação adequada no Contexto da segurança alimentar e nutricional, Roma, 20-23 de setembro de 2004. Brasilia: Ação Brasileira pela Nutrição e direitos Humanos (ABRANDH), 2005.
} 
A Cúpula Mundial da Alimentação ${ }^{12}$ sobre Segurança Alimentar, realizada em 2009, renovou, por meio da Declaração da Cúpula Mundial sobre Segurança Alimentar, o compromisso feito em 1996 de erradicar a fome de forma sustentável. A Declaração também menciona a necessidade de um aumento no fundo para agricultura nacional e internacional, novos investimentos no setor rural e melhoria da administração das questões globais (CARVALHO, 2012).

\subsubsection{O Direito à Alimentação no Contexto Nacional}

A Constituição do Brasil de 1988 abrangeu vários direitos consagrados na Declaração Universal dos Direitos Humanos em suas disposições e estabeleceu mecanismos processuais que buscam dar poder a esses direitos. O princípio da Constituição identifica em seu Preâmbulo o Brasil como um Estado Democrático de Direito, "destinado a assegurar o exercício dos direitos sociais e individuais, a liberdade, a segurança, o bem-estar, o desenvolvimento, a igualdade e a justiça (...)" (BRASIL, 1988). Segundo o artigo 6o da Constituição Federal:

São direitos sociais a educação, a saúde, a alimentação, o trabalho, a moradia, o lazer, a segurança, a previdência social, a proteção à maternidade e à infância, a assistência aos desamparados, na forma desta Constituição.

O direito à alimentação, desde a promulgação da Constituição Federal de 1988, é previsto no artigo 227: "é dever da família, da sociedade e do Estado assegurar à criança e ao adolescente, com absoluta prioridade, o direito à vida, à saúde, à alimentação" (BRASIL, 1988). Além disso, algumas normas constitucionais, já reconheciam a alimentação como um direito constitucional, como as normas que determinam a função social da propriedade (artigo $5^{\circ}$, inciso XXIII), as que dispõem sobre a demarcação de terras indígenas (artigo 231) e dos territórios quilombolas (artigo 63 do Ato das Disposições Constitucionais Transitórias - ADCT), as normas que dispõem sobre o meio ambiente (artigo 225), a dignidade da pessoa humana (artigo 1ํ, inciso III) (BRASIL, 1988), estão relacionadas às questões do direito à alimentação.

\footnotetext{
${ }^{12}$ FAO. Declaração de Roma sobre Segurança Alimentar Mundial e Plano de Ação da Cúpula Mundial da Alimentação. Roma, 1996. Disponível em: <http://www.fao.org/DOCREP/003/W3613P/W3613P00.HTM\#Note1>.
} 
A partir da $1^{\text {a }}$ Conferência Nacional de Alimentação e Nutrição em 1986 no Brasil e das Conferências Nacionais de Segurança Alimentar e Nutricional (II CNSAN - 2004 e III CNSAN - 2007), consolidou-se a alimentação como um direito de cidadania, com vista de encaminhamentos na Constituição Federal.

Um marco foi a aprovação da Lei Orgânica de Segurança Alimentar e Nutricional (LOSAN), Lei no 11.346, de 15 de setembro de 2006, que incorporou os princípios dos instrumentos internacionais sobre o direito fundamental à alimentação (universalidade, indivisibilidade, inalienabilidade, interdependência e interrelacionariedade), e criou o Sistema Nacional de Segurança Alimentar e Nutricional (SISAN) ao visar assegurar o direito fundamental à alimentação e estabelecer um conjunto de definições com diretrizes, princípios, objetivos e a própria composição do SISAN (LEÃO, 2013). A LOSAN dispõe no seu artigo 2º:

A alimentação adequada é um direito fundamental do ser humano, inerente à dignidade da pessoa humana e indispensável à realização dos direitos consagrados na Constituição Federal, devendo o poder público adotar as políticas e ações que se façam necessárias para promover e garantir a segurança alimentar e nutricional da população (BRASIL, 2006, p. 1).

Ressalta-se que direito fundamental à alimentação era apenas mencionado e contido explicitamente em legislação infraconstitucional, e não era reconhecido no rol de direitos fundamentais na Constituição Federal de 1988. Desse modo, foi criada uma frente parlamentar para que pudesse ser incluído o direito à alimentação como direito fundamental social no rol dos direitos e garantias fundamentais na atual Constituição brasileira. Assim, em 4 de fevereiro de 2010, por meio da publicação da EC n 64/2010, ao alterar o artigo 6º da Constituição estabeleceu o direito à alimentação como direito fundamental social. (ESTORNINHO, 2013. p. 69). A Emenda $n^{\circ} 64$ apresentou a seguinte redação para o artigo 6ำ da Constituição Federal:

São direitos sociais a educação, a saúde, a alimentação, o trabalho, a moradia, o lazer, a segurança, a previdência social, a proteção à maternidade e à infância, a assistência aos desamparados, na forma desta Constituição (BRASIL, 2010, p.1).

Essa inclusão no texto constitucional brasileiro constituiu um marco para o reconhecimento do direito à alimentação no catálogo de direitos fundamentais ao reafirmar sua natureza de direito fundamental. É imprescindível que os direitos 
fundamentais sejam reconhecidos e minimamente assegurados, caso contrário não haverá espaço para a dignidade da pessoa humana.

A inclusão de direitos sociais no texto constitucional, em particular o direito à alimentação, permite melhores condições de vida aos mais fracos. Pois a concretização dos direitos sociais contribui para a realização da igualdade de situações sociais desiguais (SILVA, 2004).

O direito à alimentação deve ser compreendido na igualdade. Para Dalmo Dallari (1991), não deve ser admitida a desigualdade social que assegura tudo a alguns, desde a melhor condição econômica e preparo intelectual, negando tudo a outros.

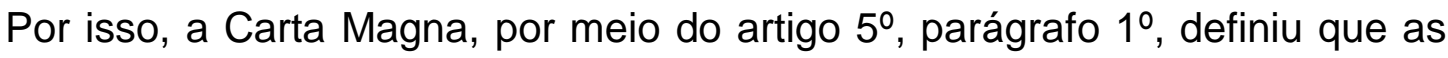
normas definidoras dos direitos e garantias fundamentais possuem aplicabilidade imediata. Assim, essas normas deixam de ser meros programas e tornam-se políticas públicas. Além disso, esses direitos foram incluídos no rol das cláusulas pétreas, não podem ser suprimidos, são intocáveis, conforme dispõe o artigo $6^{\circ}$, parágrafo $4^{0}$ da Constituição, que também possibilita a todos provocar o Poder Judiciário na falta de cumprimento pelo Estado na garantia desses direitos (SILVA, 1999).

No tocante ao direito à alimentação, sabe-se que sua garantia depende de políticas em diferentes setores relacionados à Segurança Alimentar e Nutricional (SAN) e demandam uma abordagem intersetorial. Atualmente, o Brasil adota o seguinte conceito de SAN:

A Segurança Alimentar e Nutricional consiste na realização do direito de
todos ao acesso regular e permanente a alimentos de qualidade, em
quantidade suficiente, sem comprometer o acesso a outras necessidades
essenciais, tendo como base práticas alimentares promotoras de saúde que
respeitem a diversidade cultural e que sejam ambiental, cultural, econômica
e socialmente sustentáveis (BRASIL, 2006, p. 1).

Para Leão (2013), são necessárias políticas que incidam sobre toda a cadeia produtiva de alimentos (produção, transformação, distribuição, abastecimento e consumo) e devem estar articuladas e complementadas com: 
outros meios de acesso à água, oferta de equipamentos públicos como cozinhas comunitárias, restaurantes populares, entre outros;

Políticas de saúde que incidam sobre os determinantes sociais da saúde e de doenças, que garantam o acesso a serviços e atenção à saúde nos diferentes níveis, além de programas de suplementação nutricional, promoção de hábitos saudáveis e saneamento;

Políticas de educação que têm papel relevante na promoção do Direito Humano à Alimentação Adequada (DHAA). Maiores níveis de escolaridade estão relacionados a melhores índices de saúde. Desta forma, políticas de combate ao analfabetismo e educação básica contribuem para a garantia do Direito Humano à Alimentação Adequada (DHAA);

Políticas específicas para povos e comunidades tradicionais, que são de fundamental importância para a garantia do DHAA destas populações, geralmente mais ameaçadas, tanto devido às suas características particulares e quanto às iniquidades sofridas historicamente (LEÃO, 2013, p. 37).

No contexto da saúde pública, merece destaque a Política Nacional de Alimentação e Nutrição (PNAN), que tem como pressupostos o direito à saúde e à alimentação. A PNAN tem como objetivo:

A melhoria das condições de alimentação, nutrição e saúde da população brasileira, mediante a promoção de práticas alimentares adequadas e saudáveis, a vigilância alimentar e nutricional, a prevenção e o cuidado integral dos agravos relacionados à alimentação e nutrição (BRASIL, 2012b, p. 21).

\subsection{O DIREITO À SAÚDE}

O conceito de saúde é compreendido a partir de um elenco de saberes, que não se limitam ao campo da medicina, que vão além do conjunto das ciências médicas e que alcançam a sociologia, a antropologia, a filosofia e o direito. Mesmo que frequentemente seja abordada por oposição à noção de doença, saúde significa muito mais do que a ausência de enfermidade ou de acesso a medicamentos/ insumos ou procedimentos terapêuticos.

Assim, saúde é um campo de interesse tanto às ciências da saúde quanto às ciências sociais. A epidemiologia contemporânea, por exemplo, não se limita ao estudo de fatores biológicos e microbiológicos das doenças, investigando também os fatores sociais da saúde das populações (BARATA, 2005, p. 7-17). A percepção social do que é saúde tem tamanha abrangência que opta, ao invés de definir um conceito de saúde, em analisar "as possíveis representações no ambiente social" (AITH, 2007, p. 44). Nesse sentido, saúde pode assumir uma significação positiva, como a ideia de bons hábitos de vida, de equilíbrio, de higiene, de consciência ecológica, de práticas de exercícios físicos, de alimentação saudável, etc. 
Mesmo com os avanços nos debates sobre o conceito de saúde, ainda persiste uma concepção individual da saúde, conforme a definição adotada pela Organização Mundial de Saúde (OMS), em que saúde é um estado de completo bem-estar físico, mental e social e não consiste apenas na ausência de doença ou de enfermidade (OMS, 1946).

Foucault analisa o surgimento da medicina social, de forma a compreender a saúde pública como uma arena de embate social e tensão entre liberdade e igualdade. De fato, o Estado assumiu a tarefa de promover a saúde pública, mas esse processo histórico não foi pautado pelo ideal de um direito humano e sim a ideia de exercer um poder sobre a sociedade. E nesse sentido a medicina se construiu como uma estratégia bio-política, pois foi a partir do controle do corpo que se desenhou o controle da sociedade (FOUCAULT, 1979, p. 80-84).

E somente depois que o Estado já exercia o poder por meio da saúde pública que ocorreu o reconhecimento de um direito à saúde. E, como direito, a saúde é um espaço de tensão entre liberdade e igualdade. Um exemplo foi o enfrentamento das epidemias, ora como a lepra, que excluía o doente do convívio social, ora no modelo da peste, que o internava em reclusão e a liberdade individual era limitada pelo interesse público mediado pelo poder estatal (FOUCAULT, 1979, p. 88-89).

Para Dallari (2006, p. 252), a moderna concepção de saúde pública remonta ao surgimento do Estado Moderno. Com o modelo do Welfare State, no século XX, firmou-se a saúde como responsabilidade estatal e atuação do Estado para defender a saúde pública, tornando-a política de Estado.

\subsubsection{Histórico do Direito à Saúde no Brasil}

Constituída como um direito fundamental, a saúde tem implicações diretas no bem-estar dos indivíduos, na integridade da sociedade e na produtividade da economia. Por esse motivo, encontra-se agregada ao rol dos direitos humanos. Mas o amplo acesso à saúde só foi reconhecido constitucionalmente, como direito fundamental, quando da promulgação da Constituição da República Federativa do Brasil de 1988, cujo processo constituinte, num espaço democrático, teve também alicerce em ideias de congressistas progressistas, amparados por intelectuais da Reforma Sanitária (BRASIL, 2007, p. 12). 
O período colonial foi marcado por uma catástrofe demográfica da população indígena, decorrente da escravização e matanças, que disseminou doenças "importadas" da Europa. Mas como os índios e os negros eram pertencentes aos últimos escalões da sociedade, as suas condições de saúde eram deploráveis. Não menos heterogêneas eram as condições de saúde da população branca, o que variava conforme as classes sociais (BERTOLLI FILHO, 2001).

Sabe-se que não havia um sistema de proteção sanitária para a população, além disso, a medicina realizada na época pautava-se numa combinação indiscriminada de conhecimentos de povo diferentes.

Em 1922, com a Proclamação da Independência, houve mudanças no cenário médico brasileiro. Dentre as principais podemos destacar a regulamentação do exercício da medicina e o acesso a alguns medicamentos e tratamentos, além da criação de escolas de medicina. Em 1850, criou-se a Junta Central de Higiene Pública. Porém, a "população não associava competência terapêutica com diplomas e as autoridades faziam vistas grossas à multiplicidade de anúncios que ofereciam, para os mais diversos agravos, remédios que prometiam cura" (FREYRE, 1977, p.44-45).

Inúmeras foram as regulamentações sanitárias no período compreendido entre a Proclamação da República em 1824 até a Promulgação da Constituição Cidadã, como foi denominada na Carta Magna de 1988.

A Constituição de 1934 incluiu o direito à saúde no texto constitucional pela primeira vez, mas somente como uma competência concorrente entre a União e os Estados, não o garantindo explicitamente a todos os indivíduos. Já a Constituição de 1937 determinou à União estabelecer normas de defesa e proteção da saúde, sobretudo, das crianças (BERTOLLI FILHO, 2001, p. 34).

A Constituição de 1946 manteve a competência legislativa da União quanto às normas de proteção da saúde, assim como a Carta Constitucional de 1967. No entanto, a EC de 1969 estabeleceu aos municípios um percentual de aplicação nos programas de saúde, dos fundos financeiros repassados pela União.

Ressalta-se que o tema saúde já constava nos textos constitucionais brasileiros anteriores a 1988, embora com sentido organizativo e administrativo: 
É espantoso como um bem extraordinariamente relevante à vida humana só na Constituição de 1988 tenha sido elevado à condição de direito fundamental do homem. E há de informar-se pelo princípio de que o direito à vida de todos os seres humanos significa também que, nos casos de doença, cada um tem o direito ao tratamento condigno de acordo com 0 estado atual da Ciência Médica, independente da sua situação econômica, sob pena de não ter mais valor sua consignação em normas constitucionais. O tema não era de todo estranho ao nosso direito constitucional anterior, que dava competência à União para legislar sobre defesa e proteção da saúde; mas isso tinha sentido de organização administrativa de combate às endemias e epidemias. Agora é diferente, trata-se de direito do homem (SILVA, 2010, p.188).

Assim, a Constituição de 1988 agregou no seu texto a saúde como direito fundamental, conferindo-lhe uma proteção jurídica especial e assegurando-a como direito de todos e dever do Estado e que deve ser garantida por meio de políticas públicas, cabendo aos Poderes Executivo e Legislativo, mediante a elaboração de leis, a definição de prioridades e a escolha dos meios para sua realização (DELDUQUE e OLIVEIRA, 2006, p. 9).

\subsubsection{Carta Magna de 1988: Garantia da Saúde como Direito Fundamental}

Os textos constitucionais anteriores à Constituição Federal de 1988 apenas determinavam aos entes federados a competência para legislar sobre saúde, sendo o direito à saúde reconhecido apenas para os trabalhadores com vínculo formal de trabalho. Restava aos excluídos dessa classe a assistência caridosa prestada pelas entidades filantrópicas (MÂNICA, 2010, p.102).

A saúde era apenas um benefício da Previdência Social e, nessa perspectiva, as políticas públicas de promoção à saúde foram negligenciadas durante décadas. Esse cenário foi modificado pelo movimento da Reforma Sanitária entre o final dos anos 70 e início dos anos 80, em que setores da sociedade, técnicos, intelectuais, acadêmicos, partidos políticos e diversos movimentos sociais mobilizaram-se (BRASIL, 2007b, p.7):

Com a redemocratização, intensificou-se o debate nacional sobre a universalização dos serviços públicos de saúde. O momento culminante do "movimento sanitarista" foi a Assembleia Constituinte, em que se deu a criação do Sistema Único de Saúde. A Constituição Federal estabelece, no art. 196, que a saúde é "direito de todos e dever do Estado", além de instituir o "acesso universal e igualitário às ações e serviço para sua promoção, proteção e recuperação". A partir da Constituição Federal de 1988, a prestação de serviços públicos de saúde não mais estaria restrita aos trabalhadores inseridos no mercado formal. Todos os brasileiros, independentemente de vínculo empregatício, passaram a ser titulares do direito à saúde (BRASIL, 2007b, p. 7). 
A Constituição Federal de 1988 assume a saúde como um direito social no art. 6ํㅡ, estabelecendo nos artigos 196 a 201 uma estrutura política complexa e abrangente para o sistema de saúde brasileiro, compreendendo a União, Estados, Distrito Federal e os Municípios na elaboração e execução das políticas públicas de saúde. O art. 196 estabelece que a saúde é "um direito de todos e dever do Estado, garantido mediante políticas sociais e econômicas que visem à redução do risco de doença e outros agravos e ao acesso universal e igualitário às ações para sua promoção, proteção e recuperação" (BRASIL, 1988). Assim:

Promover a saúde significa intervir socialmente na garantia nos direitos e nas estruturas econômicas que perpetuam as desigualdades na distribuição de bens e serviços. As políticas de saúde vêm no sentido de implementar estratégias governamentais que visam corrigir os desequilíbrios sociais e proporcionar a redução das desigualdades sociais (PESSINI e BARCHIFONTAINE, 2002, p. 93).

A constitucionalização dos direitos fundamentais no Brasil representa a prerrogativa dos cidadãos de reivindicarem sua proteção ao Poder Judiciário, para concretização do princípio democrático (MORAES, 2006; PIOVESAN, 2004). Por si só, tal prerrogativa não foi suficiente para garantia do acesso à saúde.

No que tange ao direito à saúde pode-se dizer que o desenvolvimento teórico acompanhou - a partir de 1988, com atraso, portanto - caminho percorrido pela afirmação da teoria dos direitos fundamentais. $O$ entendimento positivista-legalista, segundo o qual o direito é a regra posta pelo legislador, cedeu espaço para uma teoria jurídica em que as novas funções estatais constitucionalmente previstas passaram a ser reconhecidas como verdadeiras normas jurídicas aptas a provocar efeitos concretos (MÂNICA, 2010, p.103).

Era preciso reconhecer que a saúde não devia apenas figurar como direito no papel, mas, acima de toda norma, ela devia ser efetivamente garantida. Para Dallari:

Fica evidente a dificuldade que existe para a garantia do direito quando se considera a amplitude da significação do termo saúde e a complexidade do direito à saúde que depende daquele frágil equilíbrio entre a liberdade e a igualdade, permeando pela necessidade de reconhecimento do direito do Estado ao desenvolvimento. Encontrar o meio de garantir efetivamente 0 direito à saúde é a tarefa que se impõe de modo ineludível aos atuais constituintes brasileiros. Não basta apenas declarar que todos têm direito à saúde; é indispensável que a Constituição organize os Poderes do Estado e a vida social de forma a assegurar a cada pessoa o seu direito. É função de todo profissional ligado à área da saúde contribuir para o debate sobre as formas possíveis de organização social e estatal que possibilitem a garantia do direito à saúde. [...] A nova Constituição do Brasil tratará certamente da saúde, reconhecendo-a como um dos direitos fundamentais dos brasileiros. É indispensável, porém, que ela preveja mecanismos para que nenhum dos direitos firmados seja negado na prática constitucional (DALLARI,1988, p. 60 e 62). 
Para efetivação do direito à saúde, a Constituição previu a implantação de um sistema público de saúde, de acesso universal e igualitário, regulamentado por legislação infraconstitucional. Assim, foi implantado o Sistema Único de Saúde (SUS), por meio do qual o Estado garante a efetividade do direito à saúde.

\subsection{A JUDICIALIZAÇÃO DAS POLITICAS PÚBLICAS}

Desde a publicação da Constituição Federal de 1988, particularmente no âmbito da jurisdição constitucional, tem sido comum a busca da sociedade pela efetivação dos direitos sociais. Assim, com a positivação dos direitos sociais nas normas jurídicas do Estado, esses direitos são introduzidos no sistema jurídico.

Ao mesmo tempo em que se ampliaram os direitos sociais, por meio de lutas e conquistas, passou-se a exigir do Estado políticas para garantia desses direitos, seja por meio do Poder Legislativo ou do Poder Executivo. A sociedade busca a efetivação dos direitos sociais e, diante de um Poder Executivo limitado pelos acordos macroeconômicos e políticos, demanda no Poder Judiciário, reconhecendoo efetivamente como uma das instituições do poder estatal e com a possibilidade de efetivação destes direitos.

Os direitos sociais representam uma nova concepção de direitos dentro do sistema jurídico, que extrapola a dimensão individual. São direitos que dizem respeito a uma coletividade e que necessitam de políticas públicas para sua efetivação.

A proteção dos direitos sociais pelo sistema jurídico precisa ser informada de elementos políticos. E, para que o sistema jurídico seja capaz de demandar os elementos políticos que envolvem os direitos sociais é preciso que estes elementos sejam expressos por forma jurídica e reconhecida pelo direito. Percebe-se que o sistema jurídico é fundamentado na teoria pura do direito, com base no purismo metodológico e, desta forma, encontra dificuldades para adotar a concepção de políticas públicas em suas operações internas (MARQUES, 2008).

As políticas públicas são redigidas de diversos modos, sem um padrão jurídico claro e definido. Para Bucci (2002, p. 262) "o modelo das políticas públicas, concebido como forma de implementação do Estado de Bem-Estar, pairou acima ou ao lado das estruturas jurídicas tradicionais, não sido integrado ao ordenamento 
jurídico". O que causa dificuldades para um sistema "puro" informado apenas pelo próprio direito.

Faria (2002, p. 94) relata que os direitos sociais vêm complexificando a aplicação da lei. Verifica-se que o Judiciário "força" a proteção dos direitos sociais aos mesmos moldes dos direitos individuais, tratando igualmente direitos que, por essência, demandam tratamentos diferentes e dependem de estímulos políticos diferentes. E assim, verifica-se que as decisões judiciais não são capazes de resolver os problemas jurídicos que perpassam em torno da efetivação e garantia dos direitos sociais.

O termo judicialização da política tem servido para indicar "os efeitos da expansão do Poder Judiciário no processo decisório das democracias contemporâneas" (MACIEL e KOERNER, 2002, p. 114).

\subsubsection{A Judicialização do Direito à Alimentação}

O direito à alimentação está inserido nos extensos limites abrangentes da assistência social e ainda não adquiriu título específico, diferentemente dos direitos à saúde, educação e cultura.

Observa-se que os processos que solicitam alimentos ao Estado são mais uma modalidade de processo constitucional judicial, pois, sob o prisma da atuação do Poder Judiciário, este caracteriza um conjunto de atos mediante os quais o órgão jurisdicional atua conforme a vontade das normas constitucionais (DIMOULIS e LUNARDI, 2011, p. 9).

Nota-se que, ao determinar que o Estado forneça alimentos aos indivíduos (equivalente a determinar alimentação como direito social), o magistrado está expressando uma vontade constitucional, ou seja, demonstrando a atividade jurisdicional constitucional.

A partir da perspectiva da jurisdição constitucional ${ }^{13}$, é possível prever que muitos instrumentos processuais estão à disposição dos indivíduos que solicitam

\footnotetext{
${ }^{13}$ Em sentido estrito, jurisdição constitucional consiste na entrega aos órgãos do Poder Judiciário, da missão de solucionar os conflitos entre as normas jurídicas ordinárias (e complementares) e a Constituição. E, mais amplamente (sentido próprio), é a entrega ao Poder Judiciário da missão de solucionar conflitos constitucionais (SILVA, [s. d]).
} 
algum tipo de alimento ao Estado. A existência desse fundamento constitucional suscita a ideia de processo constitucional, que incorpora a ação civil pública, a ação popular e o mandado de segurança como possibilidades de controle judicial das políticas relacionadas ao direito à alimentação.

Para Lira (2013, p. 115) as ações ordinárias de conhecimento, além das ações cautelares e das tutelas de emergência, são instrumentos que possuem capacidade jurídica para os indivíduos que solicitam alimentos ao Estado junto aos Tribunais, além de chamar a atenção para o uso desses alimentos por indivíduos com algum agravo de saúde. O manejo dessas ações judiciais é a principal forma de judicializar e fiscalizar o cumprimento do direito à alimentação.

Ademais, nota-se que as ações coletivas são instrumentos de realização dos direitos fundamentais e o modo eficaz de garanti-los e, de fato, essas ações mostram-se como efetivos mecanismos de controle dos atos públicos (ARENHART, 2009).

O Estado, na figura da União, Estados, Distrito Federal e Municípios, possui a responsabilidade constitucional de garantir os direitos sociais. É de competência comum dos entes federados o cuidado com a assistência pública (a qual inclui a alimentação), a organização de políticas de abastecimento alimentar e o enfrentamento das causas da pobreza e dos fatores de marginalização. Tais responsabilidades devem ser solidárias (BURITY et al, 2010, p. 181).

No Brasil, verifica-se que as políticas públicas de alimentação são, na sua maioria, coordenadas e executadas pelo Poder Executivo Federal e pouco se noticia sobre iniciativas estaduais ou municipais, principalmente quando se olha para fora das grandes capitais. Assim, ainda há muito o que descentralizar para concretizar a vontade constitucional, pois todos os entes federados são competentes e responsáveis pelo direito à alimentação (LIRA, 2013, p. 118).

A legitimidade ativa pode ser conferida ao Ministério Público, quando, por exemplo, constatar-se que a violação ao direito à alimentação tenha ocorrido de forma difusa, coletiva ou individualmente, em decorrência do microssistema do processo coletivo (BURITY et al, 2010; LIRA, 2013, p. 118). 
Além disso, a assistência da Defensoria Pública tem particular importância no tema. É de extrema relevância ter instrumentos processuais preparados para atender àquele que busca o direito à alimentação contra os entes federados.

A judicialização do direito à alimentação é a tendência que se torna realidade. Apesar de estar sendo apresentada por meio de discussões pautadas nas leis infraconstitucionais, trata-se apenas de esperar o tempo de amadurecimento necessário para que seja possível conceber que, na realidade, requisitos burocráticos não foram impostos pela Constituição do Brasil para que o cidadão tenha direito à alimentação (LIRA, 2013, p. 132).

Ao exemplo da pacificação dos entendimentos acerca do direito constitucional à saúde, nas chamadas ações de medicamentos e procedimentos, há uma forte predisposição a que seja amplamente divulgado, reconhecido e judicializado o direito constitucional à alimentação.

\subsubsection{A Judicialização da Saúde}

O fenômeno da judicialização da saúde no Brasil é um dos temas vigentes nos debates envolvendo as instituições de ensino superior, operadores do direito, 0 governo e a própria sociedade civil organizada.

No Brasil, a Constituição Federal de 1988, ao classificar a saúde como um direito social e garantir a integralidade do acesso para todos os cidadãos, não projetou colocar em confronto os poderes republicanos, independentes e autônomos entre si, nem instigar o Poder Judiciário e determinar ao Executivo como deve gastar os recursos em saúde.

A Constituição pretendeu corrigir uma grave distorção que o país apresentava até o momento, que era de não permitir a todos os brasileiros acesso aos serviços de saúde, erro reparado com o disposto no artigo $6^{\circ}$ aliado ao artigo 196, que garantiu o acesso universal e igualitário.

O artigo 196 estabelece que a saúde é "direito de todos e dever do Estado". Institui também o "acesso universal e igualitário às ações e serviços para sua promoção, proteção e recuperação". O artigo 198 complementa que a atenção à saúde deve ser integral sem prejuízo das ações preventivas (BRASIL, 1988). Logo, 
a prestação do serviço público de saúde não mais estaria restrita aos trabalhadores inseridos no mercado formal, mas, sim, a todos os brasileiros, independentemente de vínculo empregatício.

Assim, as políticas públicas de saúde passaram a ser orientadas pelos princípios da universalidade, equidade do acesso às ações e serviços e pelas normas de descentralização da gestão, da integralidade da atenção e da participação da comunidade.

Para Silva (2006):

A saúde é concebida como direito de todos e dever do Estado, que a deve
garantir mediante políticas sociais e econômicas que visem à redução do
risco de doença e de outros agravos. O direito à saúde rege-se pelo
princípio da universalidade e da igualdade de acesso às ações e serviços
que a promovem, protegem e recuperem. O SUS, integra uma rede
regionalizada e hierarquizada de ações e serviços da saúde, constitui o
meio pelo qual o Poder Público cumpre seu dever na relação jurídica de
saúde que tem no polo ativo qualquer pessoa e comunidade, já que o direito
à promoção e à proteção da saúde é também um direito coletivo (SILVA,
2006, p. 402).

A judicialização da saúde manifesta-se pelo pedido individual realizado pelo cidadão, por meio de um advogado público ou privado, requerendo acesso a um medicamento e/ou tratamento que the foi negado em esfera administrativa pelo sistema público.

O caminho do Poder Judiciário para garantia do acesso aos medicamentos iniciou-se na década de $90 \mathrm{com}$ as demandas para medicamentos antirretrovirais e a participação de vários atores da sociedade civil organizada juntamente com as agências de cooperação internacional junto ao Poder Público. Esse movimento resultou em políticas públicas de proteção ao direito à saúde dos indivíduos com HIV/AIDS (TERRAZAS, 2014, p.109).

O direito à saúde deve ser efetivado por meio de políticas públicas que garantam a igualdade e que se destinam à melhoria das condições de vida e saúde da população. Os direitos fundamentais têm duas dimensões: objetiva e subjetiva. $\mathrm{Na}$ objetiva trata-se dos conteúdos que a norma do direito insere aos ordenamentos jurídicos estatais. Na subjetiva diz respeito à identificação dos direitos e deveres, prestações ou encargos (RIOS, 2009). 
A saúde dispõe de características que the concedem contornos de direito subjetivo público, possibilitando que cidadãos entrem com uma ação junto ao Poder Judiciário para exigir do Estado a adoção ou rejeição de medidas concretas em favor da saúde. Assim, o cidadão se reconhece como sujeito desse direito e busca efetiválo por meio de processo junto ao Judiciário (TERRAZAS, 2014, p.111).

O fenômeno da judicialização da saúde também pode ser visto como um problema, pois abarrota os tribunais com demandas e compromete parte significativa dos orçamentos da saúde (BARROSO, 2011). Uma das grandes críticas a esse fenômeno no Brasil é que o mesmo tem sido reduzido apenas ao fornecimento de medicamento pelo Poder Público aos cidadãos. Mas há outras demandas judiciais para efetivação do direito a procedimentos cirúrgicos, transplantes, vagas em hospitais, leitos em Unidade de Terapia Intensiva (UTI), alimentos, entre outros. Todavia, a grande demanda está restrita à solicitação de medicamentos (PEPE, 2010).

Os fundamentos e alternativas legais para que o cidadão proponha ações judiciais com o objetivo de obter medicamentos e outros serviços de saúde, permitem uma reflexão sobre este fenômeno. Marques (2005) aponta que grande parte dos que procuram o Poder Judiciário o fazem individualmente e os pedidos estão sendo deferidos pelos magistrados com fundamento, apenas, na prescrição médica.

Além disso, a prescrição médica vem sendo problematizada em vários estudos (BARROS, 2004; BARROS e JOANY, 2002; BRASIL, 2005) em que destacam a influência da indústria farmacêutica nas prescrições e o poder do profissional médico.

Percebe-se que são crescentes as demandas judiciais no Brasil, com ênfase ao acesso a medicamentos não fornecidos pelo SUS, procedimentos e insumos de saúde, o que representa um avanço ao efetivo exercício da cidadania, pois garante que o Estado cumpra com as decisões judiciais favoráveis, em que pese o impacto significativo nos gastos públicos na questão da saúde.

As ações judiciais são uma forma que os cidadãos encontram para garantir seus direitos, sendo, portanto, legítima uma ação judicial que vise a obrigar o Estado 
a fornecer um medicamento e insumos contemplados em suas políticas públicas e não disponíveis no SUS, visando, assim, a garantia de um direito fundamental.

Para Pepe (2010), as ações judiciais ajuizadas para garantia de direitos do cidadão como "judicialização" são um modo de desqualificar a atuação judicial, pressupondo que o Poder Judiciário está interferindo indevidamente na atuação do Poder Executivo. Nessa perspectiva, observa-se que há um processo de judicialização excessiva, que se demonstra pelo aumento de decisões que condenam o Poder Público ao pagamento de tratamentos ainda sem comprovação cientifica e transfere ao gestor local a responsabilidade da decisão de aplicação de recursos que, muitas das vezes, contradiz o princípio da equidade em saúde e o acesso à assistência à saúde de qualidade.

Além disso, verifica-se que alguns cidadãos se aproveitam da judicialização da saúde para obter regalias nos serviços fornecidos pelo SUS, pois o seu excesso gera, como consequência, uma grande repercussão nos recursos públicos e, muitas vezes, descaracteriza a igualdade de acesso à saúde pública por todos.

Barroso (2011) estabelece que:

Em muitos casos, o que se revela é a concessão de privilégios a alguns jurisdicionados em detrimento da generalidade da cidadania, que continua dependente das políticas universalistas implementadas pelo Poder Executivo (BARROSO, 2011, p. 4).

Ressalta-se que apesar da importância do Poder Judiciário como guardião da Constituição e dos direitos fundamentais, ele não pode induzir à "absolutização do direito à saúde" (PSCHEIDT, 2014, p.17) desorganizando o sistema, resultando na provocação do princípio da isonomia, haja vista se tratar de um direito misto: é fundamental originário, uma vez garantido pela Constituição Federal de 1988, mas é também derivado, que disciplinado por legislação infraconstitucional. Sem dúvida, percebe-se que a judicialização excessiva do acesso à saúde compromete o Sistema Único de Saúde. 


\section{MÉTODOS}

\subsection{ABORDAGEM QUALI-QUANTITATIVA}

Para verificar neste estudo as percepções de atores do Sistema de Justiça quanto à judicialização do acesso às fórmulas nutricionais e o direito à alimentação no Sistema Único de Saúde foi utilizada a abordagem quali-quantitativa. Para Simioni et al (1997), a escolha metodológica deve estar baseada no recorte da realidade de cada pesquisa, bem como na natureza do problema a ser estudado.

Segundo Lefèvre e Lefèvre (2003), a abordagem quali-quantitativa possibilita que os fenômenos sejam apreendidos de forma integrada, viabilizando tanto o aprofundamento do significado do comportamento individual e grupal quanto à quantificação do fenômeno.

Além disso, na pesquisa qualitativa, a matéria prima é composta pelos depoimentos obtidos nas entrevistas com indivíduos mensageiros das representações sociais (LEFÈVRE, 2000). O que se pretende com a pesquisa qualitativa é a recuperação da "fala do social", ou seja, os discursos que têm como emissores os grupos, coletividades, classes e extrato social.

A fala do Sistema de Justiça será resgatada por meio do que Lefèvre et al (2000) denomina de Discurso do Sujeito Coletivo (DSC) que será detalhado mais adiante.

\subsubsection{Pesquisa Exploratória}

Conforme Gil (1996), fortalecer, esclarecer e modificar conceitos e ideias com vistas à formulação de problemas mais preciosos ou hipóteses pesquisáveis para estudos posteriores são os propósitos das pesquisas exploratórias.

Para Piosevan e Temporini (1995), a pesquisa exploratória tem como principal finalidade buscar o conhecimento do repertório popular de respostas e este pode relacionar-se tanto ao conhecimento, crença e opinião como à atitude, aos valores e à conduta. 


\subsection{TIPO DE ESTUDO}

Estudo exploratório e descritivo com abordagem quali-quantitativa, realizado por meio de entrevista semiestruturada.

\subsection{LOCAL DO ESTUDO}

As entrevistas semiestruturadas foram realizadas presencialmente na cidade de Brasília/Distrito Federal e São Paulo. Os participantes dos estados de Santa Catarina, Rio Grande do Sul e Mato Grosso foram entrevistados por telefone. Todas as entrevistas foram realizadas pela própria pesquisadora e gravadas em equipamento digital com consentimento dos participantes.

Nas entrevistas presenciais o Termo de Consentimento Livre e Esclarecido (TCLE) foi lido juntamente com o entrevistado, assinado e entregue uma cópia para o entrevistado. Para as entrevistas realizadas por telefone, o TCLE foi enviado por correio eletrônico e devolvido devidamente assinado.

\subsection{POPULAÇÃO DO ESTUDO}

A escolha dos atores participantes desta pesquisa deu-se com base na identificação de informantes no banco de dados do Programa de Direito Sanitário (PRODISA) da Fundação Oswaldo Cruz (FioCruz) de Brasília. Foram selecionados aqueles que possuíam experiências, informações e percepções sobre o tema do estudo no processo de trabalho. Desta forma, foram identificados:

- dois defensores da Defensoria Pública;

- três juízes federais;

- um juiz do Tribunal de Justiça do Estado;

- um subprocurador-geral da República do Ministério Público Federal;

- um promotor de justiça do Ministério Público Estadual;

- um procurador estadual;

- dois advogados da União.

Os representantes do Sistema de Justiça que aceitaram participar deste estudo foram informados previamente. Foram esclarecidos os objetivos e a relevância da pesquisa no campo da saúde pública. $\mathrm{O}$ sigilo e anonimato foram 
garantidos aos participantes mediante a apresentação do TCLE, oferecido no contato com os entrevistados.

\subsection{INSTRUMENTO DE COLETA DE DADOS}

A entrevista é definida por Gil (1996) como uma técnica na qual o investigador apresenta-se ao investigado e lhe formula perguntas, a fim de obter dados que interessem à investigação.

A entrevista semiestruturada combina perguntas fechadas (ou estruturadas) e abertas, na qual o entrevistado tem a possibilidade de discorrer sobre o tema proposto, sem respostas ou condições prefixadas pelo pesquisador (MINAYO, 1992).

Segundo Trivinos (1987), a entrevista do tipo semiestruturada, em pesquisa qualitativa, é um dos principais meios de que o pesquisador dispõe para realização de coleta de dados. Ao mesmo tempo em que valoriza a presença do investigador, oferece todas as perspectivas possíveis para que o informante alcance a liberdade e espontaneidade necessárias, enriquecendo a investigação.

A entrevista semiestruturada foi composta de cinco perguntas norteadoras, listadas a seguir:

1) A alimentação é um direito garantido a todos brasileiros na Constituição. Em sua opinião, quais as responsabilidades do Poder Executivo para garantia desse direito?

2) Algumas pessoas possuem necessidades alimentares especiais em que são prescritas fórmulas nutricionais industrializadas para alimentação. A judicialização do SUS para acesso a essas fórmulas tem se tornado crescente. $\mathrm{O}$ (a) senhor(a) recebe esse tipo de demanda no seu trabalho? Como realiza a análise para a tomada de decisão desses casos?

3) Por se tratar de alimentos, o(a) senhor(a) considera que a análise dos processos de fórmulas nutricionais pode ser diferenciada dos processos de solicitação de medicamentos? Por quê? 
4) O que o senhor(a) identifica como possíveis causas da judicialização para acesso às fórmulas nutricionais no SUS?

5) O que o Poder Judiciário pode colaborar para resolução desses problemas?

Foi explicado aos entrevistados o conceito de fórmulas nutricionais, bem como, necessidades alimentares especiais.

\subsubsection{Coleta de Dados}

Os participantes do Sistema de Justiça foram contatados previamente pela pesquisadora e foram apresentados aos objetivos e à relevância do tema para a saúde pública.

As entrevistas foram realizadas no período de abril a agosto de 2015 . Os discursos das entrevistas foram registrados por meio de um mini gravador de voz digital da marca Sony ${ }^{\circledR}$. A duração de cada entrevista variou entre 20 a 60 minutos. Não houve, por parte dos representantes do Sistema de Justiça, qualquer objeção ao uso do gravador, tendo os discursos fluído naturalmente.

Antes da aplicação do questionário semiestruturado foram coletados dados quantitativos para fins de caracterização dos entrevistados.

\subsection{TÉCNICAS DE ANÁLISE DOS DADOS}

Para a análise dos dados utilizou-se a técnica do Discurso do Sujeito Coletivo (DSC), uma vez que ela dá voz aos indivíduos e é uma das possibilidades de análise de dados qualitativos em que está sempre envolvida a questão dos significados (LEFÈVRE et al, 2000; 2003). Foram utilizadas três figuras metodológicas: Ideia Central (IC), as Expressões-Chave (E-Ch) e o Discurso do Sujeito Coletivo (DSC).

A Ideia Central pode ser entendida como a síntese do conteúdo discursivo explicitado pelos sujeitos, estando presentes nas afirmações, negações e nos juízos de valor a respeito da realidade institucional, bem como no contexto social no qual os sujeitos estão envolvidos (SIMIONI et al, 1997; LEFÉVRE et al, 2000).

Os trechos selecionados nos discursos que servem para ilustrar as Ideias Centrais são definidos como Expressões-Chave. A literalidade dos depoimentos 
deve ser aqui resgatada, sendo consideradas uma espécie de prova-discursivoempírica da verdade das Ideias Centrais.

O Discurso do Sujeito Coletivo é uma estratégica metodológica que objetiva tornar mais clara uma representação social. É uma forma discursiva de apresentação e de tratamento dos depoimentos que compõem o substrato de uma representação social. Ao final da análise, espera-se que o discurso de todos seja o discurso de um só.

\subsubsection{Organização dos Discursos}

Para a análise dos conteúdos das entrevistas, que foram previamente transcritas na sua integralidade, e organização dos discursos, utilizou-se o software QualiquantiSoft (2009). Esse software favoreceu a análise e organização dos discursos na medida em que foram organizados e listados os depoimentos, facilitando o trabalho de identificação das Ideias Centrais adequadas às ExpressõesChave, sendo os antecessores do Discurso do Sujeito Coletivo.

A técnica consiste basicamente em analisar o material verbal coletado em pesquisas que tem depoimentos como sua matéria prima, extraindo-se de cada um destes depoimentos as Ideias Centrais ou Ancoragens e as suas correspondentes Expressões Chave com as Ideias Centrais/Ancoragens e Expressões Chave semelhantes compõe-se um ou vários discursos-síntese que são os Discursos do Sujeito Coletivo.

Segundo os autores da metodologia a utilização desta técnica possibilita resgatar o sentido das opiniões das coletividades e formar os DSC, constituídos num processo composto de três operações realizadas sobre esse material assim descritas:

- Expressões-Chave (E-Ch): trechos de cada depoimento verbal dos entrevistados, e que melhor descrevem o seu conteúdo.

- Ideias Centrais (IC): descrevem os sentidos presentes nos depoimentos, tanto individuais quanto nos conjuntos de depoimentos, que apresentam sentido semelhante ou complementar. 
- Ancoragens (AC): descrevem as ideologias, os valores e as crenças presentes nos depoimentos, individuais ou de um conjunto destes, sob a forma de afirmações genéricas destinadas a enquadrar situações particulares. De acordo com esta metodologia, somente quando os depoimentos apresentam marcas discursivas dessas afirmações genéricas, existirão AC.

O Discurso do Sujeito Coletivo (DSC), consiste na reunião das E-Ch presentes nos depoimentos apresentados, e que possuem IC e/ou AC com sentido semelhante ou complementar (SCHIAVO, 2007 apud COSTA, 2013). Com a transcrição das entrevistas, os conteúdos foram analisados individualmente e identificadas as Expressões Chave e Ideias Centrais para cada resposta dada do entrevistado.

Ao fim das transcrições e leituras individuais iniciou-se a inserção das respostas, Expressões Chave e Ideias Centrais no sistema do software Qualiquantisoft que auxiliou no processo de codificação e análise.

\subsection{ASPECTOS ÉTICOS}

Para o desenvolvimento da pesquisa foram considerados, em todas as suas etapas, os princípios éticos fundamentais que norteiam a pesquisa envolvendo seres humanos, descritos e estabelecidos pela Resolução do Conselho Nacional de Saúde № 466 de 2012.

Para dar início a sua execução, o presente projeto foi submetido e aprovado pela Comissão de ética e pesquisa da Universidade de Brasília (UnB) - Parecer no 1.014.733 - (Apêndice D). 


\section{RESULTADOS E DISCUSSÃO}

\subsection{PERFIL DOS ENTREVISTADOS}

Foram entrevistados 11 representantes do Sistema de Justiça, sendo 2 da Advocacia-Geral da União (AGU), 2 da Defensoria Pública, 2 do Ministério Público (MP), 4 da Magistratura e 1 da Procuradoria Geral do Estado, com idade média de 43 anos, que variou entre 29 e 54 anos.

Tabela 1 - Caracterização dos sujeitos, Brasília, 2016

\begin{tabular}{lcc}
\hline Variável & $\mathrm{N}$ & $\%$ \\
\hline Sexo & 1 & 9,0 \\
Feminino & 10 & 90,9 \\
Masculino & 43,1 & \\
\hline Idade (média em anos) & & \\
\hline Instituição & 2 & 18,1 \\
AGU & 2 & 18,1 \\
Defensoria & 4 & 36,3 \\
Judiciário & 2 & 18,1 \\
Ministério Público & 1 & 9,0 \\
Procuradoria Geral do Estado & & \\
Escolaridade & 2 & 18,1 \\
Graduação & 5 & 45,4 \\
Especialização lato sensu & 3 & 27,2 \\
Mestrado & 1 & 9,0 \\
Doutorado & & \\
Tempo de atuação na área da & & \\
saúde (anos) & 3 & 27,2 \\
Até 1 & 4 & 36,3 \\
2 a 5 & 4 & 36,3 \\
Mais de 5 & 8,5 & \\
Tempo médio & & \\
\hline
\end{tabular}

Dos entrevistados, $91 \%$ eram do sexo masculino e $9 \%$ do sexo feminino. Esta predominância também foi percebida por Melo et al (2005), que demonstrou que há baixa participação das mulheres no Sistema Judiciário, sendo em média de $30 \%$.

Segundo o último Censo dos Magistrados realizado, 64\% dos magistrados são do sexo masculino (BRASIL, 2014). Já no Ministério Público Federal, os homens 
correspondem a $71,6 \%$, enquanto a participação feminina é de $28,4 \%$ (CASTILHO e SADEK, 2010, p. 5).

No que se refere à idade, a média apresentada foi de 43 anos. Em estudo realizado por Castilho e Sadek (2010, p.5), a média de idade dos procuradores foi de 36 anos, enquanto a dos magistrados foi de 42 anos.

Quanto à escolaridade, 45\% dos entrevistados possuíam título de especialista lato sensu em alguma área do direito, 27\% eram mestres e $9 \%$ doutores, enquanto $18 \%$ apenas possuíam a graduação em direito. Dados semelhantes foram publicados pelo Conselho Nacional de Justiça (CNJ), em que 47\% dos magistrados apresentaram pós-graduação lato sensu, 12\%, mestrado e 3,3\%, doutorado (BRASIL, 2014). Quanto ao tempo de experiência na área da saúde, 36\% possuíam até 5 anos e 36\% acima de 5 anos. Verificou-se que 27\% dos entrevistados apresentaram pouco tempo de experiência (até 1 ano) - Tabela 1.

\subsection{DISCURSO DO SUJEITO COLETIVO}

Por meio da utilização da metodologia do Discurso do Sujeito Coletivo foram identificadas as ideias centrais e expressões-chaves presentes nos discursos dos atores da pesquisa. E, assim, foi construído o DSC relacionado a cada Ideia Central identificada. Abaixo, serão especificados as ideias centrais e os discursos dos sujeitos coletivos a elas relacionados. Nos apêndices $E$ ao I encontram-se as tabelas com as expressões-chave identificadas, que permitiram a identificação de cada ideia central de cada pergunta norteadora.

Pergunta 01: A alimentação é um direito garantido a todos brasileiros na Constituição. Em sua opinião, quais as responsabilidades do Poder Executivo para garantia desse direito?

Para essa questão foram construídas seis categorias de acordo com as ideias centrais. Para cada ideia central foi construído um DSC. 
Quadro 1 - Ideias Centrais (IC) relacionadas à Pergunta nำ (P01)

\begin{tabular}{|c|c|c|}
\hline P01- ICA & 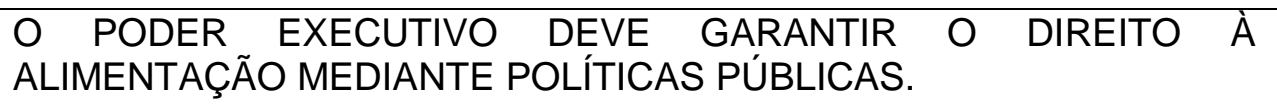 & $35 \%$ \\
\hline P01-ICB & $\begin{array}{l}\text { O PODER JUDICIÁRIO ESTÁ SE IMISCUINDO NO PAPEL DO } \\
\text { EXECUTIVO. }\end{array}$ & $20 \%$ \\
\hline P01-ICC & $\begin{array}{l}\text { O ESTADO DEVE SER LIBERAL E GARANTIR O DIREITO À } \\
\text { ALIMENTAÇÃO APENAS NO SEU BÁSICO. }\end{array}$ & $10 \%$ \\
\hline P01-ICD & $\begin{array}{l}\text { O DIREITO À ALIMENTAÇÃO É GARANTIDO FORMALMENTE, NÃO } \\
\text { SE CONCRETIZOU. }\end{array}$ & $5 \%$ \\
\hline P01-ICE & $\begin{array}{l}\text { O DIREITO À ALIMENTAÇÃO NA PERSPECTIVA DA SEGURANÇA } \\
\text { ALIMENTAR E NUTRICIONAL. }\end{array}$ & $20 \%$ \\
\hline P01-ICF & $\begin{array}{l}\text { PAPEIS DISTINTOS DOS PODERES DO ESTADO NA FORMULAÇÃO } \\
\text { E IMPLEMENTAÇÃO DE POLIITICAS. }\end{array}$ & $10 \%$ \\
\hline
\end{tabular}

Fonte: SILVA, 2016.

A figura 1 apresenta o resultado quantitativo com a frequência das ideias centrais relativas à pergunta $n^{0} 1$.

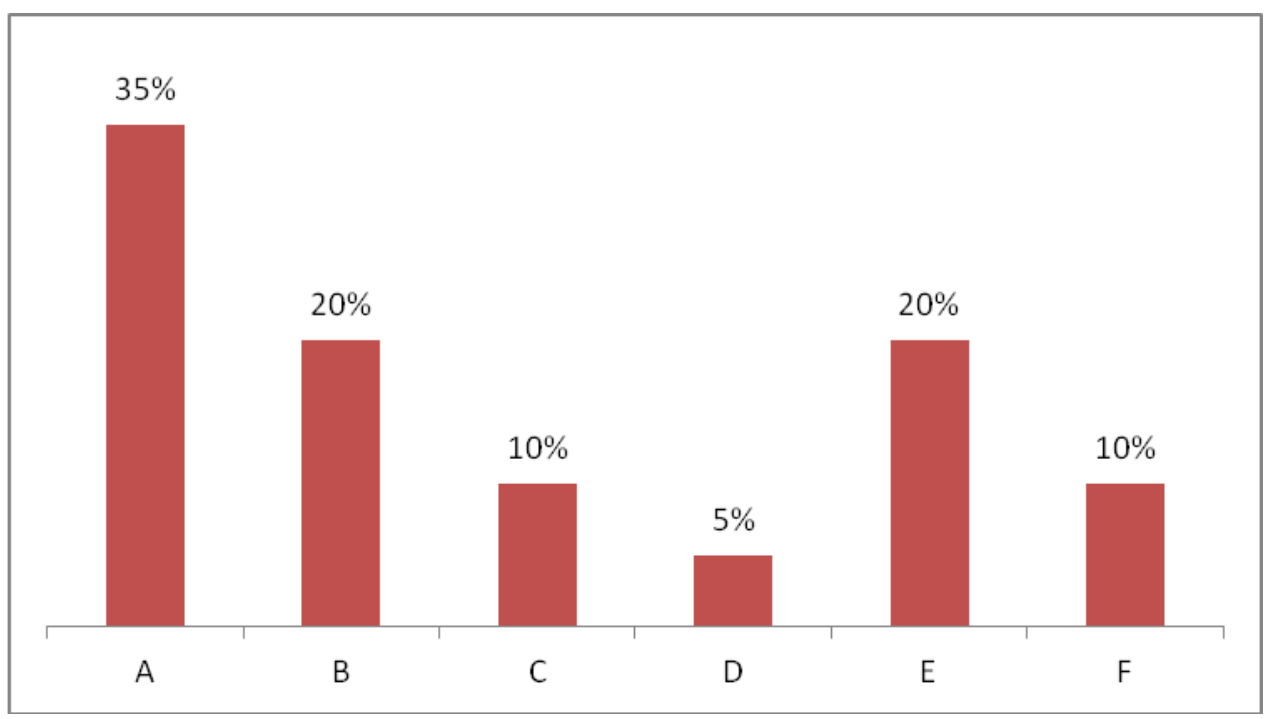

Figura 1 - Incidência das Ideias Centrais: pergunta $\mathrm{n}^{\circ} \mathrm{1}$

\section{Ideia Central A (P01 - ICA): O Poder Executivo dever garantir o direito à alimentação mediante políticas públicas.}

Discurso do Sujeito Coletivo:

A alimentação é prevista como um direito fundamental e um dever do Estado na Constituição. Deve ser implementada por meio de políticas públicas que devem ser organizadas para garantir a alimentação em todos os níveis da Federação, principalmente, nos municípios, com a ação supletiva dos Estados e da União, visando atingir o básico e o indispensável, não para garantir lagosta e nem camarão 
na mesa de todos.

Ideia Central B (P01 - ICB): O Judiciário está se imiscuindo do papel no Poder Executivo.

Discurso do Sujeito Coletivo:

Não é atribuição do Poder Judiciário alterar o planejamento do gestor de saúde, que já é objeto de controle externo dos conselhos. Quem determina as políticas é o Poder Executivo, e muitas vezes, o Legislativo. O Poder Judiciário não pode criar políticas públicas de saúde e alimentação.

Ideia Central C (P01 - ICC): 0 Estado deve ser liberal e garantir o direito à alimentação apenas no seu básico.

Discurso do Sujeito Coletivo:

O Estado tem um papel social, mas, no caso da alimentação, tem que preponderar a livre iniciativa. Diante desses pressupostos, o Estado deve ofertar condições de educação e de alimentação mínimas e a grande parte das pessoas deverá desenvolver conforme sua capacidade, trabalho e livre iniciativa. Apenas para os casos onde há hipossuficiência, o Estado deve garantir alimentos.

Ideia Central D (P01 - ICD): O direito à alimentação é garantido formalmente, não se concretizou.

Discurso do Sujeito Coletivo:

A alimentação é um direito garantido formalmente, porque materialmente há muitos famélicos e subnutridos no país, em vista dos problemas com a divisão de renda.

Ideia Central E (P01 - ICE): 0 direito à alimentação na perspectiva da Segurança Alimentar e Nutricional.

Discurso do Sujeito Coletivo:

A alimentação prevista na Constituição é voltada para a Segurança Alimentar do que à alimentação no viés de saúde. Mas há casos de judicialização da alimentação como se fosse direito à saúde, quando o Estado tem a obrigação de fornecer às pessoas que possuem algum tipo de alergia, principalmente ao leite de vaca. $O$ direito à alimentação está sendo focado como saúde, como é o caso da alimentação 
enteral.

\section{Ideia Central F (P01 - ICF): Papeis distintos dos poderes do Estado na formulação e implementação de políticas públicas.}

Discurso do Sujeito Coletivo:

A responsabilidade do Poder Legislativo é regulamentar a Constituição de modo a propiciar um arcabouço legal, cujo objetivo seja dar legalidade ao direito constitucionalmente garantido. A responsabilidade do Poder Executivo está vinculada com as questões de execução orçamentária e financeira e das leis emanadas do Legislativo para dar materialidade ao direito à alimentação. $A$ responsabilidade do Poder Judiciário é mediar e decidir sobre as controvérsias existentes entre o Estado, que tem obrigação de garantir o direito por intermédio de políticas públicas ao cidadão, que necessita da boa alimentação.

O objetivo da pergunta 01 foi conhecer a percepção do Sistema de Justiça sobre o direito à alimentação, bem como o papel do Poder Executivo na efetivação desse direito.

A ideia central A (P01 - ICA) foi a mais frequente e evidencia que o discurso do Sistema de Justiça é coerente com o texto da Constituição Federal de 1988, reconhecendo que a efetivação do direito à alimentação deve ser por meio de políticas públicas.

As políticas públicas constituem o meio pelo qual o Estado, representado por suas instituições públicas, organiza-se para atender as necessidades da população. Dessa forma,

(...) as políticas públicas representam as características e valores de um determinado governo, traduzindo a forma como este usa as instituições públicas para se relacionar com a sociedade e garantir seus direitos (CONSEA, 2010, p. 214).

Nesse contexto, e corroborando com a P01- ICA, o Sistema Nacional de Segurança Alimentar e Nutricional (SISAN), instituído pela Lei № 11.346 de 2006, conhecida como Lei Orgânica de Segurança Alimentar e Nutricional (LOSAN), regulamentada pelo Decreto no 7.272, de 2010, visa promover à Segurança Alimentar e Nutricional (SAN) e assegurar o Direito Humano à Alimentação Adequada (DHAA) a todos os brasileiros (BRASIL, 2006; BRASIL, 2010b). 
Desde a sua criação, avanços legais e institucionais têm garantido a sua construção como estrutura responsável pela implementação e gestão participativa da Política Nacional de Segurança Alimentar e Nutricional (PNSAN) em âmbito federal, estadual e municipal.

O Governo Federal apoia financeiramente os estados e municípios que fizeram adesão ao SISAN para o funcionamento de suas Câmaras Intersetoriais/Intersecretarias e de seus Conselhos de Segurança Alimentar e Nutricional. Atualmente todas as Unidades Federativas aderiram ao SISAN e realizam suas conferências. Ressalta-se que o Ministério do Desenvolvimento Social e Combate à Fome (MDS) preside e é responsável pela Secretaria Executiva da Câmara Intersetorial de Segurança Alimentar e Nutricional (CAISAN), garantindo o seu funcionamento.

A PNSAN representa, no âmbito do Poder Executivo, a política pública que orienta a organização intersetorial para garantir os meios necessários à efetivação do direito à alimentação. Ou seja, induz a responsabilização de diferentes setores do Poder Executivo, por meio de suas políticas e programas, a efetivar ações relacionadas aos diferentes âmbitos da SAN envolvidos na garantia da alimentação adequada e saudável para a população. Essa indução tem se concretizado por meio do Plano de Segurança Alimentar e Nutricional (PLANSAN), que é um documento que pretende assegurar o direito humano à alimentação adequada, além de estimular a integração dos esforços entre governo e sociedade civil para promover acompanhamento, monitoramento e avaliação da segurança alimentar e nutricional no País. Para garantir a implantação do plano, suas metas e objetivos estão previstos no Plano Plurianual 2012-2015 (PPA). O documento deverá ser revisado a cada dois anos, conforme determina o Decreto (BRASIL, 2010b). A proposta é que estados e municípios façam a adesão ao SISAN e elaborem seus planos locais de segurança alimentar e nutricional.

$\mathrm{Na}$ arena intersetorial da SAN, o setor saúde tem historicamente assumido importante papel. Conforme apontam Alves e Jaime:

As consequências da inseguranca alimentar e nutricional da populacão, a exemplo da desnutrição e carências nutricionais especificas, recaem sobre o setor saúde e tem feito com que historicamente este setor tenha incorporado a responsabilidade de políticas e programas de alimentação e nutrição no Brasil. No entanto, a garantia da Segurança Alimentar e 
Nutricional exige uma conjunção de políticas públicas, dentre as quais a Política Nacional de Alimentação e Nutrição do SUS tem papel fundamental (2014, p. 4333).

A Política de Alimentação e Nutrição (PNAN) publicada em 1999 e revisada em 2011 tem como atual propósito:

A melhoria das condições de alimentação, nutrição e saúde da população
brasileira, mediante a promoção de práticas alimentares adequadas e
saudáveis, a vigilância alimentar e nutricional, a prevenção e o cuidado
integral dos agravos relacionados à alimentação e nutrição (BRASIL, 2012b,
p. 21).

A PNAN tem por pressupostos os direitos à saúde e à alimentação e é orientada pelos princípios doutrinários e organizativos do SUS, aos quais se somam os princípios: alimentação como elemento de humanização das práticas de saúde; respeito à diversidade e à cultura alimentar; fortalecimento da autonomia dos indivíduos; determinação social e a natureza interdisciplinar e intersetorial da alimentação e nutrição; e SAN com soberania (ALVES e JAIME, 2014). Além disso, reconhece como demanda para a atenção nutricional no SUS o cuidado aos indivíduos com necessidades alimentares especiais:

As necessidades alimentares especiais estão aqui referidas como as
necessidades alimentares, sejam restritivas ou suplementares, de
indivíduos portadores de alteração metabólica ou fisiológica que cause
mudanças, temporárias ou permanentes, relacionadas à utilização biológica
de nutrientes ou a via de consumo alimentar (enteral ou parenteral).
Exemplos: erros inatos do metabolismo, doença celíaca, HIV/AIDS,
intolerâncias alimentares, alergias alimentares, transtornos alimentares,
prematuridade, nefropatias, etc (BRASIL, 2012b, p. 74).

Com relação ao objeto desse estudo, a PNAN sinaliza que "deverão ainda ser normatizados os critérios para o acesso a alimentos para fins especiais de modo a promover a equidade e a regulação no acesso a esses produtos" (BRASIL, 2012b, p. 30). Porém, verifica-se que não há nenhuma normativa em âmbito nacional que propicie o acesso a alimentos para fins especiais no âmbito do SUS. Faz-se necessária a elaboração de protocolos, manuais e normas técnicas que orientem a organização do acesso aos alimentos para fins especiais no âmbito do SUS. Essa falta de normatização pode contribuir para o crescimento da judicialização e a tomada de decisões equivocadas pelo Poder Judiciário.

Ainda é exposto pelos entrevistados na P01-ICA que "políticas públicas devem ser organizadas para garantir a alimentação em todos os níveis da Federação, principalmente nos municípios, com a ação supletiva dos estados e da 
União, visando a atingir o básico e o indispensável, não para garantir lagosta e nem camarão na mesa de todos". Mas, conforme mencionado no referencial teórico desse trabalho, o Direito Humano à Alimentação Adequada (DHAA) tem duas dimensões, o direito de estar livre da fome e da má nutrição e o direito à alimentação adequada. Esse direito começa pela luta contra a fome, mas, caso limite-se a isso, não estará sendo plenamente realizado. Os seres humanos necessitam de muito mais do que atender suas necessidades de energia ou de ter uma alimentação nutricionalmente equilibrada. Nesse sentido, o DHAA não deve - e não pode - ser interpretado em um sentido estrito ou restritivo, ou seja, que o condiciona ou o considera como "recomendações mínimas de energia ou nutrientes".

Assim, o entendimento de que as políticas públicas devem visar ao básico e ao indispensável para sobrevivência vai contra o conceito de DHAA. As pessoas com necessidades alimentares especiais necessitam de acesso aos alimentos e informação sobre os alimentos adequados para sua necessidade. Já aqueles que têm recursos para comprar seus alimentos precisam de informação adequada para fazerem escolhas saudáveis e seguras (por exemplo, rótulos confiáveis e de fácil compreensão). Ou seja, ainda que todos esses grupos tenham características em comum, em determinadas ocasiões requerem ações específicas para garantir seu direito (LEÃO e RECINE, 2011).

A P01 - ICC refere que o Estado deve garantir condições mínimas para o direito à alimentação, o restante, as pessoas deverão desenvolver conforme a livre iniciativa. Apenas nos casos de hipossuficiência, deve ser garantido integralmente. Este achado contradiz com o Estado Social que deve interferir na vida de todos os cidadãos de forma positiva, implementando direitos.

Os direitos sociais exigem do Estado um papel prestacional para diminuir as desigualdades sociais e proporcionar condições dignas de vida, protegendo os mais fracos (COUTINHO, 1997). Assim, o argumento de garantir o direito à alimentação apenas nos casos de hipossuficiência está incoerente com os pressupostos das políticas sociais.

Conforme a P01- ICE é evidente que a percepção do conceito de Segurança Alimentar e Nutricional (SAN) de forma como está concebido no Brasil e expresso em legislação especifica (Lei 11.346/2006) está distante da realidade do processo 
de trabalho do Sistema de Justiça, principalmente dos magistrados. Há um entendimento de que a SAN não é aplicada nos processos judiciais onde há solicitação de fórmulas nutricionais, pois consideram apenas os aspectos clínicos (de saúde).

A SAN tem duas dimensões: alimentar e nutricional, sendo compreendida como "a realização do direito de todos ao acesso regular e permanente a alimentos de qualidade, em quantidade suficiente, sem comprometer 0 acesso a outras necessidades essenciais, tendo como base práticas alimentares promotoras de saúde que respeitem a diversidade cultural e que sejam ambiental, cultural, econômica e socialmente sustentáveis" (BRASIL, 2006). Alves e Jaime (2014) relatam que é comum relacionar as contribuições do SUS para a SAN apenas às ações de vigilância alimentar e nutricional, às ações de promoção da alimentação adequada e saudável e aos programas de prevenção de carências nutricionais. Mas, partindo da compreensão da interdependência entre saúde e SAN, todo o conjunto de ofertas do SUS para promoção e proteção da saúde, vigilância em saúde, prevenção, diagnóstico, tratamento e reabilitação de agravos e doenças, contribuem para a segurança alimentar e nutricional.

Portanto, a incompreensão do conceito de SAN fomenta a ideia de que o direito à alimentação deve ser aplicado de forma diferente no campo da SAN e da saúde e é refletida nas dificuldades do Sistema de Justiça quanto ao direito à alimentação. Delduque e Silva (2014) apontam no seu estudo que os tribunais e o Poder Judiciário não estão preparados para julgar ações em que o objeto material da demanda seja o direito à alimentação, tendo em vista as impropriedades no trato com a matéria, a ausência de pedidos de perícia e o tratamento como medicamento de um produto essencialmente alimentar.

Os processos judiciais que demandam alimentos demonstram que as questões sobre alimentação estão sempre relacionadas à saúde, principalmente ao diagnóstico clínico. Este discurso remete à possibilidade de despreparo do Sistema de Justiça em relação ao tema.

O papel do Poder Executivo é fomentar e executar as políticas públicas, mas observa-se que o Poder Judiciário exerce esse papel quando julga os pleitos em saúde. Essa afirmação está presente em 20\% dos discursos (P01-ICB). Na maioria 
dos processos, os juízes não solicitam maiores esclarecimentos para conceder medicamentos, fórmulas nutricionais e insumos ao cidadão, baseando-se apenas na prescrição médica e em documentos apresentados no início dos processos, além de não conferir as políticas públicas existentes no SUS.

Em sua pesquisa, Gomes e Amador (2014) verificaram que no momento em que as decisões judiciais para aquisição de determinados medicamentos e insumos se dão sem uma análise das alternativas terapêuticas incorporadas ao SUS, a política de saúde está sendo desconsiderada, acarretando prejuízos ao usuário e ao sistema.

Baptista et al (2009) retratam que o Poder Judiciário, ao atuar como árbitro e defensor dos direitos e exercer sua autonomia e isolamento, passa a ser questionado, pois encaminha decisões que, às vezes, colidem com a garantia do direito à saúde e prejudicam as políticas públicas de saúde.

Marques e Dallari (2007), em um estudo no qual analisaram como o sistema jurídico garante o direito social à assistência farmacêutica, verificaram que o Poder Judiciário não considerava a política pública de medicamentos. Suas decisões baseavam-se unicamente na afirmação do direito à saúde e à assistência farmacêutica como direitos integrais e universais dos cidadãos brasileiros contida no arcabouço legal (Constituição Federal e Lei Orgânica de Saúde).

Em estudo realizado pelo Ministério da Saúde em 2014 foi verificado que as demandas judiciais por fórmulas nutricionais tiveram aumento de mais de quatro vezes entre 2007 e 2013, sendo que 59,5\% dos processos não apresentavam comprovação diagnóstica (PEREIRA et al, 2014).

Percebe-se na P01 - ICE a clareza das reponsabilidades dos Poderes do Estado. Sabe-se que a clássica separação dos papeis dos Poderes dificulta 0 desempenho das atribuições estatais. Segundo Barbosa (2006), a interpenetração entre as funções exercidas para cada poder, garante a colaboração entre os poderes distintos. 
Pergunta 02: Algumas pessoas possuem necessidades alimentares especiais em que são prescritas fórmulas nutricionais industrializadas para alimentação. A judicialização do SUS para acesso a essas fórmulas tem se tornado crescente. $O(a)$ senhor(a) recebe esse tipo de demanda no seu trabalho? Como realiza a análise para a tomada de decisão desses casos?

Para essa questão foram construídas seis categorias de acordo com as ideias centrais. Para cada ideia central foi construída um DSC.

Quadro 2 - Ideias Centrais relacionadas à Pergunta ํㅡ 2

\begin{tabular}{|c|c|c|}
\hline P02-ICA & $\begin{array}{l}\text { SIM. VERIFICA SE HÁ PREVISÃO NA POLÍTICA PÚBLICA E } \\
\text { ENCAMINHA PARA AS ÁREAS TÉCNICAS. }\end{array}$ & $25 \%$ \\
\hline P02-ICB & $\begin{array}{l}\text { SIM. RECEBE, ANALISA E PROVOCA AS SECRETARIAS DE SAÚDE } \\
\text { COM PROCESSOS ADMINISTRATIVOS. }\end{array}$ & $25 \%$ \\
\hline P02-ICC & $\begin{array}{l}\text { PROCURA ENTENDER AS RAZÕES DOS GESTORES EM NÃO } \\
\text { CUMPRIR O DIREITO Á ALIMENTAÇÃO. }\end{array}$ & $12,5 \%$ \\
\hline P02-ICD & NÃO. & $12,5 \%$ \\
\hline & $\begin{array}{l}\text { NÃO HÁ REGIME JURÍDICO PARA ALIMENTAÇÃO, USA-SE O } \\
\text { DIREITO À SAÚDE. }\end{array}$ & \\
\hline P02-ICF & O JUDICIÁRIO NÃO RESPEITA A ANÁLISE TÉCNICA DO ESTADO. & $6,25 \%$ \\
\hline
\end{tabular}
Fonte: SILVA, 2016.

A figura 2 apresenta o resultado quantitativo com a frequência das ideias centrais relativas à pergunta $n^{\circ} 2$.

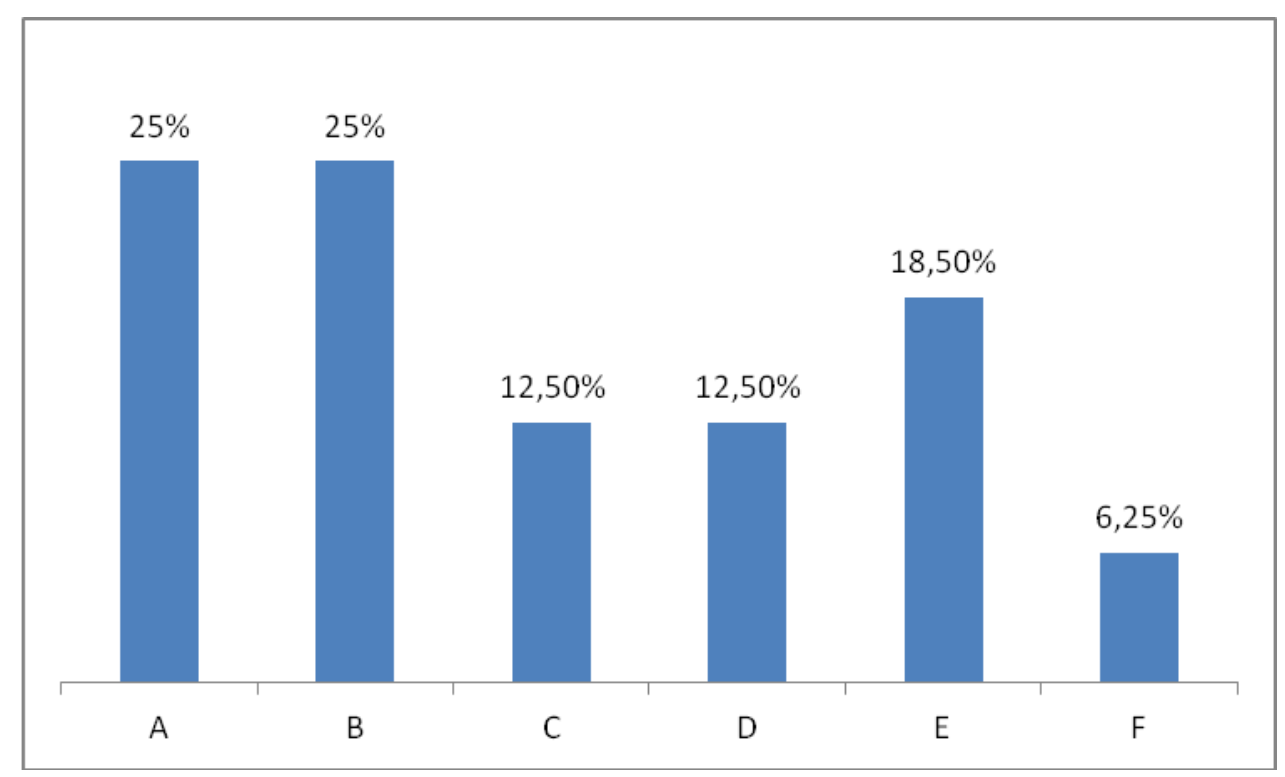

Figura 2 - Incidência das Ideias Centrais: pergunta $n^{\circ} 2$ 
Ideia Central A (P02 - ICA): Sim. Verifica se há previsão na política pública e encaminha para as áreas técnicas.

Discurso do Sujeito Coletivo:

Sim. Verifica se há política pública que abrange fórmulas nutricionais e, após análise, direciona para as áreas técnicas, para subsídio. O receituário médico é a única fonte diagnóstica.

Ideia Central B (P02 - ICB): Sim. Recebe, analisa e provoca as secretarias de saúde com processos administrativos.

Discurso do Sujeito Coletivo:

Sim. Procura-se resolver as demandas administrativamente, envolvendo os setores da secretaria de saúde responsáveis. Quando não há êxito no âmbito administrativo, provoca o Poder Judiciário.

Ideia Central C (P02 - ICC): Procura entender as razões dos gestores em não cumprir o direito à alimentação.

Discurso do Sujeito Coletivo:

Procura-se entender as razões do gestor de saúde, que eventualmente não estaria a cumprir esse direito. O não cumprimento ocorre por questões financeiras ou por inexistência de políticas públicas de alimentação e nutrição.

Ideia Central D (P02 - ICD):Não.

Discurso do Sujeito Coletivo:

Não.

Ideia Central E (P02 - ICE): Não há regime jurídico para alimentação, usa-se o direito à saúde.

Discurso do Sujeito Coletivo:

O Judiciário é provocado pelos indivíduos que não conseguem comprar as fórmulas nutricionais, pois apresentam custo elevado. Essa demanda é atribuída à saúde, pois o Judiciário julga diferentemente as ações de direito à saúde, tende a ser muito mais permissivo. Ainda que o direito à alimentação tenha resultado por emenda 
constitucional, ainda não se criou cultura de um regime jurídico especifico para a alimentação.

Ideia Central F (P02 - ICF): 0 Judiciário não respeita a análise técnica do Estado.

Discurso do Sujeito Coletivo:

A experiência mostra que o parecer técnico dos profissionais do SUS nos processos não é suficiente, o Judiciário entende que a prescrição particular é mais que satisfatória.

Nessa questão, o objetivo foi conhecer a percepção do Sistema de Justiça quanto ao assessoramento técnico na área de saúde para análise dos processos.

A frequência somada das categorias A e B (P02 - ICA/ICB) representam 50\% das opiniões dos entrevistados. Esses participantes recebem processos judiciais para fornecimento de alimentos, como fórmulas nutricionais, e solicitam subsídio técnico para análise desses processos. Nota-se nos discursos a importância das áreas técnicas para a tomada de decisão e o papel do Sistema de Justiça em fornecer o arcabouço jurídico.

Silva (2012) destaca que a incorporação de uma análise técnica e multiprofissional no discurso jurídico torna-se importante para o exercício da jurisdição que envolve questões de saúde. Em 2009, o $\mathrm{CNJ}^{14}$ recomendou o apoio técnico de profissionais de saúde na composição dos Núcleos de Assessoramento Técnico (NAT). Esse núcleo auxilia os magistrados na formação de um juízo de valor quanto à apreciação das questões clínicas apresentadas nas ações.

A P02 - ICA destaca que o receituário médico é a única prova diagnóstica presente nos pleitos para fornecimento de alimentos. Outros estudos também evidenciaram que o principal critério judicial para acesso a determinados medicamentos ou procedimentos, em geral, são os receituários médicos (ROMERO,

\footnotetext{
${ }^{14}$ Conselho Nacional de Justiça. Recomendação no 31, de 30 de março de 2010. Recomenda aos Tribunais a adoção de medidas visando a melhor subsidiar os magistrados e demais operadores do direito, para assegurar maior eficiência na solução das demandas judiciais envolvendo a assistência à saúde. Diario Justiça. $07 \quad$ abr $2010 . \quad$ Disponível em: <http://www.cnj.jus.br/images/stories/docs_cnj/recomendacoes/reccnj_31.pdf>.
} 
2008; VIEIRA e ZUCCI, 2007; MARQUES e DALLARI, 2007; SANT'ANA, 2009; PEPE et al, 2010).

Este posicionamento do Judiciário gera questionamentos sobre a legitimidade e competência técnica e/ou legal do poder judicial em decidir sobre o modo como a prestação estatal deve ser cumprida pelo Executivo da saúde. Sabe-se que tal deliberação é de competência do Poder Executivo, considerando as implicações orçamentárias e técnicas que envolvem a incorporação de tecnologias no SUS (MARQUES e DALLARI, 2007; SANT'ANA et al., 2011; VENTURA et al., 2010).

A P02 - ICB revela que o Sistema de Justiça procura resolver as demandas judiciais com atos administrativos que são reconhecidos como uma ferramenta que contribui para a diminuição da judicialização. Estudo realizado por Honorato (2014), no Distrito Federal, verificou o contrário do apresentado no P02- ICB. Foi verificado que atos administrativos dos gestores do SUS impactaram diretamente na judicialização da assistência farmacêutica e teve como consequência o aumento imediato das demandas judiciais.

Já a P02 - ICE apresenta uma informação relevante, em que não há um regime jurídico específico para o direito à alimentação, todas as ações que solicitam alimentos são tratadas no âmbito do direito à saúde. Contudo, a própria Constituição compreende que, para a garantia do direito à alimentação, são necessárias ações intersetoriais, mas os advogados, defensores e promotores estrategicamente julgam esses pleitos como direito à saúde, alegam que o Judiciário tem um "olhar" diferenciado para ações relacionadas à saúde.

Beurlen (2008) afirma que, mesmo não havendo um entendimento mais aprofundado do direito à alimentação, os Tribunais, somente pela compreensão de sua importância como valor moral, proferem decisões favoráveis, por exemplo, à obrigação do Poder Público de fornecer alimentação especial (ou fórmulas) para pessoas com determinados tipos de doenças.

Um estudo em São Paulo revelou que, judicialmente, o Estado é obrigado a fornecer itens para nutrição como sucos e bebidas à base de soja, água de coco, leite de vaca e de cabra in natura, adoçantes, achocolatados, óleo de soja, azeite de oliva, amido de milho e outras farinhas e mucilagens, além de feira semanal para 
aquisição de alimentos in natura. Esses itens são excluídos do rol da atuação do SUS, pois é competência de outros setores públicos, mas em se tratando de processo judicial em saúde, são exigidos do Estado e direcionados para a pasta da saúde (SIQUEIRA, 2015). Verifica-se que os limites e contornos dos direitos sociais, como saúde e alimentação não são claros. Para Delduque e Marques (2011), as soluções positivistas apresentadas pela aplicação da lei e do arcabouço normativo não são satisfatórias.

Tendo em vista que a presença de decisões para acesso às fórmulas nutricionais é uma constante no Judiciário (FINK et al, 2010; DELDUQUE e SILVA, 2014; PEREIRA et al, 2014), chama atenção o fato de que 12\% (P02 - ICD) dos entrevistados relataram não receber esse tipo de demanda. Tal afirmação pode estar relacionada ao fato de esses alimentos terem sido demandados em juízo como se fossem medicamentos, e garantidos em sentença, igualmente, como medicamentos, desconsiderando-se sua real qualidade de alimento (DELDUQUE e MARQUES, 2011).

$\mathrm{Na}$ P02 - ICC observa-se a preocupação de entender os processos, avaliando a justificativa dos gestores da saúde em não cumprir o que está sendo judicializado. O não cumprimento ocorre por questões financeiras e a falta de política pública de alimentação e nutrição. Interessante observar que, por parte do Sistema de Justiça, há o interesse de entender os motivos que levam o Executivo a negar os pleitos. Tal constatação não é coerente com os estudos recentes. Para maioria dos casos, os magistrados obrigam os gestores da saúde a fornecer os insumos demandados e ignoram o impacto orçamentário de uma decisão judicial (WANG, 2009; WANG, 2014).

Apesar da pequena frequência nas falas dos entrevistados, a P02 - ICF torna-se relevante ao expressar que os pareceres técnicos emitidos pelos profissionais de saúde do SUS não são suficientes e a avaliação final do profissional do sistema de saúde privado prevalece. Ventura et al. (2010) confirma que a prescrição médica é a única evidência utilizada pelo Poder Judiciário e não a compara com as ofertas oferecidas pelo SUS. Além disso, Sant'ana e colaboradores (2011), ao analisar as prescrições dos processos judiciais do estado do Rio de Janeiro, constataram que nenhum dos processos respeitou os preceitos de boas 
práticas de prescrição do SUS e mesmo assim foram deferidas, sem nenhuma exigência de adequação.

A P02- ICF é corroborada com outros autores que afirmam que o Poder Judiciário não respeita as políticas públicas de saúde. Para ele, questões políticas não podem regular ou preservar o exercício desse direito (MARQUES e DALLARI, 2007; MARQUES; MELO e SANTOS, 2011; VIEIRA e ZUCCHI, 2007).

Pergunta 03: Por se tratar de alimentos, o(a) senhor(a) considera que a análise dos processos de fórmulas nutricionais pode ser diferenciada dos processos de solicitação de medicamentos? Por quê?

Para essa questão foram construídas três categorias de acordo com as ideias centrais. Para cada ideia central foi construído um DSC.

Quadro 3 - Ideias Centrais relacionadas à Pergunta nํ 3

\begin{tabular}{|lllll|}
\hline P03-ICA & $\begin{array}{l}\text { SIM. AÇÕES JUDICIAIS DE ALIMENTOS COM PREMISSAS } \\
\text { FINANCEIRAS DEVEM SER ANALISADAS A PARTIR DA LÓGICA } \\
\text { DA ASSISTÊNCIA SOCIAL. }\end{array}$ & $9 \%$ \\
\hline P03-ICB & NÃO. GUARDAM COMPATIBILIDADE COM MEDICAMENTOS. & $45 \%$ \\
\hline P03-ICC & $\begin{array}{l}\text { SIM. OS CRITÉRIOS } \\
\text { DIFERENTES. }\end{array}$ & TÉCNICOS E & CIENTÍFICOS SÃO & $45 \%$ \\
\hline
\end{tabular}

Fonte: SILVA, 2016.

A figura 3 apresenta o resultado quantitativo com a frequência das ideias centrais relativas à pergunta $\mathrm{n} \times 3$.

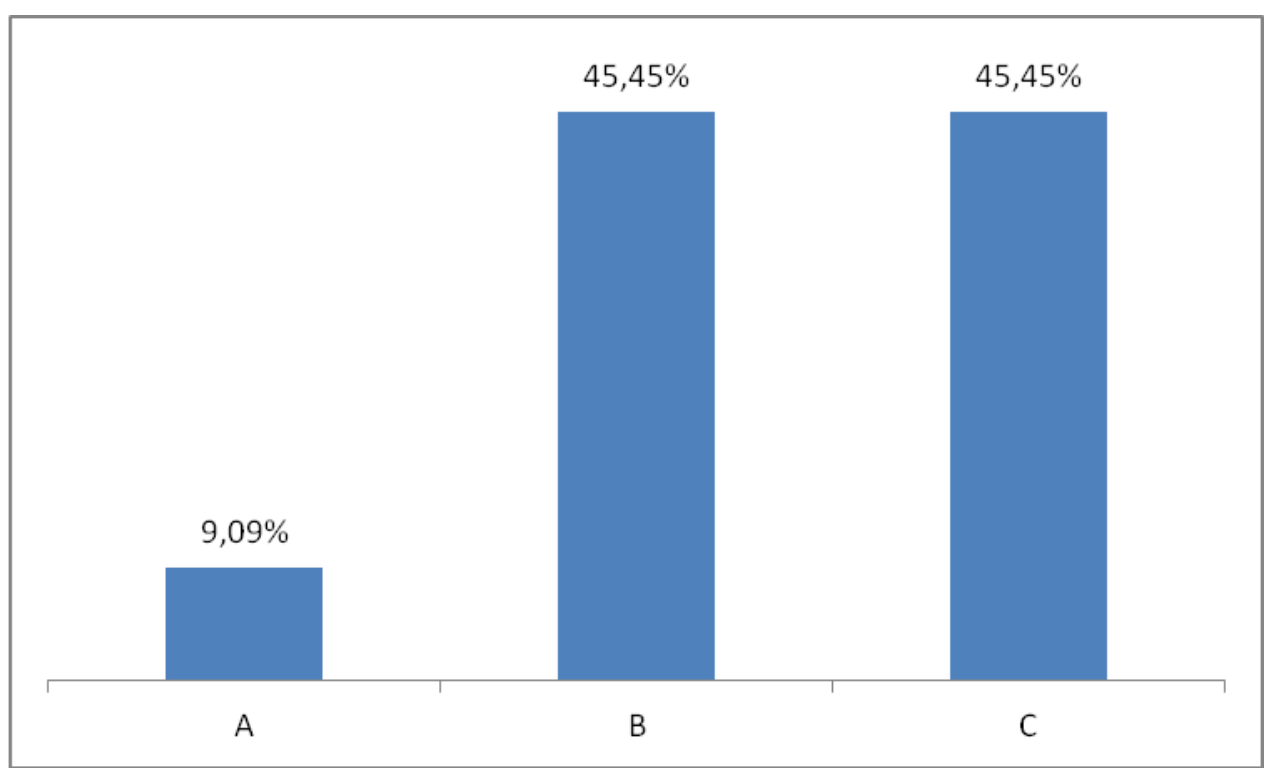

Figura 3 - Incidência das Ideias Centrais: pergunta no 3 
Ideia Central A (P03 - ICA): Sim. Ações judiciais de alimentos com premissas financeiras devem ser analisadas a partir da lógica da Assistência Social.

Discurso do Sujeito Coletivo:

Recorrer a um leite de cem reais pode ser mais fácil, mesmo sabendo que existem alternativas alimentares. Mas uma família que não pode comprar um leite $N A N^{\circledR}$ e um APTAMIL ${ }^{\circledR}$ é uma família pobre. Os pedidos solicitando fórmulas nutricionais apresentam perfil da assistência social.

Ideia Central B (P03 - ICA): Não. Guardam compatibilidade com medicamentos.

Discurso do Sujeito Coletivo:

Os casos de situações complexas de saúde, como, por exemplo, pessoas acamadas e com gastrostomias devem ser abordados de forma semelhante aos medicamentos. A análise é a mesma de ações que se pedem medicamentos. 0 Judiciário trata a mesma coisa, trata como o que busca o restabelecimento da saúde, pois inserem todas as demandas como direito à saúde, determinam o fornecimento pelo SUS.

Ideia Central C (P03 - ICA): Sim. Os critérios técnicos e científicos são diferentes.

Discurso do Sujeito Coletivo:

São políticas públicas diferentes, mas a política de Assistência Farmacêutica é mais complexa que a de alimentação. Além disso, os critérios técnicos e científicos serão diferenciados.

Nessa questão, o objetivo foi conhecer a percepção dos entrevistados sobre a análise técnica dos processos judiciais sobre fórmulas nutricionais e medicamentos, se há ou não diferença entre os dois.

Segundo a ANVISA:

Os alimentos para fins especiais são produtos especialmente formulados ou processados, nos quais se introduzem modificações no conteúdo de nutrientes, adequados à utilização em dietas, diferenciadas e ou opcionais, atendendo às necessidades de pessoas em condições metabólicas e fisiológicas específicas (BRASIL, 1998). 
Dentro desta classificação estão as fórmulas infantis para necessidades dietoterápicas especificas, fórmulas para nutrição enteral, alimentos para dietas com restrição de nutrientes (erros inatos do metabolismo) e alimentos para intolerância. Para o presente estudo foram consideradas fórmulas nutricionais todas as citadas acima.

Os resultados deste estudo permitem verificar que não há coerência quanto à análise técnica dos processos que solicitam medicamentos dos que solicitam fórmulas nutricionais, sendo que $45 \%$ dos discursos referem que a análise dos processos é a mesma que a de medicamentos e $45 \%$ disseram que não, são diferentes. Assim, observa-se que há um entendimento que fórmulas nutricionais ora são medicamentos, ora são alimentos.

Tais resultados só reforçam a tese de que o Poder Judiciário não está preparado para julgar ações em que o objeto material da demanda seja o direito à alimentação, tendo em vista as impropriedades no trato com a matéria (DELDUQUE e SILVA, 2014).

Obviamente, a análise técnica farmacêutica é diferente da nutricional. $\mathrm{Na}$ farmacêutica as atribuições do núcleo de conhecimento, como o uso racional dos medicamentos e os possíveis danos oriundos da má indicação e do mau uso são essenciais, além de questões relacionadas à Politica Nacional de Assistência Farmacêutica no âmbito do SUS (MESSEDER, 2005).

Borges e Ugá (2005) afirmam que, nas decisões para fornecimento de medicamentos, é necessária a utilização de critérios por parte do juiz, que, por não possuir expertise no tema, deve buscar, além dos fundamentos legais aplicáveis ao caso, a política e os programas de assistência farmacêutica.

Já na análise técnica das ações de fórmulas alimentares, devem ser avaliados os padrões nutricionais e dietéticos das fórmulas nutricionais, como quantidade e a qualidade dos macros e micronutrientes, densidade energética, relação das calorias não proteicas por grama de nitrogênio, osmolaridade/osmolalidade, presença ou não de fibras, além das necessidades nutricionais, avaliação clínica e nutricional e a adequação da prescrição 
dietoterápica ao quadro clínico do paciente (BRASIL, 2015b). Assim, o nutricionista, profissional habilitado para este fim, é imprescindível.

No entanto, Petean et al (2012) e Delduque e Silva (2014) verificaram que o profissional nutricionista é pouco citado nas demandas judiciais. São escassos os processos que mencionam esse profissional, quer prescrevendo a fórmula nutricional, quer funcionando como perito do juízo. Mais uma vez prevalece o receituário médico, reafirmando destaque central e hegemônico nas demandas judiciais.

Vale ressaltar que as fórmulas nutricionais não são classificadas como medicamentos e sim como alimentos pela ANVISA. Mas, verifica-se que, com a criação do Programa Nacional de Triagem Neonatal (PNTN) pelo Ministério da Saúde em 2001, foi incorporado o tratamento da Fenilcetonúria com a fórmula nutricional isenta de Phe (fenilalanina) na lista do Componente Especializado da Assistência Farmacêutica (CEAF), sendo totalmente financiado pelo SUS dentro dos critérios estabelecidos pelo Protocolo Clínico e Diretrizes Terapêuticas (PCDT) para Fenilcetonuria (TREVISAN, 2013). Essa incorporação da fórmula nutricional na Relação Nacional de Medicamentos (RENAME) ocasionou aos estados uma "obrigatoriedade" no fornecimento dessas fórmulas, seja por via judicial ou por organização de protocolos locais (FINK et al, 2010). Tal incorporação pode contribuir para o entendimento dessa classe de produtos alimentícios (alimentos para fins especiais) como medicamentos e não como alimentos.

A função das fórmulas nutricionais é nutrir o organismo e, em alguns casos, como a fenilcetonúria, complementar com nutrientes essenciais para a manutenção do organismo. Tais características também podem estar relacionadas à associação das fórmulas nutricionais com medicamento.

Observa-se que essa interpretação das fórmulas nutricionais, ora como medicamento, ora como alimento, também está presente no próprio no campo da alimentação e nutrição e nas práticas do profissional nutricionista, merecendo ser objeto de debates acerca de diferenças conceituais e ideológicas.

A P03- ICA indica que os processos para acesso às fórmulas nutricionais apresentam perfil da assistência social por apresentarem custo financeiro elevado. 
Observa-se que há uma análise diferenciada do Judiciário por apresentarem tal perfil. Além disso, nota-se uma conexão entre as políticas de SAN e assistencialismo alimentar.

Para Aranha (2005), o debate entre assistência e assistencialismo no campo da assistência social demonstra indícios de superação, principalmente depois da Lei Orgânica da Assistência Social (LOAS). Mas, no campo da SAN, a clareza da assistência alimentar enquanto direito e não como assistencialismo ainda persiste. Este equívoco deveria ter sido superado desde a Constituição Federal de 1988, que reconhece a assistência social como direito. Assim, o acesso ao alimento deve ser considerado um direito social e, portanto, garantido pelo Estado para as pessoas que se encontram em situações de vulnerabilidade, uma vez que tais situações também dizem o estado de insegurança alimentar e a nutrição dos indivíduos.

A alimentação como direito constitucional exige do Estado a revisão de suas ações relacionadas à SAN, das políticas de seguridade social e da forma como são desenvolvidas. A abordagem dos direitos humanos é incompatível com o paradigma do assistencialismo e do paternalismo, características historicamente frequentes em ações nessas áreas. A alimentação, como um direito constitucional, exige uma abordagem que reafirme o direito de cada pessoa de ser "titular" - e não "beneficiário" - de políticas públicas voltadas para o alcance da segurança alimentar e nutricional (LEÃO, 2013).

Nesse sentido, faz-se necessário o Sistema de Justiça debater o acesso às fórmulas nutricionais também no âmbito do Sistema Único de Assistência Social (SUAS) pois, no geral, a assistência social é tratada como política pública de Estado.

\section{Pergunta 04: 0 que o senhor(a) identifica como possíveis causas da judicialização para acesso às fórmulas nutricionais no SUS?}

Para essa questão, foram construídas oito categorias de acordo com as ideias centrais. Para cada ideia central foi construído um DSC. 
Quadro 4 - Ideias Centrais relacionadas à Pergunta nº 4

\begin{tabular}{|c|c|c|}
\hline P04-ICA & LOBBY DAS INDÚSTRIAS. & $19 \%$ \\
\hline P04-ICB & $\begin{array}{l}\text { MOROSIDADE NA INCORPORAÇÃO DE TECNOLOGIAS NO SUS E } \\
\text { AVANCOS TECNOLÓGICOS EM SAÚDE. }\end{array}$ & $14,2 \%$ \\
\hline P04-ICC & $\begin{array}{l}\text { INCOMPREENSÄO DO SISTEMA DE JUSTIÇA SOBRE O DIREITO À } \\
\text { ALIMENTACÃO }\end{array}$ & $4,7 \%$ \\
\hline P04-ICD & $\begin{array}{l}\text { DEFICIEENCIA DE POLITICAS PÚBLICAS PARA ACESSO ÀS } \\
\text { FÓRMULAS NUTRICIONAIS NO SUS }\end{array}$ & $19 \%$ \\
\hline P04-ICE & FALTA DE INFORMAÇÃO SOBRE O SUS. & $9,5 \%$ \\
\hline P04-ICF & BANALIZAÇÃO DO ACESSO AO JUDICIÁRIO & $19 \%$ \\
\hline P04-ICG & TENSÃO: PÚBLICO E PRIVADO & $9,5 \%$ \\
\hline $\mathrm{P04-ICH}$ & GESTORES E PROFISSIONAIS DE SAÚDE MAL QUALIFICADOS & $4,7 \%$ \\
\hline
\end{tabular}

Fonte: SILVA, 2016.

A figura 4 apresenta o resultado quantitativo com a frequência das ideias centrais relativas à pergunta $\mathrm{n} 04$.

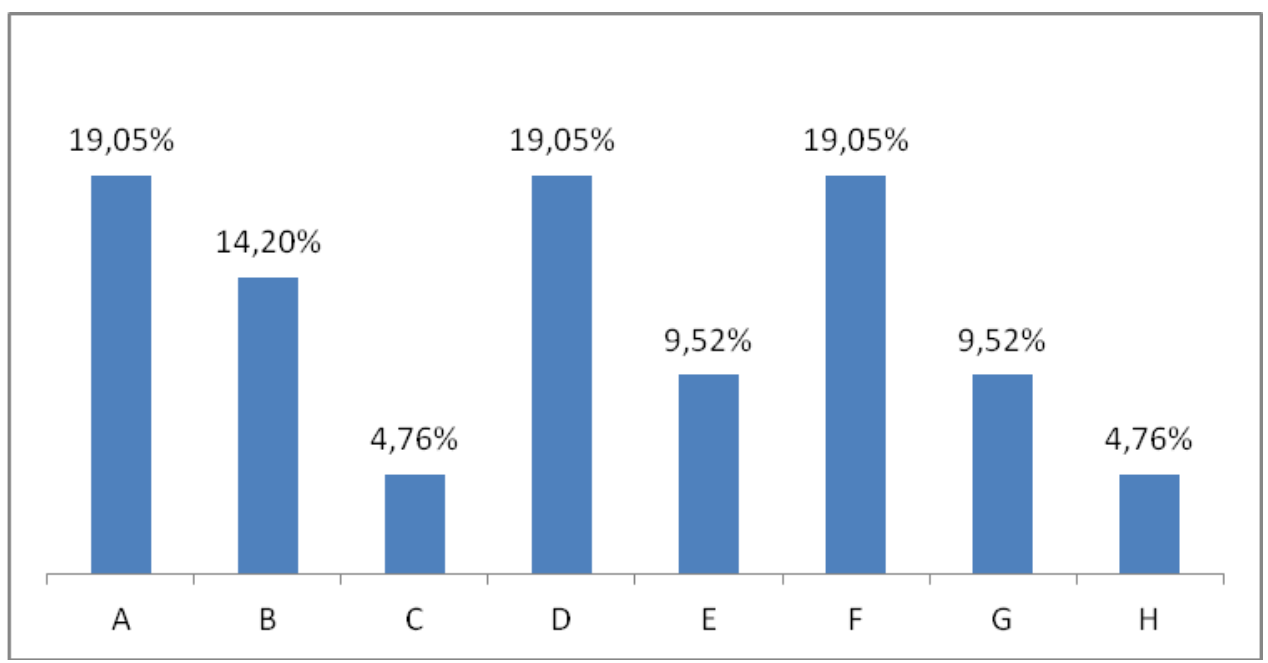

Figura 4 - Incidência das Ideias Centrais: pergunta nำ 4

\section{Ideia Central A (P04 - ICA): Lobby das indústrias.}

Discurso do Sujeito Coletivo:

A propaganda realizada pelos laboratórios junto aos médicos e os meios de comunicação, a publicidade e o poder de lobby dos mercados e laboratórios, fomenta a judicialização da saúde. É algo comum, os médicos e, talvez, os nutricionistas, serem influenciados direta ou indiretamente pelo lobby das indústrias. Os médicos indicam marcas e não princípio ativo. Pode ser um costume, mas é um costume ilegal. 
Ideia Central B (P04 - ICB): Morosidade na incorporação de tecnologias no SUS e avanços tecnológicos em saúde.

Discurso do Sujeito Coletivo:

A incorporação de novas tecnologias no âmbito do SUS é lenta, o que faz que, em alguns casos, o autor da ação tenha direito ao recebimento dessas fórmulas nutricionais via judicialização. Há o descompasso entre o que há no mercado e o que o SUS incorpora; quanto maior esse descompasso, maior é a judicialização. Vai ser diretamente proporcional, se o SUS incorpora muito pouco do que o mercado oferece, as pessoas irão demandar mais para ter acesso.

Ideia Central C (P04 - ICC): Incompreensão do Sistema de Justiça sobre o direito à alimentação.

Discurso do Sujeito Coletivo:

Se o direito à alimentação é um direito à saúde, porque a saúde tem os fatores determinantes da saúde e alimentação, então a alimentação é um fator determinante da saúde, está previsto na Constituição. Mas como lazer também é. E ninguém pensa em ir ao Ministério da Saúde pedir lazer, no entanto, pensam no Ministério da Saúde pedir alimentação. Talvez seja o caso de imaginar-se que as pessoas deveriam pedir alimentação no Ministério da Agricultura e não no MS.

Ideia Central D (P04 - ICD): Deficiência de políticas públicas para acesso às formulas nutricionais no SUS.

Discurso do Sujeito Coletivo:

O Estado tem o dever de fornecer alimentos que contribuíam na melhora da saúde dos indivíduos, mas verifica-se que há uma baixa constitucionalidade do direito à alimentação, pois não há políticas públicas que forneçam esses alimentos. $A$ baixa constitucionalidade é no sentido de que ele ainda não é aplicado de uma forma adequada, não se conferiu ainda ao direito à alimentação o patamar que a Constituição outorgou no plano fático. Há uma deficiência da execução das políticas públicas pelo Executivo, principalmente, nos municípios. Essa má gestão acarreta falta de insumos que são financiados pelo Ministério da Saúde. 
Ideia Central E (P04 - ICE): Falta de informação sobre o SUS.

Discurso do Sujeito Coletivo:

Informações equivocadas sobre SUS que é propagandeado diariamente nos meios de comunicação, do atraso no fornecimento de medicamentos, fórmulas nutricionais e tratamentos, além da má gestão do dinheiro público, fazem com que as decisões judiciais tenham um caráter de sermões do Judiciário no Poder Executivo.

Ideia Central F (P04 - ICF): Banalização do acesso ao Judiciário.

Discurso do Sujeito Coletivo:

Existem prescrições que não atendem às exigências médicas, verificam-se interesses de médicos em que o Estado forneça insumos e procedimentos que não estão na tabela do SUS. Há pacientes que não apresentam problemas de saúde ligados a ingestão de alimentos, mas como está alimentando pouco, o médico prescreve algum suplemento alimentar. Estamos estagnados nessa banalização do acesso ao Judiciário para demandas que muitas vezes o Estado fornece. Em diversos pleitos orienta-se as Procuradorias a pedirem falta de interesse em agir. As ações judiciais apresentam laudos, pareceres e publicações da internet, além do fornecimento de medicamentos que não apresentam eficácia comprovada. É uma estruturação que foi feita a fim de burlar o sistema.

\section{Ideia Central G (P04 - ICG): Tensão - público e privado.}

Discurso do Sujeito Coletivo:

As pessoas buscam exames e diagnósticos no setor privado, mas querem os produtos do SUS. Só que o SUS tem uma porta de entrada, uma organização da sua rede e, dependendo da situação, ele não fornece uma determinada marca e sim outra. Mas convencer os indivíduos a acessar a porta de entrada do SUS não é uma atitude fácil. Embora o correto seja isso, as pessoas se recusam. Essa tensão do público e privado gera muitas ações conta o SUS. 


\section{Ideia Central H (P04 - ICH): Gestores e profissionais de saúde pouco qualificados.}

Discurso do Sujeito Coletivo:

A má gestão, ausência de meritocracia, gestores adequados e qualificados, equipe de servidores que muitas vezes não têm qualificação é algo comum nos municípios no Brasil. Há uma tendência de omissão do ente público, da concretização de uma política nutricional adequada.

Nessa questão, o objetivo foi conhecer a percepção do Sistema de Justiça sobre as possíveis causas da judicialização do acesso às fórmulas nutricionais no SUS.

Interessante observar que as razões da judicialização do acesso às fórmulas nutricionais não são diferentes das causas da judicialização da saúde.

Identifica-se que as categorias $\mathrm{A}, \mathrm{D}$ e $\mathrm{H}(\mathrm{P} 04-\mathrm{ICA} / \mathrm{ICD} / \mathrm{ICH})$ foram mais frequentes, com a participação de $19 \%$ dos sujeitos, seguida pela categoria B com $14 \%$ dos sujeitos.

O lobby ${ }^{15}$ do mercado e da indústria é uma das razões mais relevantes para a judicialização da saúde (CAMPOS NETO et al, 2010; CHIEFFI e BARATA, 2010; SOARES e DEPRÁ, 2012) e também verificada na P04- ICA. Ademais, há um corpo de evidências que remete à existência de uma junção perversa de interesses entre o campo científico e prático da saúde e as indústrias farmacêutica, de tabaco, de álcool e de alimentos (GRÜNING, GILMORE e MCKEE, 2006; BROWNELL e WARNER, 2009; ROTHMAN, 2012; CANELLA et al, 2015).

Os fatores relacionados ao lobby da indústria farmacêutica não são diferentes da indústria de alimentos. Canella et al (2015) apontam a existência de conflitos de interesse nas parcerias da indústria de alimentos e bebidas com entidades científicas. Essas indústrias usam de estratégias para conquistar o apoio de consumidores e profissionais de saúde, bem como o governo, com investimentos em pesquisa, honorários, assessorias, doações ou mesmo pelo financiamento de eventos científicos (PEREIRA et al 2016, no prelo).

${ }^{15}$ Lobby (do inglês lobby, antessala, corredor) ou lobbying é o nome que se dá à atividade de pressão, ostensiva ou velada, de um grupo organizado com o objetivo de interferir diretamente nas decisões do poder público, em favor de causas ou objetivos defendidos pelo grupo. 
Ainda no campo da alimentação e nutrição, observa-se que as diversas causas do desmame precoce nas crianças menores de seis meses é influenciada pela presença e o marketing dos leites artificiais (leites infantis modificados ou fórmulas, leite integral, além de farinhas, potinhos e cereais infantis). E o maior investimento promocional da indústria está na visita dos serviços e profissionais de saúde, tornando-os vítimas e aliados das suas práticas promocionais (REA e TOMA, 2000).

Além disso, observa-se que há iniciativas internacionais que têm como foco a redução de carências nutricionais, como anemia, com foco na fortificação de alimentos, principalmente em países em desenvolvimento. Como exemplo, tem- se a iniciativa Scaling Up Nutrition (SUN), que se apresenta como um movimento global multisetorial que inclui governo, sociedade civil e setor empresarial, encorajando parcerias público-privadas com ênfase na fortificação de alimentos com micronutrientes. Para a International Baby Food Ection Network (IBFAN), essa iniciativa além de desestimular a amamentação e a cultura alimentar, gera uma dependência de produtos alimentícios importados inapropriados e de uma expertise estrangeira aos países em desenvolvimento (IBFAN, 2012).

Petean (2012) e colaboradores encontram prescrições com hegemonia de duas marcas, NESTLÉ ${ }^{\circledR}$ e ABBOTT $^{\circledR}$, impondo o uso dessas marcas comerciais em todas as decisões.

Observa-se que na literatura científica nacional não foram encontrados estudos que tratam de conflito de interesse no uso e recomendação de fórmulas nutricionais industrializadas, principalmente as fórmulas para uso enteral e fórmulas infantis.

No tocante à judicialização da saúde, observa-se que muitas liminares têm como objetivo atender a prescrições de produtos de alto custo e de determinada marca (CHIEFFI e BARATA, 2010). O lobby da indústria junto às associações, entidades de classe e profissionais da saúde faz com que os usuários e os prescritores passem a considerar imprescindível o uso de determinado medicamento, fórmulas nutricionais e outros insumos de saúde (ANGELL, 2007). Além disso, alguns estudos demonstraram a predominância de poucos advogados e 
prescritores envolvidos com muitas ações judiciais, o que pode sugerir a existência de conflito de interesses (MACHADO et al, 2011; PEREIRA et al, 2014).

O fornecimento de alimentos por entes públicos para a garantia do direito à alimentação foi muito marcante na P04 - ICD, revelando novamente uma percepção simplista do Sistema de Justiça quanto ao direito à alimentação. Buzanello (2009) aponta o direito à alimentação como uma área complexa do conhecimento jurídico e não tem a devida consideração por parte dos magistrados brasileiros. Há uma limitação desses magistrados sobre reconhecimento do direito à alimentação no campo do direito positivo, desrespeitando o direito à alimentação, previsto em lei.

A P04 - ICF revela que a maioria das demandas encaminhadas ao Judiciário poderiam ser trabalhadas administrativamente. Ademais, os laudos médicos inconsistentes, mas deferidos pelo Judiciário, e a comodidade do uso de certos insumos banalizaram a judicialização da saúde.

Segundo Pepe et al (2010) todos os processos ajuizados no estado do Rio de Janeiro no ano de 2006 obtiveram liminarmente seus pleitos e apenas três sentenças finais foram negadas.

A respeito do padrão de decisões judiciais, em estudo realizado por Ventura et al (2010), constatou-se que, em 96,9\% dos casos, não houve nenhuma exigência do juiz para a concessão ou manutenção do pedido liminar, demonstrando que a decisão baseia-se apenas na documentação apresentada pelo reivindicante, confirmando a soberania da prescrição médica, sem nenhuma contestação sobre a adequação do pleito às normas sanitárias, às possíveis alternativas terapêticas, real urgência no acesso ou sobre a incorporação para fornecimento pelo SUS.

Estudos demonstram que sentenças eram proferidas e cumpridas sem a correta avaliação do pleito, desconsiderando as consequências sobre a saúde do indivíduo, uma vez que indicações não adequadas também podem estabelecer algum agravo à saúde (MESSEDER; OSORIO-DE-CASTRO e LUIZA, 2005).

A morosidade na incorporação de novas tecnologias de saúde no SUS é expressa na P04 - ICB. A incorporação, exclusão e alteração de uso de tecnologias no SUS são de competência da Comissão Nacional de Incorporação de Tecnologias (CONITEC), órgão do Ministério da Saúde. Essa Comissão tem critérios bem 
definidos para incorporação de tecnologias, que perpassam pelos prazos para avaliação e oferta, transparência no processo de avaliação e participação popular por meio de consultas públicas, além de análise de registro, eficácia, segurança, efetividade e custo-efetividade (PETRAMALE, 2014, BRASIL, 2012c).

São esses os critérios que norteiam a decisão do SUS pela incorporação de fórmulas nutricionais, produto farmacêutico, procedimentos e outros insumos de saúde e é imprescindível que existam esses parâmetros, pois racionalizam o uso da terapêutica e os recursos públicos.

Macedo et al (2011) destacam que o limite da obrigatoriedade que norteia a incorporação de tecnologias no SUS colabora para a utilização da via judicial como mecanismo de acesso a tecnologias não padronizadas.

A P05- ICE demonstra que as informações sobre a má gestão do SUS propagandeadas na mídia contra o sistema também colaboram para a judicialização da saúde. Para Oliveira (2000), o sistema midiático reproduz formas de relações sociais e de poder e suas preocupações não estão direcionadas a mudanças nos cenários de poder ou nas condições de vida da população. A mídia é responsável pelo monopólio da fala e pela constituição da agenda pública e mostra-se mais preocupada em produzir notícias que revelam a má gestão do SUS do que as mudanças provocadas no cenário social. Verificam-se, rotineiramente, os escândalos e notícias de impacto, como a morte nas filas de atendimento, falta de medicamentos e insumos, a corrupção desenfreada e o mau atendimento, dentre outras situações.

A P04 - ICG evidencia que os indivíduos provocam o Judiciário para receber insumos e procedimentos prescritos pelo profissional do seu plano privado de saúde. Em muitos casos, são orientados a acessarem o SUS pela "porta de entrada", ou seja, as Unidades Básicas de Saúde (UBS), e seguirem o fluxo organizado do sistema. Mas verifica-se que muitos não aceitam e se recusam a seguir pela via "normal", assim, insistem em manter as ações judiciais em desfavor do sistema público de saúde.

Tal fato pode ser atribuído às barreiras de acesso ao atendimento no SUS. De acordo com o estudo de Carvalho e Gianini (2008) que discutiram as iniquidades de 
tempo de espera do usuário do SUS, a diferença chega a 5,5 meses em relação ao atendimento privado. Observaram que há uma pressão dos planos de saúde privados para que os usuários entrem com ações judiciais contra o SUS e, muitas vezes, negam o atendimento quando o cidadão mais precisa, não fornecem medicamentos, fórmulas nutricionais, exames, cirurgias e, frequentemente, dificultam o atendimento dos que mais necessitam de atenção médica, como os idosos, os pacientes crônicos e os indivíduos com alguma deficiência.

\section{Pergunta 5: 0 que o Poder Judiciário pode colaborar para resolução desses problemas?}

Para essa questão, foram construídas seis categorias de acordo com as ideias centrais. Para cada ideia central foi construído um DSC.

Quadro 5 - Ideias Centrais relacionadas à Pergunta ํo 5

\begin{tabular}{|llc|}
\hline P05-ICA & $\begin{array}{l}\text { INSTITUIR OS DIÁLOGOS INSTITUCIONAIS E COMPREENDER A } \\
\text { COMPLEXIDADE DO SUS }\end{array}$ & $54,5 \%$ \\
\hline P05-ICB & INSTITUCIONALIZAR OS COMITÊS DE MEDIAÇÃO SANITÁRIA & $18 \%$ \\
\hline P05-ICC & $\begin{array}{l}\text { O MINISTÉRIO PÚBLICO REALIZAR O CONTROLE DAS } \\
\text { POLIIICAS PÚBLICAS DE ALIMENTAÇÃO E NUTRIÇÃO }\end{array}$ & $9 \%$ \\
\hline P05-ICD & $\begin{array}{l}\text { RESPEITAR A AUTONOMIA DO PODER EXECUTIVO E ATUAR } \\
\text { NOS CASOS DE OMISSÃO E ERRO }\end{array}$ & $4,5 \%$ \\
\hline P05-ICE & TRABALHAR POSITIVAMENTE NA MÍDIA PELO SUS & $4,5 \%$ \\
\hline P05-ICF & $\begin{array}{l}\text { O SISTEMA DE JUSTIÇA ORGANIZAR AS DEMANDAS DOS } \\
\text { POBRES E EXCLUÍDOS COMO PRIORIDADE NO SISTEMA DE } \\
\text { SAÚDE }\end{array}$ & $9 \%$ \\
\hline
\end{tabular}

Fonte: SILVA, 2016.

A figura 5 apresenta 0 resultado quantitativo com a frequência das Ideias Centrais relativas à pergunta $\mathrm{n}^{\circ} 5$. 


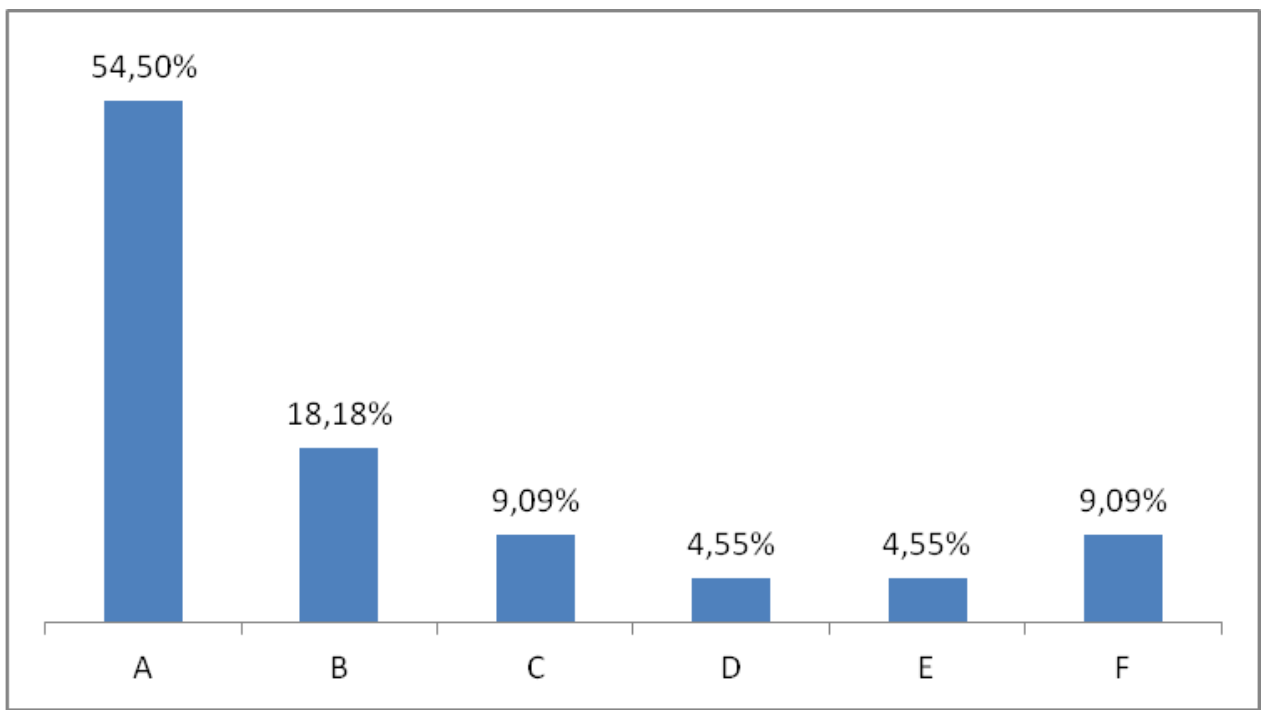

Figura 5 - Incidência das Ideias Centrais: pergunta no 5

\section{Ideia Central A (P05 - ICA): Instituir os diálogos institucionais e compreender a complexidade do SUS.}

Discurso do Sujeito Coletivo:

A partir de uma determinada fase do sistema social ou com o próprio advento da Constituição Federal, o sistema de saúde não pode andar dissociado do Sistema de Justiça. É necessário encontrar alternativas para aproximar os dois sistemas. E uma dessas são os diálogos institucionais, uma vez que o Sistema de Justiça não conhece de nutrição, de financiamento e execução do orçamento público e de doenças que têm origem de disfunções nutricionais, tampouco a complexidade do SUS.

Ideia Central B (P05 - ICB): Institucionalizar os Comitês de Mediação Sanitária.

Discurso do Sujeito Coletivo:

O Judiciário criou, por meio do CNJ, os comitês distritais de saúde, comitês estaduais de saúde que nós participamos e que têm reuniões periódicas, que visam à mediação e soluções de qualquer demanda de saúde. Os processos de mediação têm a possibilidade de diminuir a conflituosidade e litigiosidade. 
Ideia Central C (P05 - ICC): O Ministério Público realizar o controle das políticas públicas de alimentação e nutrição.

Discurso do Sujeito Coletivo:

Cabe ao Ministério Público realizar o controle prévio da atuação dos entes públicos e nesse caso, se há um déficit ou deficiência de política nutricional. O papel do Ministério Público é resolver essas questões por meio de termo de ajustamento de conduta junto aos entes federados. Já na esfera extrajudicial é que ele judicialize mediante ação coletiva.

\section{Ideia Central D (P05 - ICD):Respeitar a autonomia do Poder Executivo e atuar nos casos de omissão e erro.}

Discurso do Sujeito Coletivo:

A principal medida que deve ser adotada pelo Judiciário para diminuir a judicialização é respeitar a função privativa da administração pública e atuar somente nos casos de erro e omissão devidamente comprovados.

Ideia Central E (P05 - ICE): Trabalhar positivamente na mídia pelo SUS.

Discurso do Sujeito Coletivo:

Não há um esforço do Ministério da Saúde em trabalhar positivamente pelo SUS na mídia. A imprensa só mostra o que há de errado no sistema.

Ideia Central F (P05 - ICF): O Sistema de Justiça deve organizar as demandas dos pobres e excluídos como prioridade no sistema de saúde.

Discurso do Sujeito Coletivo:

A judicialização serve, em vários casos, como a voz dos excluídos e dos pobres que não conseguem se organizar. No entanto, referir a judicialização como um movimento de elite que quer cada vez mais privilégios em cima do sistema público de saúde que é combalido, não é o certo.

Nessa questão, o objetivo foi conhecer a percepção do Sistema de Justiça sobre o seu papel na resolução dos problemas relacionados à pergunta $\mathrm{n}^{0} 4$.

Para o Sistema de Justiça, os diálogos institucionais são a estratégia necessária para o enfrentamento da judicialização da saúde (P05 - ICA). Nota-se 
que há um diálogo superficial entre o Sistema de Justiça e o sistema de saúde, verificado na violação dos limites de atuação de cada sistema. Assim, espaços institucionais pactuados entre a justiça e a saúde são necessários. Asensi e Pinheiro (2015) demonstraram que um cotidiano colaborativo e compartilhado entre atores políticos e jurídicos contribui para efetivação do direito à saúde.

Assis (2015) relata que esses espaços devem assegurar aos diversos órgãos, como o Ministério Público, Defensoria e os magistrados, a compreensão das suas funções no resultado sanitário, dentro de um ambiente de interação institucional democrático.

Verifica-se que a comunicação real entre os sistemas de justiça e da saúde auxilia na defesa técnica judicial do gestor que deve oferecer subsídios técnicos que demonstram a inadequação do medicamento pleiteado ou fórmulas nutricionais, bem como as alternativas mais seguras disponíveis no SUS. Desse modo, é necessário impulsionar a criação desses espaços de diálogo e a formação de políticas públicas eficientes (PEPE, et al., 2010; SANT'ANA et al., 2011).

Além disso, verifica-se que o Sistema de Justiça deve ser inserido na discussão da Segurança Alimentar e Nutricional e do Direito Humano à Alimentação Adequada (DHAA), tanto por meio do Conselho Nacional de Segurança Alimentar e Nutricional (CONSEA) e das CAISAN federal, estaduais e municipais quanto das Conferências de Segurança Alimentar e Nutricional, de forma a discutir o real papel do SUS na garantia desses produtos alimentícios com características terapêuticas.

Compreender a complexidade do SUS também foi um aspecto relevante nessa categoria. Marques (2011) destaca que, como as decisões judiciais sobre direito à saúde são analisadas ao paradigma positivista, impede que a complexidade das questões técnicas e políticas no âmbito do SUS seja analisada.

A instituição de Comitês de Mediação Sanitária como forma de diminuir a conflituosidade e litigiosidade foi proposta por $18 \%$ dos entrevistados. Para Assis (2015), no campo dos direitos sociais é necessário repensar a atuação judicial, pois os instrumentos e ferramentas tradicionais utilizadas, como a atuação administrativa e o Termo de Ajustamento de Conduta (TAC), são ultrapassados. 
Assim, uma nova postura institucional que seja transversal e com participação direta na construção social e no direito à saúde é crucial. A mediação trabalha nessa perspectiva por produzir diálogos entre os sistemas de saúde e de justiça (ASSIS, 2015).

Para Delduque e Castro (2015), a mediação propõe controlar a abertura de processos judiciais de caráter litigioso e pôr fim àqueles iniciados, por se tratar de método pacífico de gestão de conflitos. Para esses autores, há três formas de resolver os conflitos: a) as resoluções estatais, ou seja, as decisões judiciais; b) as resoluções estatais negociadas com as partes por meio do Ministério Público, a Defensoria Pública e a Advocacia Geral da União; e c) a resolução dos conflitos pela via extrajudiciais, privados ou não. Eles defendem que a construção de núcleos de mediação sanitária, no âmbito das secretarias de saúde, contribui para a diminuição dos conflitos e da judicialização.

A P05 - ICC questiona o papel do Ministério Público no controle das políticas públicas de alimentação e nutrição para assegurar a atuação dos entes públicos na garantia do direito à alimentação. Verificam-se poucas ações coletivas envolvendo o direito à alimentação. As ações são majoritariamente propostas individualmente.

Medeiros, Diniz e Schwartz (2013) classificam esses casos com compensação, pois buscam ser compensados ou reparados de políticas omissas que não incluem os insumos nutricionais necessários a casos especiais, por outro lado, a realidade é que a efetivação desse direito pode comprometer o direito da coletividade.

Oliveira, Andrade e Milagres (2015) chamam atenção aos desafios impostos ao seu sistema para tratar as complexas questões sociais e a variedade de instrumentos assegurados à instituição para atingir suas finalidades institucionais. Assim, o Ministério Público deve criar estratégias alternativas e de procedimentos que levem à potencialização de seus resultados na busca pela efetividade dos direitos sociais.

Ademais, entre as instituições atualmente existentes no Brasil, com diferentes graus de autonomia e independência para receber, documentar e encaminhar denúncias de violações aos direitos humanos destacam-se o Ministério Público 
(MP), a Defensoria Pública, os Conselhos de Direitos Humanos e os Conselhos de Políticas Públicas. Na realidade, não se pode falar em direitos humanos sem falar em exigibilidade:

A exigibilidade (...) é, hoje, um imperativo na teoria e na prática dos direitos humanos. Afinal, as declarações de direitos, as constituições e as leis de um modo geral deixam de possuir qualquer significação prática se não tiverem a possibilidade de efetiva aplicação (BENVENUTO, 2005, p. 3).

Na prática, a exigibilidade ainda é associada à ideia de judiciabilidade (alguns usam também o termo justiciabilidade), isto é, a possibilidade de exigir direitos perante o Poder Judiciário. No entanto, a exigibilidade significa muito mais do que cobrar a realização de direitos perante os Tribunais de Justiça. A promoção da Justiça, em seu sentido mais amplo, não se constitui em obrigação apenas do Poder Judiciário, pelo contrário, é obrigação do Estado, sobretudo do Poder Executivo, por meio da implementação de políticas e programas públicos além de prestação de serviços públicos (LEÃO, 2013).

Além disso, e conforme dito anteriormente, no âmbito do SUS, verifica-se que há apenas um Protocolo Clínico e Diretrizes Terapêuticas (PCDT) que dispõe sobre os critérios clínicos e o fornecimento de fórmula nutricional isenta de fenilalanina (Phe) para indivíduos com fenilcetonúria (PKU do inglês PhenylKetonUria) (BRASIL, 2013b). Contudo, alguns estados e municípios possuem a rede de saúde organizada para o acompanhamento de indivíduos com necessidades alimentares especiais, contando com protocolos clínicos e/ou diretrizes terapêuticas próprios que contemplam o fornecimento de fórmulas nutricionais industrializadas financiadas pelos gestores locais (PEREIRA et al, 2014).

Na P05 - ICF há uma compreensão de que o Sistema de Justiça deve organizar as demandas dos pobres e excluídos como prioridade. Para Oliveira, Andrade e Milagres (2015), a judicialização é a forma encontrada por grupos marginalizados das arenas de discussão das políticas públicas para levar aos gestores as suas necessidades. As decisões judiciais levam à criação e à organização de políticas públicas para o atendimento de grupos minoritários, como portadores das chamadas "doenças órfãs".

Por outro lado, verifica-se que os mais beneficiados são aqueles já socialmente favorecidos, o que agrava as injustiças sociais no tocante ao acesso a 
bens e serviços de saúde. Os indivíduos em condições socioeconômicas favoráveis são os que têm acesso ao Judiciário e, por isso, as decisões judiciais Ihes concedem bens e serviços públicos de saúde questionando a judicialização da saúde como um mecanismo de injustiça distributiva (WANG, 2009).

Para Wang (2009), as demandas dos menos favorecidos são acolhidas no Ministério Público e na Defensoria Pública. Pode-se dizer que a judicialização da saúde, em alguma medida, promove a participação de uma parcela (pequena, se pensarmos nos problemas de acesso à justiça e na quantidade de falhas nos serviços de saúde) dos menos favorecidos nas políticas públicas de saúde. 


\section{CONSIDERAÇÕES FINAIS}

Este estudo objetivou conhecer e analisar as percepções do Sistema de Justiça sobre a judicialização do acesso às formulas nutricionais (alimentos) no âmbito do Sistema Único de Saúde.

Foi possível perceber que, a partir da análise das informações construídas, o Sistema de Justiça reconhece o direito à alimentação na Constituição Federal, mas evidencia que a sua efetivação é realizada por meio de políticas públicas que garantem alimentos, demonstrando uma consciência reduzida sobre as políticas de alimentação e nutrição.

Há um entendimento que a SAN não é aplicada nos processos judiciais em que há solicitação de fórmulas nutricionais. A compreensão que o direito à alimentação deve ser executado de forma diferente no campo da SAN e na saúde evidencia as dificuldades do Sistema de Justiça quanto ao direito à alimentação.

Os resultados deste estudo permitem verificar que não há coerência quanto à análise técnica dos processos que solicitam medicamentos dos que solicitam fórmulas nutricionais. Tais resultados só reforçam a tese que o Poder Judiciário não está preparado para julgar ações em que o objeto material da demanda seja o direito à alimentação, tendo em vista as impropriedades no trato com a matéria.

A interpretação das fórmulas nutricionais, ora como medicamento, ora como alimento, também está presente no próprio campo da alimentação e nutrição e nas práticas do profissional nutricionista, merecendo ser objeto de debates sobre as diferenças conceituais e ideológicas.

Para o Sistema de Justiça, o lobby do mercado e da indústria é a razão mais relevante para a judicialização da saúde. Mas, constata-se que não foram propostas ações para minimizar os impactos do lobby na judicialização da saúde. Portanto, cabe ao Estado e aos setores da sociedade pautados por interesses públicos promoverem a "desnaturalização" dessa praxe, como a regulação de produtos e práticas comerciais que comprometam a saúde pública. 
No Brasil, as políticas de Segurança Alimentar e Nutricional evoluíram consideravelmente nos últimos 10 anos. Mas, nota-se que o Sistema de Justiça mesmo sendo um sistema dinâmico, não acompanhou esta evolução.

Para o Sistema de Justiça, os diálogos institucionais são a estratégia precisa para o enfrentamento da judicialização da saúde. É necessário que esse Sistema seja inserido na discussão da Segurança Alimentar e Nutricional e do Direito Humano à Alimentação Adequada, seja por meio do CONSEA e das CAISAN federal, estaduais e municipais ou das Conferências de Segurança Alimentar e Nutricional, objetivando discutir o real papel do SUS na garantia desses produtos alimentícios com características terapêuticas.

Assim, é necessário que o Ministério da Saúde discuta junto à ANVISA, e outros setores, o papel terapêutico das fórmulas nutricionais a fim de aparar as arestas do que é medicamento e do que é alimento, bem como discutir com instâncias intersetoriais sobre até onde o SUS deve ser o responsável em garantir esses alimentos/produtos alimentícios com finalidade terapêutica.

O Poder Executivo mobiliza recursos humanos para responder tecnicamente ao Poder Judiciário as questões de saúde nos processos judiciais, mas percebe-se que, mesmo com o parecer técnico do Executivo, o Judiciário adota decisões contrárias. E com esse comportamento, cumpre-se a desestruturação das políticas públicas e do planejamento financeiro para a sua execução. Portanto, enquanto o Poder Judiciário imiscuir-se nas políticas públicas, não conseguirá minimizar os efeitos da judicialização das políticas de saúde e alimentação. 


\section{REFERÊNCIAS}

AITH, F. Curso de Direito Sanitário: a proteção do Direito à Saúde no Brasil. São Paulo: Quartier Latin, 2007.

ALVES, K.P. S.; JAIME, P. C. A Política Nacional de Alimentação e Nutrição e seu diálogo com a Política Nacional de Segurança Alimentar e Nutricional. Ciência \& Saúde Coletiva, 19 (11): 4331-4340, 2014.

AMARAL JUNIOR, J. L. M. do. Estado de direito e Ativismo Judicial. São Paulo: Quartier Latin, 2010.

ANGELL, M. A verdade sobre os laboratórios farmacêuticos: como somos enganados e o que podemos fazer a respeito. Rio de Janeiro: Record, 2007.

ARANHA, M. S. F. Projeto Escola Viva: garantindo o acesso e permanência de todos os alunos na escola: necessidades educacionais especiais dos alunos. Brasília: Ministério da Educação, Secretaria de Educação Especial, 2005.

ARAÚJO L. A. D.; NUNES JÚNIOR, V. D. Curso de Direito Constitucional. Imprenta: São Paulo, Saraiva, 2001. 448p.

ARAUJO, L. A. D.; SERRANO, V. Curso de Direito Constitucional. $12^{a}$ edição (atualizada até a Emenda Constitucional n. 56, de 20.12.2007). São Paulo: Saraiva, 2008.

ARENHART, S. C. As ações coletivas e o controle das políticas públicas pelo poder judiciário. Revista Eletrônica do Ministério Público Federal. Ano I, Número 1, 2009, 20p.

ASENSI, F.; PINHEIRO, R. Defensoria Pública e diálogo institucional em saúde: a experiência de Brasilia-DF. Revista Direito e Práxis. Rio de Janeiro, Vol. 06, N. 12, 2015, p. 11-36.

ASSIS, G. de. Mediação Sanitária: Direito, Saúde e Cidadania. In: CONASS. Direito à Saúde. Coleção Para Entender a Gestão do SUS, 2015.

BANDERA, A. Tratado de los estados de vida cristiana: introducción a las cuestiones. In: AQUINO, S. T. de. Suma de Teología IV: Edição dirigida por los Regentes de Estudios de las Provincias Dominicanas en España. Madrid: Biblioteca de Autores Cristianos, 1993. p. 638.

BAPTISTA, T. W. F.; MACHADO, C. V.; LIMA, L. D. de. Responsabilidade do Estado e direito à saúde no Brasil: um balanço da atuação dos Poderes. Ciência \& Saúde Coletiva, 14 (3): 829-839, 2009.

BARATA, R. B. Epidemiologia Social. Revista Brasileira de Epidemiologia, v.8, n.1, São Paulo, mar. 2005, p.7-17.

BARBOSA, M. C. Revisão da Teoria da Separação dos Poderes do Estado. Rev. Cient. Fac. Lour. Filho - v.5, n.1, 2006. 
BARROS, J. A. C.; JOANY, S. Anúncios em medicamentos em revistas medicas: ajudando a promover a boa prescrição? Ciência e Saúde Coletiva, 7(4):891-898; 2002.

BARROS, J. A. C. Politicas Farmacêuticas: A serviço dos interesses da saúde? Brasilia, UNESCO, 2004.

BARROSO, L. R. Curso de Direito Constitucional Contemporâneo: os conceitos fundamentais e a construção do novo modelo. 3. ed. São Paulo: Saraiva, 2011. $505 p$.

BASTOS, C. R. Curso de direito constitucional. São Paulo: Celso Bastos Editor, 2002.

BENVENUTO, J. O caráter expansivo dos Direitos Humanos na afirmação de sua indivisibilidade e exigibilidade. In: Revista Autor, 2005. Disponível em: $<\mathrm{http}$ ://www.revistaautor.com/index2.php?option=com_content\&do_pdf=1\&id=104>. Acesso em março de 2016.

BERTOLLI FILHO, C. História da Saúde Pública no Brasil. São Paulo: Ática, 2001. p. 34.

BEURLEN, A. Direito Humano à alimentação adequada no Brasil. Curitiba: Juruá Editora, 2008.

BOBBIO, N. A Era dos Direitos. Tradução: COUTINHO, C.N. Nova ed. Rio de Janeiro: Elsevier, 2004. 7ª reimpressão.

BONAVIDES, P. Curso de Direito Constitucional. 19å Edição, São Paulo: Editora Malheiros, 2006.

BORGES, D.C. L, UGÁ, M.A.D..Conflitos e impasses da judicialização na obtenção de medicamentos: as decisões de 1a instância nas ações individuais contra o Estado do Rio de Janeiro, Brasil, em 2005. Cad. Saúde Pública, Rio de Janeiro, 26(1):59-69, jan, 2010.

BRASIL. Constituição da Republica Federativa do Brasil. Brasília, DF: Senado Federal, 5 de outubro de 1988.

BRASIL. Decreto no 591, de 6 de julho de 1992. Atos Internacionais. Pacto Internacional sobre Direitos Econômicos, Sociais e Culturais. Diário Oficial da União, no 128, Seção 1, p. 8713-8716, 7 de julho de 1992.

BRASIL. Portaria no 29, de 13 de janeiro de 1998 (Versão Republicada 30/03/1998). Regulamento Técnico referente a Alimentos para Fins Especiais. Diário Oficial da União, Brasília, DF, 30 março de 1998.

BRASIL. Ministério da Saúde. Estudo Comparados: Regulamentação da Propaganda de Medicamentos. Série E. Legistação da Saúde. Brasilia: Ministerio da Saúde, 2005. 
BRASIL. Lei no 11.346 de 15 de setembro de 2006. Cria o Sistema Nacional de Segurança Alimentar e Nutricional - SISAN com vistas em assegurar o direito humano à alimentação adequada e dá outras providências. Diário Oficial da União, no 179, Seção 1, p. 1-2, 18 de setembro de 2006.

BRASIL. Conselho Nacional de Secretários de Saúde. Legislação Estruturante do SUS. Brasilia: CONASS, 2007. (Coleção Progestores-Para entender a gestão do SUS, 12).

BRASIL. Ministério da Saude. Secretaria de Gestão Estratégica e Participativa. Departamento de Apoio à Gestão Participativa. Caminhos do Direito à Saúde no Brasil. Brasilia. Ministério da Saúde, 2007b. (Série B. Textos Básicos de Saúde).

BRASIL. Ministério da Saúde. Secretaria de Atenção a Saúde. Portaria nº 120, de 14 de abril de 2009. Estabelece Normas de Classificação e Credenciamento/ Habilitação dos Serviços de Assistência de Alta Complexidade em Terapia Nutricional Enteral e Enteral/ Parenteral e dá outras providências. Diário Oficial da União, no 74, Seção 1, p. 72, 20 abril de 2009.

BRASIL. Constituição (1988). Emenda Constitucional no 64, de 4 de fevereiro de 2010. Altera 0 art. 6ำ da Constituição Federal para introduzir a alimentação como direito social. Diário Oficial da União, no 25, Seção 1, p. 1-2, 5 de fevereiro de 2010.

BRASIL. Decreto no 7.272 de 25 de agosto de 2010. Regulamenta a Lei no 11.346, de 15 de setembro de 2006, que cria o Sistema Nacional de Segurança Alimentar e Nutricional - SISAN com vistas a assegurar o direito humano à alimentação adequada, institui a Política Nacional de Segurança Alimentar e Nutricional PNSAN, estabelece os parâmetros para a elaboração do Plano Nacional de Segurança Alimentar e Nutricional, e dá outras providências. Diário Oficial da União, no 164, Seção 1, p. 6-8, 26 de agosto de 2010. 2010b.

BRASIL. Agência Nacional de Vigilância Sanitária (ANVISA). Resolução da Diretoria Colegiada no 45, de 19 de setembro de 2011. Dispõe sobre o regulamento técnico para fórmulas infantis para lactentes destinadas a necessidades dietoterápicas específicas e fórmulas infantis de seguimento para lactentes e crianças de primeira infância destinadas a necessidades dietoterápicas específicas. Diário Oficial da União nํ182, seção 1, p. 94-95, 21 de setembro de 2011.

BRASIL. Ministério da Saúde. Portaria no 533, de 28 de março de 2012. Estabelece o elenco de medicamentos e insumos da Relação Nacional de Medicamentos Essenciais (RENAME) no âmbito do Sistema Único de Saúde (SUS). Diário Oficial da União, nº 62, Seção 1, p. 96. 2012. 29 de março de 2012.

BRASIL. Ministério da Saúde. Secretaria de Atenção à Saúde. Departamento de Atenção Básica. Política Nacional de Alimentação e Nutrição. Brasília: Ministério da Saúde, 2012b. 84 p.: il. - (Série B. Textos Básicos de Saúde).

BRASIL. Ministério da Saúde. Portaria no 2.009, de 13 de setembro de 2012. Aprova o Regimento Interno da Comissão Nacional de Incorporação de Tecnologias no 
Sistema Único de Saúde (CONITEC). Diário Oficial da União, Seção 1, p. 65.14 de setembro de 2012c.

BRASIL. Ministério da Saúde. Portaria no 1307, de 22 de novembro de 2013. Aprova o Protocolo Clínico e Diretrizes Terapêuticas da Fenilcetonúria. Diário Oficial da União, 25 de novembro de 2013.

BRASIL. Conselho Nacional de Justiça. Censo do Poder Judiciário: VIDE: vetores iniciais e dados estatísticos. Brasília - CNJ, 2014. 212p.

BRASIL. Agência Nacional de Vigilância Sanitária (ANVISA). Resolução da Diretoria Colegiada no. 21, de 13 de maio de 2015. Dispõe sobre o regulamento técnico de fórmulas para nutrição enteral. Diário Oficial da União no 91, seção 1, p. 28 a 31 , 15 de maio de 2015.

BRASIL. Ministerio da Saude. Secretaria de Atenção à Saúde. Departamento de Atencao Basica. Cuidados em terapia nutricional / Ministerio da Saude, Secretaria de Atencao a Saude, Departamento de Atencao Basica. - 1. ed., 1. reimpressão. Brasilia: Ministerio da Saude, 2015b.3 v.: il. (Caderno de Atencao Domiciliar; v. 3).

BROWNELL, K. D.; WARNER, K. E. The perils of ignoring history: big tobacco played dirty and milliond died. How similar is big food? The Milbank Quarterly. 2009; 87(1): 259-94.

BUCCI, M. P. D. Direito administrativo e políticas públicas. São Paulo: Saraiva; 2002.

BURITY, V.; FRANCESCHINI, T.; RECINE, F. V. E.; LEÃO, M.; CARVALHO, M. F. Direito humano à alimentação adequada no contexto da segurança alimentar $e$ nutricional.Brasília, DF: ABRANDH, 2010. 204p.

BUZANELLO, J. C. Fundamentos Jurídicos do Direito à Alimentação. In: Anais do XVIII Congresso Nacional do CONPEDI, São Paulo, 2009.

CAMPOS NETO, O. H.; ACURCIO, F. A.; MACHADO, M. A. A.; FERRÁ, F.; BARBOSA, F. L. V.; CHERCHIGLIA, M. L., et al. Médicos, advogados e indústria farmacêutica na judicialização da saúde em Minas Gerais, Brasil. Rev. Saúde Pública, 2012; 46: 784-90.

CANELLA, D.S.; MARTINS, A.P.B.; SILVA, H.F.R.; PASSANHA, A.; LOURENÇO, B.H. Food and beverage industries participation in health scientific events: considerations on conflicts of interest. Revista Panamericana de Salud Publica (Print), v. 38, p. 339-343, 2015.

CARVALHO, T. C.; GIANINI, R.J..Equidade no tempo de espera para determinadas cirurgias eletivas segundo o tipo de hospital em Sorocaba, SP. Rev. Bras. Epidemiol. 2008; 11(3): 473-83.

CARVALHO, O. F. de. O direito fundamental à alimentação e sua proteção jurídicointernacional. Revista de Direito Público, Londrina, v. 7, n. 2, p. 181-224, maio/ago. 2012. 
CASTILHO, E. W. V.; SADEK, M. T. O Ministério Público Federal e a Administração da Justiça no Brasil [online]. Rio de Janeiro: Centro Edelstein de Pesquisa Social, 2010, 40p.

CHIEFFI, A. L.; BARATA, R. B. Ações judiciais: estratégia da indústria farmacêutica para introdução de novos medicamentos. Revista de Saúde Pública, v. 44, n. 3, p. 421-9, 2010.

COELHO, L. F. A Fundamentação do Direitos Humanos. In: KLOCK, A.B.; CAMBI, E.; ALVES, F.B. (Orgs). Direitos Fundamentais revisitados. Curitiba: Juruá editora, 2008. p. 39-88.

COMPARATO, F. K. A afirmação historica dos direitos humanos. 7. Ed. São Paulo: Saraiva, 2010.

CONSELHO NACIONAL DE SEGURANÇA ALIMENTAR E NUTRICIONAL (CONSEA). A Segurança Alimentar e Nutricional e $\mathbf{o}$ Direito Humano à Alimentação Adequada no Brasil Realização - Indicadores e Monitoramento - da Constituição de 1988 aos dias atuais. 2010. 284p.

CONSELHO NACIONAL DE SECRETÁRIOS MUNICIPAIS DE SAÚDE (CONASEMS). Carta de Brasília: XXIX Congresso Nacional de Secretarias Municipais de Saúde. Brasília, DF: 2013.

COSTA, F. C. A. Análise da implementação do projeto de Gestão da Informação e da Comunicação em Ciência e Tecnologia em Saúde - LOGICOS para a tomada de decisão dos gestores do Sistema Único de Saúde. 2013. 100f. [Dissertação]. Faculdade de Ciências da Saúde da Universidade de Brasília, Brasília, 2013.

COUTINHO, C.N. Notas sobre cidadania e modernidade In: Revista Praia Vermelha: estudos de política e teoria social, Vol. 1. Rio de Janeiro, UFRJ-DP\&A, 1997.

DALLARI, D. A. Elementos de Teoria Geral do Estado. 16. ed. São Paulo: Saraiva, 1991.

DALLARI, D. A. Elementos de Teoria Geral do Estado. Saraiva: São Paulo, 2006.

DALLARI, S. G. O Direito à Saúde. Revista de Saúde Pública, São Paulo 22 (1):5763, 1988.

DELDUQUE, M. C.; OLIVEIRA, M. S. C. O papel do Ministério Público no campo do Direito e Saúde. In: BRASIL. Ministério da Saúde. Fundação Osvaldo Cruz. Questões atuais do direito sanitário, 2006. (Serie Legislação de Saúde).

DELDUQUE, M. C.; MARQUES, S. B. A Judicialização da política de assistência farmacêutica no Distrito Federal: diálogos entre a política e o direito. Tempus Actas de Saúde Coletiva. v. 5, n. 4. 2011. 
DELDUQUE, M. C.; SILVA, A. B. da. O direito fundamental à alimentação nos tribunais: uma análise. Demetra. 2014; 9 (Supl.1); 393-408.

DELDUQUE, M. C.; CASTRO, E. V. de. A Mediação Sanitária como alternativa viável à judicialização das políticas de saúde no Brasil. Saúde Debate. Rio de Janeiro, v. 39, n. 105, p.506-513, abr-jun. 2015.

DIMOULIS, D.; LUNARDI, S. Curso de Processo Constitucional: controle de constitucionalidade e remédios constitucionais. São Paulo: Atlas, 2011. p. 9.

ESTORNINHO, M. J. (coord.). Estudos de Direito da Alimentação. Instituto de Ciências Jurídico-Políticas. Universidade de Lisboa. Faculdade de Direito. 2013.

FARIA, J. E. O Judiciário e os direitos humanos e sociais: nota para uma avaliação da justiça brasileira. In: FARIA, J. E. (org.) Direito e Justiça: Direitos humanos, direitos sociais e justiça. 3aㅡ tiragem: Malheiros, 2002.

FERRAZ, M. A. Direito à Alimentação e sustentabilidade. 2013. 189f. Faculdade de Direito da Universidade de São Paulo. [Dissertação]. São Paulo, 2013.

FERREIRA FILHO, M. G. Direitos Humanos Fundamentais. $11^{a}$ ed. São Paulo: Saraiva, 2009.

FERREIRA, R. S. Elaboração de fórmulas enterais artesanais de baixo custo adequadas em fluidez e osmolalidade. 2009. 98f. [Dissertação]. Universidade Federal de Viçosa, Minas Gerais, 2009.

FINK, J. S.; MELLO, E. D.; PICON, P. D. Impactos da implementação de um centro de referência em fórmulas nutricionais especiais. Revista da AMRIGS, Porto Alegre, 54 (2): 133-140, jan.-mar. 2010.

FLEURY, S.; FARIA, M. A judicialização como ameaça e salvaguarda do SUS. In: SANTOS, L.; TERRAZAS, F. (Org.). Judicialização da Saúde no SUS. 1ed.Rio de Janeiro: Saberes, 2014, v. 1, p. 99-123.

FOUCOULT, M. Microfísica do Poder. Rio de Janeiro: Graal, 1979.

FREYRE, G. Vida, forma e cor. Rio de Janeiro: Record, 1977.

GIL, A. C. Métodos e técnicas e pesquisa social. In: SIMIONI, A.M.C.; LEFÈVRE, F.; BICUDO PEREIRA, I.M.T. Metodologia qualitative nas pesquisas em saúde coletiva: considerações técnicas e instrumentais. São Paulo: FSP/USP, 1996. (Série Monográfica do Departamento de Prática de Saúde Pública da FSP, 2).

GOMES, S. A. Hermenêutica Constitucional: um contributo à construção do estado democrático de direito. Curitiba: Juruá, 2008.

GOMES, V. S.; AMADOR, T. A. Estudos publicados em periódicos indexados sobre decisões judiciais para acesso a medicamentos no Brasil: uma revisão sistemática. Cad. Saúde Pública, Rio de Janeiro, 31(3):451-462, mar, 2015. 
GRÜNING, T.; GILMORE, A.B.; MCKEE, M.Tobacco industry influence on science and scientists in Germany. Am J Public Health. 2006; 96: 20-32.

HONORATO, S. Judicialização da Política de Assistência Farmacêutica: discussão sobre as causas de Pedir no Distrito Federal. 2014. 99f. [Dissertação]. Faculdade de Ciências da Saúde da Universidade de Brasília. Brasília, 2014.

INTERNATIONAL BABY FOOD ACTION NETWORK (IBFAN). The Scaling Up Nutrition (SUN) initiative IBFAN's concern about the role of businesses, novembro, 2012. Disponível em: <http://www.ibfan.org/art/SUNIBFAN_281112.pdf>. Acesso em março de 2016.

IURCONVITE, A. S. A evolução histórica dos direitos sociais: da Constituição do Império à Constituição Cidadã. In: Âmbito Jurídico, Rio Grande, XIII, n. 74, mar 2010.

<http://www.ambitojuridico.com.br/site/index.php?n_link=revista_artigos_leitura\&artig o_id=7417>. Acesso em março de 2016.

LAFER, C. A reconstrução dos direitos humanos: um diálogo com o pensamento de Hannah Arendt. São Paulo: Companhia das Letras, 1988. p. 127.

LEAL, R. G. Condições e possibilidades eficaciais dos direitos fundamentais sociais: os desafios do Poder Judiciário no Brasil. Porto Alegre: Livraria do Advogado Editora, 2009.

LEÃO, M. M.; RECINE, E. O direito humano à alimentação adequada. In: TADDEI, J. A.; LANG, R. M. F.; LONGO-SILVA, G.; TOLONI, M. H. A. Nutrição em Saúde Pública. São Paulo: Rubio, 2011, p. 471-488.

LEÃO, M. O direito humano à alimentação adequada e o sistema nacional de segurança alimentar e nutricional. Brasília: ABRANDH, 2013. 263 p.

LEFÉVRE, F.; LEFÉVRE, A. M. C.; TEIXEIRA, J. J. V. O Dicurso do Sujeito Coletivo: uma nova abordagem metodológica em pesquisa qualitativa. Caxias do Sul: EDUCS, 2000.

LEFÉVRE, F.; LEFÉVRE, A. M. C. O Dicurso do Sujeito Coletivo: um novo enfoque em pesquisa qualitativa (desdobramentos). Caxias do Sul: EDUCS, 2003. P. 13-35.

LIRA, J. A. A Concretização e a Judicialização do Direito Constitucional à Alimentação no Brasil. Escola da Magistratura do Estado do Rio de Janeiro. [PósGraduação]. Rio de Janeiro, 2013.

LOPES, J. R. L. O Direito na História: lições introdutórias. 2 ed. São Paulo: Max Lomonad, 2002. p.322.

MACEDO, E. I. de; LOPES, L. C.; BARBERATO FILHO, S. Análise técnica para a tomada de decisão do fornecimento de medicamentos pela via judicial. Rev Saúde Pública 2011; 45(4): 706-13. 
MACHADO M.A.A.; ACURCIO, F.A.; BRANDÃO, C.M.R.; FALEIROS, D.R. Judicialização do acesso a medicamentos no Estado de Minas Gerais, Brasil. Rev. Saúde Pública 2011; 45(3):590-8.

MACIEL, D.; KOERNER, A. Sentidos da judicialização da política: duas análises. Lua Nova 2002; 57:113-133.

MÂNICA, F. B. O setor privado nos serviços públicos de saúde. Belo Horizonte: Fórum, 2010.

MANIGLIA, E. As interfaces do direito agrário e dos direitos humanos e a segurança alimentar. São Paulo: Cultura Acadêmica, 2009. p. 125.

MARQUES, O.R.A.; MELO, M.B.; SANTOS, A.P.S. Ações judiciais no âmbito do Sistema Único de Saúde do Brasil, bases legais e implicações: um estudo de caso em um tribunal da Região Sudeste. Rev. Direito Sanit., São Paulo, v. 12, n. 1, jun. 2011.

MARQUES, S. B. A relação do sistema jurídico e do sistema político na garantia do direito social à assistência farmacêutica: o caso do Estado de São Paulo. 2005. 261f. [Dissertação]. Faculdade de Saúde Pública da Universidade de São Paulo. São Paulo, 2005.

MARQUES, S.B.; DALLARI, S.G. Garantia do direito social à assistência farmacêutica no Estado de São Paulo. Rev. Saúde Pública 2007;41(1):101-7.

MARQUES, S. B. Judiacialização do Direito à Saúde. Revista de Direito Sanitário, São Paulo v. 9, n. 2 p. 65-72 Jul./Out. 2008.

MARQUES, S.B. O direito ao acesso universal a medicamentos no Brasil: diálogos entre o direito, a política e a técnica médica. 2011. 396f. [Tese]. Faculdade de Saúde Pública da Universidade de São Paulo, 2011.

MARTINS, A. S.; REZENDE, N. A. de; TORRES, H. O. G. Sobrevida e complicações em idosos com doenças neurológicas em nutrição enteral. Rev. Assoc. Med. Bras. 2012; 58 (6): 691-97.

MEDEIROS, M.; DINIZ, D.; SCHWARTZ, I.V.D. A tese da judicialização da saúde pelas elites: os medicamentos para mucopolissacaridose. Ciência \& Saúde Coletiva, 2013; 18(4):1089-1098.

MELO, M.; NASTARI, M.; MASSULA, L. A participação da mulher na magistratura brasileira - (considerações a respeito de dados parciais de 1999 a 2004). Revista Jurídica Virtual - Brasília, vol. 6, n. 70, mar. 2005.

MESSEDER, A.M.; OSORIO-DE-CASTRO, C. G.S.; LUIZA, V. L. Mandados judiciais como ferramenta para garantia do acesso a medicamentos no setor público: a experiência do Estado do Rio de Janeiro, Brasil. Cad. Saúde Pública, Rio de Janeiro, 21(2): 525-534, mar-abr, 2005. 
MINAYO, M.C.S. O desafio do conhecimento: pesquisa qualitativa em saúde. São Paulo: Hucitec/Rio de Janeiro: ABRASCO, 1992.

MINAYO, M. C. S. O desafio do conhecimento: pesquisa qualitativa em saúde. 9. ed. revista e aprimorada. São Paulo: Hucitec, 2006.

MORAES, M. C. B. de. O conceito de dignidade humana: substrato axiológico e conteúdo normativo. In: SARLET, I. W. (Org.). Constituição, direitos fundamentais e direito privado. Porto Alegre: Livraria do Advogado, 2003. p. 105-147.

MORAES, A. Direitos humanos fundamentais: teoria geral, comentários aos arts. $1^{\circ}$ ao $5^{\circ}$ da Constituição da República Federativa do Brasil, doutrina e jurisprudência. 7 ed. São Paulo: Atlas, 2006.

MORAES, A. Direito Constitucional. 26aㅜ ed. São Paulo: Atlas, 2010.

NETTO, L. C. P. O principio de proibição de retrocesso social. Porto Alegre: Livraria do Advogado Editora, 2010.

OLIVEIRA, V. C. A comunicação midiática e o Sistema Único de Saúde, Interface Comunicação, Saúde, Educação, v.4, n.7, p.71-80, 2000.

OLIVEIRA, M. D. Direito Fundamental à Saúde e suas faces: uma análise conjunta à irretroatividade do direito fundamental social à saúde. In: GOTTEMS, C.J.; SIQUEIRA, D.P. (Coord.). Direitos Fundamentais da Normatização à Efetividade nos 20 anos da Constituição Brasileira. Birigui, SP: Boreal Editora, 2008. P. 2010220.

OLIVEIRA, L. M. de; ANDRADE, E.I.G.; MILAGRES, M.O. Ministério Público e Políticas de Saúde: implicações de sua atuação resolutiva e demandista. Rev. Dir. Sanit., São Paulo v.15 n.3, p. 142-161, nov. 2014/fev. 2015.

ORGANIZAÇÃO MUNDIAL DA SAÚDE (OMS). Carta da Organização Mundial de Saúde, 1946. Disponível em: <http://www.onuportugal.pt/oms.doc>. Acesso em: 28 fev. 2016.

ORGANIZAÇÃO DAS NAÇÕES UNIDAS. Declaração dos Direitos Humanos, 1948.

PEPE, V. L. E.; VENTURA, M.; FIGUEIREDO, T. A.; SOUZA, V. R.; SIMAS, L.; OSOVIO-DE-CASTRO, C. G. S. Caracterização de demandas judiciais de fornecimento de medicamentos "essenciais" no Estado do Rio de Janeiro, Brasil. Cad. Saúde Pública, Rio de Janeiro, 26(3):461-471, mar, 2010.

PEREIRA, T. N.; NASCIMENTO, F. A. do; BANDONI, D. H. Conflito de interesses na formação e prática do nutricionista: regulamentar é preciso. Ciência \& Saúde Coletiva. No prelo 2016.

PESSINI, L.; BARCHIFONTAINE, C. P. Problemas Atuais de Bioética. 6. Ed. São Paulo: Loyola, 2002. 
PETEAN, E.; ARAÚJO, L. F. S.; BELLATO, R.; WUNSCH, C. G. et al. Direito à saúde: demanda por suplementos no Tribunal de Justiça. Rev. Eletr. Enf. [Internet]. 2012 jan/mar;14(1):68-76.

PETRAMALE, C. A. O desafio de melhorar a comunicação e a transparência. Demetra, 2014; 9 (Supl.1); 219-222.

PINHO, R. C. R. Teoria Geral da Constituição e Direitos Fundamentais. 11ª ed., São Paulo: Saraiva, 2011. (Coleção sinopses jurídicas; v. 17).

PIOVESAN, A.; TEMPORINI, E.R. Pesquisa exploratória: procedimento metodológico para o estudo de fatores humanos no campo da saúde pública. Revista de Saúde Pública, São Paulo, v.29, n.4, p. 318-25, agosto 1995.

PIOVESAN, F. Direitos Humanos e o Direito Constitucional Internacional. 6 ed. São Paulo: Max Limonad, 2004.

PSCHEIDT, K. R. Agência Nacional de Saúde Suplementar: o Estado e a Saúde Privada no Brasil. Curitiba - Edição do Autor. Brasil, 2104. 90p.

REA, M. F.; TOMA, T. S. Proteção do leite materno e ética. Rev. Saúde Pública, São Paulo, v. 34, n. 4, p. 388-395, ago. 2000.

ROMERO, L. C. Judicialização das Políticas de Assistência Farmacêutica: o caso do Distrito Federal. Brasília, maio /2008.

ROOSEVELT, F.D. "State of the Union Message to Congress," January 11, 1944. In: PETERS, G.; WOOLLEY, J.T. The American Presidency Project. Disponivel em: $<$ http://www.presidency.ucsb.edu/ws/?pid=16518>. Acesso em 31 de março de 2016.

ROTHMAN, D. J. Consequences of industry relationships for public health and medicine. Am J. Public Health. 2012; 102(1): 55.

RIOS, R. R. Direito à saúde, universalidade, integralidade e políticas públicas: princípios e requisitos em demandas judiciais por medicamentos. Revista de Doutrina da 4플 Região, Porto Alegre, n. 31, agosto. 2009.

SABADELL, Ana Lúcia. Manual de Sociologia Jurídica: Introdução a uma leitura externa do Direito. 2.ed., São Paulo: Revista dos Tribunais, 2002. p.21.

SANT'ANA, J. M. B. Essencialidade e assistência farmacêutica: um estudo exploratório das demandas judiciais individuais para acesso a medicamentos no Estado do Rio de Janeiro. Rio de Janeiro: s.n., 2009. Xii, 93 f.

SANT'ANA, J.M.B.; PEPE, V.L.E.; OSORIO-DE-CASTRO, C.G.S.; VENTURA, M. Essencialidade e assistência farmacêutica: considerações sobre o acesso a medicamentos mediante ações judiciais no Brasil. Rev. Panam. Salud Publica. 2011: 29(2): 138-44.

SILVA, J. A. da. Curso de direito constitucional positivo. $17^{\text {a }}$ ed., rev. e atual. São 
Paulo: Malheiros, 2000. p. 185.

SILVA, J. A. Jurisdição Constitucional da Liberdade no Brasil. Revista do Centro de Estúdios Políticos y Constitucionales, [s.d] p. 9. Disponível em: $<$ http://www.cepc.es/rap/Publicaciones/Revistas/8/AlB_003_009.pdf>. Acesso em março de 2016.

SILVA, J. A. Curso de Direito Constitucional Positivo. 23. ed. São Paulo: Malheiros, 2004.

SILVA, J. A. Comentário Constextual à Constituição.7ed. São Paulo: Malheiros, 2010.

SILVA, J. F. Aplicabilidade das Normas Constitucionais. 3. ed. São Paulo: Malheiros, 1999.

SILVA, M. V. da. O processo decisório judicial e a assessoria técnica: a argumentação jurídica e médico-sanitária na garantia do direito à assistência terapêutica no Sistema Único de Saúde. 2012. 198f. [Tese]. Fundação Oswaldo Cruz. Rio de Janeiro, 2012.

SIMIONI, A. M. C.; et al. Metodologia qualitative nas pesquisas em saúde coletiva: considerações teóricas e instrumentais. São Paulo, 1997. (Série Monográfica do Departamento de Prática de Saúde Pública da FSP, 2).

SPARAPANI, P. O modelo de estado brasileiro contemporâneo: um enfoque crítico. Revista Âmbito Jurídico - Revista jurídica eletrônica mensal. Rio Grande, XV, n. 98, mar 2012.

SIQUEIRA, P. S. F. de. Judicialização em Saúde no Estado de São Paulo. In: CONASS. Direito à Saúde. Coleção Para Entender a Gestão do SUS, 2015.

SOARES, J. C. R. S.; DEPRÁ, A. S. Ligações perigosas: indústria farmacêutica, associações de pacientes e as batalhas judiciais por acesso a medicamentos. Physis Revista de Saúde Coletiva, Rio de Janeiro, 22 [1]: 311-329, 2012.

TERRAZAS, F. V. Novos elementos no cenário da judicialização da saúde: análise das decisões dos Tribunais Superiores. In: SANTOS, L.; TERRAZAS. F.V.. (Org.). Judicialização da Saúde no Brasil. 1ed.Campinas: Saberes Editora, 2014, v., p. 307-330.

TRIVINOS, A. N. S. Introdução à pesquisa em ciências sociais. São Paulo: Atlas, 1987.

VAINER, B. Z. Breve histórico acerca das constituições do brasil e do controle de constitucionalidade brasileiro. Revista Brasileira de Direito Constitucional, n. 16 jul./dez. 2010.

VALENTE, F. L. S. Do combate à fome à Segurança Alimentar e Nutricional: o Direito Humano à Alimentação Adequada. In: Direito Humano à Alimentação Adequada: desafios e conquistas. São Paulo: Cortz Editora, 2002, p. 40-43. 
VENTURA, M.; SIMAS, L.; PEPE, V. L. E.; SCHRAMM, F. R. Judicialização da saúde, acesso à justiça e a efetividade do direito à saúde. Physis Revista de Saúde Coletiva, Rio de Janeiro, 20 [1]: 77-100, 2010.

VIEIRA, F. S.; ZUCCHI, P. Distorções causadas pelas ações judiciais à política de medicamentos no Brasil. Rev. Saúde Pública 2007;41(2):214-22.

WANG, D. W. L. Poder Judiciário e políticas públicas de saúde: participação democrática e equidade. Cadernos Gestão Pública e Cidadania, v. 14, n. 54 jan./junho de 2009.

WANG, D. W. L.; VASCONCELOS, N. P. de; OLIVEIRA, V. E. de; TERRAZAS, F. V. Os impactos da judicialização da saúde no município de São Paulo: gasto público e organização federativa. Rev. Adm. Pública — Rio de Janeiro 48(5):1191-1206, set./out. 2014. 


\title{
APÊNDICES
}

APÊNDICE A - ARTIGO

\section{O Direito à Alimentação e à Saúde: histórico de sua garantia no Estado Democrático de Direito ${ }^{16}$}

\section{The Right to Food and Health: history and guaranteed by democratic rule of law}

\section{El derecho a la alimentación y la salud: historia y garantizado por el estado de derecho democrático}

\author{
Kimielle Cristina Silva ${ }^{17}$
}

Maria Célia Delduque Nogueira de Sá ${ }^{18}$

RESUMO: Os Direitos Fundamentais são considerados essenciais à pessoa humana, necessários para uma existência digna, livre e igual. A expressão "direitos fundamentais" possui vários sinônimos, dentre eles os termos liberdades públicas, direitos humanos e direitos subjetivos públicos. O termo direitos fundamentais é o mais claro pela sua abrangência, pois a expressão direito indica tanto a situação em que se deseja a defesa do cidadão perante o Estado como os interesses jurídicos de caráter social, politico ou difuso, protegidos pela Constituição. Os Direitos Sociais estão apresentados no $\operatorname{artigo} 6^{\circ}$ da Constituição da República Federativa do Brasil, de 05 de outubro de 1988 e sua garantia está explicitada por todo o ordenamento jurídico. A proteção dos Direitos Sociais deve ser concretizada pelo Estado. Os Direitos Sociais previstos na Norma Suprema do País são: o direito à educação, o direito à saúde, o direito à alimentação, o direito ao trabalho, o direito à moradia, o direito ao lazer, o direito à segurança, o direito à previdência social, o direito a proteção à maternidade e

\footnotetext{
${ }^{16}$ Este artigo foi elaborado a partir da revisão bibliográfica da dissertação de Mestrado "Acesso às fórmulas nutricionais para usuários do SUS: percepções do poder judiciário frente ao crescimento da judicialização", defendida no Programa de Pós-Graduação em Saúde Coletiva da Universidade de Brasília. Brasília, 2016.

${ }^{17}$ Nutricionista, Mestrado em Saúde Coletiva, Universidade de Brasília.

${ }^{18}$ Advogada, Doutorado em Saúde Pública pela USP e Pós-doutorado em Direito pela Universidad de Cantabria. Coordenadora do Programa de Direito Sanitário da Fiocruz.-Brasília.
} 
à infância, o direito à assistência aos desamparados, entre outros. Os direitos à alimentação e à saúde constituem como direitos de segunda dimensão, denominado de direito social, que não deve ser entendido apenas como uma obrigação local ou regional. Desde a publicação da Constituição Federal de 1988, particularmente no âmbito da jurisdição constitucional, tem sido comum a busca da sociedade pela efetivação dos direitos sociais.

\section{PALAVRAS CHAVE: Direitos Sociais, Direito à Saúde, Direito à Alimentação, Judicialização}

ABSTRACT: The fundamental rights are considered essential to the human person needed for a dignified, free and equal existence. The term "fundamental rights" has several synonyms, including the terms of public freedoms, human rights and public subjective rights. The term "fundamental rights" is the clearest for its scope, for the right expression indicates both the situation in which you want the protection of the citizen to the state as the legal interests of social, political or diffuse, protected by the Constitution. Social Rights are presented in Article 6 of the Constitution of the Federative Republic of Brazil, of 5 October 1988 and the guarantee is explicit throughout the legal system. The protection of social rights must be established by the State. The social rights provided for in the country's Supreme Standard are: the right to education, the right to health, right to food, the right to work, the right to housing, the right to leisure, the right to safety, the right to security social, the right to protection of motherhood and childhood, the right to assistance to the destitute, among others. The rights to food and health are as second dimension of rights, called social right, and should not be understood only as a local or regional obligation. Since the publication of the 1988 Federal Constitution, particularly in the context of constitutional jurisdiction has been common the search of society for the realization of social rights.

KEYWORDS: Social Rights, Right to Health, Right to Food, Legalization

RESUMEN: Los derechos fundamentales se consideran esenciales para el ser humano necesario para una vida digna, libre e igual. El término "derechos fundamentales" tiene varios sinónimos, incluyendo los términos de las libertades públicas, los derechos humanos y los derechos públicos subjetivos. El término "derechos fundamentales" es la más clara de su ámbito de aplicación, para la expresión de la derecha indica tanto la situación en la que desea que la protección de los ciudadanos al Estado como los intereses legales de la vida social, política o difusa, protegido por la Constitución. Derechos sociales se presentan en el artículo 6 de la Constitución de la República Federativa del Brasil, de 5 de octubre de 1988 y la garantía 
es explícita en todo el sistema legal. La protección de los derechos sociales debe ser establecido por el Estado. Los derechos sociales previstos en la Norma Suprema del país son: el derecho a la educación, el derecho a la salud, derecho a la alimentación, el derecho al trabajo, el derecho a la vivienda, el derecho al ocio, el derecho a la seguridad, el derecho a la seguridad social, el derecho a la protección de la maternidad y la infancia, el derecho a la asistencia a los indigentes, entre otros. Los derechos a la alimentación y la salud son como segunda dimensión de los derechos, llamado derecho social, y no deben entenderse sólo como una obligación local o regional. Desde la publicación de la Constitución Federal de 1988, particularmente en el contexto de la jurisdicción constitucional ha sido común la búsqueda de la sociedad para la realización de los derechos sociales.

PALABRAS CLAVE: Derechos Sociales, derecho a la salud, derecho a la alimentación, la legalización

\section{OS DIREITOS FUNDAMENTAIS}

Os Direitos Fundamentais são considerados essenciais à pessoa humana, necessários para uma existência digna, livre e igual. Tais direitos se concretizaram sistematica e normativamente na passagem do Estado Liberal para o Estado de Bem-Estar Social no início do século XX.

É importante destacar que nem sempre os Direitos Fundamentais foram considerados relevantes. A evolução histórica desses direitos despertou a responsabilidade de uma consciência coletiva para alcance da dignidade humana e possibilitou a sua consolidação na Constituição. A sua garantia foi realizada por meio de instrumentos e mecanismos históricos que possibilitaram normas de caráter público, capazes de se manifestar em condições para desenvolver ações efetivas.

\section{A Evolução dos Direitos Fundamentais}

No século XVIII a ideologia dos direitos do Homem foi base para a reformulação das instituições politicas. O processo de desenvolvimento da sociedade e o Estado de Direito (ressalta-se que os Direitos Fundamentais precedem a este) induziram a precaução com a proteção dos indivíduos e do meio que vivem, gerando normativas que consagraram direitos comuns aos homens, chamados de direitos fundamentais ${ }^{1}$ (p.93).

A expressão "direitos fundamentais" possui vários sinônimos, dentre eles as expressões liberdades públicas, direitos humanos e direitos subjetivos públicos. Ainda assim, a expressão 
“direitos fundamentais" é a mais clara pela sua abrangência, pois o termo direito indica tanto a situação em que se deseja a defesa do cidadão perante o Estado como os interesses jurídicos de caráter social, politico ou difuso, protegidos pela Constituição. Já o termo fundamental caracteriza a precisão desses direitos à condição humana ${ }^{2}$ (p. 109-110).

Apesar de algumas pessoas retratarem as diferenças entre direitos humanos e direitos fundamentais, percebe-se que em muitos conceitos e teorias são utilizadas de forma semelhantes. Alguns afirmam que existe um ponto em comum entre os direitos humanos e direitos fundamentais no aspecto material, ou seja, os dois reconhecem os valores de liberdade e igualdade e pretendem proteger e promover a dignidade da pessoa humana, mas divergem no aspecto formal, que se refere a sua posição dentro da ordem jurídica. Quando é reconhecido no direito interno, denominam-se direitos fundamentais, quando legitimados em tratados internacionais (no direito internacional), denomina-se de direitos humanos ${ }^{3}$.

Coelho ${ }^{4}$ descreve que os direitos humanos são inerentes à própria natureza humana e por isso são invioláveis, intemporais e universais. Já os direitos fundamentais são os direitos ordenados e presentes numa ordem jurídica concreta.

Comparato $^{5}$ relata a distinção entre direitos fundamentais e humanos na perspectiva da doutrina germânica:

É ai que se põe a distinção, elaborada pela doutrina jurídica germânica, entre os
direitos humanos e direitos fundamentais (Grundrechte). Estes últimos são os
direitos humanos reconhecidos como tais pelas autoridades às quais se atribui o
poder politico de editar normas, tanto no interior dos Estados quanto no plano
internacional; são os direitos humanos positivados nas Constituições, nas leis, nos
tratados internacionais. Segundo outra terminologia, fala-se de direitos fundamentais
típicos e atípicos, sendo esses os direitos humanos ainda não declarados em textos
normativos (p.70-71). Ainda que exista uma discussão teórica sobre a distinção conceitual entre os direitos humanos e direitos fundamentais é necessário ressaltar que no Brasil cabe ao Estado Democrático de Direito proteger tanto os direitos fundamentais, positivados no texto constitucional, quanto os direitos humanos positivados nos tratados internacionais. Logo, os dois conceitos são protegidos pelo ordenamento jurídico brasileiro ${ }^{6}$.

Nota-se que a evolução dos direitos fundamentais possui uma classificação progressiva, chamada de dimensão ou geração ${ }^{19}$, em que foram aos poucos reconhecidos

\footnotetext{
${ }^{19} \mathrm{O}$ autor dessa distinção em dimensões ou gerações de direitos foi Karel Vazak em 1979, mas foi Norberto Bobbio quem publicou essa distinção (A Era dos Direitos). No Brasil o principal autor que trata desse assunto é
} 
constitucionalmente. Sendo esses divididos em direitos fundamentais de primeira, segunda e terceira geração.

Os direitos fundamentais de primeira geração surgiram no Estado Liberal e correspondem aos direitos de liberdade, compreendendo os direitos individuais e políticos, dentro do modelo clássico da Constituição. São impostos limites à atuação do Estado, protegendo direitos considerados indispensáveis a cada pessoa humana. Exemplos: liberdade de locomoção e inviolabilidade do domicilio ${ }^{7}$ (p. 98).

$\mathrm{Na}$ implantação do Estado Social são reconhecidos os direitos de segunda geração, os quais têm por fundamento a preocupação com as necessidades mínimas do ser humano para uma vida digna. Significam uma prestação do Estado em favor dos menos favorecidos pela ordem social e econômica. Surgem os direitos sociais, que exigem a atuação ativa do Estado na redução dos problemas sociais, acentuando o princípio da igualdade. São exemplos de direitos sociais: salário mínimo, aposentadoria, férias remunerada ${ }^{8,7(\mathrm{p} .98)}$.

Os direitos de terceira geração referem-se aos direitos de fraternidade ou solidariedade. São voltados para a coletividade em massa e surgiram em razão dos processos de industrialização e urbanização, em que os conflitos sociais não eram resolvidos satisfatoriamente dentro da antiga tutela jurídica que era voltada apenas para defesa dos direitos individuais. São exemplos: direito ao um meio ambiente saudável, à paz, à saúde, à alimentação, à educação pública $^{4,7(p .99)}$.

Observa-se que a evolução dos direitos fundamentais foram gradativamente ampliados e associados a valores de igualdade, fraternidade e cidadania, além da proteção dos diretos da coletividade. Esses direitos são de singular importância para o Estado de Direito e dispõe como valor estrutural no ordenamento jurídico, informando e justificando o Estado Constitucional:

O Estado Constitucional, vertebrado pelos princípios da juridicidade, da democracia e da solidariedade, pode ser designado Estado de Direitos Fundamentais, considerando-se a centralidade assumida pelos direitos fundamentais como fim e medida de estruturação, organização e atuação do estado e do seu relacionamento com a sociedade e com seus indivíduos ${ }^{8}$ (p.34).

Paulo Bonavides. Quando se fala em geração dá a entender que uma substitui a outra, entretanto, elas coexistem, assim muitos dizem que são dimensões e não geração. 


\section{Evolução Constitucional Brasileira e os Direitos Sociais Fundamentais}

A Constituição de 1824 foi a mais duradoura da história brasileira e foi influenciada pela doutrina liberal, com os princípios de liberdade, igualdade e fraternidade. Apesar de que naquela época no Brasil, as relações sociais, politicas e econômicas eram marcadas pela desigualdade. O status de cidadão era concedido apenas aos homens ricos e livres. O imperador possuía todos os poderes ${ }^{9}$.

Na Constituição de 1891 deu início o modelo republicano, o presidencialismo, a forma federativa de Estado. Adotou-se a tripartição dos poderes, na concepção de Montesquieu, formada pelos poderes Executivo, Legislativo e Judiciário.

Em 1930 chega ao fim a Primeira Republica e o Brasil passa a viver por quatro anos o período da ditadura. Já a Constituição de 1934, trouxe inovações sociais e trabalhistas e estabeleceu o Estado Social no Brasil. O Estado passou a desempenhar condutas voltadas à proteção do cidadão, mais intervencionista na economia e susceptível às demandas sociais ${ }^{9}$.

Em 1937 o país sofre um golpe de estado e passa a ser governado por meio de decretos-leis, findando, de certa forma, a tripartição dos poderes e reduzindo os direitos e as garantias individuais.

A Constituição de 1946 dispõe sobre o fim da Ditadura no Brasil. A atenção aos direitos sociais ressurge e o rol de direitos e garantias individuais amplia-se.

Após 20 anos, desponta a Constituição de 1967. Sua atenção era voltada à proteção da indústria e ao comércio em detrimento do homem. Novamente os direitos individuais foram limitados.

Por fim, a Constituição de 1988 rompe o período politico anterior e busca diminuir as injustiças sociais. Tende-se pelo modelo de produção capitalista, no qual o Estado desempenha o papel de agente normativo e regulador. O novo texto constitucional dá ênfase e garante os direitos sociais.

Legitima-se o Estado Democrático de Direito que tem como princípios a soberania, a cidadania, os valores sociais de trabalho e da livre iniciativa e o pluralismo politico. Nota-se que a Constituição da República Federativa de 1988, Constituição Cidadã, é a que ampliou os Direitos Sociais e teve por objetivo fundamental a efetivação de tais Direitos ${ }^{9}$. 


\section{Os Direitos Sociais}

Os Direitos Sociais são direitos de toda a sociedade, que visam melhorar as condições de vida e de trabalho e devem ser garantidos e protegidos pelo Estado. A sociedade que detém esses direitos é conhecida por ser um Estado Social de Direito e deve garantir a igualdade social a todos inclusive aos hipossuficientes.

Para Moraes ${ }^{10}$ :

Direitos sociais são direitos fundamentais do homem, caracterizando-se como verdadeiras liberdades positivas, de observância obrigatória em um Estado Social de Direito, tendo por finalidade a melhoria de condições de vida aos hipossuficientes, visando à concretização da igualdade social, e são consagrados como fundamentos do Estado democrático, pelo art. $1^{\circ}$, IV, da Constituição Federal (p. 197).

Os Direitos Sociais estão apresentados no artigo $6^{\circ}$ da Constituição da República Federativa do Brasil de 05 de outubro de 1988 e sua garantia está explicitada por todo o ordenamento jurídico.

\section{Os Direitos Sociais na Constituição de 1988}

Os Direitos Sociais situam-se em aspectos constitucionais e encontram expressamente disciplinados no artigo $6^{\circ}$, caput, da Constituição Cidadã brasileira. $\mathrm{O}$ referido artigo expõe que "são direitos sociais a educação, a saúde, a alimentação, o trabalho, a moradia, o lazer, a segurança, a previdência social, a proteção à maternidade e à infância, a assistência aos desamparados, na forma desta Constituição". O caput do artigo $6^{\circ}$ da Constituição Federal de 1988 foi implementado na Norma Maior por meio da Emenda Constitucional de número 64, de 4 de fevereiro de 2010 que introduziu mais um Direito Social, o direito à alimentação.

\section{O Direito à Alimentação}

\section{O Direito à Alimentação no Contexto Internacional}

O direito fundamental à alimentação constitui como direito social, e não deve ser entendido apenas como uma obrigação local ou regional. A responsabilidade pelo direito à alimentação aparece em vários instrumentos internacionais ${ }^{20}$ de proteção dos direitos fundamentais, de âmbito global e nacional.

\footnotetext{
20 Destacam-se alguns instrumentos internacionais (declarações, pactos e convenções) de incontestável importância, a saber: além da Declaração Universal dos Direitos Humanos (1948) e do Pacto Internacional dos Direitos Econômicos, Sociais e Culturais (1966), tem-se a Declaração das Nações Unidas dos Direitos dos
} 
Ele constitui como um direito fundamental básico, firmado e legitimado em vários documentos internacionais tais como declarações, pactos e convenções ao assumirem a premissa de que todos os direitos fundamentais são universais, indivisíveis, interdependentes e interrelacionados e, cuja validade é perene.

A Declaração Universal dos Direitos Humanos validada pela Assembleia-Geral das Nações Unidas em 1948 apresenta uma referência ao direito à alimentação, no artigo $25^{11}$ :

Toda pessoa tem direito a um padrão de vida capaz de assegurar a si e a sua família saúde e bem-estar, inclusive alimentação, vestuário, habitação, cuidados médicos e os serviços sociais indispensáveis, e direito à segurança em caso desemprego, doença, invalidez, viuvez, velhice ou em outros casos de perda de outros meios de subsistência fora de seu controle.

A Declaração Universal de Direitos Humanos é compreendida como interpretação autorizada da expressão "direitos humanos e liberdades fundamentais", incluída na Carta das Nações Unidas, tendo em si, força jurídica, embora seja apenas uma recomendação das Nações Unidas, aceita sob a forma de resolução de sua Assembleia-Geral.

O direito à alimentação tem duas linhas no direito internacional: o direito a uma alimentação adequada e o direito fundamental de estar livre da fome. Essas duas vertentes foram consideradas no Pacto Internacional sobre os Direitos Econômicos, Sociais e Culturais (PIDESC), no artigo $11^{12}$ :

Os Estados-Parte do presente Pacto reconhecem o direito de toda pessoa a um nível de vida adequado para si próprio e sua família, inclusive à alimentação, vestimenta e moradia adequadas, assim como a sus melhoria continua de sua condição de vida. Os Estados- Parte tomarão medidas apropriadas para assegurar a consecução desse direito, reconhecendo, nesse sentido, a importância essencial da cooperação internacional fundada no livre consentimento;

Portadores de Deficiência (1975) que proclamou o tema da alimentação como direito. Nas previsões da Convenção sobre a Eliminação de Todas as Formas de Discriminação contra as Mulheres (1979), na Declaração sobre o Direito ao Desenvolvimento (1986) que assegurou o direito à alimentação. A Declaração dos Direitos da Criança (1959) e a Convenção das Nações Unidas sobre os Direitos da Criança (1989) reconheceram o direito de toda a criança ter um padrão de vida adequado ao seu desenvolvimento físico, mental, espiritual, moral e social. A Convenção $\mathrm{n}^{\mathrm{o}} 169$ da Organização Internacional do Trabalho (1989) concernente aos povos e às tribos indígenas em países, também proclama o direito à alimentação. Outras reuniões, documentos e cúpulas internacionais também trataram do tema: Conferência Mundial sobre Alimentação (1974), Declaração de Princípios e Programas de Ação da Conferência Mundial sobre Reforma Agrária e Desenvolvimento Rural (1979), Conferência Internacional sobre Nutrição (1992), Declaração e Programa de Ação de Viena da Conferência Mundial sobre Direitos Humanos (1993), Declaração e Programa de Ação da Cúpula Mundial para o Desenvolvimento Social-Copenhague (1995), Conferência de Pequim sobre a Mulher (1995), Declaração de Roma sobre Segurança Alimentar e o Plano de Ação da Cúpula Mundial de Alimentação (1996) e a Declaração do Milênio das Nações Unidas (2000). No plano regional tem-se o Protocolo de San Salvador, protocolo adicional à Convenção Americana sobre Direitos Humanos (1969), que no art. 12 estabelece que "todos têm direito à adequada nutrição que garanta possibilidade de gozar do maior nível de desenvolvimento físico, emocional e intelectual". Por sua vez, no espaço eurocomunitário tem-se a Carta Social Europeia que foi revista em 1996. 
Os Estados-Parte do presente pacto, reconhecendo o direito fundamental de toda pessoa de estar protegida contra a fome, adotarão, individualmente e mediante cooperação internacional, as medidas, inclusive programas concretos, que se façam necessárias para:

a). Melhorar os métodos de produção, conservação e distribuição de gêneros alimentícios pela plena utilização dos conhecimentos técnicos e científicos, pela difusão de princípios de educação nutricional e pelo aperfeiçoamento e pela reforma dos regimes agrários, de maneira que se assegurem a exploração e a utilização mais eficazes dos recursos naturais;

b). Assegurar uma repartição equitativa dos recursos alimentícios mundiais em relação às necessidades, levando-se em conta os problemas tanto dos países importadores quanto os exportadores dos gêneros alimentícios.

O Brasil foi um dos Estados Parte do PIDESC, aderindo ao pacto em 24 de janeiro de 1992, incluído à legislação nacional pelo Decreto nº 591, de 06 de julho de 1992.

O Comitê de Direitos Econômicos, Sociais e Culturais (CDESC) ${ }^{21}$ das Nações Unidas, responsável por monitorar e gerar efeito ao PIDESC, abordou sobre o direito a uma alimentação adequada em seu documento, propiciando as bases conceituais e constituindo os meios para a sua realização e utilização. O Comitê estabeleceu que "direito humano à alimentação adequada é de importância crucial para a fruição de todos os direitos”.

Em 1996, na Cúpula Mundial sobre Alimentação presidida pela Organização das Nações Unidas para Agricultura e Alimentação (Food and Agriculture Organization of the United Nations -FAO) foi discutido a fome do mundo e, num ato protocolar, todos os 185 países presentes e a Comunidade Europeia comprometeram-se a erradicar a fome de todos os países, estabelecendo a Declaração de Roma sobre Segurança Alimentar. Reafirmando o direito à alimentação adequada e o direito básico de todos estarem livres da fome ${ }^{13}$ (p.125).

A Cúpula Mundial da Alimentação ${ }^{22}$ sobre Segurança Alimentar, realizada em 2009, renovou, por meio da Declaração da Cúpula Mundial sobre Segurança Alimentar o compromisso feito na Cúpula Mundial da Alimentação de 1996 de erradicar a fome de forma sustentável. A Declaração também menciona a necessidade de um aumento no fundo para agricultura nacional e internacional, novos investimentos no setor rural, melhoria da administração das questões globais.

\footnotetext{
${ }^{21}$ O Comitê de Direitos Econômicos, Sociais e Culturais (CDESC) é o órgão que supervisiona o cumprimento do

Pacto Internacional de Direitos Econômicos, Sociais e Culturais (PIDESC) por meio da elaboração de relatórios ou pareceres com conclusões e recomendações para os Estados. Não está previsto no Pacto, senão que foi criado pela Resolução 1985/17, de 28 de Maio de 1985, do Conselho Econômico e Social (ECOSOC) das Nações Unidas para o desempenho das funções apresentadas na parte IV do Pacto (artigos 16 a 25).

${ }^{22}$ FAO. Declaração de Roma sobre Segurança Alimentar Mundial e Plano de Ação da Cúpula Mundial da Alimentação. $\quad$ Roma, $1996 . \quad$ Disponível em: <http://www.fao.org/DOCREP/003/W3613P/W3613P00.HTM\#Note1>.
} 


\section{O Direito à Alimentação no Contexto Nacional}

A Constituição do Brasil (1988) abrangeu vários direitos consagrados na Declaração Universal dos Direitos Humanos em suas disposições e estabeleceu mecanismos processuais que buscam dar poder a esses direitos. O principio da Constituição identifica o Brasil como um Estado Democrático de Direito, "destinado a assegurar o exercício dos direitos sociais e individuais, a liberdade, a segurança, o bem-estar, o desenvolvimento, a igualdade e a justiça" ${ }^{14}$. Segundo o artigo $6^{\circ}$ da Constituição:

São direitos sociais a educação, a saúde, a alimentação, o trabalho, a moradia, o lazer, a segurança, a previdência social, a proteção à maternidade e à infância, a assistência aos desamparados, na forma desta Constituição ${ }^{14}$.

O direito à alimentação, desde a promulgação da Constituição, em 1988, é previsto claramente no artigo 227: "é dever da família, da sociedade e do Estado assegurar à criança e ao adolescente, com absoluta prioridade, o direito à vida, à saúde, à alimentação" ${ }^{14}$. Além de algumas normas constitucionais, de forma não explícita, já reconheciam a alimentação como um direito constitucional, como as normas que determinam a função social da propriedade (artigo $5^{\circ}$, inciso XXIII), as que dispõem sobre a demarcação de terras indígenas (artigo 231) e dos territórios quilombolas (artigo 63 do Ato das Disposições Constitucionais Transitórias), as normas que dispõem sobre o meio ambiente (artigo 225), a dignidade da pessoa humana $\left(\operatorname{artigo~} 1^{\circ} \text {, inciso III }\right)^{14}$, estão relacionadas às questões do direito à alimentação.

A partir da $1^{\text {a }}$ Conferência Nacional de Alimentação e Nutrição em 1986 no Brasil e das Conferências Nacionais de Segurança Alimentar e Nutricional (II CNSAN - 2004 e III CNSAN - 2007), consolidou-se a alimentação como um direito de cidadania, com vista de encaminhamentos na Constituição brasileira de 1988.

Um marco foi à aprovação da Lei Orgânica de Segurança Alimentar e Nutricional (LOSAN) Lei $\mathrm{n}^{\mathrm{o}}$ 11.346/2006, de 15 de setembro de 2006 -, que incorporou os princípios dos instrumentos internacionais sobre o direito fundamental à alimentação (universalidade, indivisibilidade, inalienabilidade, interdependência e inter- relacionariedade), e criou o Sistema Nacional de Segurança Alimentar e Nutricional (SISAN) ao visar assegurar o direito fundamental à alimentação e estabelecer um conjunto de definições com diretrizes, princípios, objetivos e a própria composição do $\operatorname{SISAN}^{15}$. A LOSAN dispõe no seu artigo $2^{\text {o }}{ }^{16}$ :

A alimentação adequada é um direito fundamental do ser humano, inerente à dignidade da pessoa humana e indispensável à realização dos direitos consagrados na Constituição Federal, devendo o poder público adotar as políticas e ações que se 
façam necessárias para promover e garantir a segurança alimentar e nutricional da população.

Ressalta-se que o direito à alimentação era apenas mencionado e contido explicitamente em legislação infraconstitucional, e não era reconhecido no rol de direitos fundamentais na Constituição brasileira de 1988. Mas, em 4 de fevereiro de 2010, por meio da publicação da Emenda Constitucional (EC) $n^{\circ} 64 / 2010$, ao alterar o artigo $6^{\circ}$ da Constituição estabeleceu o direito à alimentação como direito fundamental social ${ }^{17}$ (p. 69). A nova redação do artigo $6^{\circ}$ da Constituição apresenta "são direitos sociais a educação, a saúde, a alimentação, o trabalho, a moradia, o lazer, a segurança, a previdência social, a proteção à maternidade e à infância, a assistência aos desamparados, na forma desta Constituição".

O direito à alimentação deve ser compreendido na igualdade. Para Dalmo Dallari ${ }^{19}$, não deve ser admitida a desigualdade social, que assegura tudo a alguns, desde a melhor condição econômica e preparo intelectual, negando tudo a outros.

Por isso, a Carta Magna, por meio do artigo $5^{\circ}, \S 1^{\circ}$, definiu que as normas definidoras dos direitos e garantias fundamentais possuem aplicabilidade imediata. Assim, essas normas deixam de ser meros programas e vinculam aos poderes públicos. Além disso, esses direitos foram incluídos no rol das cláusulas pétreas, não podem ser suprimidos, são intocáveis, conforme dispõe o artigo $6^{\circ}, \S^{\circ}$ da Constituição ${ }^{14}$. Além disso, a Constituição brasileira possibilita a todos provocar o Judiciário na falta de cumprimento pelo Estado desses direitos ${ }^{20}$.

No tocante ao direito à alimentação, sabe-se que sua garantia depende de políticas em diferentes setores relacionados à Segurança Alimentar e Nutricional (SAN) e demandam uma abordagem intersetorial. Atualmente, o Brasil adota o seguinte conceito de SAN:

A Segurança Alimentar e Nutricional consiste na realização do direito de todos ao acesso regular e permanente a alimentos de qualidade, em quantidade suficiente, sem comprometer o acesso a outras necessidades essenciais, tendo como base práticas alimentares promotoras de saúde que respeitem a diversidade cultural e que sejam ambiental, cultural, econômica e socialmente sustentáveis ${ }^{16}$.

Para Leão ${ }^{15}$, é necessário políticas que incidem sobre toda a cadeia produtiva de alimentos (produção, transformação, distribuição, abastecimento e consumo), e devem estar articuladas e complementadas com:

Políticas que incidem sobre a renda, gastos da população com alimentação, acesso à alimentação adequada, abastecimento público de água potável e outros meios de acesso a água, oferta de equipamentos públicos como cozinhas comunitárias, restaurantes populares, entre outros; 
Políticas de saúde que incidem sobre os determinantes sociais da saúde e de doenças, que garantam o acesso a serviços e atenção à saúde nos diferentes níveis, além de programas de suplementação nutricional, promoção de hábitos saudáveis e saneamento;

Políticas de educação que têm papel relevante na promoção do Direito Humano à Alimentação Adequada (DHAA). Maiores níveis de escolaridade estão relacionados a melhores índices de saúde. Desta forma, políticas de combate ao analfabetismo e educação básica contribuem para a garantia do Direito Humano à Alimentação Adequada (DHAA);

Políticas específicas para povos e comunidades tradicionais, que são de fundamental importância para a garantia do DHAA destas populações, geralmente mais ameaçadas, tanto devido às suas características particulares e quanto às iniquidades sofridas historicamente (p.37).

No contexto da saúde pública, merece destaque a Política Nacional de Alimentação e Nutrição (PNAN), que tem como pressupostos o direito à saúde e à alimentação. A política tem como objetivo "a melhoria das condições de alimentação, nutrição e saúde da população brasileira, mediante a promoção de práticas alimentares adequadas e saudáveis, a vigilância alimentar e nutricional, a prevenção e o cuidado integral dos agravos relacionados à alimentação e nutrição" 21 .

\section{O Direito à Saúde}

O conceito de saúde é compreendido a partir de um elenco de saberes, que não se limitam à medicina, que vão além do conjunto das ciências médicas e que alcançam a sociologia, a antropologia, a filosofia e o direito. Mesmo que frequentemente seja abordada por oposição a noção de doença, saúde significa muito mais que a ausência de doença ou de acesso a medicamentos e insumos ou procedimentos terapêuticos.

Assim, saúde é um campo de interesse tanto às ciências duras quanto às ciências sociais. A epidemiologia contemporânea, por exemplo, não se limita ao estudo de fatores biológicos, microbiológicos, das doenças, mas investiga os fatores sociais da saúde das populações ${ }^{22}$ (p.7-17). A percepção social do que é saúde tem tamanha abrangência que opta, ao invés de dar um conceito de saúde, analisar "as possíveis representações no ambiente social"23 (p.44). Nesse sentido, saúde pode assumir uma significação positiva, como a ideia de bons hábitos de vida, de equilíbrio, de higiene, de consciência ecológica, de práticas de exercícios físicos, de alimentação saudável, etc.

Esta ainda é uma concepção individual da saúde, conforme definição adotada pela Organização Mundial de Saúde (OMS) ${ }^{24}$ :

Saúde é um estado de completo bem-estar físico, mental e social e não consiste apenas a ausência de doença ou de enfermidade. 
Foucault analisa o surgimento da medicina social, de forma a compreender a saúde pública como uma arena de embate social e tensão entre liberdade e igualdade. De fato, o Estado assumiu a tarefa de promover a saúde pública, mas esse processo histórico não foi pautado pelo ideal de um direito humano e sim a ideia de exercer um poder sobre a sociedade. E nesse sentido a medicina se construiu como uma estratégia bio-política, pois a partir do controle do corpo que se desenhou o controle da sociedade ${ }^{25}$ (p. 80-84).

E somente depois que o Estado já exercia o poder por meio da saúde pública que ocorreu o reconhecimento de um direito à saúde. $\mathrm{E}$, como direito, a saúde é um espaço de tensão entre liberdade e igualdade. Um exemplo foi o enfrentamento das epidemias, ora como a lepra, que excluía o doente do convívio social, ora no modelo da peste, que o internava em reclusão, a liberdade individual era limitada pelo interesse público mediado pelo poder estatal ${ }^{25}$ (p.8889).

Para Dallari ${ }^{26}$ (p.252) a moderna concepção de saúde pública remonta ao surgimento do Estado Moderno. Com o modelo do Welfare State, no século XX, firmou-se a saúde como responsabilidade estatal e atuação do Estado para defender a saúde pública, tornando-a politica de Estado.

\section{Breve Histórico do Direito à Saúde no Brasil}

Constituída como um direito fundamental, a saúde tem implicações diretas no bem-estar dos indivíduos, na integridade da sociedade e na produtividade da economia. Por esse motivo, se encontra agregada ao rol dos direitos humanos. Mas o amplo acesso à saúde só foi reconhecido constitucionalmente, como direito fundamental quando da promulgação da Constituição da Republica Federativa do Brasil de 1988, cujo processo constituinte, num espaço democrático, teve também alicerce em ideias de congressistas progressistas, amparados por intelectuais da Reforma Sanitária ${ }^{27}$ (p.12).

Ressalta-se que o tema saúde já constava nos textos constitucionais brasileiros anteriores a 1988, embora com sentido organizativo e administrativo:

É espantoso como um bem extraordinariamente relevante à vida humana só na Constituição de 1988 tenha sido elevado à condição de direito fundamental do homem. E há de informar-se pelo principio de que o direito à vida de todos os seres humanos significa também que, nos casos de doença, cada um tem o direito ao tratamento condigno de acordo com o estado atual da Ciência Médica, independente da sua situação econômica, sob pena de não ter mais valor sua consignação em normas constitucionais. O tema não era de todo estranho ao nosso direito constitucional anterior, que dava competência à União para legislar sobre defesa e 
proteção da saúde; mas isso tinha sentido de organização administrativa de combate ás endemias e epidemias. Agora é diferente, trata-se de direito do homem ${ }^{28}$ (p.188).

Assim, a Constituição de 1988 agregou no seu texto a saúde como direito fundamental, conferindo-lhe uma proteção jurídica especial, assegurando-a como direito de todos e dever do Estado, que deve ser garantida por política públicas, cabendo aos Poderes Executivo e Legislativo, mediante a elaboração de leis e a definição de prioridades e da escolha dos meios para sua realização ${ }^{29}(\mathrm{p} .9)$.

\section{Carta Magna de 1988: garantia da saúde como direito fundamental}

Os textos constitucionais anteriores à Constituição Federal de 1988 apenas determinavam aos entes federados a competência para legislar sobre saúde, sendo o direito à saúde reconhecido apenas para os trabalhadores com vínculo formal de trabalho. Restava aos excluídos dessa classe, a assistência caridosa prestada pelas entidades filantrópicas ${ }^{30}$ (p.102).

A saúde era apenas um benefício da Previdência Social e nessa perspectiva, as políticas públicas de promoção à saúde foram negligenciadas durante décadas. Esse cenário foi modificado pelo movimento da Reforma Sanitária entre o final dos anos 70 e início dos anos 80, em que setores da sociedade, técnicos, intelectuais, acadêmicos, partidos políticos e diversos movimentos sociais se mobilizaram ${ }^{31}$ (p.7).

Com a redemocratização, intensificou-se o debate nacional sobre a universalização dos serviços públicos de saúde. O momento culminante do "movimento sanitarista" foi a Assembleia Constituinte, em que se deu a criação do Sistema Único de Saúde. A Constituição Federal estabelece, no art. 196, que a saúde é "direito de todos e dever do Estado", além de instituir o "acesso universal e igualitário às ações e serviço para sua promoção, proteção e recuperação". A partir da Constituição Federal de 1988, a prestação de serviços público de saúde não mais estaria restrita aos trabalhadores inseridos no mercado formal. Todos os brasileiros, independentemente de vinculo empregatício, passaram a ser titulares do direito à saúde.

A Constituição Federal de 1988 assume a saúde como um direito social no art. $6^{\circ}$, estabelecendo nos artigos 196 a 201 uma estrutura politica complexa e abrangente para o sistema de saúde brasileiro, compreendendo a União, Estados e Municípios e o Distrito Federal $^{23}$, na elaboração, execução das politicas públicas de saúde. Assim:

Promover a saúde significa intervir socialmente na garantia nos direitos e nas estruturas econômicas que perpetuam as desigualdades na distribuição de bens e serviços. As politicas de saúde vêm no sentido de implementar estratégias

\footnotetext{
${ }^{23} \mathrm{O}$ art. 196 da $\mathrm{CF} / 88$ estabelece que a saúde é "um direito de todos e dever do Estado, garantido mediante politicas sociais e econômicas que visem à redução do risco de doença e outros agravos e ao acesso universal e igualitário às ações para sua promoção, proteção e recuperação". BRASIL. Constituição da Republica Federativa do Brasil. Brasília, DF: Senado Federal, 5 de outubro de 1988.
} 
governamentais que visam corrigir os desequilíbrios sociais e proporcionar a redução das desigualdades sociais ${ }^{32}$ (p.93).

A constitucionalização dos direitos fundamentais no Brasil representa a prerrogativa dos cidadãos de reivindicarem sua proteção ao Poder Judiciário, para concretização do principio democrático ${ }^{33,34}$. Por si só, tal prerrogativa não foi suficiente para garantia do acesso à saúde.

No que tange ao direito à saúde pode-se dizer que o desenvolvimento teórico acompanhou - partir de 1988, com atraso, portanto - caminho percorrido pela afirmação da teoria dos direitos fundamentais. O entendimento positivista-legalista, segundo o qual o direito é a regra posta pelo legislador, cedeu espaço para uma teoria jurídica em que as novas funções estatais constitucionalmente previstas passaram a ser reconhecidas como verdadeiras normas jurídicas aptas a provocar efeitos $\operatorname{concretos}^{30}$ (p.103).

Era preciso reconhecer que a saúde não devia apenas figurar como direito no papel, mas, acima de toda norma, ela devia ser efetivamente garantida. Para Dallari ${ }^{35}$ :

Fica evidente a dificuldade que existe para a garantia do direito quando se considera
a amplitude da significação do termo saúde e a complexidade do direito à saúde que
depende daquele frágil equilíbrio entre a liberdade e a igualdade, permeando pela
necessidade de reconhecimento do direito do Estado ao desenvolvimento. Encontrar
o meio de garantir efetivamente o direito à saúde é a tarefa que se impõe de modo
ineludível aos atuais constituintes brasileiros. Não basta apenas declarar que todos
têm direito à saúde; é indispensável que a Constituição organize os Poderes do
Estado e a vida social de forma a assegurar a cada pessoa o seu direito. É função de
todo profissional ligado à área da saúde contribuir para o debate sobre as formas
possíveis de organização social e estatal que possibilitem a garantia do direito à
saúde. [...] A nova Constituição do Brasil tratará certamente da saúde,
reconhecendo-a como um dos direitos fundamentais dos brasileiros. É indispensável,
porém, que ela preveja mecanismos para que nenhum dos direitos firmados seja
negado na prática constitucional.

Para efetivação do direito à saúde, a Constituição previu a implantação de um sistema público de saúde, de acesso universal e igualitário, regulamentado por legislação infraconstitucional. Assim, foi implantado o Sistema Único de Saúde (SUS) em que o Estado garante a efetividade do direito à saúde.

\section{A JUDICIALIZAÇÃO DAS POLITICAS PÚBLICAS}

Desde a publicação da Constituição Federal de 1988, particularmente no âmbito da jurisdição constitucional, tem sido comum a busca da sociedade pela efetivação dos direitos sociais. Assim, com a positivação dos direitos sociais nas normas jurídicas do Estado, esses direitos são introduzidos no sistema jurídico brasileiro.

Ao mesmo tempo em que se ampliaram os direitos sociais, por meio de lutas e conquistas, passou-se a exigir do Estado políticas para garantia desses direitos, seja por meio do Poder Legislativo ou do Poder Executivo. A sociedade busca a efetivação dos direitos sociais, e 
diante de um Executivo limitado pelos acordos macroeconômicos e políticos, demandam no Judiciário, reconhecendo-o efetivamente como uma das instituições do poder estatal, a possibilidade de efetivação destes direitos.

Percebe-se que o sistema jurídico é fundamentado na teoria pura do direito, com base no purismo metodológico e, desta forma encontra dificuldades para adotar a concepção de politicas públicas em suas operações internas ${ }^{36}$.

E as politicas públicas são redigidas de diversos modos, sem um padrão jurídico claro e definido. Para Bucci ${ }^{37}$, (p.262), “o modelo das politicas publicas, concebido como forma de implementação do Estado de Bem-Estar, pairou acima ou ao lado das estruturas jurídicas tradicionais, não sido integrado ao ordenamento jurídico". O que causa dificuldades para um sistema "puro" informado apenas pelo próprio direito.

Faria $^{38}$ (p.94) relata que os direitos sociais vêm complicando a aplicação da lei. Verifica-se que o Judiciário "força" a proteção dos direitos sociais aos mesmos moldes dos direitos individuais. Tratam igualmente direitos que por essência, demandam tratamentos diferentes e dependem de estímulos políticos diferentes.

E assim, verifica-se que as decisões judiciais não são capazes de resolver os problemas jurídicos que perpassam em torno da efetivação e garantia dos direitos sociais. O termo judicialização da política tem servido para indicar "os efeitos da expansão do Poder Judiciário no processo decisório das democracias contemporâneas" ${ }^{39}$ (p. 114).

\section{A Judicialização do Direito à Alimentação}

O direito à alimentação está inserido nos extensos limites abrangente da assistência social e ainda não adquiriu título específico, diferentemente dos direitos à saúde, educação e cultura.

Verifica-se que os processos que solicitam alimentos ao Estado é mais uma modalidade de processo constitucional judicial, pois, sob a atuação do Poder Judiciário, este caracteriza um conjunto de atos mediante os quais o órgão jurisdicional atua conforme a vontade das normas constitucionais ${ }^{40}$ (p.9).

A partir da perspectiva da jurisdição constitucional $^{24}$, é possível prever que muitos instrumentos processuais estão à disposição dos indivíduos que solicitam algum tipo de

\footnotetext{
${ }^{24}$ Em sentido estrito, jurisdição constitucional consiste na entrega aos órgãos do poder judiciário, da missão de solucionar os conflitos entre as normas jurídicas ordinárias (e complementares) e a constituição. E, mais
} 
alimento ao Estado. A existência desse fundamento constitucional suscita a ideia de processo constitucional, que, incorpora a ação civil pública, a ação popular e o mandado de segurança como possibilidades de controle judicial das políticas relacionadas ao direito à alimentação.

As ações ordinárias de conhecimento, além das ações cautelares e das tutelas de emergência, são instrumentos que possuem capacidade jurídica para os indivíduos que solicitam alimentos ao Estado junto aos Tribunais, além de chamar a atenção para o uso desses alimentos em indivíduos com algum agravo de saúde. Atualmente as ações judiciais é a principal forma de judicializar o direito à alimentação.

O Estado, na figura da União, Estados, Distrito Federal e Municípios, possuem a responsabilidade constitucional de garantir os direitos sociais. É de competência comum dos entes federados o cuidado com a assistência pública (a qual inclui a alimentação), a organização de politicas de abastecimento alimentar e o enfrentamento das causas da pobreza e dos fatores de marginalização. Tais responsabilidades devem ser solidária ${ }^{41}$ (p.181).

No Brasil, verifica-se que às politicas públicas de alimentação são, na sua maioria, coordenadas e executadas pelo Poder Executivo Federal e pouco se noticia sobre iniciativas estaduais ou municipais, principalmente quando se olha para fora das grandes capitais. Assim, ainda há muito que descentralizar para concretizar a vontade constitucional, pois os quatro entes federados são competentes e responsáveis pelo direito à alimentação ${ }^{42}$.

A judicialização do direito à alimentação é a tendência que já se torna realidade. Apesar de estar sendo apresentada por meio de discussões pautadas nas leis infraconstitucionais, trata-se apenas de esperar o tempo de amadurecimento necessário para que seja possível conceber que, na realidade, requisitos burocráticos não foram impostos pela Constituição do Brasil para que o cidadão tenha direito à alimentação ${ }^{42}$.

\section{A Judicialização da Saúde}

O fenômeno da judicialização da saúde no Brasil é um dos temas vigentes nos debates envolvendo as instituições de ensino superior, operadores do direito, o governo e a própria sociedade civil.

amplamente (sentido próprio), é a entrega ao poder judiciário da missão de solucionar conflitos constitucionais. SILVA, José Afonso. Jurisdição Constitucional da Liberdade no Brasil. Revista do Centro de Estúdios Políticos y Constitucionales, p. 9. Disponível em: http://www.cepc.es/rap/Publicaciones/Revistas/8/AIB_003_009.pdf (acesso em 08 de março de 2016). 
No Brasil, a Constituição Federal de 1988 ao classificar a saúde como um direito social e garantir a integralidade do acesso para todos os cidadãos não projetou colocar em confronto os poderes republicanos, independentes e autônomos entre si, nem instigar o Poder Judiciário e determinar o Executivo como este deva gastar os recursos em saúde.

A Constituição de 1988 pretendeu permitir a todos os brasileiros acesso aos serviços de saúde, erro reparado com o disposto no artigo $6^{\circ}$ aliado com o artigo 196 que garantiu o acesso universal e igualitário. O artigo 196, estabelece que a saúde é "direito de todos e dever do Estado". Institui também o "acesso universal e igualitário às ações e serviços para sua promoção, proteção e recuperação". O artigo 198 complementa que a atenção integral terá prioridade as atividades preventivas, sem prejuízo dos serviços assistenciais.

Assim, as politicas públicas de saúde passaram a ser orientadas pelos princípios da universalidade equidade do acesso às ações e serviços e pelas normas de descentralização da gestão, da integralidade da atenção e da participação da comunidade.

Para Silva ${ }^{43}$,

\begin{abstract}
A saúde é concebida como direito de todos e dever do Estado, que a deve garantir mediante políticas sociais e econômicas que visem à redução do risco de doença e de outros agravos. O direito a saúde rege-se pelo princípio da universalidade e da igualdade de acesso às ações e serviços que a promovem, protegem e recuperem. $\mathrm{O}$ SUS, integrado de uma rede regionalizada e hierarquizada de ações e serviços da saúde, constitui o meio pelo qual o Poder Público cumpre seu dever na relação jurídica de saúde que tem no polo ativo qualquer pessoa e comunidade, já que o direito à promoção e à proteção da saúde é também um direito coletivo (p.402).
\end{abstract}

O caminho do Judiciário para garantia do acesso aos medicamentos se iniciou na década de 90, com as demandas para medicamentos antirretrovirais. E a participação de vários atores da sociedade civil organizada juntamente com as agências de cooperação internacional junto ao poder publico. Esse movimento resultou em políticas publicas de proteção ao direito à saúde dos indivíduos com HIV/AIDS ${ }^{44}$ (p.109).

A saúde dispõe de características que lhe concedem contornos de direitos subjetivo público. Possibilitando que cidadãos entrem com uma ação junto ao Poder Judiciário para exigir do Estado a adoção ou rejeição de medidas concretas em favor da saúde. Assim, o cidadão se reconhece como sujeito desse direito e busca efetivá-lo por meio de processo junto ao Judiciário $^{44}$ (p.111).

O fenômeno da judicialização da saúde também pode ser visto como um problema, pois abarrotam os tribunais com demandas e comprometem parte significativa dos orçamentos da 
saúde $^{45}$. Uma das grandes críticas a esse fenômeno no Brasil é que o mesmo tem sido reduzido apenas ao fornecimento de medicamento pelo poder público aos cidadãos. Mas há outras demandas judiciais para efetivação do direito a procedimentos cirúrgicos, transplantes, vagas em hospitais, leitos em UTI, alimentos, entre outros. Todavia, a grande demanda está restrita à solicitação de medicamentos ${ }^{46}$.

Os fundamentos e alternativas legais para que o cidadão proponha ações judiciais com o objetivo de obter medicamentos e outros serviços de saúde permitem uma reflexão desse fenômeno. Marques ${ }^{47}$ (2005) aponta que grande parte dos que procuram o Poder Judiciário, o fazem individualmente, e os pedidos estão sendo deferidos pelos magistrados com fundamento, apenas, na prescrição médica.

Além disso, a prescrição médica vem sendo problematizada em vários estudos ${ }^{48,49,50}$ em que destacam a influência da indústria farmacêutica nas prescrições e o poderio médico.

Para Pepe $^{46}$ (2010) as ações judiciais ajuizadas para garantir direitos do cidadão como “judicialização" é desqualificar a atuação judicial, pressupondo que o Poder Judiciário está interferindo indevidamente na atuação do Poder Executivo. Nessa perspectiva, observa-se que é há um processo de judicialização excessiva, que se demonstrada pelo aumento de decisões que condenam o Poder Público ao pagamento de tratamentos ainda sem comprovação científica e transfere ao gestor local a responsabilidade da decisão de aplicação de recursos que, muitas das vezes, contradiz o princípio da equidade em saúde e o acesso à assistência à saúde de qualidade.

Barroso $^{51}$ (2011) estabelece que:

Em muitos casos, o que se revela é a concessão de privilégios a alguns jurisdicionados em detrimento da generalidade da cidadania, que continua dependente das políticas universalistas implementadas pelo Poder Executivo ${ }^{51(p .4)}$

Ressalta-se que apesar da importância do Pode Judiciário como guardião da Constituição e dos direitos fundamentais, ele não pode induzir à "absolutização do direito à saúde", desorganizando o sistema, resultando na provocação ao principio da isonomia, haja vista se tratar de um direito misto: é fundamental originário, vez que garantido pela $\mathrm{CF} / 88$, mas é também derivado, que disciplinado por legislação infraconstitucional. Sem dúvida, percebe-se que a judicialização excessiva do acesso à saúde compromete a universalização da saúde ${ }^{52}$. 


\section{REFERÊNCIAS}

1. Bobbio N. A era dos direitos. Tradução: Coutinho CN. Nova ed. — Rio de Janeiro: Elsevier, 2004. $7^{\mathrm{a}}$ reimpressão.

2. Araújo LAD, Nunes Júnior VD. Curso de Direito Constitucional. Imprenta: São Paulo, Saraiva, 2001. $448 \mathrm{p}$.

3. Oliveira MD. Direito Fundamental à Saúde e suas faces: uma análise conjunta à irretroatividade do direito fundamental social à saúde. In: Gottems CJ, Siqueira DP (Coord.). Direitos Fundamentais da Normatização à efetividade nos 20 anos da Constituição Brasileira. Birigui, SP: Boreal Editora, 2008. P. 2010-220.

4. Coelho LF. A Fundamentação do Direitos Humanos. In: Klock AB, Cambi E, Alves, FB (Orgs). Direitos Fundamentais revisitados. Curitiba: Juruá editora, 2008. p. 39-88.

5. Comparato, FK. A afirmação historica dos direitos humanos. 7. Ed. São Paulo: saraiva, 2010.

6. Gomes SA. Hermenêutica Constitucional: um contributo à construção do estado democrático de direito. Curitiba: Juruá, 2008.

7. Pinho RCR. Teoria geral da constituição e direitos fundamentai /Rodrigo César Rebello Pinho. - 11. ed. - São Paulo: Saraiva, 2011. (Coleção sinopses jurídicas; v. 17).

8. Netto LCP. O principio de proibição de retrocesso social. Porto Alegre: Livraria do Advogado Editora, 2010.

9. Iurconvite AS. A evolução histórica dos direitos sociais: da Constituição do Império à Constituição Cidadã. In: Âmbito Jurídico, Rio Grande, XIII, n. 74, mar 2010. Disponível em: <http://www.ambito juridico.com.br/site/index.php?n_link=revista_artigos_leitura\&artigo_id=7417>. Acesso em mar 2016.

10. Moraes, A. Direito Constitucional. $26^{\mathrm{a}}$ ed. São Paulo: Atlas, 2010.

11. Organização das Nações Unidas. Declaração dos Direitos Humanos, 1948.

12. Brasil. Decreto $\mathrm{n}^{\circ}$ 591, de 6 de julho de 1992. Atos Internacionais. Pacto Internacional sobre Direitos Econômicos, Sociais e Culturais. Diário Oficial da União, Seção 1, n 128 , p. 8713-8716, 7 de julho de 1992.

13. Maniglia E. As interfaces do direito agrário e dos direitos humanos e a segurança alimentar. São Paulo:Cultura Acadêmica, 2009. p. 125.

14. Brasil. Constituição da República Federativa do Brasil: Texto constitucional promulgado em 5 de outubro de 1988, com as alterações adotadas pelas Emendas Constitucionais n ${ }^{\circ}$ 1/92 a 71/2012 e pelas Emendas Constitucionais de Revisão $n^{\circ} 1$ a 6/94. - Brasília: Senado Federal, Subsecretaria de Edições Técnicas, 2013, 87p. 2013.

15. Leão $\mathrm{M}$. O direito humano à alimentação adequada e o sistema nacional de segurança alimentar e nutricional / organizadora, Leão M. - Brasília: ABRANDH, 2013. 263 p.

16. Brasil. Lei $\mathrm{n}^{\circ} 11.346$ de 15 de setembro de 2006. Cria o Sistema Nacional de Segurança Alimentar e Nutricional - SISAN com vistas em assegurar o direito humano à alimentação adequada e dá outras providências. Diário Oficial da União, Seção 1, nº 179, p. 1-2, 18 de setembro de 2006.

17. Estorninho MJ (coord.). Estudos de Direito da Alimentação. Instituto de Ciências Jurídico-Políticas. Universidade de Lisboa. Faculdade de Direito. 2013. 
18. Silva JA. Curso de Direito Constitucional Positivo. 23. ed. São Paulo: Malheiros, 2004.

19. Dallari DA. Elementos de Teoria Geral do Estado. 16. ed. São Paulo: Saraiva, 1991.

20. Silva JF. Aplicabilidade das Normas Constitucionais. 3. ed. São Paulo: Malheiros, 1999.

21. Brasil. Ministério da Saúde. Secretaria de Atenção à Saúde. Departamento de Atenção Básica. Política Nacional de Alimentação e Nutrição/Ministério da Saúde. Secretaria de Atenção à Saúde. Departamento de Atenção Básica. - Brasília: Ministério da Saúde, 2012. 84 p.: il. - (Série B. Textos Básicos de Saúde).

22. Barata RB. Epidemiologia Social. Revista Brasileira de Epidemiologia, v.8, n.1, São Paulo, mar.2005, p.7-17.

23. Aith F. Curso de Direito Sanitário: a proteção do Direito à Saúde no Brasil. São Paulo: Quartier Latin, 2007.

24. Organização Mundial da Saúde (OMS). Carta da Organização Mundial de Saúde, 1946. Disponível em: <http://www.onuportugal.pt/oms.doc>. Acesso em: 28 fev. 2016.

25. Foucoult M. Microfisica do Poder. Rio de Janeiro: Graal, 1979.

26. Dallari DA. Elementos de Teoria Geral do Estado. Saraiva: São Paulo, 2006.

27. Brasil. Conselho Nacional de Secretários de Saúde. Legislação Estruturante do SUS. Brasilia: CONASS, 2007. (Coleção Progestores-Para entender a gestão do SUS, 12).

28. Silva JA. Comentário Constextual à Constituição.7ed. São Paulo: Malheiros, 2010.

29. Delduque MC, Oliveira MSC. O papel do Ministério publico no campo do Direito e Saude. In: Brasil. Mnisterio da Saude. Fundação Osvaldo Cruz. Questões atuais do direito sanitário, 2006. (Serie Legislação de Saúde).

30. Mânica FB. O setor privado nos serviços públicos de saúde. Belo Horizonte: Fórum, 2010.

31. Brasil. Ministério da Saude. Secretaria de Gestão Estratégica e Participativa. Departamento de Apoio à Gestão Participativa. Caminhos do Direito à Saúde no Brasil. Brasilia. Ministério da Saúde, 2007. (Série B. Textos Básicos de Saúde).

32. Pessini L, Barchifontaine CP. Problemas Atuais de Bioeéica. 6. Ed. São Paulo:Loyola, 2002.

33. Moraes A. Direitos humanos fundamentais: teoria geral, comentários aos arts. $1^{\circ}$ ao $5^{\circ}$ da Constituição da República Federativa do Brasil, doutrina e jurisprudência. 7 ed. São Paulo: Atlas, 2006.

34. Piovesan F. Direitos humanos e o direito Constitucional Internacional. 6 ed. São Paulo: Max Limonad,2004.

35. Dallari SG. O Direito à Saúde. Revista de saúde Publica, São Paulo 22 (1):57-63, 1988.

36. Marques SB. Judiacialização do Direito à Saúde. Revista de Direito Sanitário, São Paulo v. 9, n. 2 p. 65 72 Jul./Out. 2008.

37. Bucci MPD. Direito administrativo e políticas públicas. São Paulo: Saraiva; 2002.

38. Faria JE. O Judiciario e os direitos humanos e sociais: nota para uma avaliação da justiça brasileira. In: Faria JE (org.) Direito e Justiça. Direitos humanos, direitos sociais e justiça. $3^{\text {a }}$ tiragem: Malheiros; 2002.

39. Maciel D, Koerner A. Sentidos da judicialização da política: duas análises. Lua Nova 2002; 57:113-133. 
40. Dimoulis D, Lunardi S. Curso de Processo Constitucional: controle de constitucionalidade e remédios constitucionais. São Paulo: Atlas, 2011.p. 9.

41. Burity V, Franceschini T, Recine FVE, Leão M, Carvalho MF. Direito humano à alimentação adequada no contexto da segurança alimentar e nutricional / Burity, V. [et al.]. - Brasília, DF: ABRANDH, 2010. $204 p$.

42. Lira, JA. A Concretização e a Judicialização do Direito Constitucional à Alimentação no Brasil. Escola da Magistratura do Estado do Rio de Janeiro. [Pós-Graduação]. Rio de Janeiro, 2013.

43. Silva JA. Curso de Direito Constitucional Positivo. Imprenta: São Paulo, Malheiros, 2006. 924 p.

44. Terrazas FV. Novos elementos no cenário da judicialização da saúde: análise das decisões dos Tribunais Superiores. In: Santos L, Terrazas FV. (Org.). Judicialização da Saúde no Brasil. 1ed.Campinas: Saberes Editora, 2014, v., p. 307-330.

45. Barroso LR. Curso de direito constitucional contemporâneo: os conceitos fundamentais e a construção do novo modelo. 2. ed. São Paulo: Saraiva, 2010. xxii, 453 p.

46. Pepe VLE, Ventura M, Figueiredo TA, Souza VR, Simas L, Osovio-de-Castro CGS. Caracterização de demandas judiciais de fornecimento de medicamentos "essenciais" no Estado do Rio de Janeiro, Brasil. Cad. Saúde Pública, Rio de Janeiro, 26(3):461-471, mar, 2010.

47. Marques SB. A relação do sistema jurídico e do sistema político na garantia do direito social à assistência farmacêutica: o caso do Estado e São Paulo. Universidade de São Paulo. Faculdade de Saúde Pública. [Dissertação]. São Paulo, 2005.

48. Barros JAC. Politicas Farmacêuticas: A serviço dos interesses da saúde? Brasilia, UNESCO, 2004.

49. Barros JAC, Joany S. Anúncios em medicamentos em revistas medicas: ajudando a promover a boa prescrição? Ciencia e Saúde Coletiva, 7(4):891-898; 2002.

50. Brasil. Ministério da Saúde. Estudo Comparados: Regulamentação da `Propaganda de Medicamentos. Série E. Legistação da Saúde. Brasilia: Ministerio da Saúde, 2005.

51. Barroso LR. Curso de Direito Constitucional Contemporâneo: os conceitos fundamentais e a construção do novo modelo. 3. ed. São Paulo: Saraiva, 2011. 505 p.

52. Pscheidt KR. Agência Nacional de Saúde Suplementar: o Estado e a Saúde Privada no Brasil. Curitiba Edição do Autor. Brasil, 2104.90p. 


\title{
APÊNDICE B - ROTEIRO SEMIESTRUTURADO PARA ENTREVISTAS
}

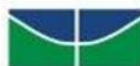 \\ Universidade de Brasilia \\ Faculdade de Ciências da Saúde \\ Programa de Pós - Graduação em Saúde Coletiva
}

\section{Roteiro para entrevistas semi estruturado}

- A alimentação é um direito garantido a todos brasileiros na Constituição. Quais as responsabilidades do poder público para garantia desse direito?

- Algumas pessoas possuem necessidades alimentares especiais e precisam utilizar fórmulas nutricionais industrializadas para alimentação. A judicialização do SUS para acesso a essas formula tem se tornado crescente. O senhor recebe esse tipo de demanda no seu trabalho? Como realiza a análise para tomada de decisão desses casos?

- O que o senhor identifica como possíveis causas da judicialização para acesso às fórmulas nutricionais?

- O que o senhor sugere para resolução desse problemas? 


\title{
APÊNDICE C- TERMO DE CONSENTIMENTO LIVRE E ESCLARECIDO
}

\author{
Y \\ Universidade de Brasilia \\ Faculdade de Ciências da Saúde \\ Programa de Pós - Graduação em Saúde Coletiva
}

\section{Termo de Consentimento Livre e Esclarecido - TCLE}

Convidamos o(a) Senhor(a) a participar do projeto de pesquisa Acesso às fórmulas nutricionais para usuários do SUS: percepções do poder judiciário frente ao crescimento da judicialização, sob a responsabilidade do pesquisador Kimielle Cristina Silva. O projeto propõe a análise das percepções do Poder Judiciário sobre o crescimento da judicialização pelo acesso às fórmulas nutricionais no SUS. Considerando que as discussões nesta temática são ainda incipientes na literatura e que se trata de demanda da instituição a qual o pesquisador está vinculado, onde desenvolve atividades relacionadas ao monitoramento e avaliação dessas demandas judiciais no âmbito da União.

O objetivo desta pesquisa é conhecer e analisar as percepções de atores do Poder Judiciário sobre a judicialização pelo acesso às formulas nutricionais no Sistema Único de Saúde - SUS.

$\mathrm{O}$ (a) senhor(a) receberá todos os esclarecimentos necessários antes e no decorrer da pesquisa e lhe asseguramos que seu nome não aparecerá sendo mantido o mais rigoroso sigilo pela omissão total de quaisquer informações que permitam identificá-lo(a)

A sua participação nessa pesquisa se dará por meio do procedimento chamado "entrevista semiestruturada", no qual o pesquisador terá um roteiro preliminar com perguntas sobre o tema do estudo e o entrevistado tem a possibilidade de falar sobre o tema em questão sem se prender à pergunta formulada. Ou seja, novas perguntas poderão ser incluídas quando for percebido que temas considerados importantes, que não estiveram presentes no roteiro inicial, aparecerem na discussão. Essa entrevista será registrada em áudio, através de um gravador digital. Todos os diálogos serão transcritos e utilizados como dados para a pesquisa. entrevista semiestruturada em seu local de trabalho, ou outro de sua preferência na data combinada com um tempo estimado de cerca de 30 minutos para sua realização.

Se você aceitar participar, estará contribuindo para organização do acesso ás fórmulas nutricionais do âmbito do SUS.

$\mathrm{O}$ (a) Senhor(a) pode se recusar a responder (ou participar de qualquer procedimento) qualquer questão que lhe traga constrangimento, podendo desistir de participar da pesquisa em qualquer momento sem nenhum prejuízo para o(a) senhor(a). Sua participação é voluntária, isto é, não há pagamento por sua colaboração.

Todas as despesas que você tiver relacionadas diretamente ao projeto de pesquisa (passagem para o local da pesquisa, alimentação no local da pesquisa ou exames para realização da pesquisa) serão cobertas pelo pesquisador responsável. 
Caso haja algum dano direto ou indireto resultante dos procedimentos de pesquisa, você poderá ser indenizado, obedecendo-se as disposições legais vigentes no Brasil.

Os resultados da pesquisa serão divulgados na Universidade de Brasília -UnB podendo ser publicados posteriormente. Os dados e materiais utilizados na pesquisa ficarão sob a guarda do pesquisador por um período de no mínimo cinco anos, após isso serão destruídos ou mantidos na instituição.

Se o(a) Senhor(a) tiver qualquer dúvida em relação à pesquisa, por favor telefone para Kimielle Cristina Silva, na UnB no telefone 61-8334-8002.

Este projeto foi Aprovado pelo Comitê de Ética em Pesquisa da Faculdade de Ciências da Saúde (CEP/FS) da Universidade de Brasília. O CEP é composto por profissionais de diferentes áreas cuja função é defender os interesses dos participantes da pesquisa em sua integridade e dignidade e contribuir no desenvolvimento da pesquisa dentro de padrões éticos. As dúvidas com relação à assinatura do TCLE ou os direitos do participante da pesquisa podem ser obtidos através do telefone: (61) 3107-1947 ou do e-mail cepfs@unb.brou cepfsunb@gmail.com, horário de atendimento de 10hs às 12hs e de 14hs às 17hs, de segunda a sexta-feira.

Este documento foi elaborado em duas vias, uma ficará com o pesquisador responsável e a outra com o Senhor(a).

Nome / assinatura

Pesquisador Responsável

Nome e assinatura

Brasília, de de 


\section{APÊNDICE D- PARECER CONSUBSTANCIADO DO COMITÊ DE ÉTICA E PESQUISA}

FACULDADE DE CIÊNCIAS DA
SAÚDE DA UNIVERSIDADE DE Platoforma
BRASÍLIA - CEP/FS-UNB

\section{DADOS DO PROJETO DE PESQUISA}

Título da Pesquisa: Acesso às fórmulas nutricionais para usuários do SUS: percepções do poder judiciário frente ao crescimento da judicialização.

Pesquisador: Kimielle Cristina Silva

Área Temática:

Versão: 2

CAAE: 37891714.0 .0000 .0030

Instituição Proponente: FACULDADE DE SAÚDE - FS

Patrocinador Principal: Financiamento Próprio

\section{DADOS DO PARECER}

Número do Parecer: 1.014.733

Data da Relatoria: 08/04/2015

Apresentação do Projeto:

As demandas judiciais relacionadas a procedimentos e insumos de saúde contra entes públicos no Brasil cresceu exponencialmente nos últimos anos. Este fenômeno, denominado judicialização da saúde, envolve aspectos políticos, sociais, éticos e sanitários, que vão além do componente jurídico e de gestão de serviços públicos, trazendo alterações significativas nas relações sociais e institucionais (VENTURA, 2010).Como a saúde e a alimentação são consideradas direitos pela Constituição Federal, a solicitação de fórmulas nutricionais por meio de ações judiciais contra as três esferas de gestão do SUS tem crescido, constituindose como um problema para o Poder Público. A necessidade de financiamento e a elaboração de protocolos são demandas recorrentes em diversos espaços de pactuação e congressos regionais e nacionais que contam com a presença dos gestores. Existem diversos estudos que discutem a judicialização da saúde e verificam o perfil das demandas, porém, não há publicações de abrangência nacional cujo tema tenha sido a solicitação de fórmulas nutricionais ao Estado.Diante deste contexto, este projeto de pesquisa propõe a análise das percepções do Poder Judiciário sobre o crescimento da judicialização pelo acesso às fórmulas nutricionais no SUS. Considerando que as discussões nesta temática são ainda incipientes na literatura e que se trata de demanda da instituição a qual o pesquisador está vinculado, onde desenvolve atividades relacionadas ao monitoramento e avaliação dessas

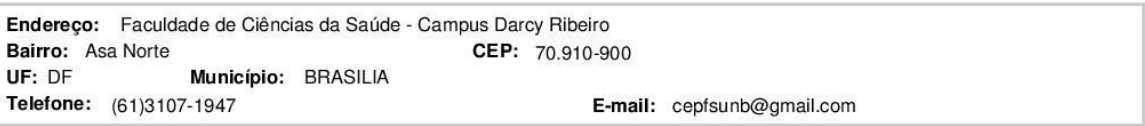




FACULDADE DE CIÊNCIAS DA
SAÚDE DA UNIVERSIDADE DE Platoforma
BnB BíliA - CEP/FS-UNB

Continuação do Parecer: 1.014 .733

demandas judiciais no âmbito da União. Será realizada pesquisa exploratória, adotada a abordagem qualitativa. Para coleta de dados juntos aos participantes será utilizada a técnica de entrevista semiestruturada. Este tipo de instrumento permite que o entrevistado tenha a possibilidade de discorrer sobre o tema em questão sem se prender a questão formulada, ao mesmo tempo em que possibilita ao entrevistador fazer novas indagações ao entrevistado a partir das suas reflexões durante a entrevista. $O$ roteiro da entrevista semiestruturada será construído com base nos objetivos específicos desse estudo. A escolha dos sujeitos para esta pesquisa se dará a partir da identificação de informantes-chave, ou seja, aqueles que possuam experiências, informações e percepções sobre o tema do estudo em suas diferentes dimensões. Desta forma, serão sujeitos deste estudo os representantes da tríade processual no Poder Judiciário:

2 Autores (aquele que promove a ação judicial representados pela Defensoria Pública)

2 Réus (aquele que sofre a ação do autor representado pelo Advogado da União

2 Juízes (aquele que decide o conflito entre o autor e o réu)

Fez-se uma opção metodológica em privilegiar os representantes do autor e do réu em virtude da dificuldade em obter das pessoas físicas dos pacientes (autores das ações), respostas sobre a percepção sobre a judicialização pelo acesso às fórmulas nutricionais, preferindo-se nesses casos entrevistar o Defensor Público proponente da respectiva ação, melhor versado no tema. Do mesmo modo, o réu nas ações, identificado como o Ministério da Saúde, tornar-se-ia inexequível a pesquisa, vez que haveria de identificarse um destinatário para a obtenção das percepções sobre a Judicialização. Tendo como entrevistado a Advocacia da União, que faz, obrigatoriamente, a defesa do Ministério nas ações em que participa, tornar-se -ão mais evidentes os aspectos a serem analisados neste trabalho.

Objetivo da Pesquisa:

Objetivo Primário:

Conhecer e analisar as percepções de atores do Poder Judiciário sobre a judicialização pelo acesso às formulas nutricionais no Sistema Único de Saúde - SUS Objetivo Secundário:

- Identificar atores da tríade processual (Autores, Réus e Juízes), no âmbito da União que estejam relacionados à judicialização da saúde;

- Conhecer as percepções dos atores da tríade processual (Autores, Réus e Juízes) no âmbito da União que estejam relacionados à judicialização da saúde, por intermédio de seus representantes na ação judicial;

- Analisar as percepções desses diferentes atores, buscando identificar as diferenças, convergências e divergências acerca da judicialização pelo acesso às fórmulas nutricionais no SUS.

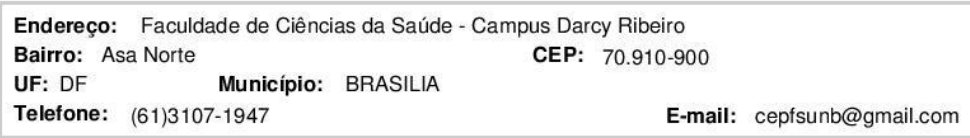




FACULDADE DE CIÊNCIAS DA
SAÚDE DA UNIVERSIDADE DE Platoforma
BnB
BnASILIA - CEP/FS-UNB

Continuação do Parecer: 1.014 .733

Avaliação dos Riscos e Benefícios:

Nas palavras da pesquisadora:

"Riscos:

Risco de constrangimentos

Benefícios:

A partir da percepção dos diferentes atores envolvidos neste processo, analisar a cadeia de eventos e recomendações para a organização do acesso ás fórmulas nutricionais do âmbito do SUS."

\section{Comentários e Considerações sobre a Pesquisa:}

Trata-se de projeto de mestrado do programa de Pós-Graduação em Saúde Coletiva. Encontra-se redigido de maneira clara e possui itens necessários para a análise. Na metodologia, solicita-se definir como serão recrutados esses participantes (não há informações de como serão encontrados Juízes, Réus e Atores desses processos, onde serão abordados, quem fará o convite), como serão registradas as entrevistas (serão gravadas e transcritas. Acrescentar termo para utilização de imagem e voz), em que local as entrevistas acontecerão (assegurar a privacidade é fundamental).

\section{Considerações sobre os Termos de apresentação obrigatória:}

Foram apresentados:

Informações Básicas do Projeto - "PB_INFORMAÇÕES_BÁSICAS_DO_PROJETO_403913.pdf", postado em 13/03/2015;

"RoteiroSemiestruturado_final.pdf", postado em 10/12/2014;

TCLE - elaborado com todas as informações e linguagem acessível - "ModTCLE 08.2014_Kimielle_final.pdf", postado em 28/10/2014;

Projeto Detalhado - "Projeto_para_comite_final_28_10.pdf", postado em 28/10/2014;

Folha de Rosto corretamente preenchida e assinada pela Profa. Maria Fátima Sousa, diretora da FS - "Folha de rosto_Kimielle.pdf", postado em 23/10/2014;

"TermoAutorizImagemSom_Kimielle.pdf", postado em 10/12/2014;

"Currículo do Sistema de Currículos Lattes (Maria Célia Delduque Nogueira Pires de Sá).pdf", postado em 10/12/2014;

"Kimielle_CV.pdf", postado em 10/12/2014;

"Termo_pesquisador.pdf", postado em 29/10/2014;

"Apresentaçãoprojeto.pdf", postado em 29/10/2014;

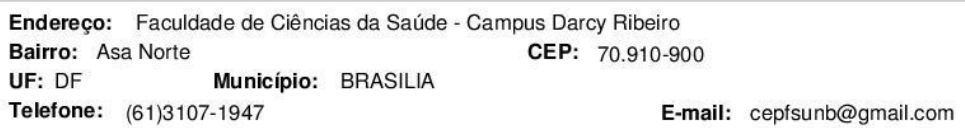




FACULDADE DE CIÊNCIAS DA
SAÚDE DA UNIVERSIDADE DE Platoforma
BnB
BnASILIA - CEP/FS-UNB

Continuação do Parecer: 1.014.733

Termo de concordância da instituição coparticipante assinado pela Profa. Maria Fátima Sousa, diretora da FS - "termodeconcordancia_final.pdf", postado em 29/10/2014;

"Encaminhamento_pesquisa.pdf", postado em 24/10/2014;

Termo de responsabilidade do pesquisador responsável - "Termo_pesquisador.pdf", postado em 24/10/2014.

\section{Recomendações:}

Não se aplica.

Conclusões ou Pendências e Lista de Inadequações:

Análise das respostas às pendências apontadas no parecer No. 893.828 de 25/11/2014:

Solicita-se as seguintes alterações:

1) Inserir currículos dos pesquisadores envolvidos. PENDÊNCIA ATENDIDA

2) Na metodologia: definir como serão recrutados esses participantes (como serão encontrados Juízes, Réus e Atores desses processos, onde serão abordados, quem fará o convite), como serão registradas e analisadas as entrevistas (serão gravadas e transcritas, como descrito no TCLE), em que local as entrevistas acontecerão (assegurar a privacidade é fundamental, no TCLE está descrito, na metodologia não).RESPOSTA DA PESQUISADORA: "Recrutamento dos participantes se dará por meio convite a ser enviado nominalmente por correio eletrônico. A escolha dos participantes será pela lista de contatos de representantes do Poder Judiciário da Coordenação de Direito Sanitário da FioCruz/Brasilia. As entrevistas serão realizadas em local a ser combinado com o informante ou por telefone." PENDÊNCIA ATENDIDA.

3) Apresentar termo de autorização para utilização de imagem e som de voz para fins de pesquisa, caso as entrevistas sejam gravadas. PENDÊNCIA ATENDIDA

4) Apresentar roteiro semi-estruturado para entrevista para análise ética. PENDÊNCIA ATENDIDA.

\section{Situação do Parecer:}

Aprovado

Necessita Apreciação da CONEP:

Não

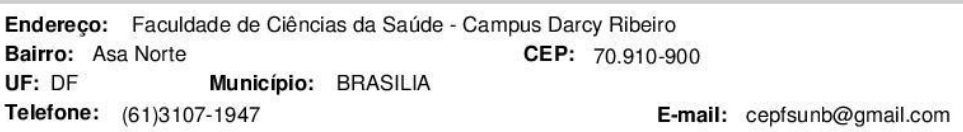




FACULDADE DE CIÊNCIAS DA
SAÚDE DA UNIVERSIDADE DE Platoforma
BnB
BnASILIA - CEP/FS-UNB

Continuação do Parecer: 1.014.733

Considerações Finais a critério do CEP:

Em acordo com a Resolução 466/12 CNS, ítens X.1.- 3.b. e XI.2.d, os pesquisadores responsáveis deverão apresentar relatórios parcial semestral e final do projeto de pesquisa, contados a partir da data de aprovação do protocolo de pesquisa.

BRASILIA, 08 de Abril de 2015

Assinado por:

Marie Togashi

(Coordenador)

Endereço: Faculdade de Ciências da Saúde - Campus Darcy Ribeiro

Bairro: Asa Norte CEP: $70.910-900$

UF: DF Município: BRASILIA

Telefone: (61)3107-1947

E-mail: cepfsunb@gmail.com

Página 05 de 05 


\section{APÊNDICE E- RESUMOS E IDEIAS: PERGUNTA № 1}

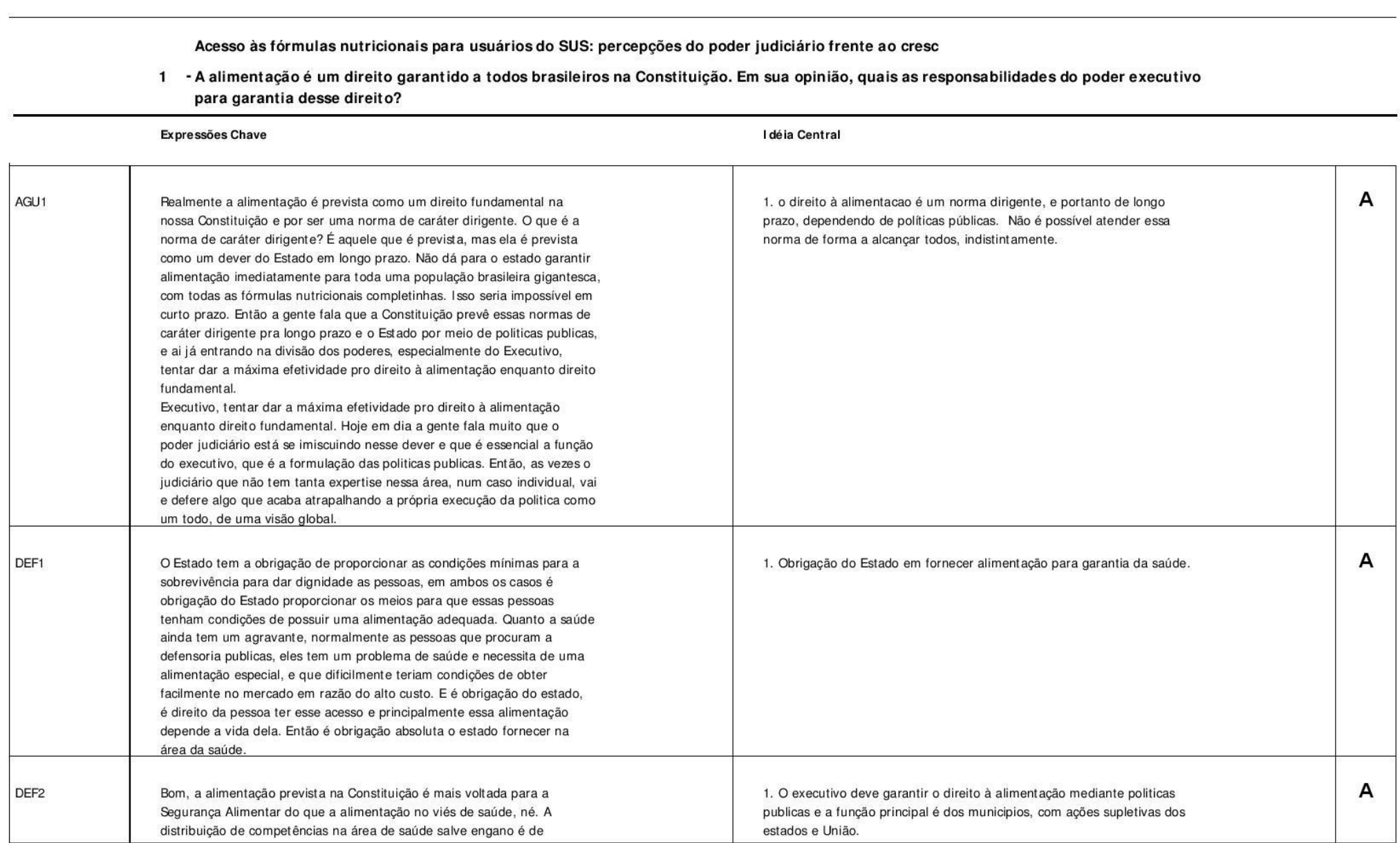


QualiQuantiSoft巴 .

Maria Célia Delduque Nogueira Pires de Sá

Acesso às fórmulas nutricionais para usuários do SUS: percepções do poder judiciário frente ao cresc

1 - A alimentação é um direito garantido a todos brasileiros na Constituição. Em sua opinião, quais as responsabilidades do poder executivo para garantia desse direito?

Expressões Chave

competência comum e as politicas publicas devem ser organizadas para garantir eșa alinentačo em todos os niveis da federaço, principalmente nos municíion que a base das politicas públicas sociais, com a açăo

supletiva dos estados e da Uniäo.

So que quando ele aplica o direito à vida ele também esqueceu que lá, na mesma constituiçăo diz que essa integralidade de atendimento é

mediante formulação de uma politica publica que ele não pode fazer. Juiz não formula politica publica. Isso é uma situaçăo dificill, porque vocêe esta aqui olho no olho, eu já tive presidente de sociedade de patologia que vieram brigar comigo pra dizer que, quando eu estava redigindo o

manual, há mais de 10 anos atrás nós redigimos um manual aqui que era sobre medicamentos excepcionais, dizendo que năo podia o governo

gastar dinheiro com medicação excepcional que näo passasse na ANVISA

ou que não tivesse autorizaçăo, exame do Ministerio da saúde, porque

época năo existia CONI TEC. Porque retirar do orçamento da execuçăo

financeira esse dinheiro poderia um cem numero de crianças morrer por

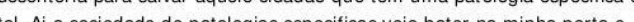

eu disse pra eles: olha lament Vou continuar detendendo essa tese. Eu

virei pernona não grata pra eles. Mas, essa é a situaça, o quadró é esse

O quadro é de progresso na medida em que diversos órgăo, pessoas e

entidades que cuidam de saúde publica, já estão convergindo no sentido

de diminuir a conflituosidade e litigiosidade entre o poder judiciário que é

acionado pelo demandante e o gestor de saúde. Eu pessoalmente estou

convencido que não é tarefa do poder judiciário alterar o planejamento do

gestor de saúde que já é objeto de controle externo dos conselhos

municipais, estaduais e nacional de saúde. Então, não é só uma questão

de exercício do poder discricionário, técnico e administrativo, típico do

poder executivo. O SUS já criou pela lei 8142 os conselhos de saúde que

são paritários entre usuários, profisssionais médicos e servidores para

regular e mitigar um pouco as politicas publicas. Então, quando você

servicos pa

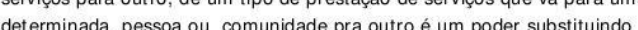

Outro. Eos poderes căo harmônicose indenendentes Entäo é sempre
I déia Central

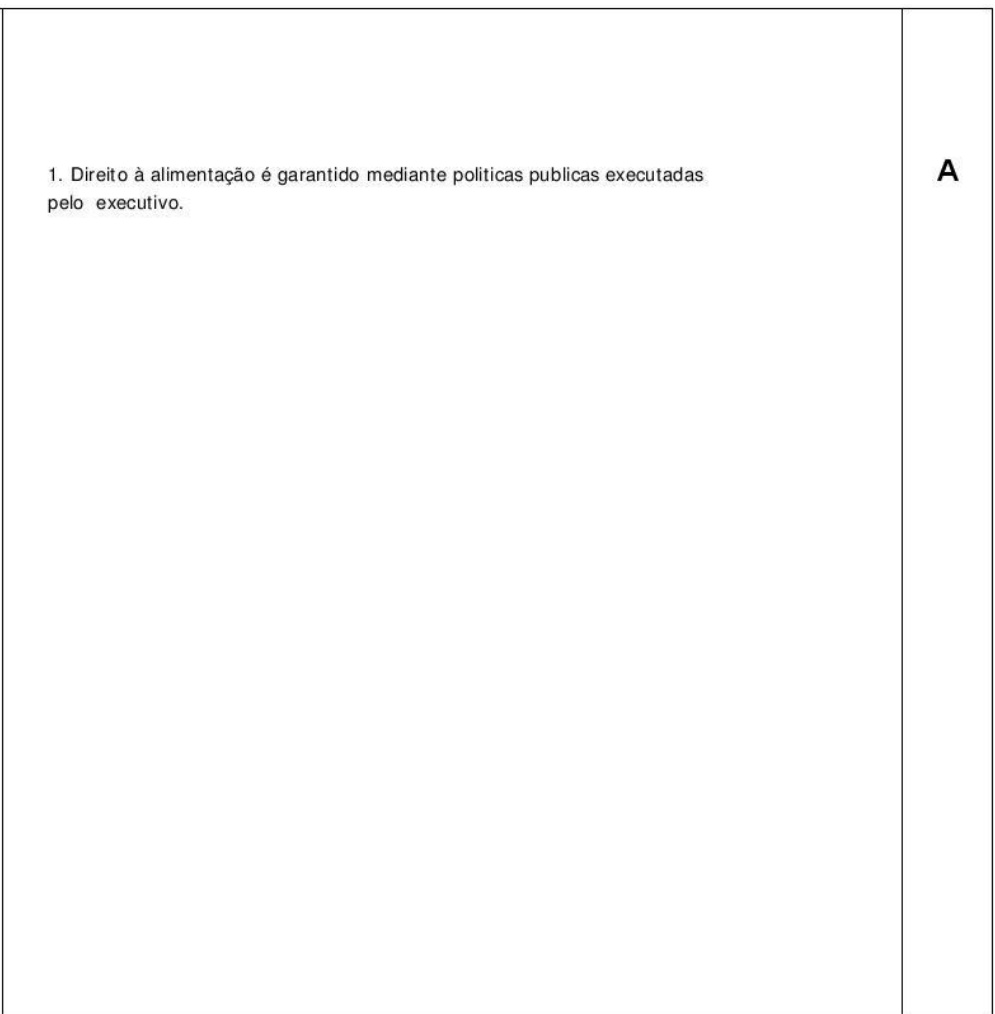


Acesso às fórmulas nutricionais para usuários do SUS: percepções do poder judiciário frente ao cresc

1 - A alimentação é um direito garantido a todos brasileiros na Constituição. Em sua opinião, quais as responsabilidades do poder executivo para garantia desse direito?

\begin{tabular}{|c|c|c|c|}
\hline & Expressōes Chave & Idéia Central & \\
\hline PROC2 & 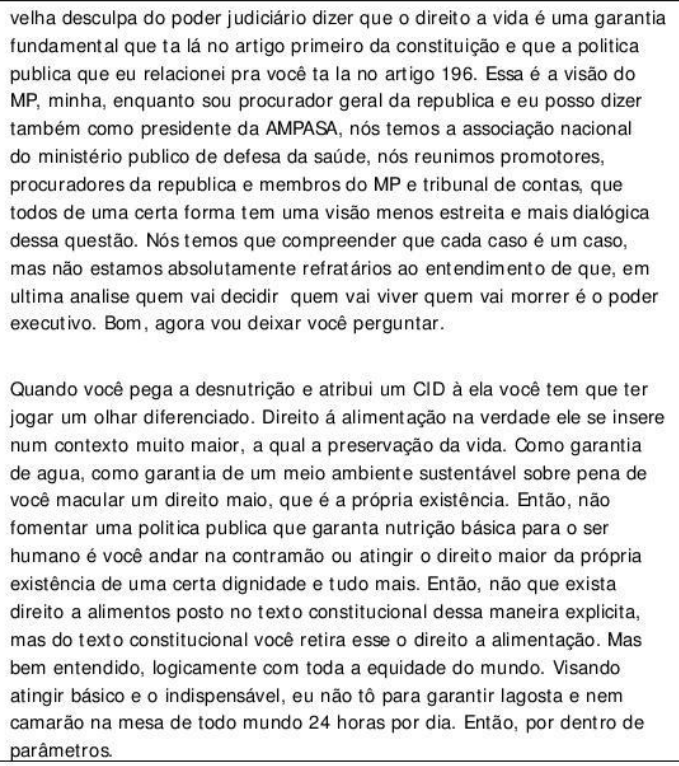 & $\begin{array}{l}\text { 1. o direito à alimentação deve ser garantido por meio de politicas } \\
\text { publicas para afixar os contornos desse direito e o que será dispensado } \\
\text { pelo poder publico. }\end{array}$ & A \\
\hline JUD3 & $\begin{array}{l}\text { Bom, eu acho que o poder executivo tem ampla possibilidade de garantir } \\
\text { esse direito, porque è da tarefa dele. O poder legislativo pode até fazer } \\
\text { normas quanto a isso, mas o poder judiciário na minha forma de ver tem } \\
\text { limitacöes. }\end{array}$ & 1. O poder executivo que garante de fato o direito à alimentaçăo. & $A$ \\
\hline PROC1 & $\begin{array}{l}\text { Uma politica de Estado não é algo que o estado deva efetivar, não é } \\
\text { assim que se pensa ela. Politica de Estado é um elemento do Estado. A }\end{array}$ & 2. Politicas públicas devem ser garantidas pelo poder executivo. & $A$ \\
\hline
\end{tabular}


QualiQuantiSoft巴 .

Maria Célia Delduque Nogueira Pires de Sa

Acesso às fórmulas nutricionais para usuários do SUS: percepções do poder judiciário frente ao cresc

1 - A alimentação é um direito garantido a todos brasileiros na Constituição. Em sua opinião, quais as responsabilidades do poder executivo para garantia desse direito?

\begin{tabular}{|c|c|c|c|}
\hline & Expressōes Chave & Idéia Central & \\
\hline AGU1 & 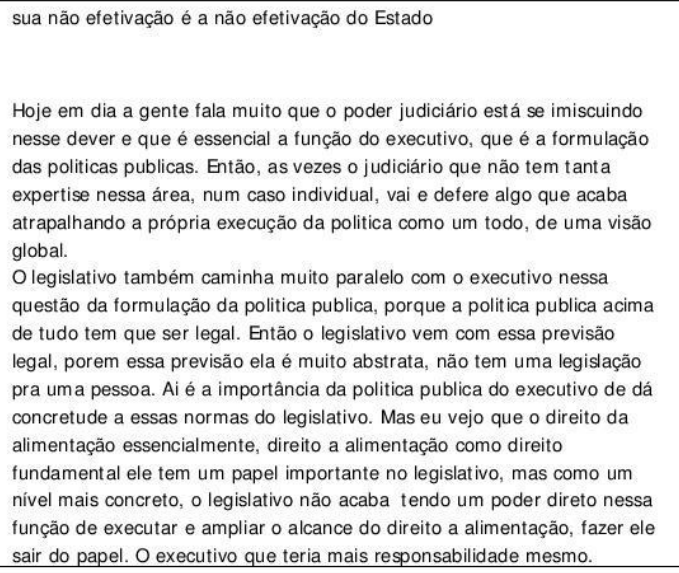 & $\begin{array}{l}\text { 2. o judiciario está se imiscuindo do papel do executivo e interferindo na } \\
\text { execuçăo da politica publica }\end{array}$ & B \\
\hline DEF1 & 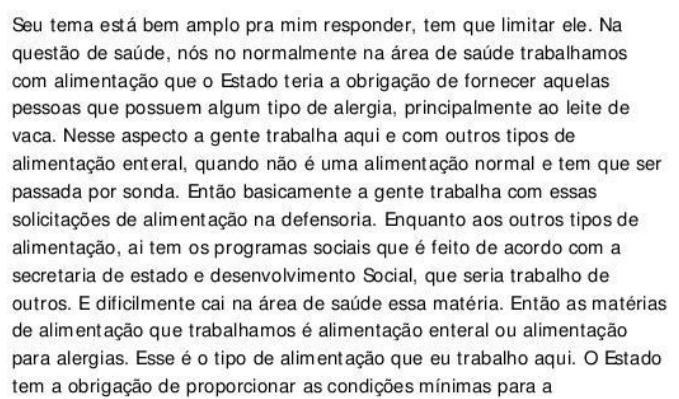 & $\begin{array}{l}\text { 2. O Judiciario vem garantindo as politicas publicas para a alimentaçäo } \\
\text { especial que impactam na melhora da saude dos indicividuso com } \\
\text { necessidades alimentares especiais. }\end{array}$ & B \\
\hline
\end{tabular}


Acesso às fórmulas nutricionais para usuários do SUS: percepções do poder judiciário frente ao cresc

1 - A alimentação é um direito garantido a todos brasileiros na Constituição. Em sua opinião, quais as responsabilidades do poder executivo para garantia desse direito?

Expressōes Chave

Idéia Central

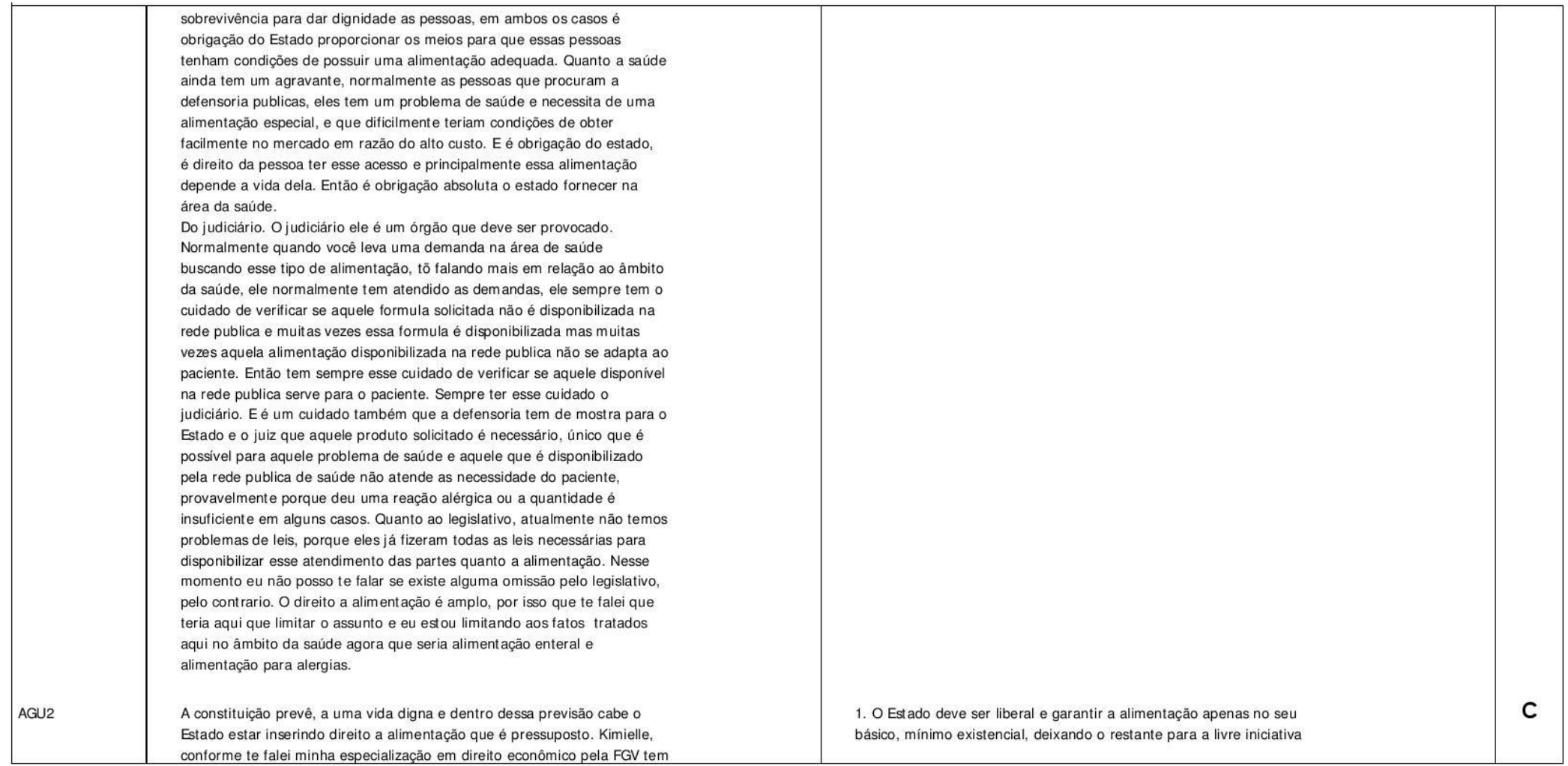


QualiQuantiSoft巴

Maria Célia Delduque Nogueira Pires de Sa

Acesso às fórmulas nutricionais para usuários do SUS: percepções do poder judiciário frente ao cresc

1 - A alimentação é um direito garantido a todos brasileiros na Constituição. Em sua opinião, quais as responsabilidades do poder executivo para garantia desse direito?

Expressōes Chave

I déia Central

\begin{tabular}{|c|c|c|c|}
\hline & 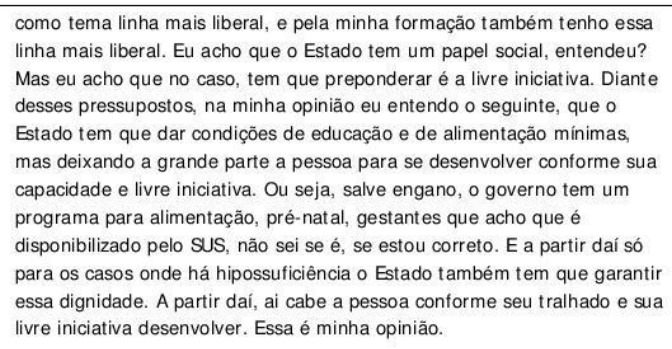 & 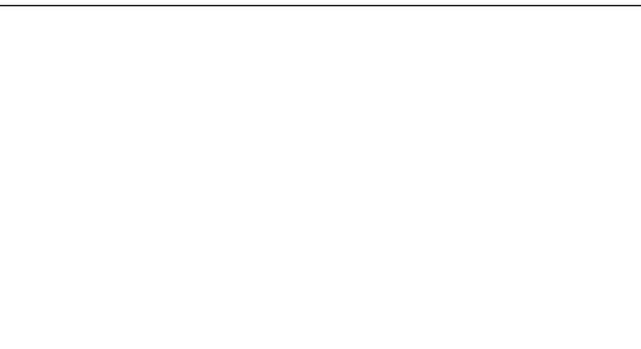 & \\
\hline AGU1 & 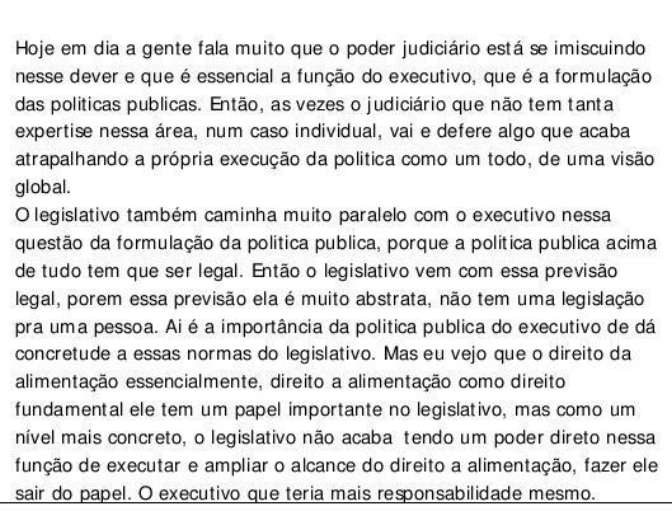 & $\begin{array}{l}\text { 2. O poder executuvo é o poder que tem mais expertise e capacidade } \\
\text { para concretizar esse direito }\end{array}$ & C \\
\hline PROC1 & $\begin{array}{l}\text { Veja bem, quando você diz que a alimentação é um direito garantido eu } \\
\text { fico pensando em que medida. Garantido formalmente, vocế quer dizer. } \\
\text { Porque materialmente nós temos muitos famélicos e subnutridos em }\end{array}$ & $\begin{array}{l}\text { 1. O direito á alimentação é garantido formalmente, pois materialmente } \\
\text { ele năo se concretizou, não está consolidado. }\end{array}$ & D \\
\hline
\end{tabular}


QualiQuantiSoft巴

Maria Célia Delduque Nogueira Pires de Sa

Acesso às fórmulas nutricionais para usuários do SUS: percepções do poder judiciário frente ao cresc

1 - A alimentação é um direito garantido a todos brasileiros na Constituição. Em sua opinião, quais as responsabilidades do poder executivo para garantia desse direito?

\begin{tabular}{|c|c|c|c|}
\hline & Expressōes Chave & I déia Central & \\
\hline JUD 4 & 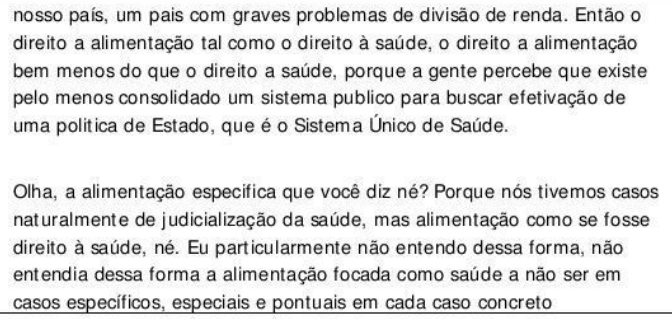 & 1. Direito à saúde é diferente de direito à alimentação. & $\mathbf{F}$ \\
\hline DEF1 & 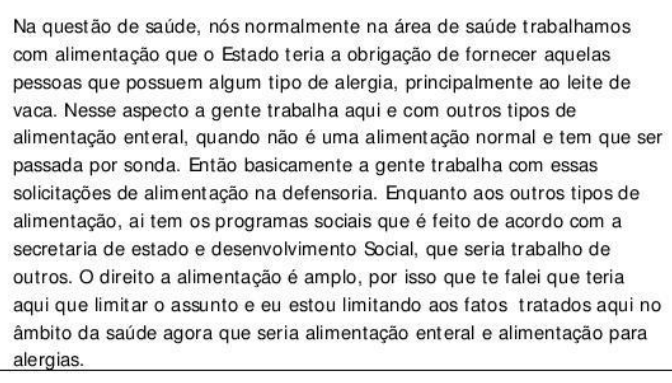 & $\begin{array}{l}\text { 2. O direito à alimentação é bem amplo, há questôes que perpassam a } \\
\text { area da saude e outras da assistencia social. }\end{array}$ & $\mathbf{F}$ \\
\hline DEF2 & $\begin{array}{l}\text { Bom, a alimentaçāo prevista na Constituição é mais volt ada para a } \\
\text { Segurança Alimentar do que a alimentaçâo no viés de saúde, né. }\end{array}$ & $\begin{array}{l}\text { 2. Direito à alimentação na Constituiçăo é mais voltada para Segurança } \\
\text { Alimentar do que para a saúde. }\end{array}$ & $\mathrm{F}$ \\
\hline JUD1 & $\begin{array}{l}\text { É obvio que o direito fundamental no Brasil, ele se tem uma percepção } \\
\text { um pouco diferente ou a aplicaçăo que sem feito principalmente pelo } \\
\text { judiciário no direito fundamental é que ele deve ser de um dia pro outro } \\
\text { ele deve ser concretizado. A caracteristica do direito fundamental social, e } \\
\text { o direito a alimentaçăo é um desse, ê que eles săo progressivos. Então }\end{array}$ & $\begin{array}{l}\text { 2. A característica do direito fundamental social, e o direito a alimentaçăo } \\
\text { é um desse, é que eles são progressivos. }\end{array}$ & $\mathbf{F}$ \\
\hline
\end{tabular}


QualiQuantiSoft巴

Maria Célia Delduque Nogueira Pires de Sa

Acesso às fórmulas nutricionais para usuários do SUS: percepções do poder judiciário frente ao cresc

1 - A alimentação é um direito garantido a todos brasileiros na Constituição. Em sua opinião, quais as responsabilidades do poder executivo para garantia desse direito?

\begin{tabular}{|c|c|c|c|}
\hline & Expressōes Chave & Idéia Central & \\
\hline JUD1 & 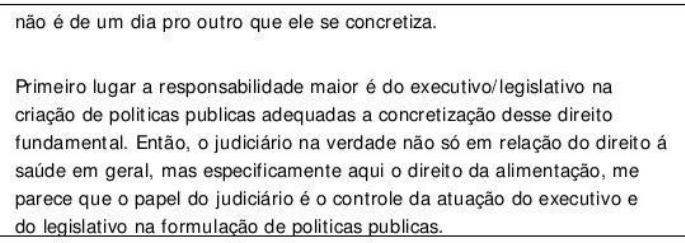 & $\begin{array}{l}\text { 1. Os poderes executivo e legislativo devem criar politicas publicas para } \\
\text { concretoizaçăo do direito à alimentaçăo que é um direito fundamental. E } \\
\text { o poder judiciário é o controle da execuçăao dessas politicas para garantia } \\
\text { desse direito }\end{array}$ & $\mathbf{H}$ \\
\hline PROC3 & 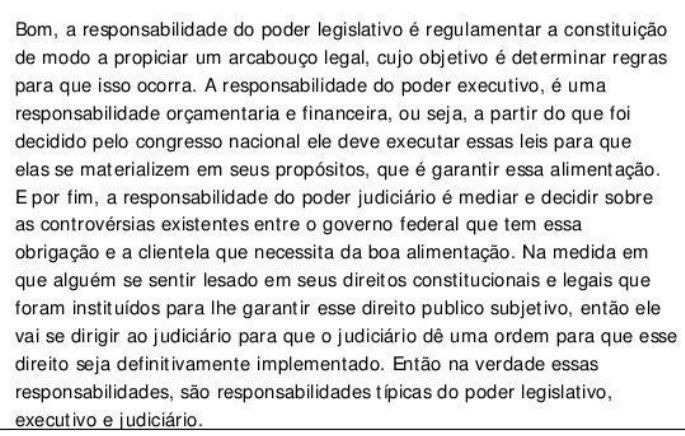 & $\begin{array}{l}\text { 2. Cada poder tem uma atribuição especifica para garantia do direito à } \\
\text { alimentação. }\end{array}$ & $\mathrm{H}$ \\
\hline PROC3 & $\begin{array}{l}\text { Ora, quem determina as politicas é o executivo, ta certo? E muitas vezes } \\
\text { é também o legislativo. Posso dizer pra vocế que a ultima grande } \\
\text { modificaçăo da lei } 8080 \text { foi exatamente mostrar para os juízes que eles } \\
\text { năo pociam prescrever medicamentos ou tratamentos especiais fora o } \\
\text { protocolo clinico e terapêutico. Esse é o artigo } 19 \text { na lei } 8080 \text {, alterado } \\
\text { pela } 12 \text { mil e năo sei tanto, esqueci e que diz o seguinte: O SUS só pode } \\
\text { fornecer remédiose tratamentos que tenham protocolo clinico e diretriz } \\
\text { terapêutica e que são incorporados ao SUS. Primeiro tem que passar na } \\
\text { ANVISA e depois na CONITEC }\end{array}$ & $\begin{array}{l}\text { 1. O poder executivo determina as politicas publicas e o judiciário não } \\
\text { pode interferir pois existem normativas bem definidas }\end{array}$ & $J$ \\
\hline
\end{tabular}


QualiQuantiSoft@ -

Maria Célia Delduque Nogueira Pires de Sá

$13 / 12 / 2015 \quad 16: 35$

Acesso às fórmulas nutricionais para usuários do SUS: percepções do poder judiciário frente ao cresc

1 - A alimentação é um direito garantido a todos brasileiros na Constituição. Em sua opinião, quais as responsabilidades do poder executivo para garantia desse direito?

Expressōes Chave

I déia Central

JUD3 $\quad$ Eu acredito que a responsabilidade do poder judiciário é a responsabilidade

e analisar aquilo que está previsto enrogramado na politica publica. Ou

2. O poder judiciário não pode criar politicas publicas para garantia do direito à alimentaçăa 


\section{APÊNDICE F- RESUMOS E IDEIAS: PERGUNTA № 2}

Acesso às fórmulas nutricionais para usuários do SUS: percepçães do poder judiciário frente ao cresc

2 -Algumas pessoas possuem necessidades alimentares especiais em que são prescritas fórmulas nutricionais industrializadas para alimentação. A judicialização do SUS para acesso a essas formulas tem se tornado crescente. $O$ (a) senhor (a) recebe esse tipo de

\begin{tabular}{|c|c|c|c|}
\hline & Expressōes Chave & I déia Central & \\
\hline AGU1 & 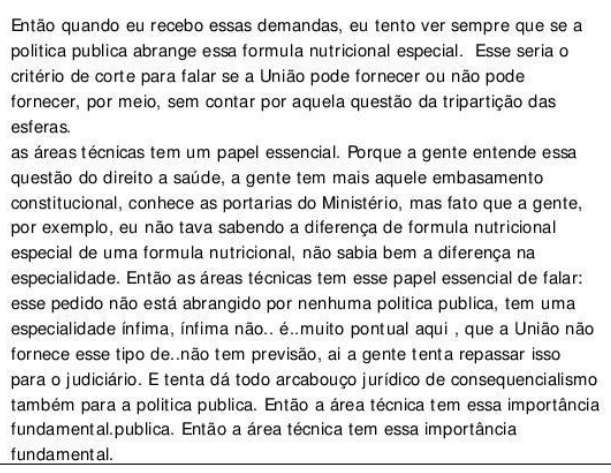 & $\begin{array}{l}\text { 1. sim. verifica se há previsão na politica publica e envia apara as areas } \\
\text { tecnicas para subsidio técnico. }\end{array}$ & A \\
\hline AGU2 & 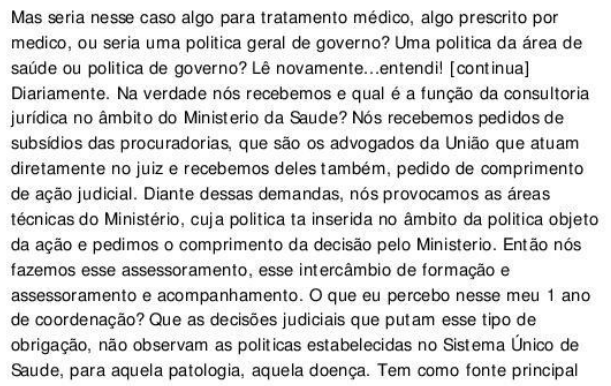 & $\begin{array}{l}\text { 1. sim. verifica se há previsāo na politica publica e envia apara as areas } \\
\text { tecnicas para subsidio técnico. }\end{array}$ & A \\
\hline
\end{tabular}


Acesso às fórmulas nutricionais para usuários do SUS: percepções do poder judiciário frente ao cresc

2 - Algumas pessoas possuem necessidades alimentares especiais em que são prescritas fórmulas nutricionais industrializadas para alimentação. A judicialização do SUS para acesso a essas formulas tem se tornado crescente. $O$ (a) senhor (a) recebe esse tipo de

\section{Expressões Chave}

I déia Central

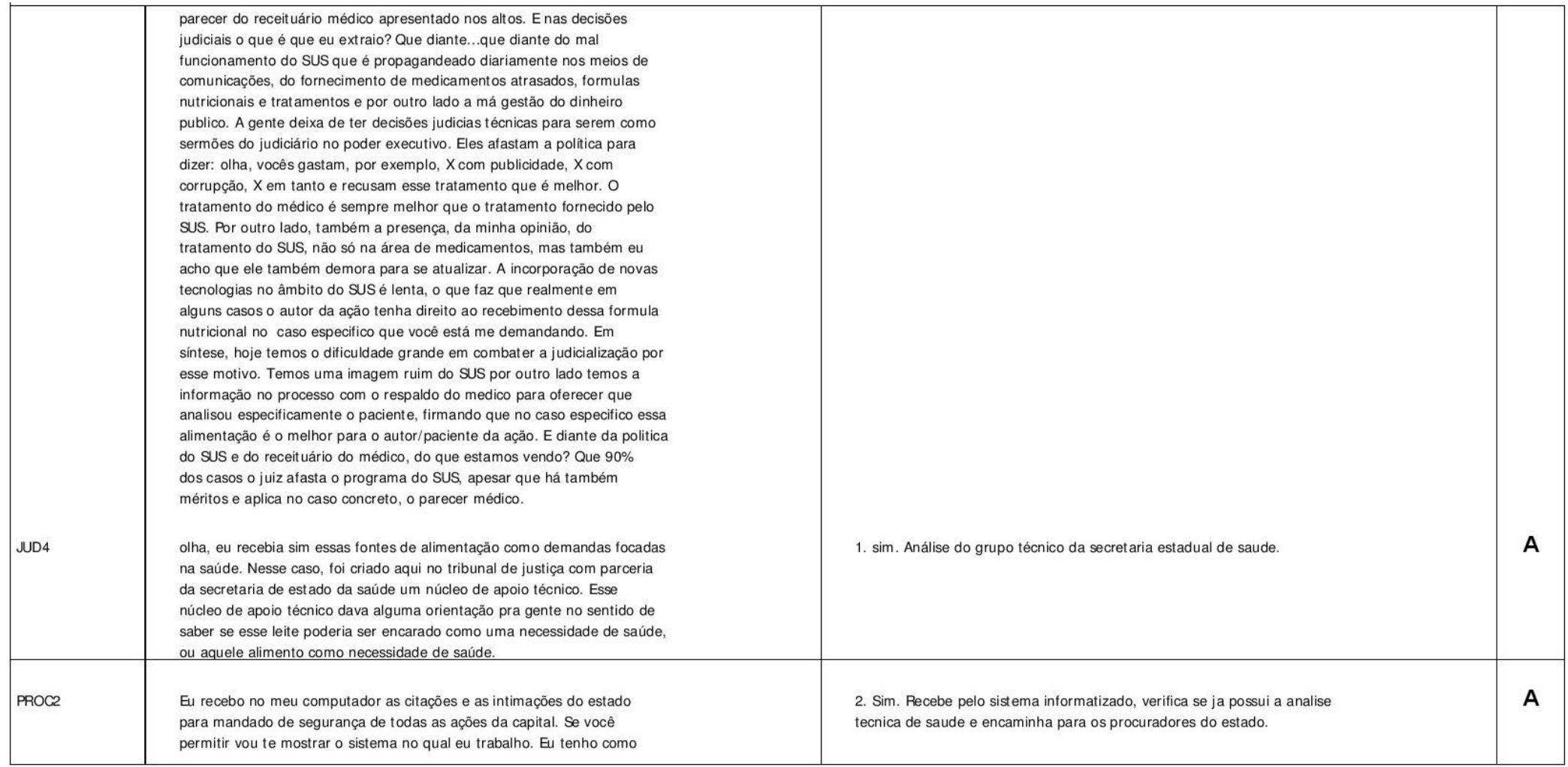


Acesso às fórmulas nutricionais para usuários do SUS: percepções do poder judiciário frente ao cresc

2 - Algumas pessoas possuem necessidades alimentares especiais em que são prescritas fórmulas nutricionais industrializadas para alimentação. A judicialização do SUS para acesso a essas formulas tem se tornado crescente. $O$ (a) senhor (a) recebe esse tipo de

Expressões Chave

\begin{tabular}{|c|c|}
\hline & 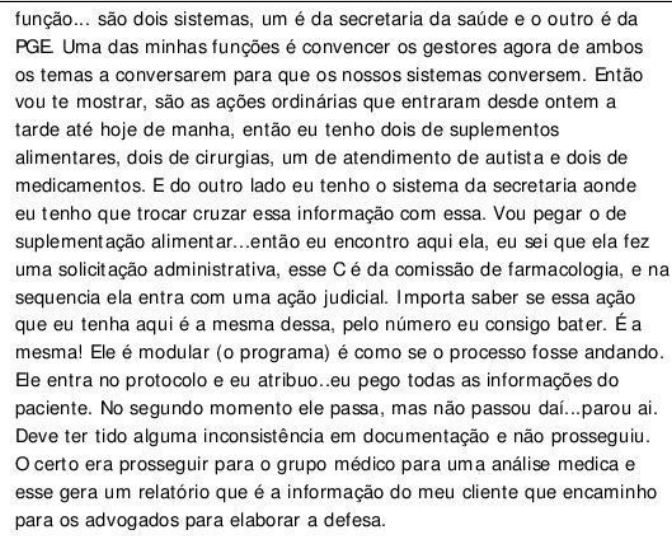 \\
\hline DEF1 & 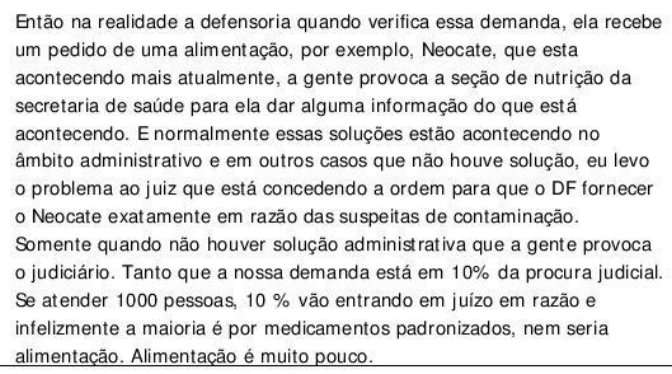 \\
\hline
\end{tabular}

Idéia Central

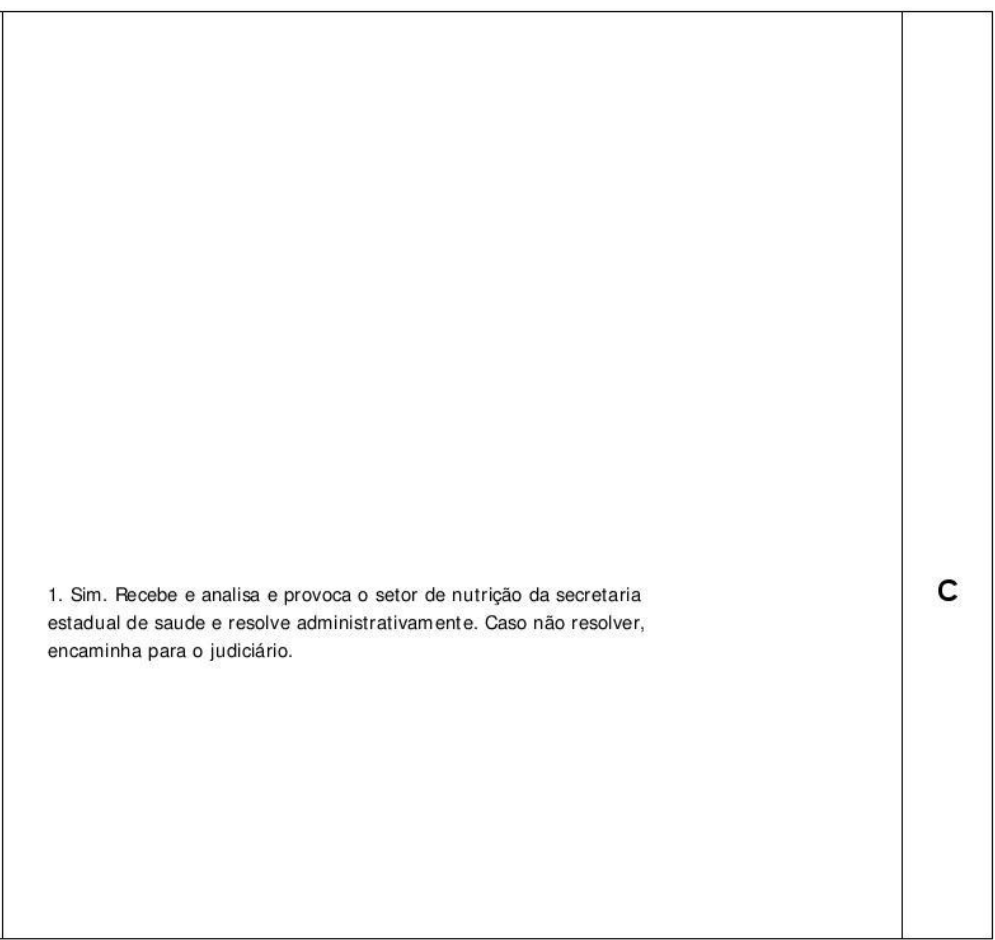


QualiQuantiSoft巴

Maria Célia Delduque Nogueira Pires de Sa

Acesso às fórmulas nutricionais para usuários do SUS: percepções do poder judiciário frente ao cresc

2 - Algumas pessoas possuem necessidades alimentares especiais em que são prescritas fórmulas nutricionais industrializadas para

alimentação. A judicialização do SUS para acesso a essas formulas tem se tornado crescente. $O$ (a) senhor (a) recebe esse tipo de

Expressōes Chave

I déia Central

\begin{tabular}{|c|c|c|c|}
\hline DEF2 & 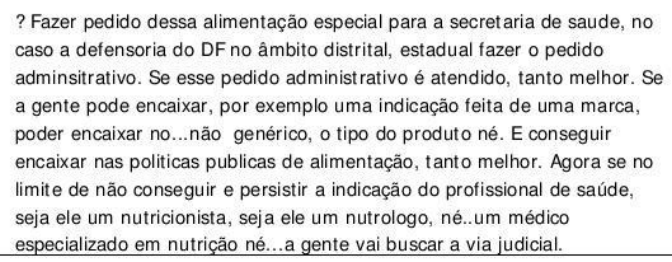 & $\begin{array}{l}\text { 1. Sim. Procura inserir a demandfa nas politicas publicas de alimentaçăo e } \\
\text { caso năo conseguir, faz pedido administrativo. }\end{array}$ & C \\
\hline PROC1 & $\begin{array}{l}\text { Veja bem, aqui nós estamos num campo limítrofe entre o direito sanitíário } \\
\text { e o direito a limentação. Porque nós estamos com um tipo de alimento } \\
\text { que ao mesmo tempo năo deixa de ser um remédio lato sensu, } \\
\text { medicamento. Entäo nós atuamos, como MP, no que diz respeito o } \\
\text { acesso a formulas nutricionais, considerando isso como um dever sanitário } \\
\text { do Estado, dever do suS. Veja bem o MP năo faz a defesa do direito } \\
\text { individualmente considerado. Nós ficamos no controle da politica publica } \\
\text { na efetivaçăo do direito no ponto de vista coletivo }\end{array}$ & 1. Sim. Com açōes coletivas. & C \\
\hline JUD3 & $\begin{array}{l}\text { achava que tinha que ter primeiro a indicacăa medica com a especificaçăo } \\
\text { da moléstia e da necessidade, eu entendia e entendo que precisa passar } \\
\text { por um parecer de outro medico e hoje entendo quere precisa estar } \\
\text { demonstrado em medicina baseada em evidencias que aquilo é } \\
\text { indispensável para o caso concreto. E mais que isso eu acho que tinha } \\
\text { que ter prévio o pedido administrativo. A pessoa deve requer pela } \\
\text { administraçăo publica aquilo que pretende, nesse caso as formulas } \\
\text { alimentares. Eu acho que a pessoa deve requerer o que ela pretende e } \\
\text { depois a administracăăo deve negar fundamentadamente }\end{array}$ & $\begin{array}{l}\text { 1. Sim. Solicitava que o autor verificasse na administraçăo publica a } \\
\text { disponibilidade da formula nutricional. Caso não tenha, negar de forma } \\
\text { fundamentada. }\end{array}$ & C \\
\hline PROC3 & $\begin{array}{l}\text { Não, hoje eu não recebo. Porque hoje eu oficio perante os tribunais } \\
\text { superiores. Quando eu recebia, anos atrás, quando eu oficiava a primeira } \\
\text { instancia, eu procurava entender as razōes do gestor de saúde. As razoes } \\
\text { pelas quais ele eventualmente não estaria a cumprir esse direito e na }\end{array}$ & $\begin{array}{l}\text { 1. Não. Mas quando oficiava procurava entender as razōes dos gestores } \\
\text { de saúde em năo cumprir esse direito. }\end{array}$ & D \\
\hline
\end{tabular}


QualiQuantiSoft巴

Maria Célia Delduque Nogueira Pires de Sa

Acesso às fórmulas nutricionais para usuários do SUS: percepções do poder judiciário frente ao cresc

2 - Algumas pessoas possuem necessidades alimentares especiais em que são prescritas fórmulas nutricionais industrializadas para

alimentação. A judicialização do SUS para acesso a essas formulas tem se tornado crescente. $O$ (a) senhor (a) recebe esse tipo de

Expressōes Chave

I déia Central

\begin{tabular}{|c|c|c|c|}
\hline PROC2 & 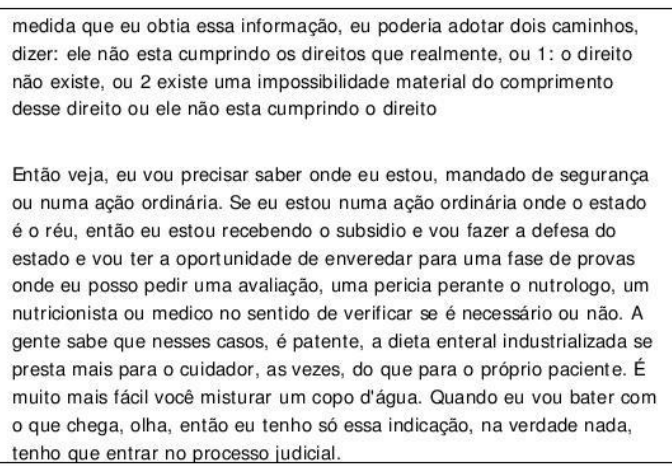 & $\begin{array}{l}\text { 3. ação ordinária onde o estado é o réu, entäo eu estou recebendo o } \\
\text { subsidio e vou fazer a defesa do estado e vou ter a oportunidade de } \\
\text { enveredar para uma fase de provas onde eu posso pedir uma avaliaçăo, } \\
\text { uma pericia perante o nutrologo, um nutricionista ou medico no sentido } \\
\text { de verificar se é necessário ou não. }\end{array}$ & D \\
\hline JUD1 & $\begin{array}{l}\text { Mas volto a dizer, como é um tema que como eu não tenho enfrentado, } \\
\text { um tema assim do dia a dia que eu tenha por tanto uma facilidade grande } \\
\text { de te dizer com absoluta certeza, sim é um criterio absoluto ou năo! Năo } \\
\text { tenha essa facilidade, essa tranquilidade de lhe dizer. }\end{array}$ & 1. Nāo. & $E$ \\
\hline JUD2 & Não. & Não. & $E$ \\
\hline DEF2 & $\begin{array}{l}\text { A pessoa năo tem renda, problema de assistênncia social. Năo tem renda } \\
\text { para acessar a alimentaçăo. Como ela năo tem renda pra acessar a } \\
\text { alimentaçăo, ela vai pedir pro Estado. Como as normas de segurança } \\
\text { alimentar e de alimentaçäo especial. Na verdade, normas de segurança } \\
\text { alimentar săo do Ministerio Desenvolvimento Social e a de merenda } \\
\text { escolar do Ministério da Educaçăo. Mas como a alimentaçăo especial de } \\
\text { pessoas com dificuldades, como alergias, com intolerâncias isso for } \\
\text { incorporado pelo Ministerio da Saude, pelas secretarias de saude e se } \\
\text { tornou uma demanda de saude. E uma demanda que é de alimentaçăo e }\end{array}$ & $\begin{array}{l}\text { 2. As quest öes assistencias de alimentaçãa refletem no sistema de saude } \\
\text { e o sistema de justiça usa dessa prerrogativa para entrar com suas açōes. }\end{array}$ & G \\
\hline
\end{tabular}


Acesso às fórmulas nutricionais para usuários do SUS: percepções do poder judiciário frente ao cresc

2 - Algumas pessoas possuem necessidades alimentares especiais em que são prescritas fórmulas nutricionais industrializadas para

alimentação. A judicialização do SUS para acesso a essas formulas tem se tornado crescente. $O$ (a) senhor (a) recebe esse tipo de

Expressōes Chave

I déia Central

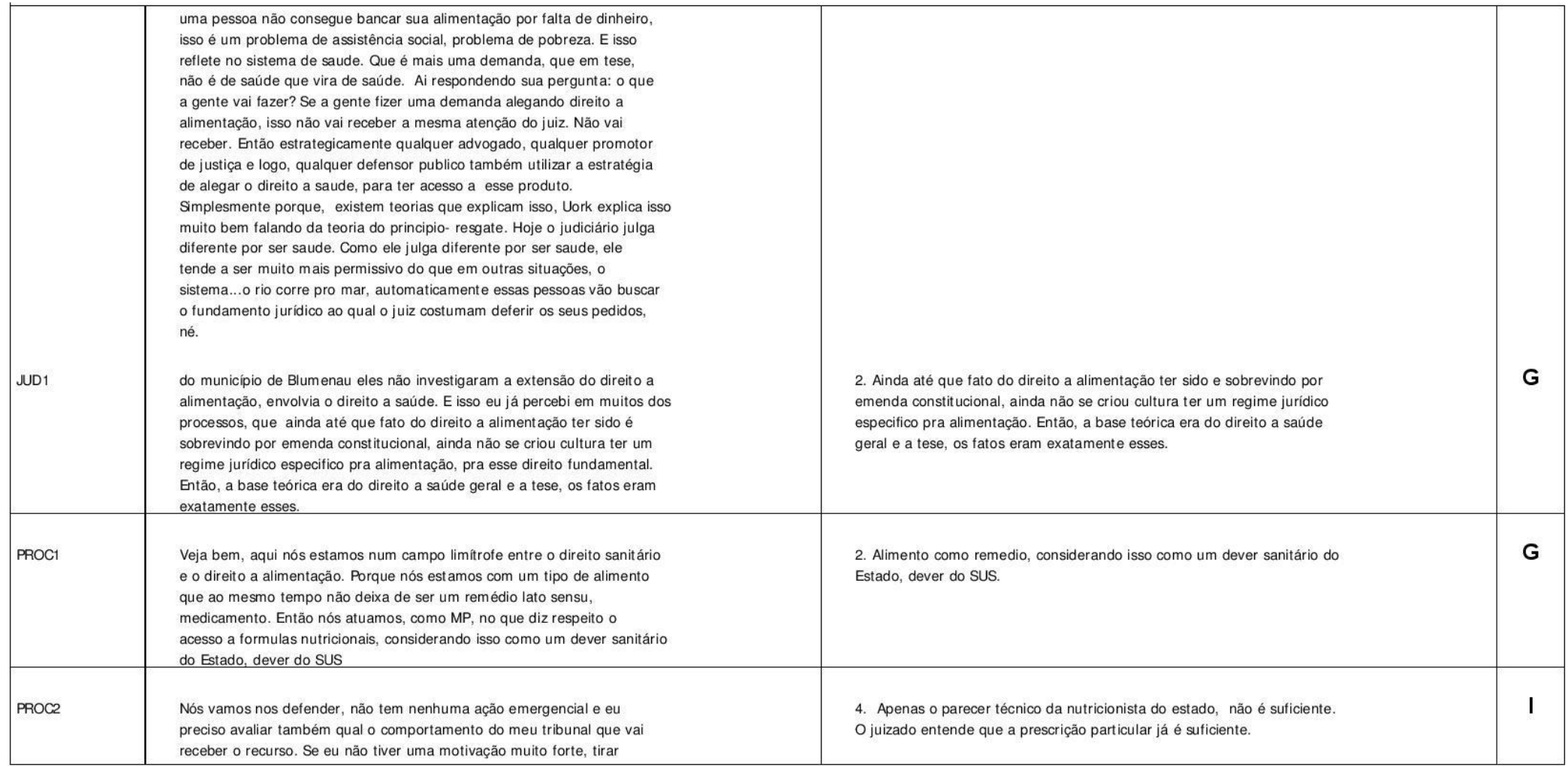


QualiQuantiSoft巴 -

Maria Célia Delduque Nogueira Pires de Sá

13/12/2015 16:37

Acesso às fórmulas nutricionais para usuários do SUS: percepções do poder judiciário frente ao cresc

2 - Algumas pessoas possuem necessidades alimentares especiais em que são prescritas fórmulas nutricionais industrializadas para

alimentação. A judicialização do SUS para acesso a essas formulas tem se tornado crescente. $O$ (a) senhor (a) recebe esse tipo de

Expressōes Chave

I déia Central

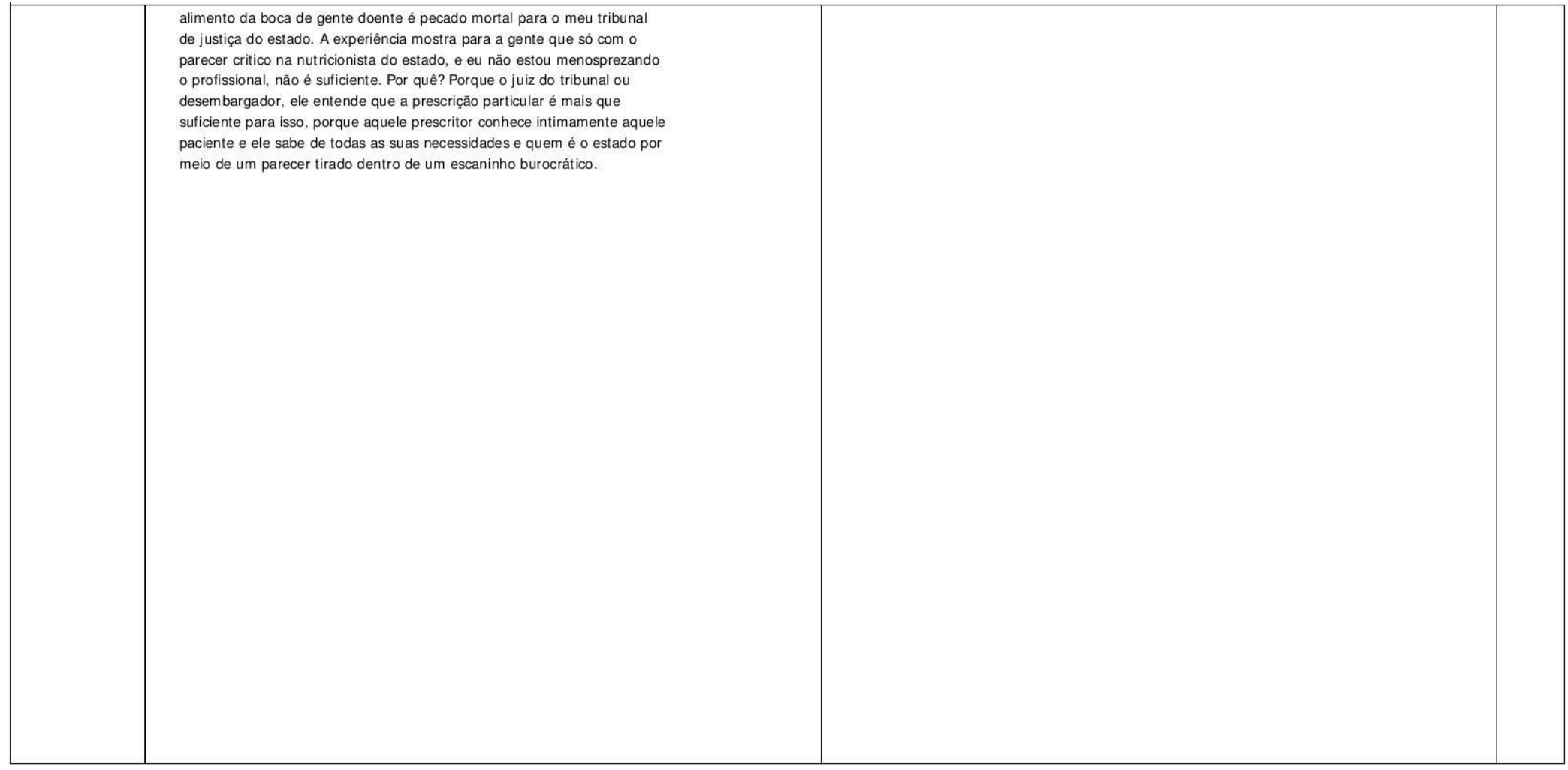




\section{APÊNDICE G- RESUMOS E IDEIAS: PERGUNTA № 3}

3 -Por se tratar de alimentos, o (a) senhor (a) considera que a análise dos processos de fórmulas nutricionais pode ser diferenciada dos processos de solicitação de medicament os? Por quê?

\begin{tabular}{|c|c|c|c|}
\hline & Expressōes Chave & Idéia Central & \\
\hline DEF2 & 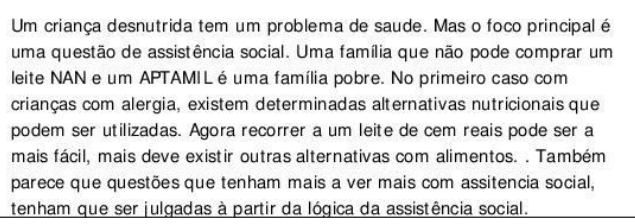 & $\begin{array}{l}\text { 2. Uma familia que não pode comprar um leite é uma familia pobre e } \\
\text { crianças com alergias podem usar outras alternativas alimentares. Nesse } \\
\text { caso, a questâo tem que ser julgada à apprtir da lógica da asssistencia social. }\end{array}$ & A \\
\hline DEF2 & $\begin{array}{l}\text { Bom, acho importante a gente diferenciar uma coisa. O que é uma } \\
\text { alimentaçäo derivada de um estado de saude muito complexo da pessoa e } \\
\text { o que é um problema de alimentaçăo derivada de uma causa comum do } \\
\text { desenvolvimento. . Agora, os casos que tem a ver com situaçōes } \\
\text { complexas de saude, como por exemplo pessoas acamadas e com } \\
\text { gastrostomias, realmente tem que ser abordado de forma mais } \\
\text { semelhante que a um medicamento. }\end{array}$ & $\begin{array}{l}\text { 1. Sequelas da alimentaçăo por agravos agravos de saude em que o } \\
\text { individuo necessite de via alternativa de alimentaçăo a alimentaçăo deve } \\
\text { ser abordada como medicamento. }\end{array}$ & C \\
\hline JUD2 & $\begin{array}{l}\text { Ovolume é muito pequeno e năo há análise differenciada, porque essas } \\
\text { alimentaçöes săo pedidase tratadas como medicament osas. Então a } \\
\text { análise é a mesma de acōes que se pede medicamentos. }\end{array}$ & 1. Não há analise diferenciada. & C \\
\hline JUD3 & $\begin{array}{l}\text { Eu pra falar a verdade acredito que não. Acho que os processos de } \\
\text { formulas nutricionaias guardam compatibilidade com as questöes } \\
\text { medicamentosas. Porque eu acho que embora o a alimento seja } \\
\text { indispensável para a vida de qualquer pessoa para se manter com a saúde } \\
\text { adequada e adequada alimentaçăo, eu acho que o estado é obrigado a } \\
\text { realizar aquilo que está nas politicas publicas e essas politicas publicas hoje } \\
\text { prevê a concessão de medicamentos alimentos quando houver uma } \\
\text { necessidade especial. }\end{array}$ & $\begin{array}{l}\text { 1. Não, pois os processos de fórmulas nutricionais guardam compatibilidade } \\
\text { com as questôes de medicamentos. }\end{array}$ & C \\
\hline PROC2 & $\begin{array}{l}\text { Na cabeça do juiz, năo! Do MP, não! Da defensoria, năo! Da procuradoria } \\
\text { geral do estado e da secretaria de saúde, sim! Sim mas vamos estabelecer } \\
\text { contexto, não que a medicaçăo seja algo superior, ela é differenciada. Aos }\end{array}$ & $\begin{array}{l}\text { 1. Do sistema de justiça não. Mas da peocuradoria sim. Pois medicamentos } \\
\text { săo drogas e com efeitos colaterias e medicamentos não e pode ser } \\
\text { obtido por outras fontes alimentares. }\end{array}$ & C \\
\hline
\end{tabular}


QualiQuantiSoft巴

Acesso às fórmulas nutricionais para usuários do SUS: percepções do poder judiciário frente ao cresc

3 - Por se tratar de alimentos, o (a) senhor (a) considera que a análise dos processos de fórmulas nut ricionais pode ser diferenciada dos processos de solicit ação de medicament os? Por quê?

\begin{tabular}{|c|c|c|c|}
\hline & Expressōes Chave & Idéia Central & \\
\hline AGU2 & 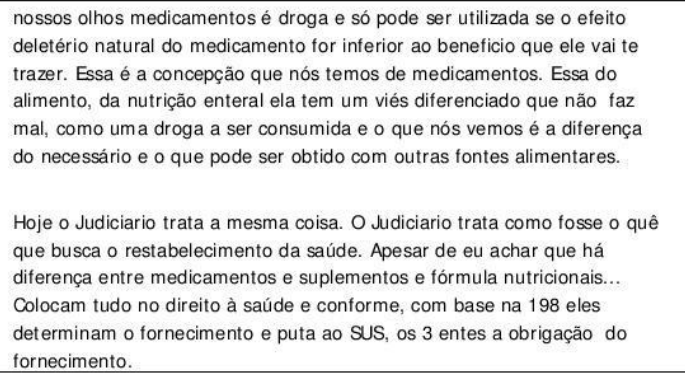 & 1. Sim. Mas o Judiciário trata como se fosse a mesma coisa. & D \\
\hline AGU1 & 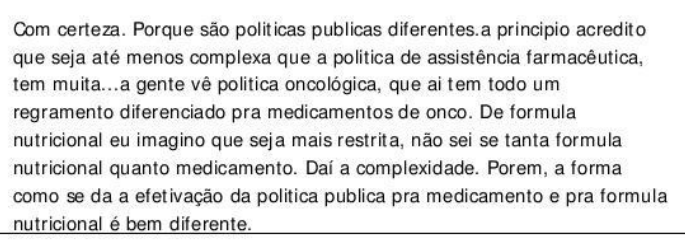 & $\begin{array}{l}\text { 1. Sim. Porquê säo politicas publicas diferentes com especificidades } \\
\text { diferentes. }\end{array}$ & $\mathbf{F}$ \\
\hline DEF1 & $\begin{array}{l}\text { Toda e qualquer demanda tem que ser diferenciada de acordo com o } \\
\text { objeto, não tem condição de você pegar e fazer uma regra geral para } \\
\text { todos. O medicamento ele tem sua urgência em razäo do tipo da doença } \\
\text { e a necessidade do paciente tomar e as consequências que há de vir. As } \\
\text { mesmas perguntas tem que ser feitas com a alimentacăa. }\end{array}$ & $\begin{array}{l}\text { 1. Demandas de medicamentos săo diferentes de alimentaçāo, nesse } \\
\text { sentido, a análise também tem que ser diferentes. }\end{array}$ & $\mathbf{F}$ \\
\hline JUD4 & $\begin{array}{l}\text { Eu acho que deve ser tratado de forma diferenciada, porque naquele } \\
\text { caso concreto a gente possa visualizar aquilo ali como uma necessidade de } \\
\text { saúde, dentro daquele conceito amplo de saúde da OMS ou não. Ou } \\
\text { como um caso de assistência social, um caso de sobrevivência alimentar. } \\
\text { Então acho que nâo só pode mas que deve ser analisado cada caso com }\end{array}$ & $\begin{array}{l}\text { 1. Sim. Pois em cada caso especifico deve ser analisado de acordo com os } \\
\text { conceitos da OMS. }\end{array}$ & $F$ \\
\hline
\end{tabular}


QualiQuantiSoft巴

Maria Célia Delduque Nogueira Pires de Sá

Acesso às fórmulas nutricionais para usuários do SUS: percepções do poder judiciário frente ao cresc

3 - Por se tratar de alimentos, o (a) senhor (a) considera que a análise dos processos de fórmulas nutricionais pode ser diferenciada dos processos de solicitação de medicament os? Por quê?

\begin{tabular}{|c|c|c|c|}
\hline & Expressōes Chave & Idéia Central & \\
\hline PROC1 & 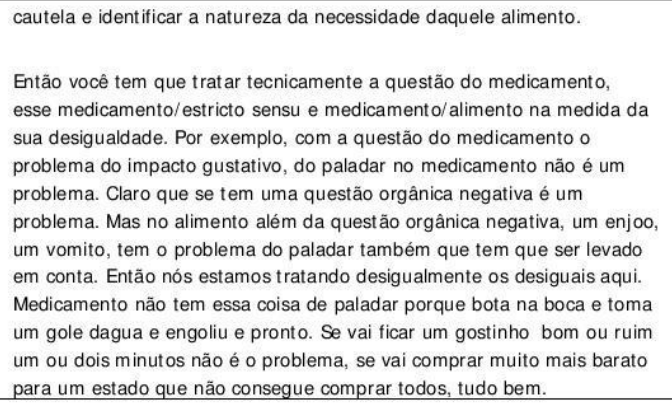 & $\begin{array}{l}\text { 1. Sim. Pois varias questões influenciam na aceitaçăo do alimento que é } \\
\text { diferente do medicamento }\end{array}$ & $\mathbf{F}$ \\
\hline PROC3 & $\begin{array}{l}\text { Eu acho que necessariamente săo por que os técnicos que vão avaliar as } \\
\text { necessidades nutricionais, que săo nutricionistas, são diferenciados de } \\
\text { técnicos que văo analisar a questão de medicamentos que são } \\
\text { farmacêuticos. Então certamente que os critérios técnicos e cientifficos } \\
\text { serăo diferenciados. }\end{array}$ & 1. Sim. Os critérios técnicos e cientificoss serão diferenciados. & $F$ \\
\hline
\end{tabular}




\section{APÊNDICE H- RESUMOS E IDEIAS: PERGUNTA № 4}

QualiQuantiSoft@

Maria Célia Delduque Nogueira Pires de Sá

Acesso às fórmulas nutricionais para usuários do SUS: percepçoes do poder judiciário frente ao cresc

4 - O que o senhor identifica como possiveis causas da judicialização para acesso às fórmulas nutricionais no sus?

\begin{tabular}{|c|c|c|c|}
\hline & Expressōes Chave & Idéia Central & \\
\hline AGU2 & 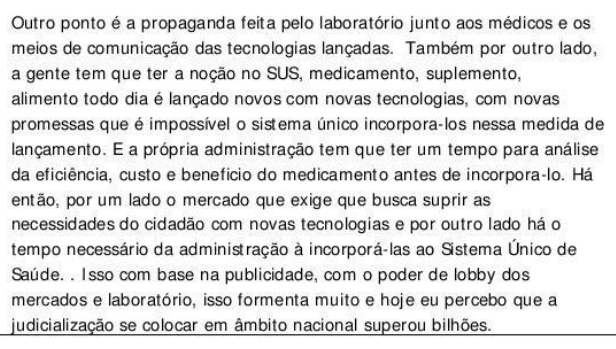 & 2. Lobby das industrias junto aos profissionais de saúde. & A \\
\hline DEF2 & 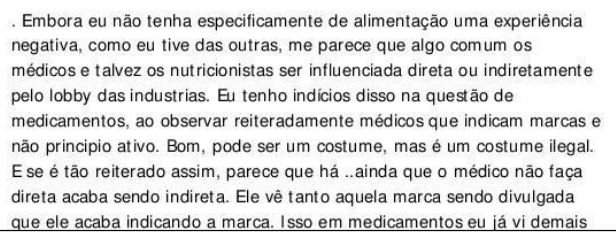 & 4. Lobby das industrias nos profissionais de saude & A \\
\hline JUD3 & 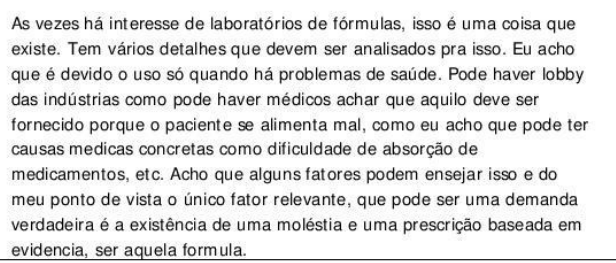 & 2. Lobby das industrias de alimentos & A \\
\hline
\end{tabular}


QualiQuantiSoft巴 -

Maria Célia Delduque Nogueira Pires de Sa

Acesso às fórmulas nutricionais para usuários do SUS: percepções do poder judiciário frente ao cresc

4 - 0 que o senhor identifica como possiveis causas da judicialização para acesso às fórmulas nutricionais no SUS?

\begin{tabular}{|c|c|c|c|}
\hline & Expressōes Chave & Idéia Central & \\
\hline JUD4 4 & 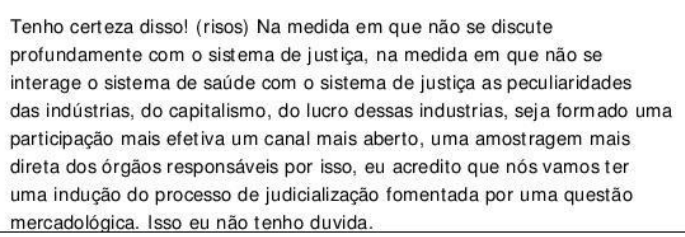 & 2. Lobby das industrias alimenticias & $A$ \\
\hline AGU2 & 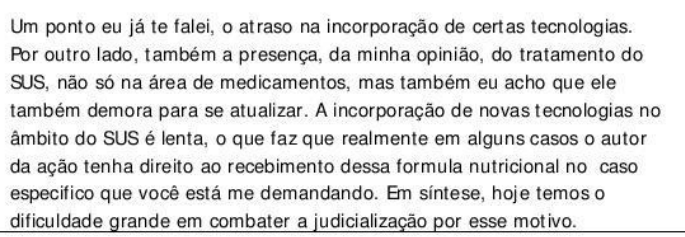 & 1. Morosidade na incorporaçăo de tecnologias no SUS. & B \\
\hline DEF2 & $\begin{array}{l}\text { demora pra incorporaçăo de tecnologias já testadas. Eo descompasso } \\
\text { entre o que há no mercado e o que o sus incorpora, quanto maior esse } \\
\text { descompasso, maior é a judicilizaçăo. Vai ser diretamente proporcional, se } \\
\text { o sus incorpora muito pouco do que o mercado oferece, as pessoas vao } \\
\text { demandar mais pra ter acesso. Esse pra mim säo dois efeitos principais }\end{array}$ & 2. Morosidade de incorporaçāo de tecnologias no SUS. & B \\
\hline PROC3 & 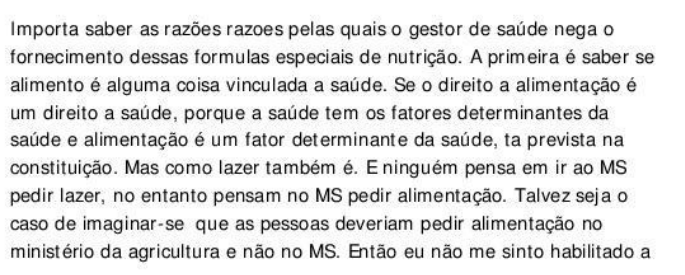 & $\begin{array}{l}\text { 1. Falta de entendimento do direito à alimentaçăo como condicionantes e } \\
\text { determinante da saude }\end{array}$ & D \\
\hline
\end{tabular}


QualiQuantiSoft巴

Maria Célia Delduque Nogueira Pires de Sa

Acesso às fórmulas nutricionais para usuários do SUS: percepções do poder judiciário frente ao cresc

4 - $O$ que o senhor identifica como possiveis causas da judicialização para acesso às fórmulas nutricionais no SUS?

\begin{tabular}{|c|c|c|c|}
\hline & Expressōes Chave & Idéia Central & \\
\hline DEF2 & 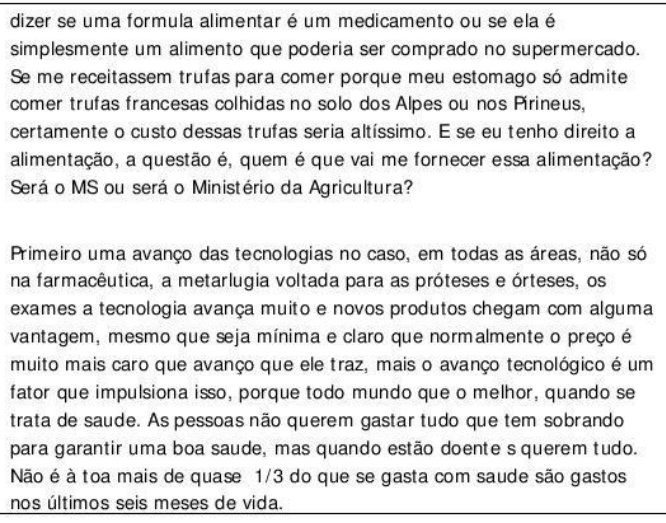 & 1. Avanços nas tecnologias em saude em geral & $\mathrm{E}$ \\
\hline JUD1 & $\begin{array}{l}\text { Em primeiro lugar uma deficiência de politica publica, principalmente em } \\
\text { municípios. }\end{array}$ & 1. Deficiencia na execuçäo de politicas publicas & $F$ \\
\hline JUD2 & $\begin{array}{l}\text { A causa é a falta de alimento/medicamento que o poder publico deveria } \\
\text { fornecer e năo fornece. Isso que demanda o ingresso da açăo judicial. }\end{array}$ & 1. Falta de politicas publicas para fornecimento dessas formulas & $F$ \\
\hline PROC1 & $\begin{array}{l}\text { São as mesmas causas da judicializaçăo dos medicamentos. É a mesma } \\
\text { causada judicializaçăo da saúde. Quais são as causas? O estado tem o } \\
\text { dever de prestar essas açōes, de prestar alimentos que também se } \\
\text { caracterizam como açóes de saúde. Na nosssa ótica a gente olha como } \\
\text { açāa de saúde e tem o dever e o cidadão tem o direito. }\end{array}$ & $\begin{array}{l}\text { 1. O Estado tem o dever de fornecer alimentos que caracterizam como } \\
\text { açăo de saude. }\end{array}$ & G \\
\hline JUD1 & $\begin{array}{l}\text { Em segundo lugar, eu acho que o principal é esse, uma ausência de } \\
\text { politicas. Até por que...eu acho que o ponto principal é esse, ainda há } \\
\text { uma baixa constitucionalidade do direito a alimentação. Baixa }\end{array}$ & 2. Ausência de politicas publicas para garantia do direito à alimentação & G \\
\hline
\end{tabular}


QualiQuantiSoft巴

Maria Célia Delduque Nogueira Pires de Sá

Acesso às fórmulas nutricionais para usuários do SUS: percepções do poder judiciário frente ao cresc

4 - $O$ que o senhor identifica como possiveis causas da judicialização para acesso às fórmulas nutricionais no SUS?

\begin{tabular}{|c|c|c|c|}
\hline & Expressōes Chave & Idéia Central & \\
\hline AGU1 & 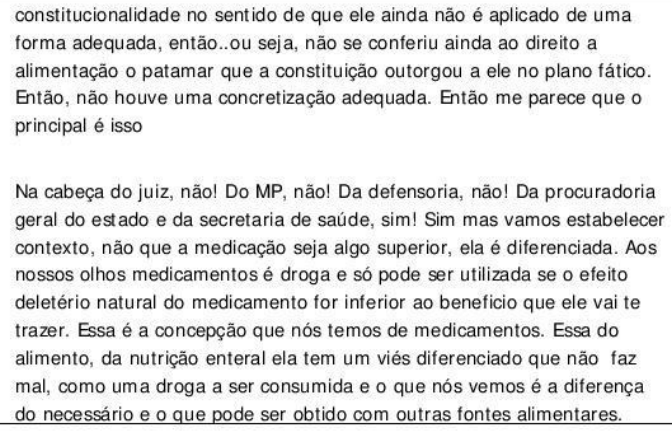 & 1. Falta de informação sobre o sUS e o que o SUS oferece. & $\mathrm{H}$ \\
\hline AGU2 & 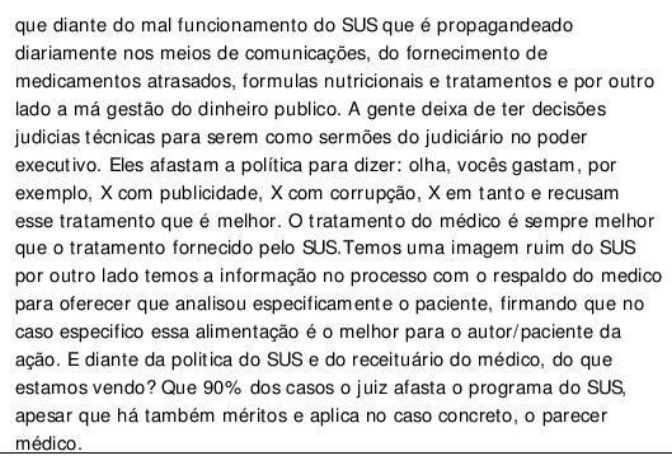 & 3. Imagem ruim do SUS perante o judiciario e propagandeado pela midia & $\mathrm{H}$ \\
\hline JUD3 & $\begin{array}{l}\text { : olha eu acho que pode ser diversas causas, tem vários pontos sensiveis } \\
\text { em relaçăo a isso. Uma das causas é efetivamente a necessidade do }\end{array}$ & 1. Prescriçōes medicas inadequadas & I \\
\hline
\end{tabular}


QualiQuantiSoft巴

Maria Célia Delduque Nogueira Pires de Sá

Acesso às fórmulas nutricionais para usuários do SUS: percepções do poder judiciário frente ao cresc

4 - $O$ que o senhor identifica como possiveis causas da judicialização para acesso às fórmulas nutricionais no SUS?

\begin{tabular}{|c|c|c|c|}
\hline & Expressōes Chave & Idéia Central & \\
\hline PROC2 & 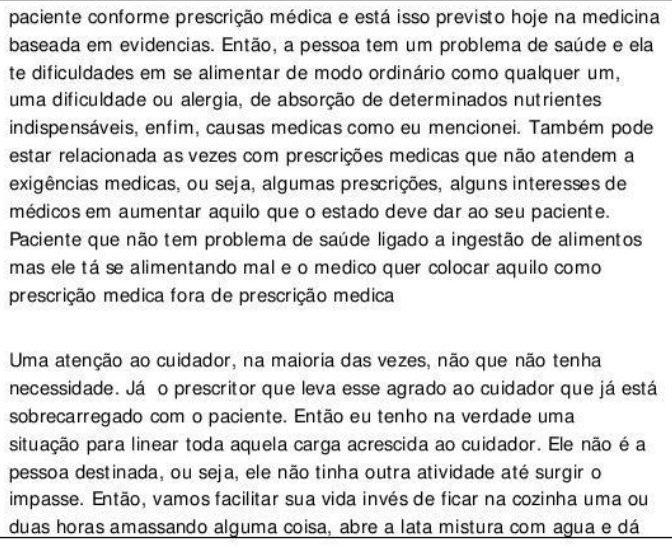 & $\begin{array}{l}\text { 1. O cuidador que força a judicializaçăo por essas formulas, para facilitar a } \\
\text { vida. }\end{array}$ & $\mathrm{I}$ \\
\hline AGU1 & 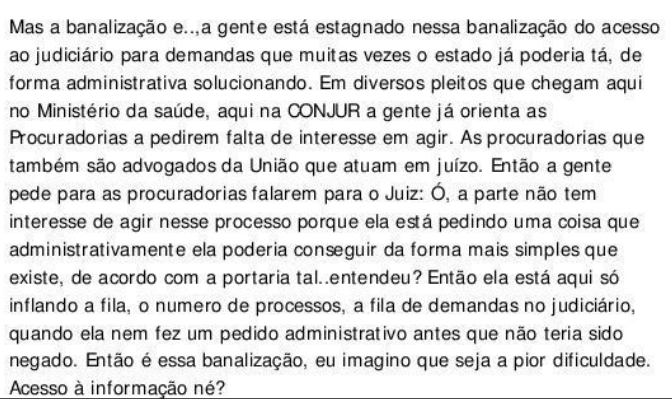 & 2. Banalizaçăo do acesso ao judiciário. & I \\
\hline
\end{tabular}


QualiQuantiSoft巴 -

Maria Célia Delduque Nogueira Pires de Sa

Acesso às fórmulas nutricionais para usuários do SUS: percepções do poder judiciário frente ao cresc

4 - $O$ que o senhor identifica como possiveis causas da judicialização para acesso às fórmulas nutricionais no SUS?

\begin{tabular}{|c|c|c|c|}
\hline & Expressōes Chave & Idéia Central & \\
\hline AGU2 & 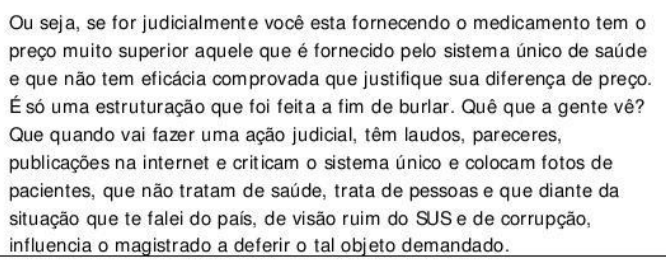 & $\begin{array}{l}\text { 4. fornecimento de formulas nutricionais sem a comprovação da eficácia } \\
\text { que justifique seu fornecimento pelo sus. }\end{array}$ & I \\
\hline DEF2 & 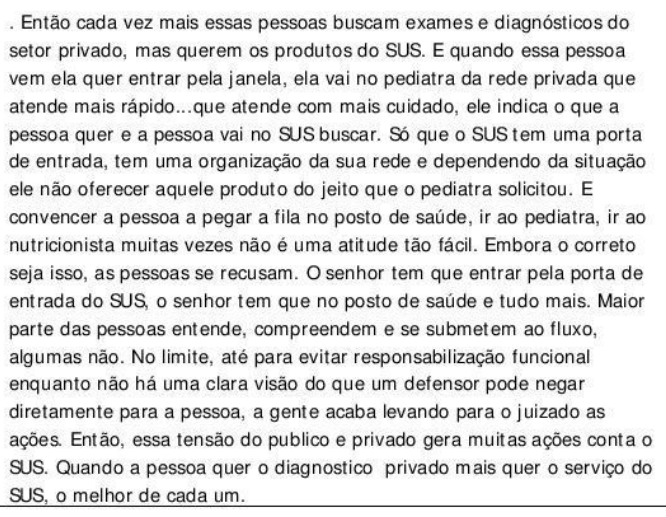 & 3. Tensão publico privado & $\mathrm{K}$ \\
\hline PROC1 & $\begin{array}{l}\text { O processo de consolidaçäo do privado como modo de realizaçăo das } \\
\text { açöes e serviços de saúde pelas terceirizaçōes e agora por esse terceiro } \\
\text { setor. É complicadissimo porque hoje a cartilha que se reza do MS e que } \\
\text { se vende para os estados e municipios é que a gestão seja terceirizada } \\
\text { para as organizaçōes sociais, as OS. Eo raciocínio para um brasileiro que }\end{array}$ & 2. Consolidação do sistema privado & $\mathrm{K}$ \\
\hline
\end{tabular}


QualiQuantiSoft巴 -

Maria Célia Delduque Nogueira Pires de Sá

$13 / 12 / 2015 \quad 16: 38$

Acesso às fórmulas nutricionais para usuários do SUS: percepções do poder judiciário frente ao cresc

4 - O que o senhor identifica como possiveis causas da judicialização para acesso às fórmulas nutricionais no SUS?

\begin{tabular}{|c|c|c|c|}
\hline & Expressōes Chave & Idéia Central & \\
\hline & $\begin{array}{l}\text { pensa um pouco a sua realidade e que tenha um pingo de lucidez e que } \\
\text { tenha coragem de pensar a coisa como ela é, o raciocinio năo é } \\
\text { complicado e as conclusōes são muito duras }\end{array}$ & & \\
\hline JUD1 & 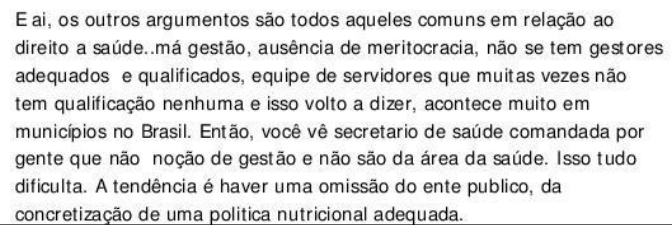 & 4. Servidores e gestão sem qualificaçăo & $\mathrm{L}$ \\
\hline
\end{tabular}




\section{APÊNDICE I- RESUMOS E IDEIAS: PERGUNTA № 5}

QualiQuantiSoft ${ }^{\circledR}$ -

Maria Célia Delduque Nogueira Pires de Sá

Acesso às fórmulas nutricionais para usuários do SUS: percepçōes do poder judiciário frente ao cresc

5 - O que o poder judiciário pode colaborar para resolução desses problemas?

\begin{tabular}{|c|c|c|c|}
\hline & Expressōes Chave & I déia Central & \\
\hline AGU1 & 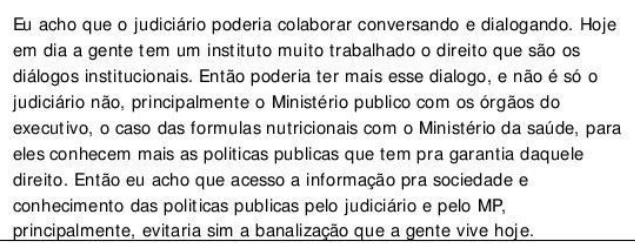 & 1. Sistema de Justiça e Sistema de Saúde manterem diálogos institucionais & A \\
\hline JUD4 & 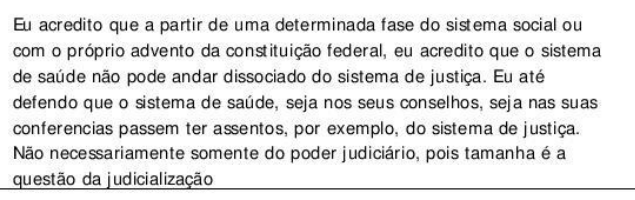 & 1. O sistema de saude não deve estar dissociado do sistema de justiça & A \\
\hline DEF2 & 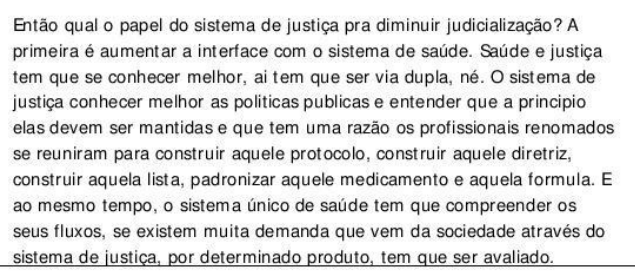 & $\begin{array}{l}\text { 1. Sistema de Justiça e Sistema de Saúde manterem diálogos } \\
\text { institucionais. }\end{array}$ & A \\
\hline PROC2 & $\begin{array}{l}\text { na verdade é ter vergonha na cara e enfrentar o direito sanitátí sem } \\
\text { preconceitos, se despojar um pouco da empáfia da classese dominante que } \\
\text { quer preservar no final o interesse seu. A postura do judicíario que eu } \\
\text { tenho aqui em SP é: eles defendem de uma maneira extrema que o }\end{array}$ & $\begin{array}{l}\text { 2. O judiciário tem ainda muito preconceito com as questöes sanitarias, de } \\
\text { saude publica }\end{array}$ & A \\
\hline
\end{tabular}


QualiQuantiSoft巴

Maria Célia Delduque Nogueira Pires de Sá

Acesso às fórmulas nutricionais para usuários do SUS: percepções do poder judiciário frente ao cresc

5 - O que o poder judiciário pode colaborar para resolução desses problemas?

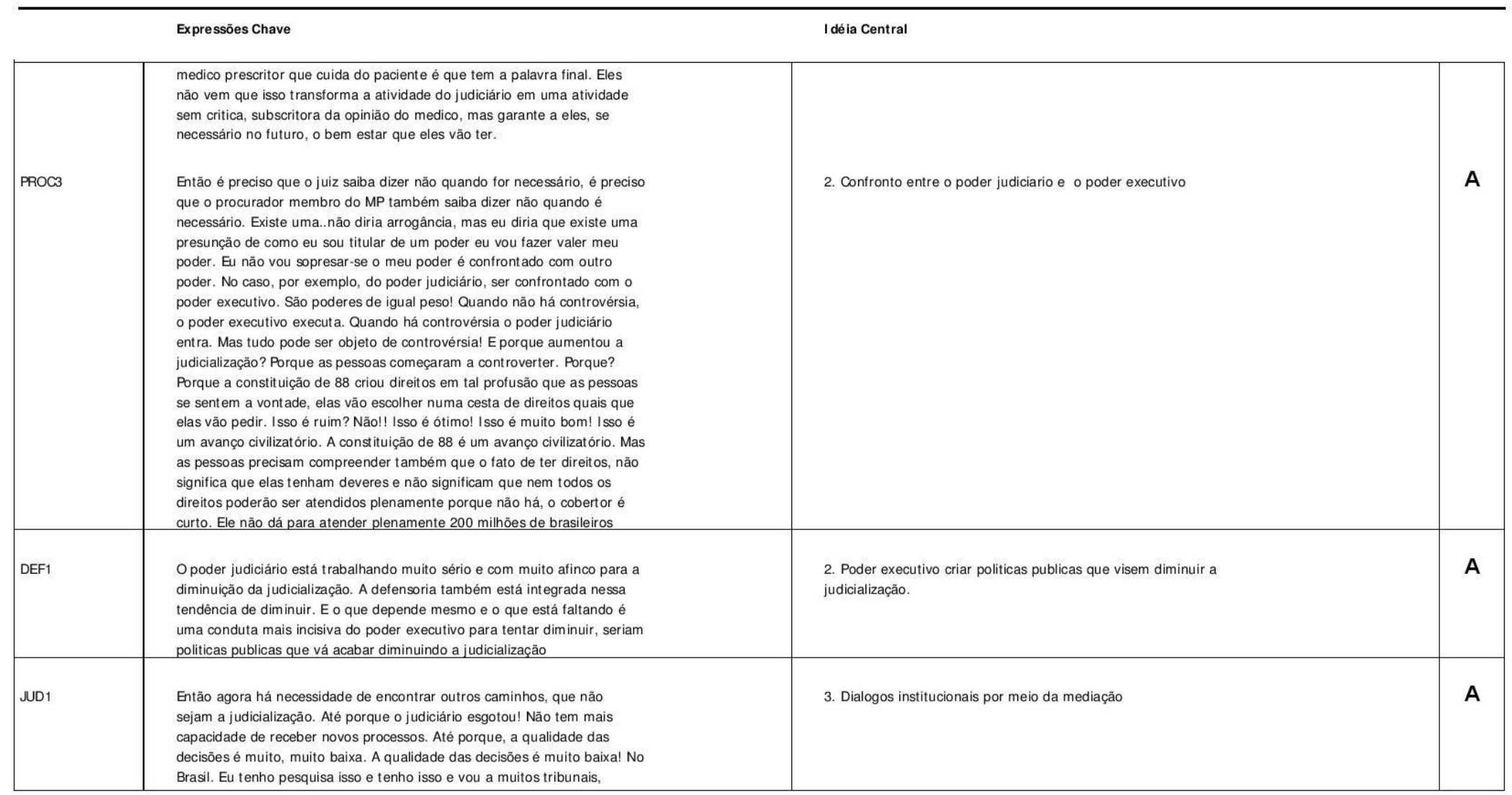


QualiQuantiSoft巴

Maria Célia Delduque Nogueira Pires de Sá

Acesso às fórmulas nutricionais para usuários do SUS: percepções do poder judiciário frente ao cres

5 - O que o poder judiciário pode colaborar para resolução desses problemas?

\begin{tabular}{|c|c|c|c|}
\hline & Expressōes Chave & Idéia Central & \\
\hline AGU2 & 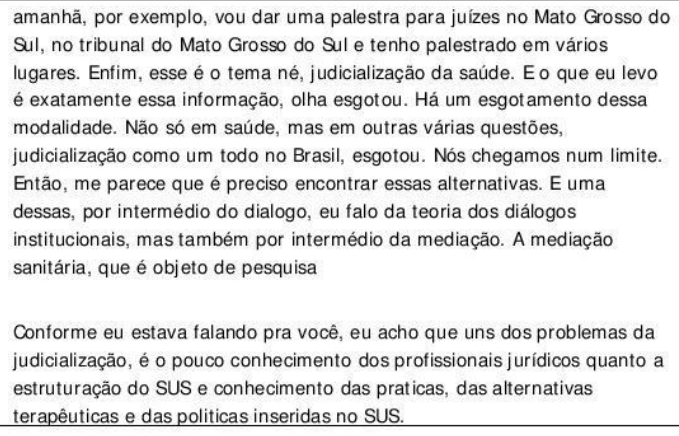 & $\begin{array}{l}\text { 1. Melhorar a compreensăo por parte do Poder Judiciário acerca da } \\
\text { organizaçẫo e funcionamento do SuS. }\end{array}$ & B \\
\hline PROC3 & 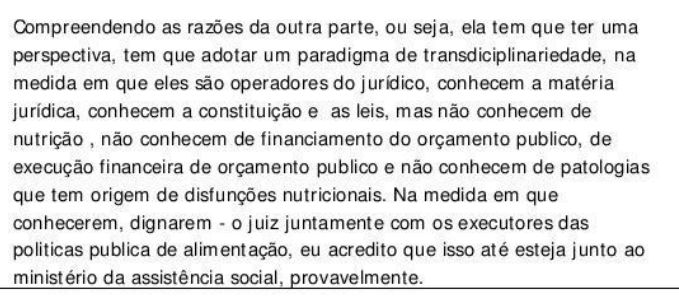 & 1. Desconhecimento do sistema judiciario sobre a complexidade do SUS & B \\
\hline PROC2 & 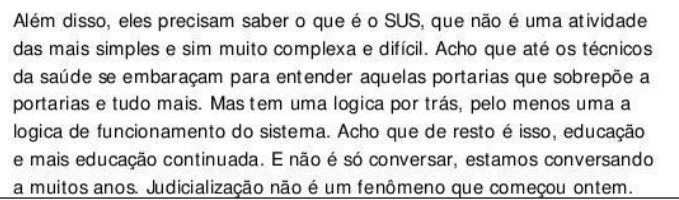 & $\begin{array}{l}\text { 1. Falta de conhecimento do sistema judiciário sobre a complexidade do } \\
\text { sistema de saude }\end{array}$ & B \\
\hline
\end{tabular}


QualiQuantiSoft巴

Maria Célia Delduque Nogueira Pires de Sá

Acesso às fórmulas nutricionais para usuários do SUS: percepções do poder judiciário frente ao cresc

5 - O que o poder judiciário pode colaborar para resolução desses problemas?

\begin{tabular}{|c|c|c|c|}
\hline & Expressōes Chave & Idéia Central & \\
\hline JUD4 4 & $\begin{array}{l}\text { Mas antes q eu se chegue a esse ponto que haja um envolvimento mais } \\
\text { direito e mais eficaz do sistema de justiça, inclusive na concepçäo de } \\
\text { politicas publicas. Com assento seja em conselhos municipais, estaduais das } \\
\text { conferencias de saúde. }\end{array}$ & 2. Envolvimento do sistema de justica na concepçăo de politicas publicas & B \\
\hline DEF2 & 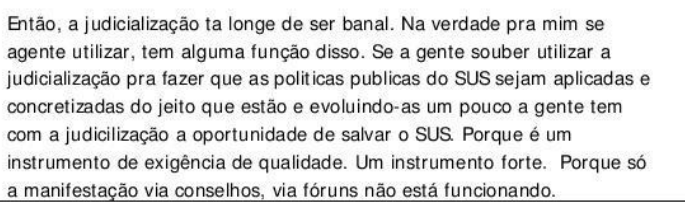 & 3. Judicialização como ferramenta de qualidade da gestâo de saude & B \\
\hline DEF1 & 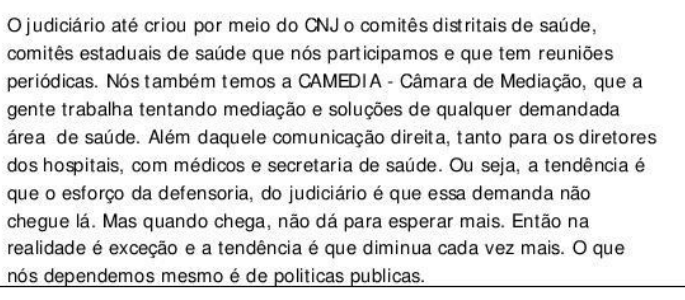 & 1. Contribuir para as estratégias de Mediaçäo Sanitária. & C \\
\hline PROC1 & 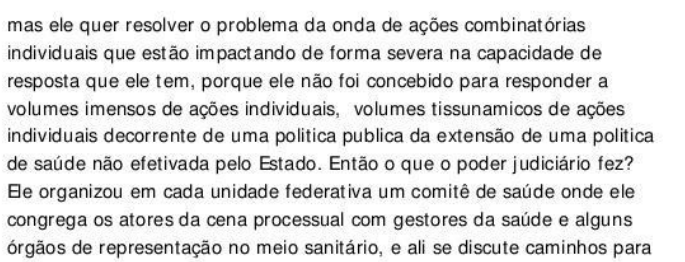 & $\begin{array}{l}\text { 1. Realizaçäo de comites de saude para solucionar por via administrativa os } \\
\text { conflitos }\end{array}$ & C \\
\hline
\end{tabular}


QualiQuantiSoft巴 -

Maria Célia Delduque Nogueira Pires de Sa

Acesso às fórmulas nutricionais para usuários do SUS: percepções do poder judiciário frente ao cresc

5 - O que o poder judiciário pode colaborar para resolução desses problemas?

\begin{tabular}{|c|c|c|c|}
\hline & Expressōes Chave & Idéia Central & \\
\hline PROC3 & $\begin{array}{l}\text { soluçăo pela via administrativa, para que esses conflitos de não efetivaçăo } \\
\text { setorial da politica não cheguem as barras dos tribunais, inclusive as } \\
\text { questão da fibrose cística já foi objeto de discussão nessa instancia aqui no } \\
\text { DF o comitê distrital de saúde que é um órgăo do conselho nacional de } \\
\text { justica, presidido por um magistrado nomeado pelo chefe do tribunal de } \\
\text { justiça local. } \\
\text { Então nós teríamos por meio de processos de mediação a possibilidade } \\
\text { de diminuir essa conflituosidade elitigiosidade }\end{array}$ & 4. Processos de mediaçăo & C \\
\hline DEF2 & 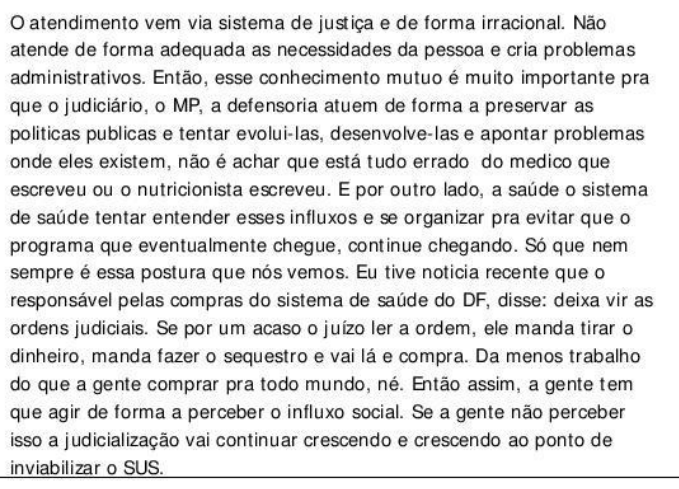 & $\begin{array}{l}\text { 3. O sistema de saude entender os influxos e organizar as politicas publicas } \\
\text { de saude }\end{array}$ & C \\
\hline JUD1 & 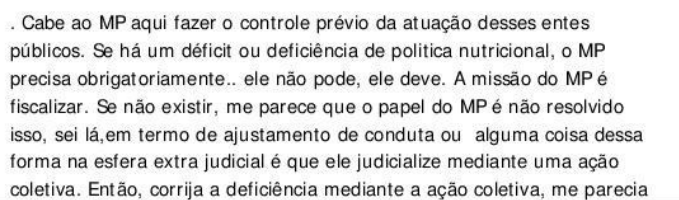 & $\begin{array}{l}\text { 1. Ministério Público realizar o controle da atuaçăo das politicas publicas de } \\
\text { alimentaçăo }\end{array}$ & $\mathrm{E}$ \\
\hline
\end{tabular}


QualiQuantiSoft巴

Maria Célia Delduque Nogueira Pires de Sá

Acesso às fórmulas nutricionais para usuários do SUS: percepções do poder judiciário frente ao cresc

5 - O que o poder judiciário pode colaborar para resolução desses problemas?

\begin{tabular}{|c|c|c|c|}
\hline & Expressōes Chave & Idéia Central & \\
\hline JUD3 & 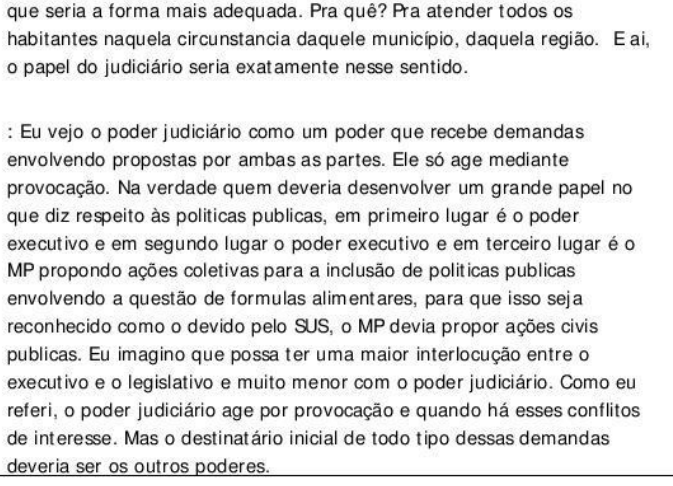 & 1. O MP propor mais açōes civis publicas & $\mathrm{E}$ \\
\hline AGU2 & 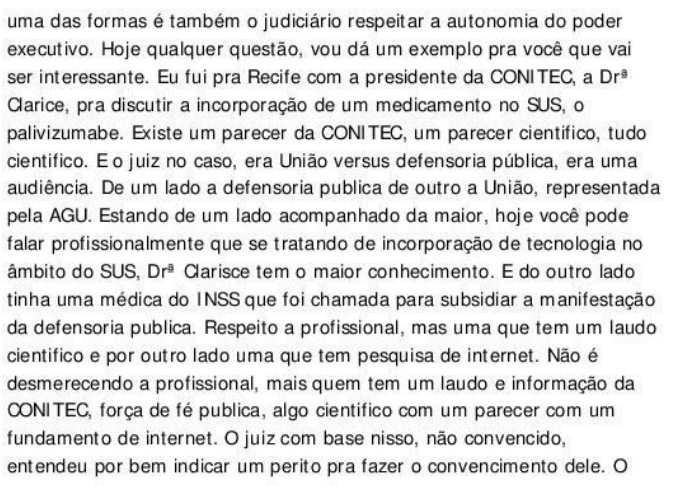 & $\begin{array}{l}\text { 2. Judiciário respeitar a autononomia do poder executivo e atuar nos } \\
\text { casos de omissão e erro }\end{array}$ & I \\
\hline
\end{tabular}


QualiQuantiSoft巴

Maria Célia Delduque Nogueira Pires de Sá

Acesso às fórmulas nutricionais para usuários do SUS: percepções do poder judiciário frente ao cresc

5 - O que o poder judiciário pode colaborar para resolução desses problemas?

\begin{tabular}{|c|c|c|c|}
\hline & Expressōes Chave & \multicolumn{2}{|l|}{ Idéia Central } \\
\hline & 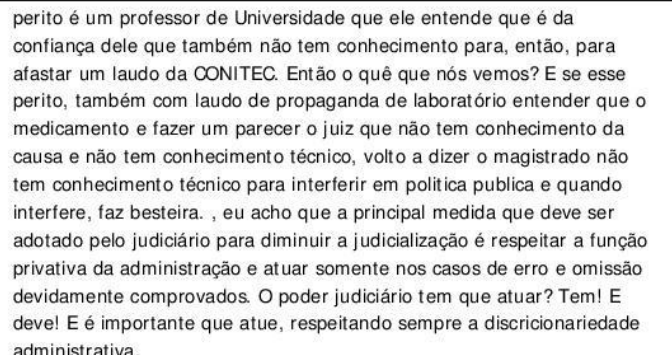 & & \\
\hline PROC3 & 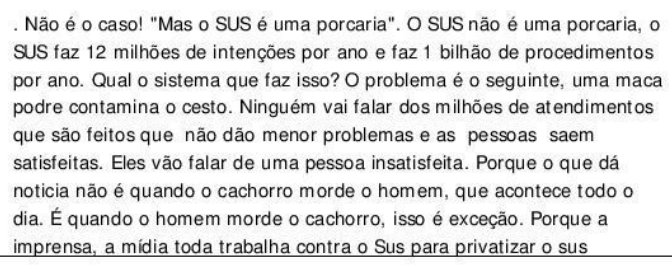 & 3. O trabalho da midia contra o SUS & $\mathrm{K}$ \\
\hline DEF2 & 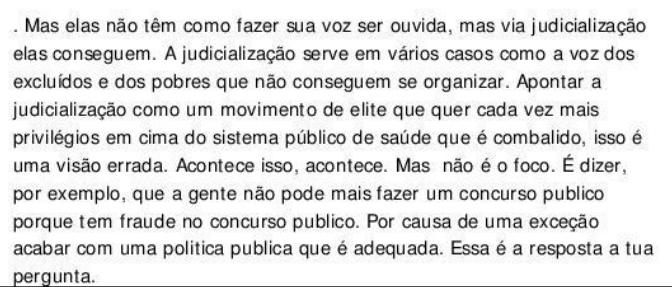 & $\begin{array}{l}\text { 4. A judicialização serve em vários casos como a voz dos excluídos e dos } \\
\text { pobres que năo conseguem se organizar }\end{array}$ & M \\
\hline
\end{tabular}


QualiQuantiSoft巴 -

Maria Célia Delduque Nogueira Pires de Sá

$13 / 12 / 2015 \quad 16: 39$

Acesso às fórmulas nutricionais para usuários do SUS: percepções do poder judiciário frente ao cresc

5 - O que o poder judiciário pode colaborar para resolução desses problemas?

\begin{tabular}{|c|c|c|c|}
\hline & Expressōes Chave & Idéia Central & \\
\hline JUD1 & 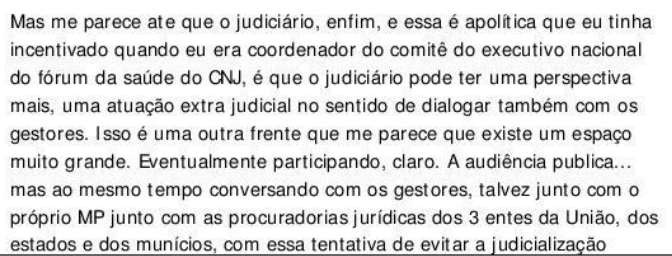 & 2. dialogo entre o sistema de justica e sistema de saude & $M$ \\
\hline
\end{tabular}

